
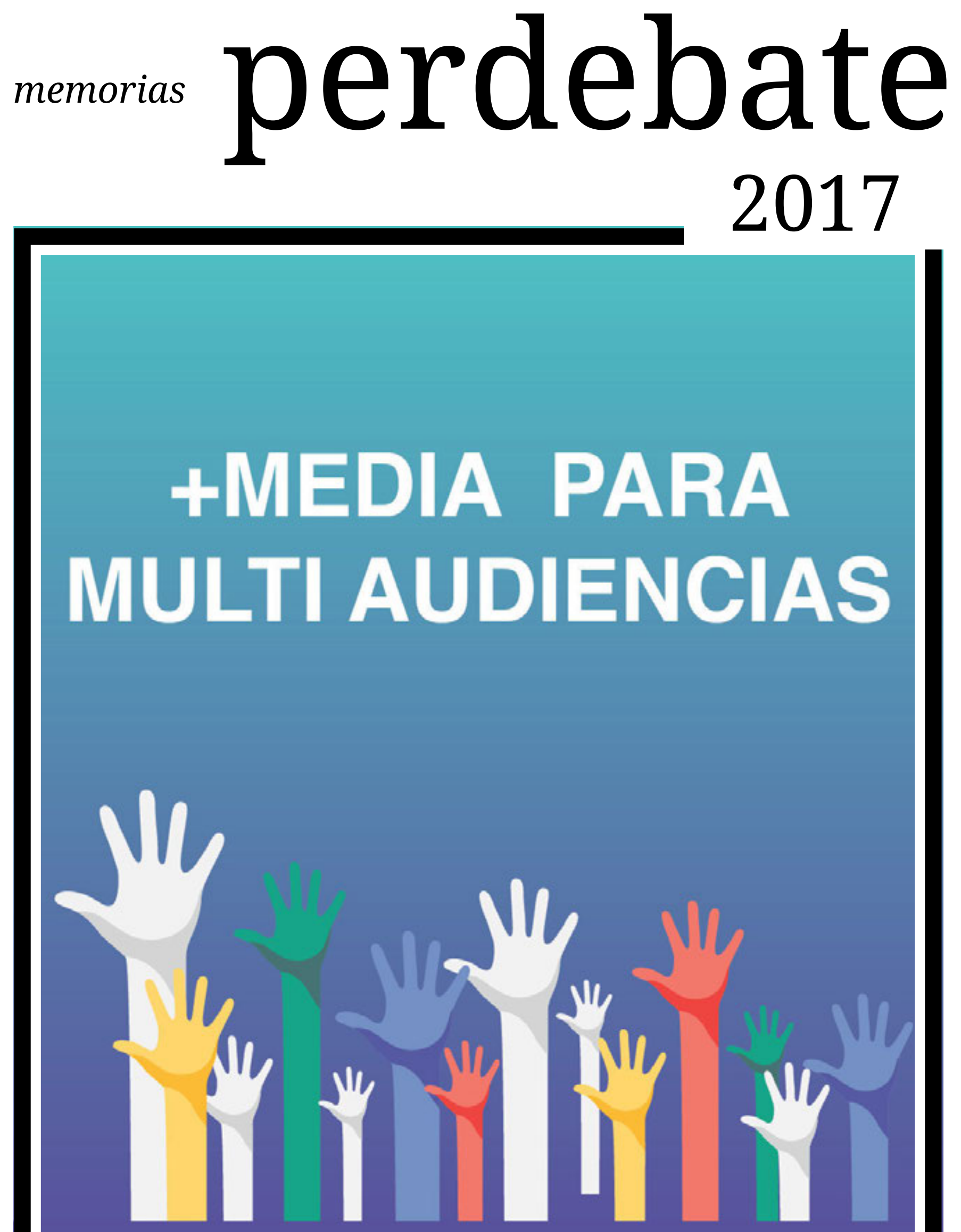

त्रा

$\theta$ i

(2) है,

cococi.

prn

$\mathrm{Us}$ 


\section{Memorias PerDebate 2017}

\section{Editores}

Eric Samson ${ }^{1}$, Tania Orbe ${ }^{2}$

${ }^{1}$ Coordinador de la carrera de Periodismo de la Universidad San Francisco de Quito USFQ.

${ }^{2}$ Docente de la carrera de Periodismo de la Universidad San Francisco de Quito USFQ.

\section{Comité Editorial}

Santiago Castellanos ${ }^{1}$, Gustavo Cusot $^{2}$

${ }^{1}$ Decano del Colegio de Comunicación y Artes Contemporáneas de la Universidad San Francisco de Quito USFQ.

${ }^{2}$ Vicedecano del Colegio de Comunicación y Artes Contemporáneas de la Universidad San Francisco de Quito USFQ.

\section{Expositores}

Cécile Mégie, Susana Morán, Carlos Ponce, Tom Sanderson, Cristoph Geiseler, Toa Maldonado, Bélgica Calderón, Betsi Grabe, Ariel Dulitzky, Mukul Devichand, Nelly Valbuena, Lara Whyte.

\section{USFQ PRESS}

Universidad San Francisco de Quito USFQ.

Campus Cumbayá USFQ, Quito 170901, Ecuador.

Febrero 2019, Quito, Ecuador

Catalogación en la fuente: Biblioteca Universidad San Francisco de Quito USFQ, Quito, Ecuador.

Esta obra es publicada bajo una Licencia Creative Commons Atribución-NoComercial 4.0 Internacional (CC BY-NC 4.0).

Citación recomendada de toda la obra, ejemplo: Samson, E., Orbe, T., (Ed.) (2019) Memorias PerDebate 2017. Archivos Académicos USFQ, 17, 1-185.

Citación recomendada de un resumen, ejemplo: Mégie, C. (2019) Conferencia Magistral: "Visión internacional para contextos locales”. Archivos Académicos USFQ, 17, pp. 4-8. 
Archivos Académicos USFQ

ISSN: 2528-7753

Editora de la Serie: Valentina Bravo

Archivos Académicos USFQ es una serie monográfica multidisciplinaria dedicada a la publicación de actas y memorias de reuniones y eventos académicos. Cada número de Archivos Académicos USFQ es procesado por su propio comité editorial (formado por los editores generales y asociados), en coordinación con la editora de la serie. La periodicidad de la serie es ocasional y es publicada por USFQ PRESS, el departamento editorial de la Universidad San Francisco de Quito USFQ.

Más información sobrela serie monográfica Archivos Académicos USFQ:

http://archivosacademicos.usfq.edu.ec

Contacto:

Universidad San Francisco de Quito, USFQ

Att. Valentina Bravo | Archivos Académicos USFQ

Calle Diego de Robles y Vía Interoceánica

Casilla Postal: 17-1200-841

Quito 170901, Ecuador

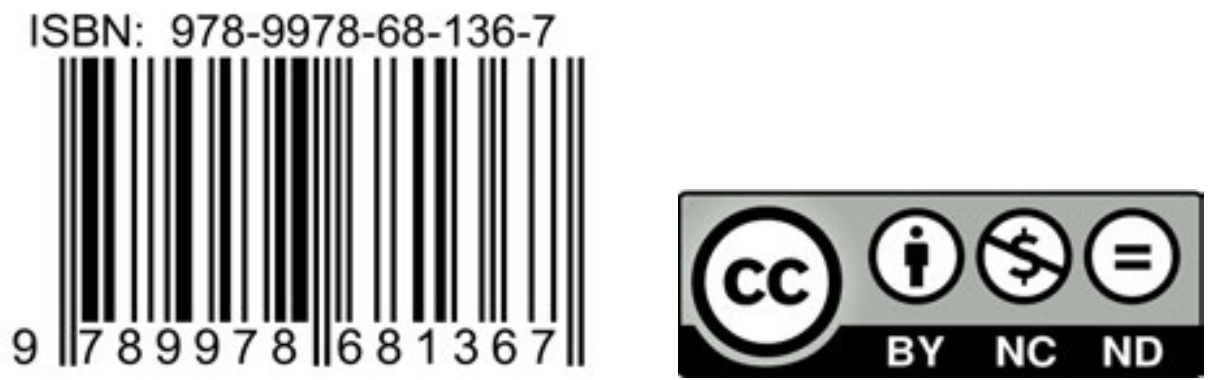




\section{Índice \\ versión en español}

\section{Página 5}

Cécile Mégie - Visión internacional

para contextos locales

\section{Página 10}

Susana Morán - Una comunidad digital

dirigida por mujeres en América Latina

\section{Página 13}

Carlos Ponce - Luces y sombras de la situación real de la libertad de prensa en

América Latina y el mundo

\section{Página 18}

Tom Sanderson - Capacidades de investigación para periodistas que trabajan en comunidades locales

\section{Página 24}

Foro - Periodismo de investigación a toda costa

\section{Página 36}

Cristoph Geiseler - Producción de vídeo en microcuentos virales, una macro tendencia

\section{Página 42}

Toa Maldonado - Producción intercultural de Otavalo

\section{Página 45}

Bélgica Calderón - Los desafíos de la diversidad étnica en los medios públicos

\section{Página 49}

Betsi Grabe - Cobertura de género en los medios

\section{Página 55}

Foro - Investigación académica de género y prácticas de medios

\section{Página 61}

Ariel Dulitzky - Empoderamiento y derechos humanos en las minorías étnicas

\section{Página 63}

Foro - Reto con la diversidad étnica en el mundo del periodismo

\section{Página 68}

Foro - ¿Son inclusivos los medios?

\section{Página 77}

Mukul Devichand - De las redes sociales a las noticias

\section{Página $\mathbf{8 0}$}

Nelly Valbuena - Hablar con / sobre las mujeres: una necesidad urgente

\section{Página 82}

Lara Whyte - Desafíos en la cobertura de los derechos reproductivos y las comunidades LGBTI

\section{Página 86}

Foro - Liderazgo femenino en los medios

\section{English Version}


Memorias PerDebate17

Español

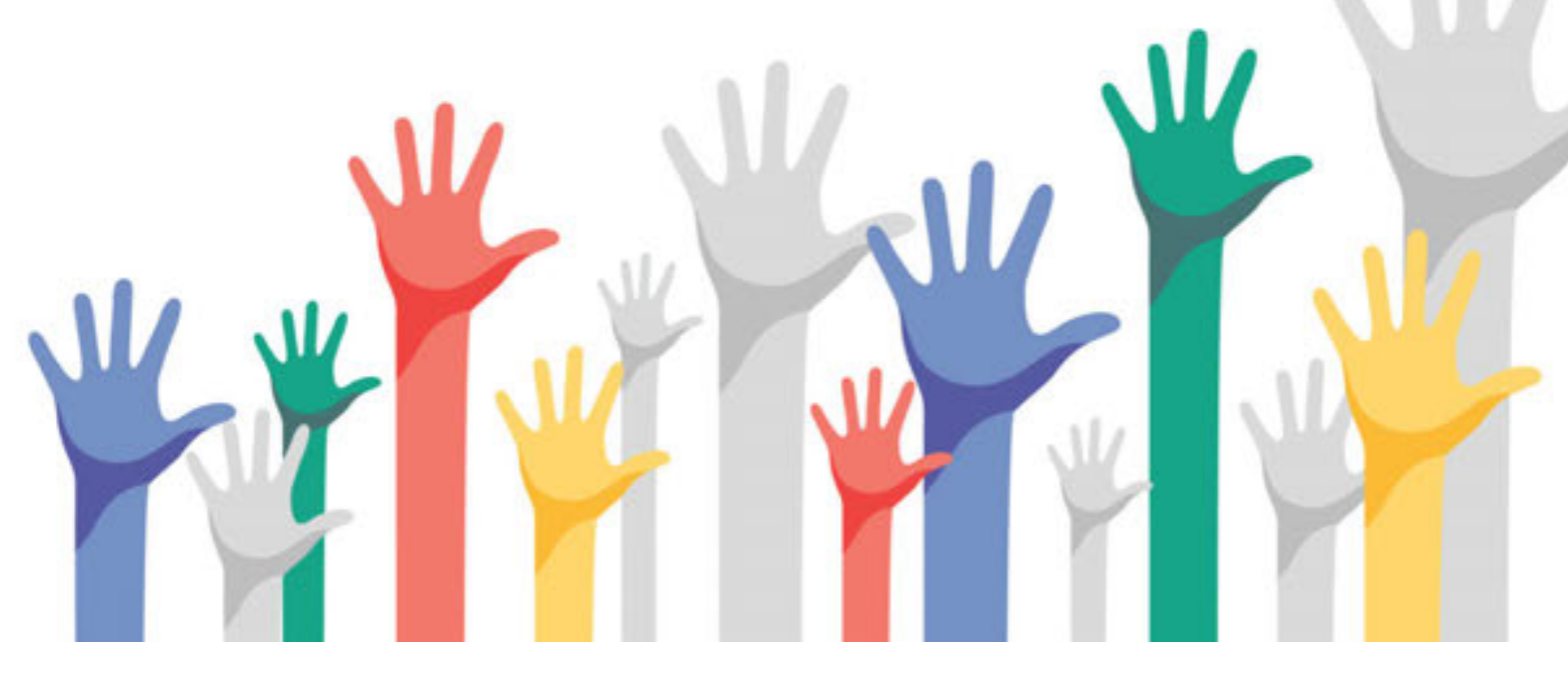




\section{Día 01}

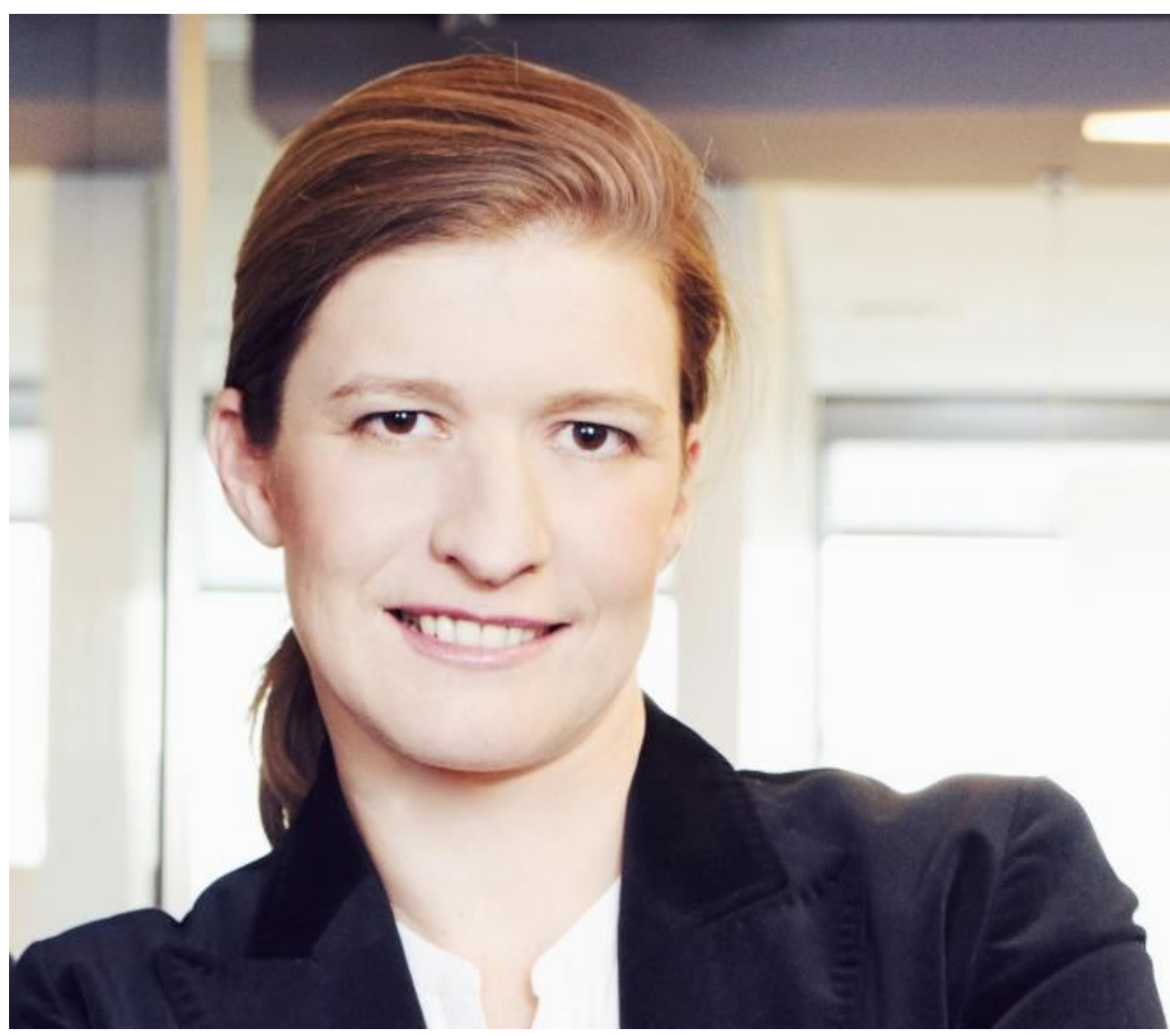


Cécile Mégie,

Directora General de Radio France International

Volver al índice - English Version

\section{Conferencia Magistral: "Visión internacional para contextos locales"}

Cécile Mégie, quien se desempeña hace 5 años como directora general de Radio Francia Internacional (RFI), institución en la que ha trabajado por más de 25 años, agradeció el nvolucramiento y participación de organizadores, embajadas, periodistas y estudiantes, en la realización de la VII edición del Congreso Internacional "Periodismo en Debate". Evento clave y necesario para aprender, saliendo de la rutina.

Un video de corta duración proyectó los miembros y los temas que hacen Radio Francia Internacional (RFI) y, la importancia de escuchar lasvoces del mundo. RFI está hecha en francés, pero también funciona en 13 idiomas internacionales, reconociendo la necesidad de hablar con

\section{RFI ha estado trabajando en español desde 1983. Hay 28 radios que emiten programas RFI en Ecuador y 400 en América Latina.}

sus audiencias en sus propios idiomas. Existen radios internacionales, como la BBC y la Voz de América, que trabajan en muchos otros idiomas en sus programas; RFI trabaja con la estrategia de crear contenidos en nuevos idiomas, especialmente en África. El español es un lenguaje importante para RFI, es un desafío que se ha venido trabajando desde 1983; existen 28 radios que emiten programas de Radio Francia Internacional en Ecuador y 400 en Latinoamérica.

Radio Francia Internacional ha estado transmitiendo por más de 70 años, manteniendo las tendencias y formatos, aproximándose con sus audiencias en África, Haití o en cualquier parte del mundo. 
En la línea editorial de RFI, la información debe ser confiable, verificada, responsable y equilibrada. RFI cree en la importancia de la comprobación de los hechos para que las audiencias puedan confiar en la información que se dice. Un ejemplo de esto fue un país de habla francesa que tenía un programa de noticias con información incorrecta, no verificada; RFI y otras radios controlaban su información. El trabajo del corresponsal es verificar la información que se entrega al público, separar los rumores y centrarse en la información verdadera. $Y$ eso es algo vital en $\mathrm{RFI}$, que tiene más de 156 radios en $\mathrm{FM}$ en 59 países con los que tiene un importante nivel de responsabilidad. Además, transmite en cable satelital y en 579 radios en América Latina y el Caribe, y más de mil en el mundo; en redes sociales, 4 millones de seguidores en Twittery 15 millones en Facebook. RFI cuenta con una audiencia, en FM, que asciende a los 40 millones. seguridad para todos los colaboradores que a veces trabajan en situaciones difíciles como en México, África o Siria, donde los periodistas ponen su vida en riesgo. Afirma que, en la vida de un periodista siempre habrá riesgos, no solo en las zonas de trabajo, sino que en su vida diaria es importante contar con políticas de seguridad en las que los corresponsales puedan sentirse seguros mientras hacen su trabajo. Estos últimos 15 años, RFI tuvo cuatro trabajadores muertos mientras hacían su trabajo. Una en Afganistán, uno de Costa de Marfil y dos cuya muerte se memoriza cada segundo de noviembre como el Día Internacional contra la Impunidad en Contra de los Periodistas.

En RFI existe una persona capacitada para seguir los procedimientos de seguridad y cada vez que se presenta una situación de riesgo, esta persona ayuda al periodista

\section{En París hay 450 periodistas y en todo el mundo más de 400 corresponsales especializados en varios idiomas}

Mégie resalta la vitalidad de RFI como una gran radio con un amplio número de miembros. En París, por ejemplo, hay 450 periodistas y alrededor del mundo más de 400 corresponsales especializados en varios idiomas. El objetivo de RFI es estar cerca de la audiencia en un nivel temático, yendo al campo y trabajando con el idioma nativo. Son los corresponsales quienes deben alimentar la radio y ser capaces de explicar las noticias que circulan en un país a kilómetros de distancia de Francia. El objetivo básico de una radio corresponsal como RFI es que el mundo se interese en diferentes países y encontrar personas en Francia preguntando sobre la situación de América Latina.

Otro tema de importancia para Cécile Mégie, es su responsabilidad como Directora General de la radio donde extrema medidas de porque, agrega, no hay una historia que valga la pena la vida de un periodista. Inmediatamente, se realiza un rastreo extenso cuando un corresponsal se encuentra en un lugar peligroso fuera de las conexiones y contactos. Se trata de un equipo muy organizado que acompaña al corresponsal. Hay periodistas que cuestionan las seguridades dadas, pero para Radio Francia Internacional es necesario que el corresponsal pueda trabajar de manera segura con menos riesgos.

Mégie puntualizó el tema de los medios de comunicación y su impacto en la sociedad. La mayoría de los 400 periodistas que trabajan en París comenzaron con la idea de trabajar en una radio, por lo que para elloses un desafío esta transición a nuevos formatos. 
Las redes sociales, la administración de la comunidad y los nuevos gad gets son ejemplos de lo que RFI está trabajando ahora. El periodismo de datos también es muy importante para adaptarse a los nuevos formatos y captar la atención del público.

Los periodistas están preparados para poder publicar informes, audios, entrevistas y vídeos en diversas plataformas. Además, como la proximidad entre la radio y el público es tan importante, el periodista está preparado para trabajar en diferentes idiomas. En África y Rumanía, la radio ha realizado diferentes trabajos para crear proximidad no solo en el lenguaje, sino en las noticias. También en Camboya, donde cada día hay más problemas de libertad de expresión en los medios, RFI ha estado trabajando allí con otras radios. Lo mismo en Haití, que es el segundo país de habla francesa más importante para RFI.

Radio Francia Internacional es un medio público y recibe dinero del estado. Dinero que se ha utilizado para desarrollar programas en diferentes idiomas. Uno de los elementos claves para mantener independencia del gobierno es que RFI recibe dinero de los impuestos de la gente, por lo que RFI no le debe al gobierno sino a los franceses que pagan ese impuesto. RFlesun medio público, no es un medio estatal que es la voz del gobierno que pasa. En la década de los 50, varios gobiernos intentaron controlar la agenda de los medios públicos, pero RFI siempre mantuvo su independencia. Mégie agregó que el tema de las manifestaciones contra la Ley Laboral en Francia puede ser un tema difícil de explicar en diferentes países. También es difícil aclarar que el hecho de que RFI sea un medio público no lo hace la voz de los gobiernos, puede criticarla como lo hace hoy en día con las manifestaciones.

En países como en China, se considera que la radio debe estar alineada con el gobierno, lo mismo ocurre en algunos países de África donde la emisión de RFI ha sido cortada del aire por nueve meses. Por eso, resulta vital para RFI mantener su independencia.

Ahmed Abba, un periodista de RFI, hace dos años y tres meses está en una cárcel en Camerún y su destino se decidirá el 16 de noviembre, su juicio ha sido cancelado. Él ha sido condenado a 10 años de cárcel, también se considera una sentencia de muerte. Su condena fue dictaminada en una región donde Boko Haram está presente, Abba se contactó con miembros de este grupo terrorista y ahora es acusado de complicidad con este movimiento islámico en África. Su trabajo tiene entrevistas con miembros de Boko Haram y es parte de un trabajo periodístico, hacer contactos y hablar con la gente, por lo que esto no debe ser visto como una prueba de complicidad. RFI defiende a este periodista por más de 2 años para hacer que las personas entiendan que contactarse y hablar con las fuentes no debe ser castigado por la ley.

Mégie concluyó su conferencia subrayando la importancia de los corresponsales y de cómo ellos son los únicos que siempre tienen la verdad, sus editores siempre deben apoyar eso. Además, el corresponsal tiene que saber cómo elegir las historias que se cuentan en la radio porque puede haber sucesos muy locales en algunos países que no tienen una importancia internacional. En momentos de crisis, el papel de RFI es asegurarse de que el periodista mantenga la distancia y esté seguro.

RFI ha sido calificado como el primer o tercer lugar en audiencia en siete países. Muchos gobiernos escuchan lo que se dice en RFI; la responsabilidad del corresponsal es asegurarse de que las fuentes y la información sean verdaderas. Especialmente en momentos de crisis donde los gobiernos están escuchando y el corresponsal tiene que estar seguro. Un ejemplo es Jean Helene, periodista de RFI, asesinado en Costa de Marfil en un estado de preguerra, se creía que Helene se alineó con la posición de Francia durante la guerra y por eso murió. 
La autocensura ha sido necesaria en RFI con la finalidad de asegurar la integridad del corresponsal y de la gente involucrada. Es decir, regular la necesidad de hacer pública cierta información, que por la coyuntura podría generar violencia. La responsabilidad tanto del corresponsal como la del editor es enorme en el momento de la creación de contenidos y noticias que informar en RFI.

\#PerDebate17

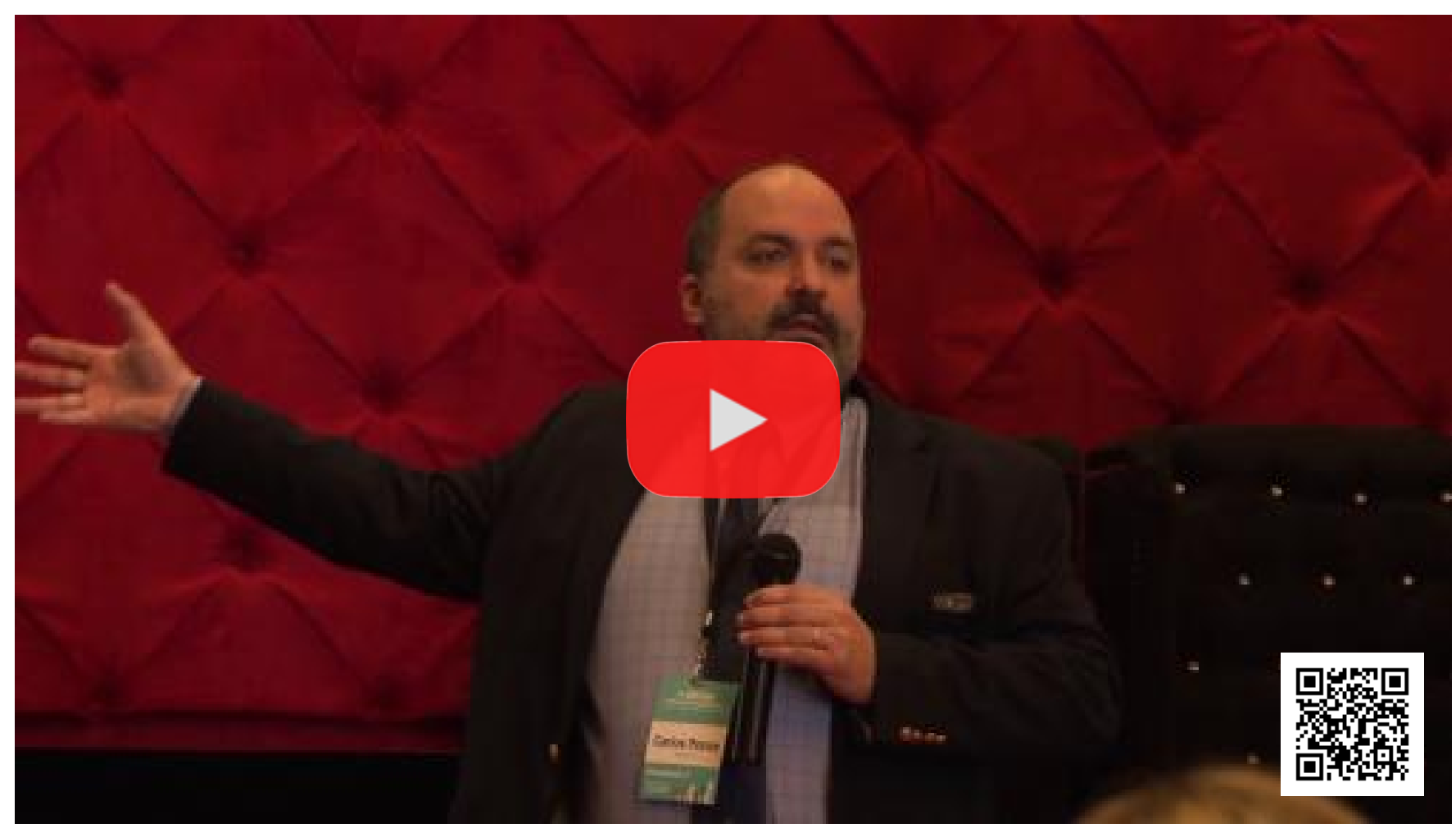




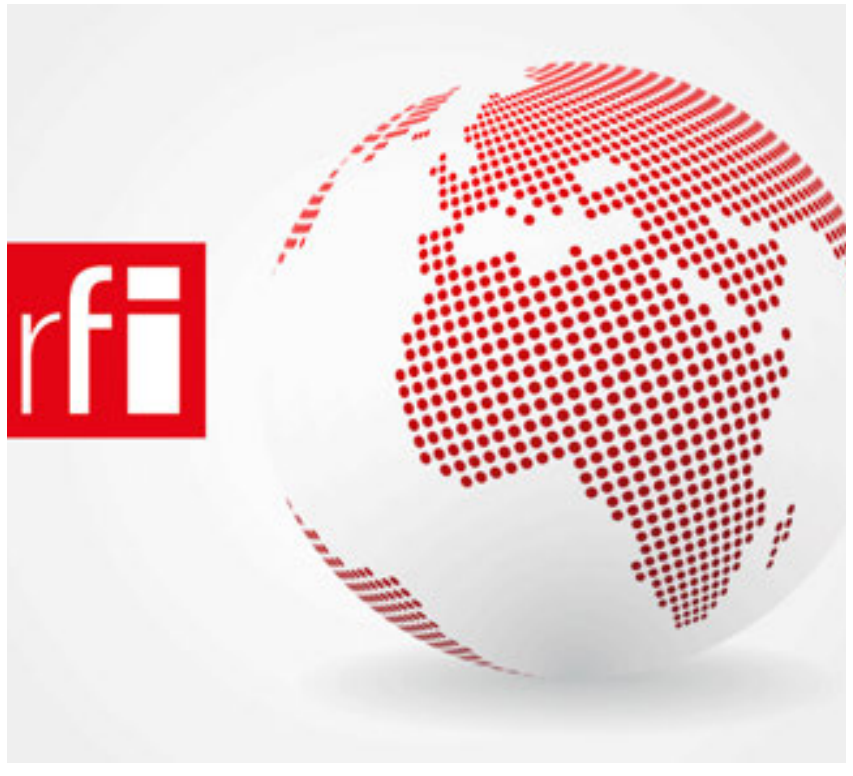

Audiencia internacional

RFI se hace en francés pero

también funciona en 13 idiomas internacionales, ya que reconoce la importancia de hablar con sus audiencias en sus propios idiomas.

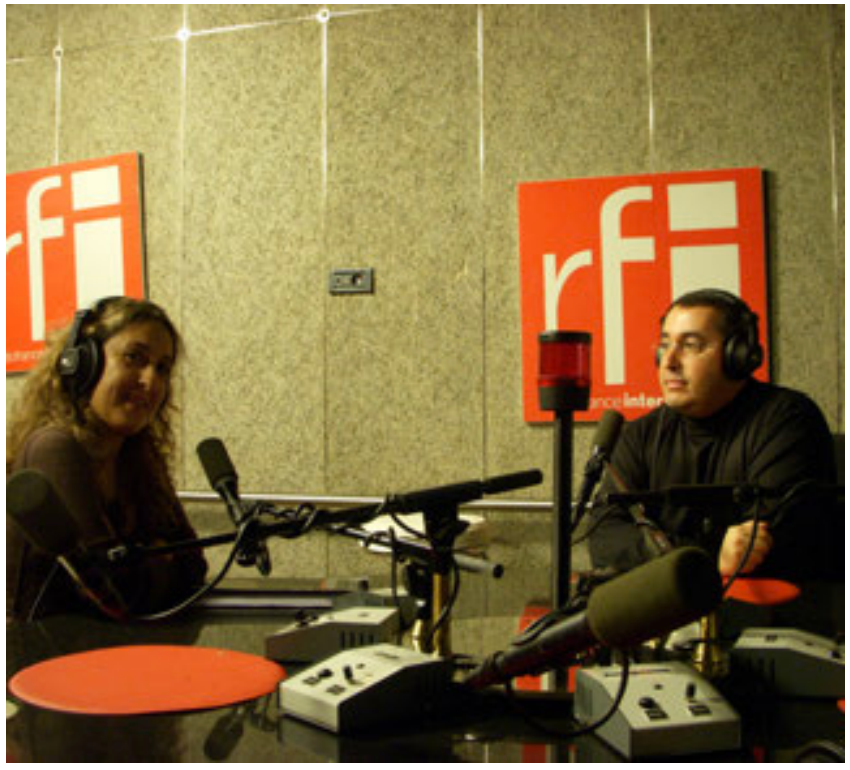

Desafíos para los periodistas

En los últimos tres años, el 60\% de las búsquedas no se realizan en la página web, sino en las redes sociales. La mayoría de los 400 periodistas que trabajan en París comenzaron con la idea de trabajar en una radio, por lo que para ellos es un desafío esta transición a nuevos formatos. 


\section{Susana Morán,}

\section{"Una comunidad digital dirigida por mujeres en América Latina"}

Susana Morán, periodista a cargo de la conferencia, agradeció la oportunidad de participar en este debate, un espacio importante para reflexionar y hablar sobre el periodismo en Ecuador.

La iniciativa Chicas Poderosas comenzó a trabajar en el Ecuador hace algunos meses. Este fue lanzado en septiembre de 2017, se pensaba que era vital llevar esta iniciativa a Ecuador, ya que era uno de los pocos países que no tenían embajadores de las Chicas Poderosas. Morán aclaró tres ideas básicas de lo que representa esta iniciativa.

Primero, es una comunidad internacional de mujeres sin fines de lucro, en 13 países y Ecuador es uno de los cuatro últimos países con esta iniciativa, especialmente periodistas de la región con el objetivo de promover nuevos medios digitales como una oportunidad para hacer un buen periodismo. Con la ayuda de estas nuevas narrativas en el periodismo se generan factores para desarrollarse más y mejorar su contenido. Comenzaron en 2013 con Mariana Santos, la fundadora, diseñadora gráfica, ha trabajado en varios otros proyectos contando historias de eventos internacionales y locales. En 2010 y 2011 comienza a trabajar en la innovación de un periódico. Era un grupo de aproximadamente 180 personas cuando se dio cuenta de que solo había tres mujeres. Es ahí cuando se pregunta qué está pasando, por qué las mujeres están fuera de la conversación de este mundo de la tecnología. Desde entonces ha estado haciendo muchas cosas, una de ellas fundar Las Chicas Poderosas, movimiento que ha estado creciendo en muchos países.

Segundo, la iniciativa Chicas Poderosas tiene una perspectiva de género, quiere que las mujeres se involucren en la tecnología en su vida diaria y en su trabajo.

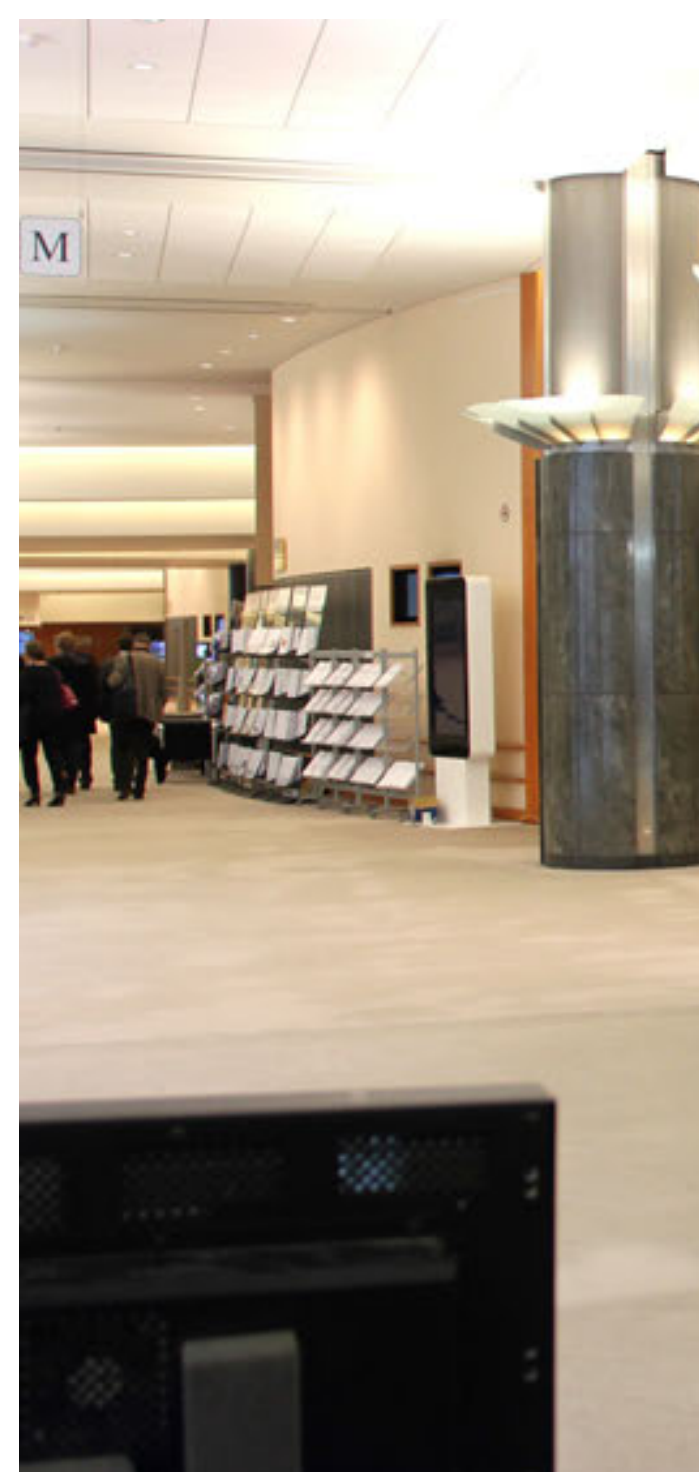




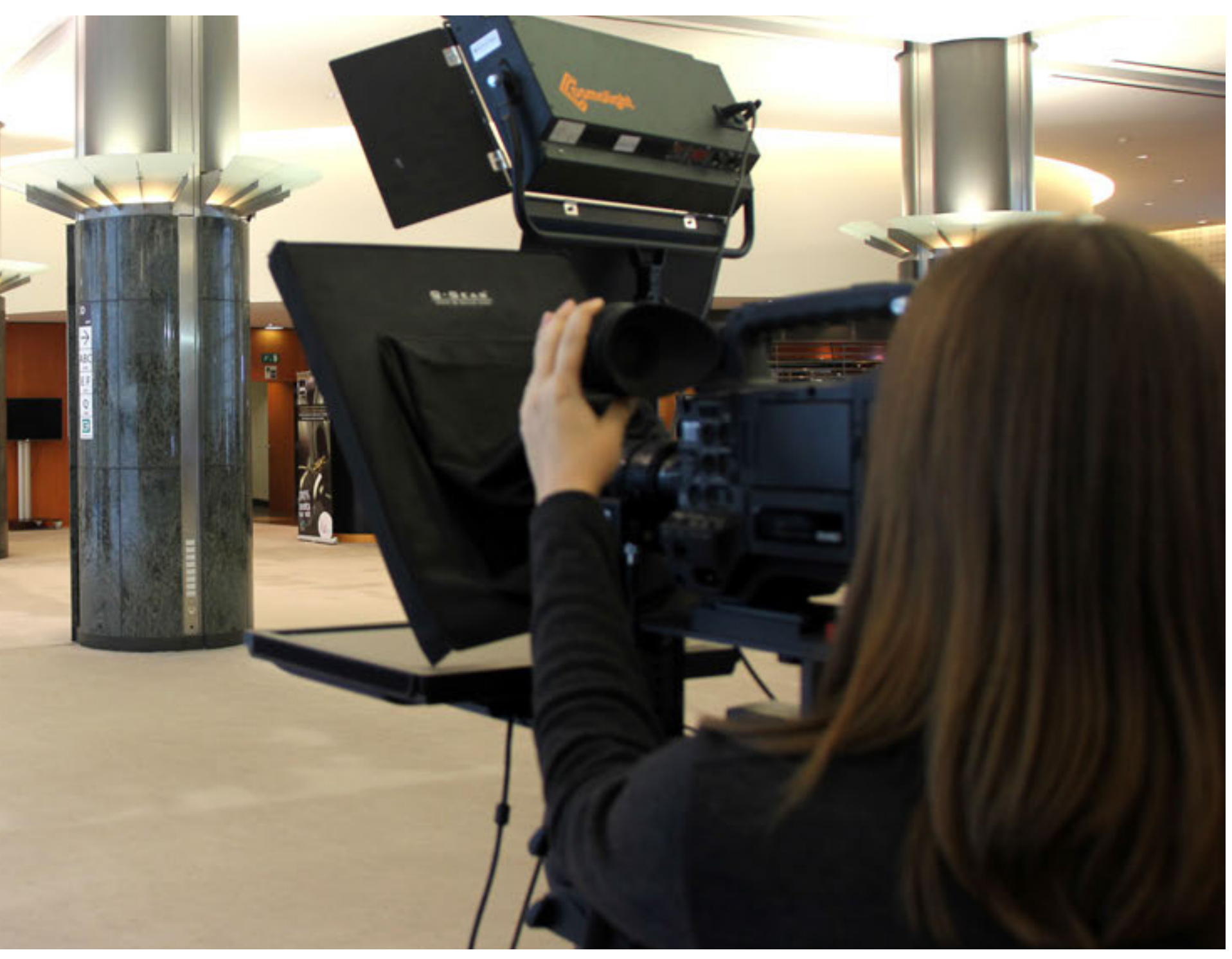


Esta comunidad es muy inclusiva y cualquier persona interesada en ser parte es bienvenida. Son diversas, no solamente hay periodistas, la comunidad está formada por diseñadores, comunicadores, arquitectos, músicos, artistas, matemáticos, economistas, profesionales que quieren contar historias que importan. $Y$ esto es exactamente lo que esta comunidad está buscando, trabajar con diversas personas con el fin de buscar la innovación, como dice Mariana, cosas locas y excepcionales para nuestros países.

Tercero, Chicas Poderosas trabaja específicamente en dos temas principales. La creación de debate con el fin de reflexionar sobre el papel del periodista y lo que se ha hecho para mejorarlo impartiendo talleres y conferencias para la comunidad involucrada. Hablar de experiencias y tratar de tener los mejores talentos en los mejores lugares para crear proyectos y cosas nuevas.

En el lanzamiento de la iniciativa Chicas Poderosas en Ecuador, fueron invitadas mujeres que están liderando diferentes proyectos. Una de ellas, Carolina Mela, que trabaja en la investigación de la realidad virtual en España. Ella habló sobre su experiencia en nuevas tecnologías y su trabajo, y cómo Ecuador aún necesita lugares de trabajo para desarrollar estas nuevas narrativas con el periodismo. Chicas Poderosas decidió comenzar talleres para hablar sobre la realidad virtual como una manera de contar historias sobre derechos sexuales y reproductivos. Estas nuevas formas de periodismo usando nuevas herramientas de tecnología son lo base de Chicas Poderosas.

Susana Morán expuso tres proyectos importantes que se están realizando en América Latina. Proyectos que han crecido con sinergia conociendo a las personas exactas en el momento exacto. Ese es el espíritu de Chicas Poderosas crear estos proyectos para mejorar el periodismo y hablar sobre los problemas que afectan a las mujeres y de los que nadie más habla, como la violencia de género.

En la página web, hay un artículo llamado "Historias de Femicidio". Este proyecto se inició en México con CONNECTAS, un grupo de periodistas que apoyan la investigación. Junto a la iniciativa Chicas Poderosas, en México, comenzaron a leer la prensa amarilla y toda esta información la clasificaron, cada ataque a una mujer se convirtió en datos para ellos, clasifican la información por edad, ubicación, qué tipo de crimen fue cometido y si los asesinos tenían alguna relación con la víctima. Todo esto se convirtió en una enorme base de datos que ha sido reconocida internacionalmente. En Ecuador, Geografía Crítica, un grupo de mujeres geógrafos, están desarrollando la misma idea con el fin de tener estadísticas locales de femicidios. Se ha logrado obtener estadísticas más rápido que las obtenidas por entidades gubernamentales a cargo de crímenes.

Se realizó un proyecto en el que las Chicas Poderosas están trabajando actualmente, un acelerador de medios impulsado por mujeres. Es algo muy nuevo en la región, ya que comenzó en Brasil en octubre. La idea de este proyecto es que las mujeres estén en puestos de liderazgo en periodismo. Es un taller de 5 meses y se impartirá todos los años y no importa el país es el patrocinador del programa, se puede participar en todos los países y en todos los proyectos. Todo hecho con la idea de promover el periodismo independiente.

Morán finalizó su conferencia con algunas estadísticas importantes de mujeres en los medios. Sembra Media realizó una investigación importante, liderada por una mujer, donde identificó que, en un centenar de medios digitales en cuatro países de la región, el $60 \%$ de ellos, las mujeres formaban parte de nuevos proyectos y el $40 \%$ de esos proyectos eran liderados por mujeres. 
Carlos Ponce,

Director en Freedom House de América Latina

Volver al índice - English Version.

\section{Conferencia Magistral: "Luces y sombras de la situación real de la libertad de prensa en América Latina y el mundo"}

Freedom House es una organización que durante más de 75 años ha promovido diferentes libertades, los derechos humanos, la libertad de prensa, la asociación, la expresión y la libertad religiosa. Esta organización fue creada por un grupo de personas con Eleanor Roosevelt por las Naciones Unidas para prevenir las desgracias acaecidas en el siglo pasado, manteniendo libertad y respeto. Así, la organización fue creada para promover la declaración universal y más tarde para convertirse en un centro de intercambio de ideas para materializar la democracia en diferentes regiones e impulsar estrategias que puedan conducir a una mayor libertad.

Ponce, director regional de América Latina y el Caribe para los programas de Freedom House, explicó que la estructura

Freedom House es una organización que durante más de 75 años ha promovido diferentes libertades como los derechos humanos, la libertad de prensa, etc.

de la organización es híbrida, a diferencia de otras organizaciones de derechos humanos. Libertad de Prensa tiene otros roles. En primer lugar, trabaja directamente con asociaciones de periodistas en Venezuela o Cuba, en países con una sociedad muy cerrada como Irán, Zimbabue o grupos de vulnerabilidad en diferentes países como en México, Guatemala, Honduras, El Salvador o con los escuadrones de la muerte de Nicaragua, Paraguay, Ecuador, Venezuela y Colombia. La otra parte es la incidencia con el congreso en Estados Unidos, la OEA y otros países para promover cambios interesantes y en prensa. 
Las organizaciones tienen clasificaciones y calificaciones, su informe Libertad en el Mundo tiene 50 años y es la categoría más antigua para medir al Estado y la democracia a nivel mundial. Libertad de Prensa tiene 38 años y a pesar de otros rankings más antiguos, es bien conocido y utilizado principalmente. Libertad en la Red tiene 5 años. Mucha gente se pregunta cuál es el uso de estas calificaciones. La mayoría de las veces, los gobiernos autoritarios se preocupan por lo que piensa la gente $y$, por otro lado, la mayoría de nuestros rankings, al menos la Libertad del Mundo y la Libertad de Prensa, son utilizados por las agencias calificadoras de riesgo para evaluar la capacidad de un país para cooperar. Los fondos del milenio de los Estados Unidos normalmente solicitan a Libertad de Prensa su clasificación para decidir si desean o no dar recursos a un país. Cuando el Banco Mundial decide otorgar un préstamo, la decisión se basa en los rankings de ellos.

Por lo tanto, la clasificación tiene impacto. Por ejemplo, cuando se marca la región de México, Venezuela, Nicaragua, Cuba como países no libres, eso genera un impacto. Pero también tiene un impacto en la obra de muchos periodistas y blogueros, ya que caían en cuenta que están viviendo una percusión que está siendo mostrado por alguien fuera del país, es decir que es de atención internacional saber lo que está pasando con un periodista torturado o desaparecido, en diferentes países. A veces la percusión del periodista es más costosa porque al final los créditos que el país busca son más caros.

Es un informe que cuenta con la colaboración de expertos nacionales para hacer una calificación mundial. En la presentación, Ponce mostró que había pocos países, pero también dijo Libertad de Prensa no es la única, ya que Human Rights Watch o Reporteros sin Fronteras han hecho lo mismo. De todos modos, la parte interesante de todas estas organizaciones es que han llegado a la misma problemática en países sin libertad. Como la misma conclusión de que México es un país de riesgo para los periodistas y blogueros, sociedad civil, siendo la justicia la herramienta de persecución. Ponce mostró la similitud en Zimbabue, Corea del Norte, informes similares $y$ el autoritarismo como modelo de gobierno, violando derechos de libertad.

Libertad de Prensa también analiza el autoritarismo y los desafíos que tienen los países cuando pierden la libertad. Una idea interesante es que en cuanto más autoritario el país, más necesidad ha tenido el gobierno de perseguir a los periodistas que buscan la verdad. Nadie quiere un periodista que investigue sobre violaciones de derechos humanos, nadie quiere que un bloguero informe sobre desapariciones 0 sobre corrupción. El periodismo es perseguido en la mayoría de países, incluso en los Estados Unidos, un país supuestamente seguro para los periodistas. Todos los países donde el gobierno ha perseguido a los periodistas intentan limitar la libertad de expresión, pretenden controlar todos los medios; la misma conducta puede ser vista en los gobiernos de América Latina donde los gobiernos han decidido tomar posesión de los medios de comunicación directamente. Venezuela con Hugo Chávez, Nicaragua con Daniel Ortega, Rafael Correa en Ecuador. Controlar el periodismo, controlar los medios para autocensurarlos es una forma de controlar la expresión en los países, especialmente en aquellos que yahan sufrido antes estos estados de represión constantes.

Ponce explicó que en algunos momentos históricos hay varios momentos comparables dentro del tiempo en que se puede ver la variedad de la libertad. En 1996, muchos países querían vivir en democracia, después del rompimiento de la URSS. En América Latina, más gobiernos quedaron fuera del control militar. En los años previos 1986 se había ejercido mucho control en la libertad y la prensa. Desde 2006 y 2016 podemos ver que la libertad está volviendo a reducirse, hay más persecución y más acoso. 
Del 38\% de los países libres se redujo al 31\%, es decir que la mayoría de los países han pasado al estado de libertad parcial.

Otro dato clave fue la libertad de la prensa en Latinoamérica y se demostró que Costa Rica es el país con mayoresíndices de libertad, seguido por Uruguay, Chile, El Salvador, República Dominicana, Perú, Argentina y Brasil. En cambio, los peores países de la región son Cuba, Venezuela, Ecuador, Honduras y México. La calificación puede ser más segmentada y mostrar las categorías en que los países califican. Por ejemplo, en México es posible calificar la libertad de prensa, el número de asesinatos de periodistas no solo por entidades gubernamentales sino también por empresas. También en Honduras, donde ser periodista es un gran riesgo. Y hasta 2016, ser periodista en Ecuador también era un riesgo; la persecución, las leyes, el control, son algunos factores de la clasificación. Además, Venezuela con el cierre buenos periodistas se acostumbran a demandas, juicios y amenazas. Él, por ejemplo, no es bienvenido en Venezuela, Nicaragua y Cuba. Lo interesante de esto es que una demanda en Nicaragua no importa, ahora Nicaragua lo demandó en Washington, para empezar a perseguirlo internacionalmente. $Y$ el problema es que se convierte en un gran juicio que impide trabajar y desarrollar el proceso de una manera correcta.

Ponce dio a conocer más calificaciones que se encuentran en la página web, la intimidación policial, la compra de medios por parte de los gobiernos o testaferros, la restricción a la fuente de información, incluso en Estados Unidos. El uso de la prensa, las redes sociales, los trolls para desacreditar el trabajo periodístico y controlar qué o qué no publicar. Otra categoría importante es el espionaje de periodistas que ha comenzado a aumentar en más países, cómo el gobierno espía a un periodista y usa su información privada para

\section{La libertad de prensa encontrada es que cuanto más autoritario es el país, más necesidad ha tenido el gobierno de perseguir a los periodistas}

de medios internacionales y locales, así como blogs y Twitter, Cuba sin libertad en absoluto. Ahora, ¿cuáles son los desafíos para la libertad de prensa? Primero, si hay impunidad en un país, aun cuando modifiquen algunas entidades, si el sistema de justicia no investiga las amenazas, la corrupción y la denuncia de los periodistas, la impunidad constituirá un problema real, ya que es una de las principales limitaciones en el ejercicio de la democracia. En todos los países, vemos que a menos libertad más centros regulatorios se han creado para el control de los medios de comunicación, para sancionar a periodistas, persiguiendo y creando un ambiente de limitación. El uso del mecanismo de justicia para perseguir periodistas como amenazas y juicios. Ponce considera que los censurar. Por ejemplo, la censura de medios sociales y académicos en China, que ha hecho que Cambridge University Press no publique lo que se considera hable mal del país. Ponce tuvo la oportunidad de hablar con el actor estadounidense Richard Gere, dijo que para él era imposible estar en una película comercial debido al bloqueo que China le dio por su trabajo en el Tíbet. En el episodio de House of Cards, serie estadounidense de televisión web, donde se mencionaba a China, solo se transmitía una vez y tenía que ser modificado. No solo persigue la opinión a nivel local, sino nivel mundial.

Una gran cantidad de gobiernos se excusan argumentando que están protegiendo a los 
periodistas, pero este tipo de mecanismos tan solo promueven la corrupción. Como Freedom House se tienen que crear programas de protección, como en México o Brasil. Estos sistemas eran buenos, pero luego se dieron cuenta que el periodista está solo en esta batalla, porque el mecanismo creado solo proyecta una buena imagen de los gobiernos, pero si no están luchando verdaderamente contra la impunidad, no hay nada que evite la inseguridad. El momento de proteger al periodista es el momento en que comienzan a ser amenazados o el momento en que la libertad se va de ese país. No importa si toda la seguridad existe, si hay impunidad, como en Malta, una bomba mata a un periodista que había estado buscando a la corrupción en los gobiernos.

Este año, Libertad de Prensa también publicó La libertad de la Red con el fin de estudiar los trolls, medios de comunicación represivos con los blogueros, y la forma en que evitan que la gente use Internet. Simplemente no permiten que el bloguero trabaje libremente, los gobiernos están desarrollando leyes supuestamente para controlar la decencia en las redes sociales que simplemente se hacen para permitir que las personas usen libremente Internet. Falsa información y verificación de la información, todos están en Internet y los gobiernos se excusan controlando a los proveedores para que limpien toda la información falsa mientras controlan nuestro derecho a usar Internet.

Los principales desafíos en América Latina, según lo explicado por Ponce, son la neutralidad en la red. Los gobiernos ven como una amenaza para las personas tener acceso completo a la red, el resultado es que las grandes empresas como Google están trabajando con los gobiernos para limitar la libertad de expresión.

Ponce invitó a visitar la página web y ver los rankings. Él piensa que este es un trabajo interminable porque a medida que un gobierno autoritario abandona el lugar, se está fortificando otro en otros países. Es difícil ver mejoras, pero es importante seguir trabajando. Si no fuera por los periodistas, el bloguero, los comunicadores que trabajan contra la corrupción los Papeles de Panamá, Odebrecht, todo sería imposible de descubrir a causa de la corrupción en los gobiernos. Los periodistas han creado mapas y una red global para defender la libertad. Por lo tanto, el último mensaje es que aun cuando haya dificultades en el trabajo periodístico, ya sean por los desafíos y las limitaciones, vale la pena arriesgarse y asumir esos desafíos. 


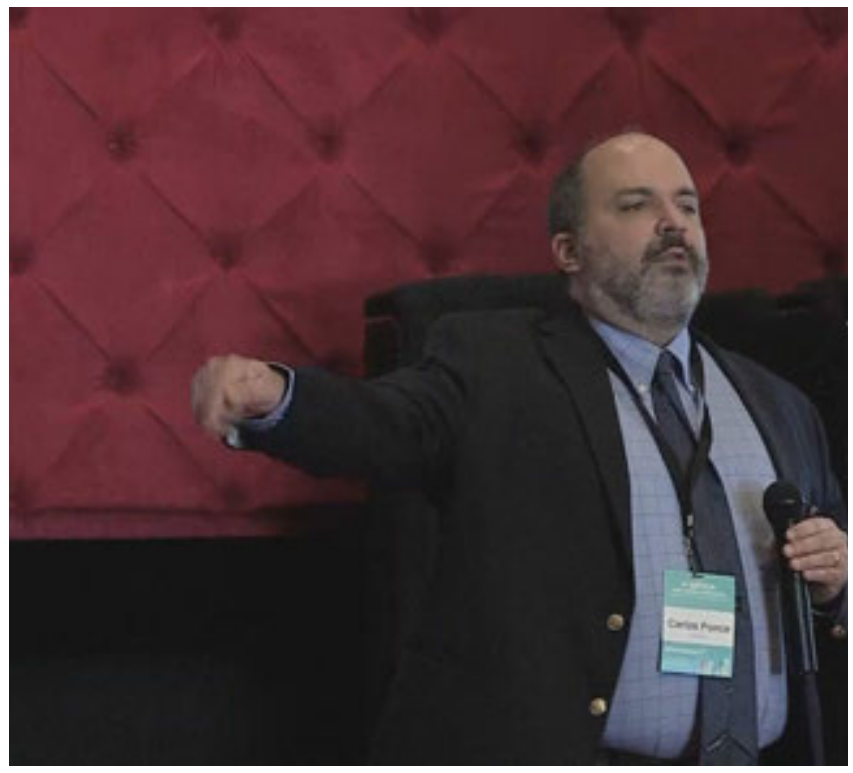

Carlos Ponce

Director en Freedom House de América Latina en su conferencia en PerDebate17.

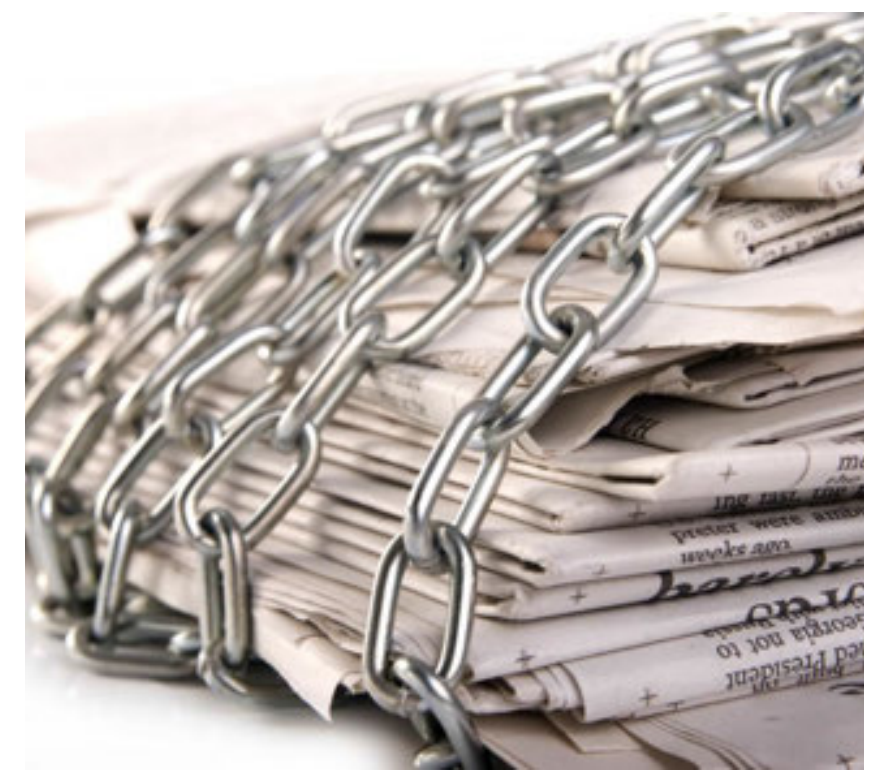

Freedom House

Realiza investigaciones $y$

promueve la democracia, la

libertad política y los derechos

humanos. Se describe como "una

voz clara para la democracia y la libertad para el mundo". 
Tom Sanderson (Reino Unido),

Centro de Investigación en Periodismo (CIJ)

Volver al índice - English Version.

\section{Conferencia Magistral: "Capacidades de investigación para periodistas que trabajan en comunidades locales"}

Tom Sanderson, representante del Centro de Investigación en Londres. El CIJ es una organización benéfica educativa que enseña habilidades prácticas de investigación a periodistas; durante los últimos 506 años ha enseñado también a sindicatos, activistas, abogados.

Hay que entender la práctica periodística como un llamado a servir; el periodismo como un servicio público sin control y regulación del gobierno, sino más sobre las personas, un ejemplo conflictivo de ello, Ecuador y las enmiendas a las comunicaciones, diciembre, 2015. Sanderson, explica que el público nunca es un grupo de personas claramente definido y el interés del público puede diferir ampliamente. Sin embargo, el interés público hace servir a un punto de referencia como tal.

En el Reino Unido existe una definición legal de interés público "que incluye, proteger la salud y seguridad pública y evitar que el público sea engañado por una declaración de una organización o individuo. Pero ni siquiera esa definición es definitiva, de hecho, David Lee, un importante periodista de investigación y amigo a largo plazo del CJI, agrega que "la información es de interés público para que cese la función propia de una democracia". Esta definición puede entrar en debate cuando se pregunta qué es la democracia y cómo podemos decir si funciona correctamente, esto debate para llegar a la respuesta, la pregunta sobre cuál es el interés público. Pero, ¿qué pasa con el periodismo, qué queremos decir realmente cuando usamos el término periodismo? Entonces, en las citas clásicas de George Orwell, "el periodismo está imprimiendo lo que alguien más no quiere imprimir, todo lo demás son relaciones públicas", pero esa es una definición bastante restrictiva. Excluye otra característica de la historia de interés humano comola escritura de viajes que mucha gente verá como periodismo. 


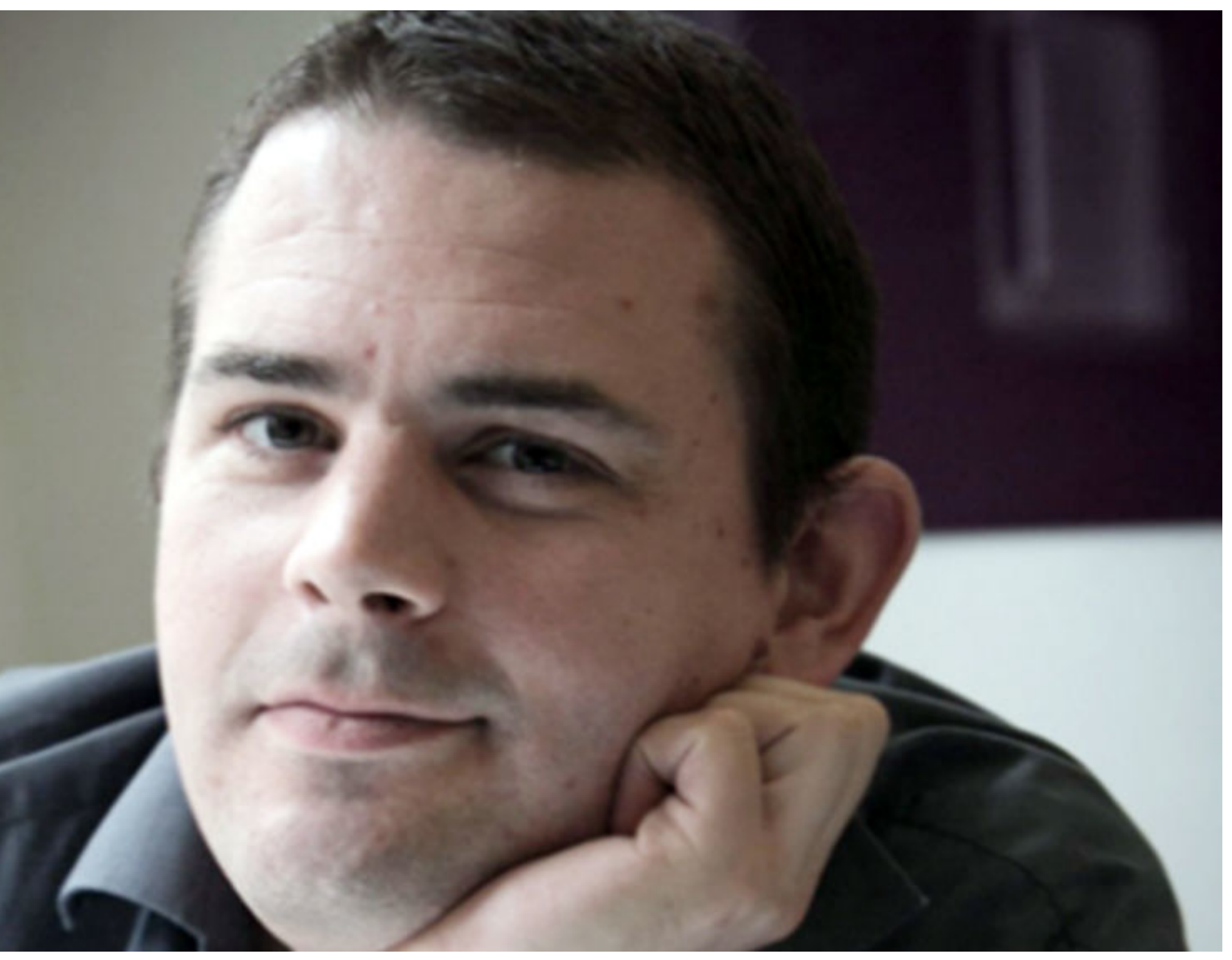


Más allá de los recursos de tiempo, la importancia del periodismo de investigación se nutre de su independencia. Sin independencia no imprimirás lo que otros no quieren que imprimas y sin eso, según Orwellalmenos, seestará haciendorelaciones públicas. Pero ¿qué hacemos los hombres cuando decimosindependencia? La definición principal es una pregunta que debe plantearse. Entonces, hay diferentes tipos de independencia, correspondientemente, sus actores que los periodistas necesitan para asegurar y asegurar su forma de independencia. Entonces, la independencia política, el gobierno, la independencia editorial y la independencia financiera forman anunciantes y propietarios; eso se desarrolla de diferentes maneras, en diferentes contextos, Sanderson explicó algunos ejemplos para comprender cómo algunos de estos intereses han comprometido a periodistas y organizaciones.

En primer lugar, en febrero de 2015, Peter Oborne, que era el principal comentarista político del diario The Telegraph, renunció públicamente. Por lo tanto, a Oborne le preocupaba la independencia del documento a lo largo de un general que declinaba la calidad y los valores. Él ya había aceptado renunciar, pero se iba a ir tranquilamente al final de su contrato. Su decisión de hacer públicas sus razones para su renuncia se debió al paquete de cobertura de The Telegraph para la investigación de archivos del ICIG, lo que lo hizo tomar una decisión adelantada.

Esta investigación mostró que un banco reconocido en Inglaterra manipuló algunos mercados financieros y la complicidad en la evasión fiscal. Todos los periódicos internacionales publican esa historia en primera plana, peroThe Telegraph, publicitada por este banco, habla muy poco al respecto. El propio Oborne dijo: "necesitas un microscopio para encontrar la cobertura de The Telegraphs". Oborne continuó diciendo, "si los periódicos importantes permiten que las corporaciones interfieran en nuestro contenido y teman perder publicidad, la democracia misma está en peligro". Entonces ese es un ejemplo de interés corporativo, que ejerce interés en documentos, líneas editoriales.

El siguiente ejemplo muestra el potencial de interés político para el periodista comprometido con su independencia. En marzo de este año, George Osborne, quien recientemente fue nombrado canciller, es decir, la persona que está detrás del Primer Ministro, renunció. Anunció que se convertiría en editor de The Evening Standard, un periódico leído por millones de londinenses. Por lo tanto, el control editorial de este documento tiene una influencia significativa sobre los límites y la dirección del debate público. Pero tomar la dirección editorial de un periódico de Londres mientras todavía servía como miembro del parlamento y supuestamente trabajando para representar a la población en el noroeste de Inglaterra causó mucha desaprobación pública. Sin embargo, el principal problema fue la idea de que una persona con una afiliación política tan clara debería tener influencia sobre una fuente importante de información.

Estos son algunos ejemplos de interés de la prensa escrita, pero ¿qué pasa con las noticias locales? Si tiene alguno de este problema, entre en este contexto. Durante la última década, el Reino Unido ha visto una disminución en el significado del periodismo local debido a la pluralidad de propiedad y los recursos que tienen los periodistas. Hemos estado en muchos ejemplos de activos que se escapan de los periódicos locales realmente estables de una de las cinco compañías que ahora posee más del $50 \%$ de la prensa local en el Reino Unido. En el sitio correspondiente, las autoridades locales han gastado dinero en actividades de relaciones públicas. Por lo tanto, la estabilidad de la prensa local mantiene la cuenta de poder para la decisión tomada en las comunidades locales, ha llevado a una creciente presión del tiempo de los periodistas locales. 
Esto ha reforzado el fenómeno del periodismo que Nick Davies identificó en su libro. Davies dice que el periodista tiene poco tiempo para verificar hechos o cuestionar las cuentas oficiales. Y pudimos ver más y más artículos de prensa con mayor probabilidad de ser un copy-paste de PR. Entonces, las consecuencias de esto para el correcto funcionamiento de una democracia deben ser aclaradas. Pero, ¿cuáles son las consecuencias reales para las comunidades locales? Un ejemplo sorprendente es el desastre, antes de este año, de la Torre Grenfell en junio, un incendio declarado en una casa en una manzana del centro de Londres y las autoridades locales descuidan las normas de seguridad contra incendios debido a la falta de sistemas de aspersión, el fuego se propagó rápidamente y tomó el vida de 71 residentes.

Pero lo realmente trágico es que estos problemas con este bloque en particular ya episodio de Grenfell demostró que los medios están cómodamente con poca conciencia, contacto o conexión en las pistas" y dijo que Gran Bretaña no está sola en esto, que muchas otras sociedades están rotas. La razón principal por la que John identifica es la falta de diversidad de trabajos en el periodismo. El $7 \%$ de la población del Reino Unido tiene educación privada, pero en los medios de comunicación más de la mitad de los principales periodistas del país fueron a la educación privada en la universidad.

Tom Sanderson argumenta que discutirá con John explicando que este no es el único factor. Un gran factor en su opinión, es el declive del periodismo local. De hecho, los periodistas locales formales cuando se les preguntó si habrían publicado el artículo de Grenfell en los años 90 dijeron: "Cien por ciento sí, habríamos elegido eso, si

\section{"... Hay diferentes tipos de independencia, en \\ consecuencia, los actores que los periodistas necesitan para garantizar y garantizar su independencia".}

habían sido informados por un grupo de campaña local. Por lo tanto, esta publicación es de noviembre de 2016 y resalta la organización de supervisión descuidada de ese bloque en particular. Incluso afirma que "es algo verdaderamente aterrador que creemos que solo un evento catastrófico expondrá la ineptitud e incompetencia de nuestro arrendador". Por lo tanto, se comprobó tristemente que la gente comenzó a darse cuenta pero seis meses después, 71 vidas, ya era demasiado tarde.

Entonces, ¿cuál fue la respuesta? La prensa sí tomó nota y memorizó muchos artículos de seguridad contra incendios en bloques similares en todo el país. Además, muchos periodistas comenzaron a buscar respuestas y explicaron cómo el problema debería haberse tomado en serio antes del incendio. Entonces, en un discurso en agosto, un periodista llamado John Snow dijo: "El nubieramos encontrado la nistoria antes que otros medios, nuestro editor tendría nos dijo que no estamos haciendo nuestro trabajo correctamente". Entonces, siento que esto muestra claramente cómo se rompe el sistema en el Reino Unido. En el pasado, la preocupación inicial se elevó a un periodista local que no solo cubría a la comunidad, sino que era parte de esa comunidad y esto debería haber continuado como una cadena que convierte el importante problema de la comunidad en un periódico nacional, y Sanderson explica que este sistema fue perfecto o que siempre funcionará de esa manera, pero ahora parece que funciona así en todo el mundo.

Parece que se ha roto un vínculo crucial entre nuestras comunidades y los medios noticiosos locales. Pero hay algunas razones de esperanza, hay personas para construir 


\section{Bristol Cable}

Un buen ejemplo de esto es el trabajo de Bristol Cable. Un medio que trabaja localmente para Bristol pero que también tiene relevancia nacional y transnacional. Distribuyen 30 mil copias en Bristol, pero la organización trabaja en una base de miembros, donde la gente pagay tiene voz en la decisión de las líneas editoriales y de la tienda en general.
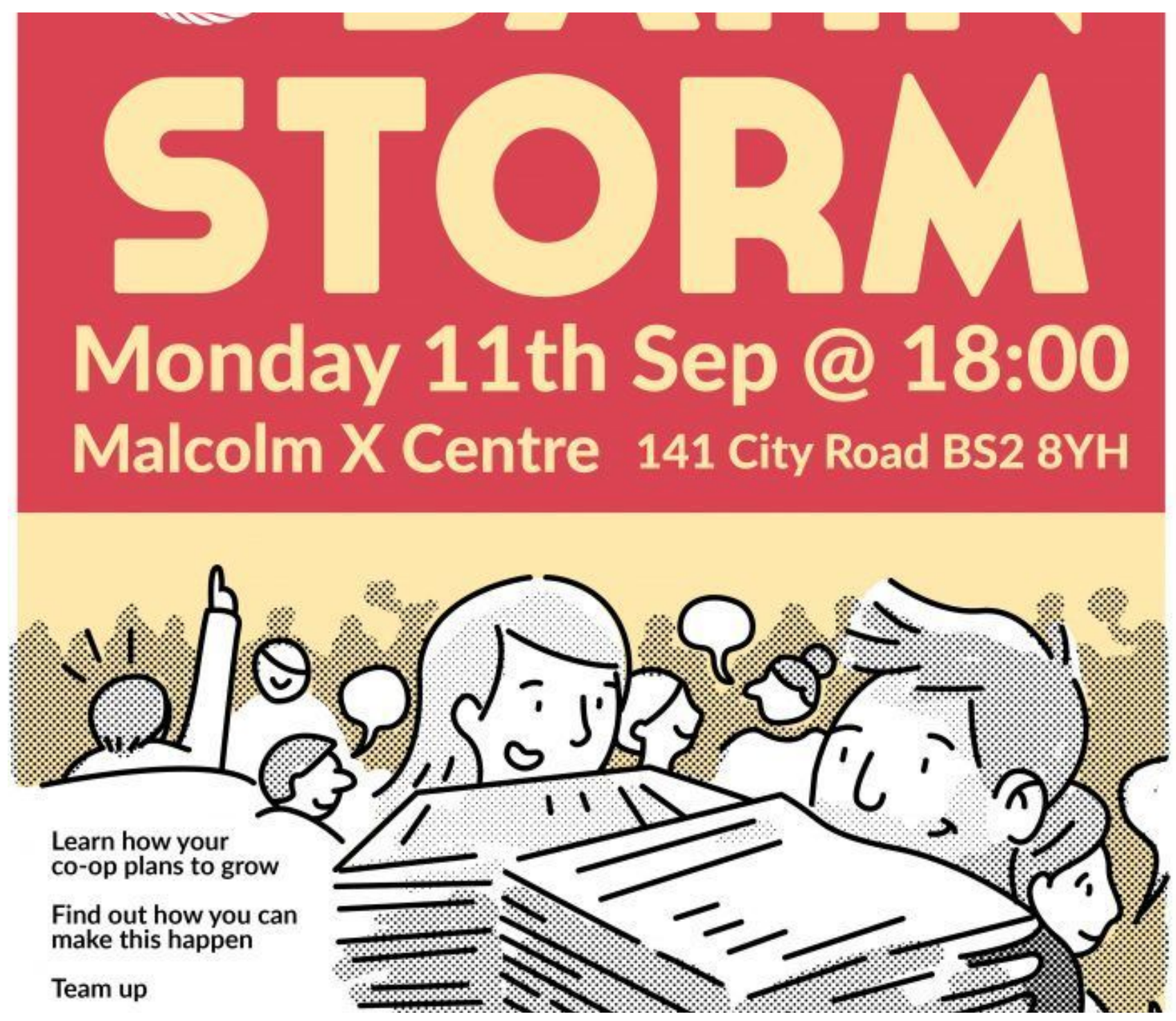

noticias locales, de una manera diferente, no como tratando de capturar publicidad, sino trabajando como una estructura para tener a las comunidades como el corazón del informe.

Un buen ejemplo de esto es el trabajo de Bristol Cable. Un medio que funciona localmente para Bristol pero también tiene relevancia nacional y transnacional. Distribuyen 30 mil copias en Bristol, pero la organización trabaja en una base de membresía, donde las personas pagan y tienen voz y voto en la decisión de las líneas editorialesy dela tiendaen general. Durante dos años, la membresía del Cable ha sido de 2 mil personas, cada una donando un promedio de 2,50 por mes, lo que ayuda a pagar el trabajo de los periodistas.

Otro ejemplo de este tipo moderno de producción de noticias es The Ferret, un buen periodismo de investigación en Escocia. Su sistema funciona de manera similar permitiendo a cualquiera suscribirse 
a una donación de un mes regular y ser parte de las reuniones y otras veces si se necesita tomaruna decisión. Por lo tanto, ambos puntos de venta complementan sus principales ingresos a través de membresías y eventos con el objetivo de ser autosuficientes solo con donaciones. El Ferret no tiene publicidad en absoluto, mientras que el Cable tiene publicidad en su edición impresa no en línea. Cable también impuso restricciones sobre los tipos de publicidad que aceptan y publicidad que es elegida colectivamente por los miembros. Por lo tanto, ambos puntos de venta son una fortuna, nuevos modelos para sostener el periodismo de investigación y mantenerlo libre de la influencia de propietarios individuales, corporaciones y anunciantes. Todavía no son autosuficientes, pero la cantidad de propietarios crece y la situación mejora.

En este contexto, ¿por qué las personas le pagan a esos puntos de venta? Bueno, el contenido del cable es de libre acceso, y los Ferret operan artículos gratuitos al mes para los no suscriptores, necesitan otras razones para que las personas les den dinero. Por lo tanto, en parte se debe a que el miembro compra la idea de que un medio esté interesado en sus intereses. Pero, además, estos puntos de venta tienen otras estrategias efectivas para asegurar la membresía, pero principalmente porque su periodismo está teniendo un impacto positivo de estas comunidades locales en la forma en que esta industria ha existido durante algunos años.

Tom Sanderson desarrolló ejemplos del impacto que han tenido estas noticias locales. The Cable hizo un informe sobre las construcciones de las casas en Bristol. Existe una ley que establece que los desarrolladores deben poner precios asequibles en las casas para gente pobre, pero siempre hay algunos desarrolladores en contra y discuten que sus inversiones no son suficientes. En este ejemplo, Bristol puede hacer una investigación completa de cuánto dinero se invirtió, quién invirtió, etc. Dejando en claro que el Público de China estaba invirtiendo en esta casa y cómo era posible que se rompieran con ese tipo de inversores. El impacto real se produjo cuando el consejo de Bristol decidió siempre ofrecer a los desarrolladores un precio estándar asequible para estas casas de la comunidad, así como la transparencia en la industria de la casa.

El Ferrell, sin embargo, realizó una investigación sobre los grupos de extrema derecha en Escocia. A través de una filmación encubierta demostraron que este nuevo grupo en realidad estaba compuesto por miembros de una organización neonazi recientemente prohibida para continuar con la violencia política. El Bristol Cable también investigó las finanzas de la Universidad de Bristol, y demostraron que gran parte del dinero de esta universidad se utilizó para inyectar gasolina a empresas junto con otras industrias éticamente cuestionables. Entonces, ese es un buen ejemplo de información de interés público que protegió al público de ser engañado por la declaración de una organización.

Tom Sanderson dice que aquí hay una necesidad de ayudar a la creación de las noticias locales y había identificado dos problemas principales: el tiempo y dinero. El Centro de Investigación, como organización benéfica educativa, no puede ayudar directamente a reducir estos problemas, pero puede capacitar a esta gente sobre la investigación y cómo administrar sus recursos de manera más eficiente. Recibieron un fondo para financiar la capacitación en habilidades de investigación, alentar a las comunidades locales y enseñar otros cursos como investigación en línea, derecho de comunicación y otros. Esperan algún día comenzar una red de comunidades locales y medios de noticias para reemplazar la propiedad de las corporaciones o los anunciantes. 
Foro,

Participantes: Juan C. Calderón: Director de Plan V, revista digital; Tom Sanderson: Journalism R Moderador: Paul Mena Mena, periodista de El Universo.

\section{"Periodismo de investigación a toda costa"}

Paul Mena Mena: Hablaremos de investigación y periodismo, me gusta empezar con una pregunta, es común esta cita que el periodismo de investigación es la garantía de la existencia de una sociedad democrática, pero ¿por qué es así? ¿Podemos aterrizar esa cita en algo más concreto en tu experiencia? ¿Cómo la investigación del periodismo garantiza la democracia en una sociedad?

Mariana Neira: Por qué el periodismo de investigación garantiza la democracia, es la pregunta. Bueno, porque el periodismo de investigación tiene una función o una misión para estar siempre alerta de lo que hace el poder, sea el poder político, poder económico, militar o poder religioso. Es necesario buscar el desempeño de qué trabajo están haciendo estos poderes. Es importante que tengan transparencia a la hora de trabajar para que la sociedad se sienta segura y protegida por todos los gobiernos y organizaciones. Básicamente lo que hace es mirar cómo se gestionan los recursos de la sociedad. Recursos que provienen de impuestos o recursos naturales. Entonces, esa función de vigilancia es lo que creó esta cita de que el periodismo de investigación es la garantía de la democracia.

Paul Mena Mena: Juan Carlos, sus investigaciones han sido reconocidas en Ecuador, especialmente El Gran Hermano. ¿Puede decirnos, por favor, si usted es una garantía de democracia en nuestro país?

Juan Carlos Calderón: De hecho, creo que el periodismo de investigación, es un método que puede defender el derecho a estar informado. La única razón, porque el trabajo periodístico es defender el derecho del público a ser informado de lo que los gobiernos, poderes, la sociedad están haciendo. Y ese derecho permite fortalecer la democracia. No es una garantía de democracia, o si no

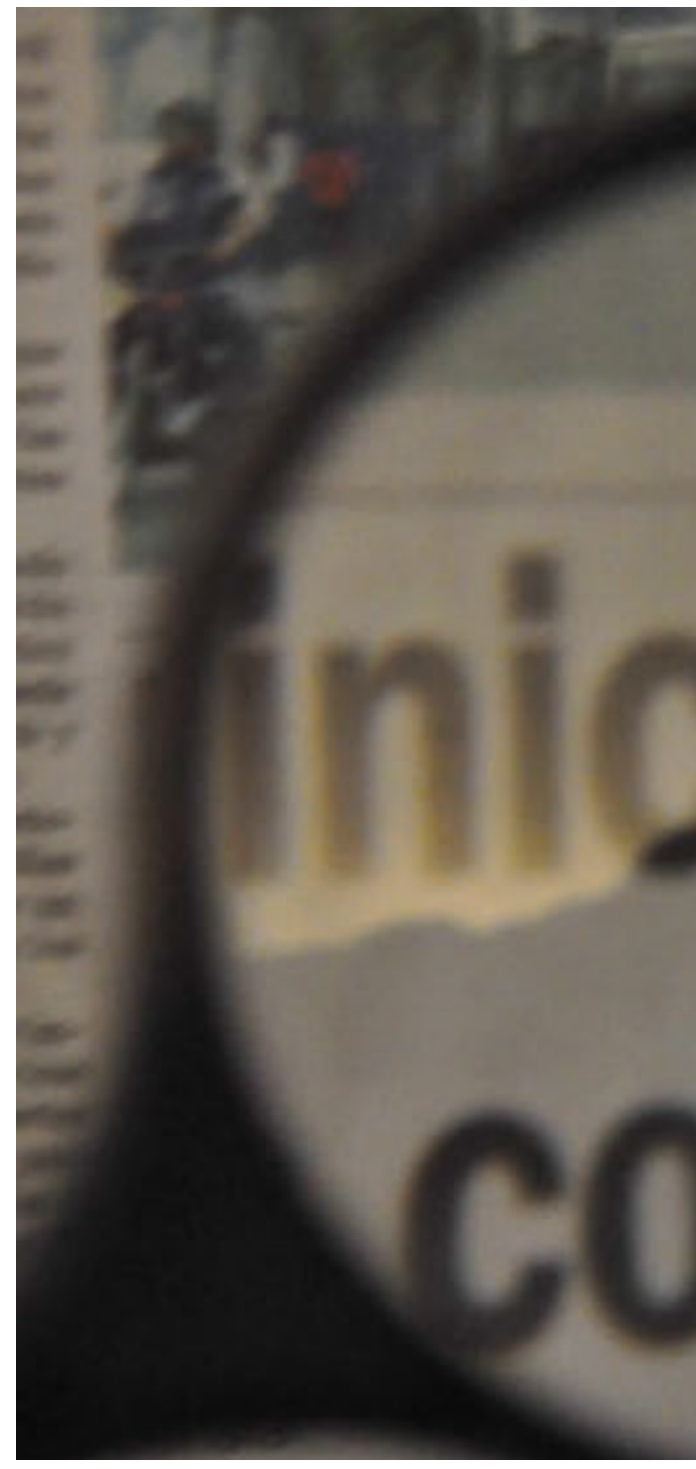


esearch Center; Mariana Neira: Presidente de Fundamedios y editora de la revista Vistazo.

Volver al índice - English Version. 
seríamos militares, pero es la información relevante la que permite eso. Ahora, las investigaciones realizadas por muchos periodistas y hablando de esta investigación El Gran Hermano que las negociaciones de los contratos vinculados al hermano del presidente generan un gran impacto y sin grandes complicaciones. Creo que esos fueron uno de los artículos, que se han hecho en el periodismo nacional en este país, que permitieron al público saber lo que otros intentaban ocultar. Porque el periodismo descubre lo que se esconde. $Y$ en este caso, el periodismo de investigación dejó saber algo que otros estaban ocultando y que era importante.

Paul Mena Mena: Tom, en tu presentación hablaste sobre lo que es necesario hacer para una investigación. Dijiste que necesitabas tiempo, recursos $y$, sobre todo, independencia. Ahora hay una crisis económica mundial que afectó a los medios. Los recursos económicos no son los mismos que 10 años antes en el personal editorial. ¿Cómo ves el escenario? ¿Puede esa falta de recursos afectar el periodismo de investigación?

Tom Sanderson: Estaba hablando de esto, sobre la falta de recursos como un problema importante para financiar el periodismo de investigación. Me refiero a como lo dicho, sólo hablaron en mi presentación, estas habilidades son cada vez más baratas y su publicación es cada vez más barata lo que realmente no va a ser una solución para cualquiera de nosotros. El periodismo de investigación siempre requiere de tiempo y dinero. Porque obviamente todos nosotros tenemos que pagar cuentas y vivir. Uno de los problemas que creo que está en nuestra sociedad, es que estamos acostumbrados a poder acceder a las cosas de forma gratuita, ya que la información y la comunicación a menudo están disponibles para nosotros. Pero entonces, ¿por qué la comunicación o la información como Google, Facebooku otros proveedores de correo no es gratuita? Se debe a que usted no es realmente un cliente en una relación, usted es el producto. Esto es el modelo de negocio de empresas como Facebook o Google, dónde están sus datos como un producto, no un servicio. $\mathrm{Y}$ el periodismo no funciona así y siempre vamos a necesitar dinero para hacer un buen periodismo de investigación y eso no es un argumento. La investigación en el periodismo es algo que nos debemos valorar y pagar por ello. Ese es un argumento que debería hacerse con más frecuencia y más fuerte.

Paul Mena Mena: Mariana, el ambiente del periodismo ha cambiado. Ahora está colaborando en el periodismo de investigación, ¿cuáles ventajas ves en estas nuevas plataformas contra el periodismo tradicional? ¿Ves una oportunidad allí? ¿Qué piensas?

Mariana Neira: Bueno, en realidad, vengo de los medios tradicionales en empresas que ya están organizadas y tienen todos los recursos para movilizaciones, logística y para mantener un grupo de investigación dentro de los medios, porque ustedes saben que los medios tienen que cumplir funciones y solo hay unos pocos que están completamente dedicados a la investigación. Más bien, desde la eliminación de la revista Vanguardia, no hay medios tradicionales dedicados exclusivamente a la investigación. Entonces, de esa mercancía que va a los medios digitales donde veo que el problema esla financiación. Debo aplaudirla creatividad que tienen para subsistir en la búsqueda de fuentes que los respalden en esta misión de trabajar exclusivamente para la investigación periodística.

Creo que hay públicos diferentes, todavía tenemos ese público objetivo que tiene una preferencia por los medios tradicionales, y esa es otra batalla entre los medios digitales y tradicionales porque lasúltimas estadísticas que tuve, y debe haber aumentado, es lo que, por ejemplo, Internet en Ecuador dio cobertura al $30 \%$ de la población. Es un dato 
que tuve en 2010 y puede estar desactualizado. De todos modos, digamos que el porcentaje ha aumentado al 40 o al $50 \%$, tenemos una gran cantidad de personas que todavía no están incorporadas a los medios digitales. Por otra parte, se ha convertido en una brecha generacional. Los medios tradicionales son seguidos por solo una generación de personas y los digitales están con las generaciones más jóvenes. Pero esos factores son los que algún día van a encontrar la forma de financiar ambos lados, los medios tradicionales y los digitales.

Paul Mena Mena: Carlos, Mariana decía que la creatividad es muy necesaria para conseguir financiación y mantener viva una revista dedicada a la investigación periodística. Ciertamente, la realización del periodismo de investigación no es barata y fácil. Soy un testigo de trabajar en un medio de comunicación tradicional y ver el esfuerzo que el propietario haga es para mantener el grupo de investigación. Hace algunos años, el grupo era un poco más grande, ahora ha sido absorbido por la cobertura diaria. Entonces, podemos ver el esfuerzo por mantener eso. ¿Qué es la creatividad? ¿Cómo en el Plan $V$ se mantien en el trabajo de calidad que tiene?

Juan Carlos Calderón: Yo trabajé con Mariana en Vistazo. Luego, trabajé en el grupo de investigación de Diario Hoy, donde nos fundamos Blanco y Negro, una columna de investigación que duró 20 años. Después de eso, en Diario Expreso que tenía un grupo de investigación donde trabajé durante 10 años. Y finalmente, la revista Vanguardia que cerró en junio de 2013. Entonces, como pueden ver, he trabajado en medios tradicionales, como dijo Mariana, en medios organizados que tenían su propia estructura de comercio y administración. Yluego, debido a la crisis y la situación, nos dejaron en la calle. Vanguardia se cerró y 13 personas se quedaron sin un trabajo, un fotógrafo, un diseñador y el personal de redacción. Entonces, ¿con qué íbamos a vivir? Porque eso es lo único que sabemos hacer. ¿Y cómo vamos a continuar para hacer nuestro trabajo con calidad mientras hacemos periodismo de investigación? Y así, contamos con el apoyo de organizaciones como Fundamedios y otras que siempre apoyaron a Vanguardia y dijeron, ' no podemos permitir que el periodismo de investigación guarde silencio'. Y esa fue una situación muy compleja para Ecuador y el periodismo.

En ese momento, la Ley de Comunicación fue aprobada, y Vanguardia cerró. Por lo tanto, hubo un poco de capital que permitió instalar en el Edificio de la Unión Nacional de Periodistas, una pequeña oficina con dos Macs para el diseño y el trabajo. Y que cambió totalmente la perspectiva de ser un editor, un entrevistador o un reportero de los medios de comunicación a ser un buscador de inversión sin ninguna experiencia. Imaginen que, casi tendré 35 años como periodista y 30 de esos años tuve una nómina salarial, preocupada por luchar contra el departamento comercial. Ahora, yo tenía que aprender la forma de crear este proyecto, la forma de mantener el trabajo y saber venderlo a nivel nacional e internacional. Y esa es la forma en que hemos estado trabajando. En ese momento, teníamos 13 personas y ahora somos cuatro. Las personas han dejado de ir, pero siempre seguimos trabajando. Hubo un momento en que era el único que seguía en el proyecto, pero al día siguiente seguí trabajando porque no sabía qué hacer.

Un año después de comenzar el Plan V continuamos, de una manera $u$ otra la diversificación de la búsqueda de fuentes y poner en marcha proyectos con organizaciones internacionales que nos ayudan a seguir con fondos o con la búsqueda de apoyo en la venta de membresías a personas que apoyan el plan V. Tuvimos que reinventar y crear una empresa que nos pueda ayudar a distribuiry vender el proyecto. Una empresa que no tenía nada que ver con nosotros, conmigo, porque el gobierno se encargó de hacerme ver como una persona tóxica, ya que estaba estigmatizado lo que 
hizo mucho más complicado para mí que la gente me apoye en este proyecto sin miedo. Hemos encontrado recursos que nos permiten cubrir ciertas necesidades. Por ejemplo, pagar la oficina, Internet, la movilización, los salarios, las colaboraciones.

El problema con Ecuador es que no hay experiencia en pagar por recibir información de calidad. El punto principal, creo, es que la publicidad pagó la factura y en el momento en que se digitaliza, en este tipo de proyectos, especialmente para la prensa gráfica, hay que buscar a alguien para pagar la factura y en este caso, debería ser el público, la gente, los lectores. Una vez tuvimos una conversación con un corresponsal en Holanda, que nos enseñó cómo funcionan y estamos tratando de aplicarlo, pero uno de nuestros principales objetivos era crear una estructura comercial porque ninguno de nosotros sabe cómo hacerlo, hemos aprendido a vender, a hacer proyectos, pero no hemos aprendido a gestionarlo y todavía nos queda camino por recorrer.

Paul Mena Mena: Entendemos que hoy en día hay una relación directa entre civiles y organizaciones de investigacióny periodistas. Yahemoshablado sobre cómo la investigación periodística es fundamental para la democracia, pero a la vez el trabajo con las organizaciones civiles es fundamental para el desarrollo de la investigación en el periodismo. Se puede decir Tom, desde tu experiencia ¿cómo se hace esa relación entre el periodista, las sociedades civiles y organizaciones?

Tom Sanderson: Puede funcionar muy bien. Algunos ejemplos son organizaciones de la sociedad civil que tienen varias prácticas periodísticas y habilidades para tratar importantes historias de interés público. Sin embargo, hay más preguntas sobre la objetividad de lo que necesita una buena investigación periodística. Hay casos donde las ONGs han hecho trabajo de investigación y no lo han publicado debido a que su función no es periodística, sino publican lo que encaja con la campaña. Sin embargo, para mí significa que no están haciendo investigación periodística, están simplemente haciendo campaña. Todos los periodistas deben tener objetividad, sin importar las ciertas perspectivas que provienen de las ideas fundamentales que dan forma a nuestras investigaciones y nuestras conclusiones. El punto de una buena investigación es que el periodista debe tener objetividad.

Paul Mena Mena: Tom nos hizo considerar la estrecha relación entre las fuentes, en el Periodismo de investigación cuando se enfrentan a grandes potencias, porque ese es el trabajo de la investigación periodística, dar a luz a algo que alguien poderoso quiere ocultar. Sin duda, los periodistas tienen que trabajar bajo mucha presión de personas en el poder sea político o económico. A partir de tu experiencia, Mariana, ¿cómo enfrentarnos para mantener independencia y objetividad?

Mariana Neira: En la realidad, es un tema complicado. Tengo experiencia en los medios que he trabajado. En Vistazo presentamos una queja por compras de tanques de guerra. Antes de su publicación, un militar lo leyó. Después de leer el artículo hablaron con el gerente de la compañía para ejercer presión sobre ellos para no publicar la nota. Al final, no renunciamos a la presión y publicamos el artículo. Sin embargo, he notado que no todos los medios pueden manejareso, porque tienen una debilidad económica que los hace renunciar a las presiones, especialmente los pequeños medios, y ese es el desafío más grande para las personas que se han involucrado en la creación de medios de comunicación sean tradicional o digitales.

Paul Mena Mena: La independencia y credibilidad son la mayor herencia que tenemos como periodistas. Juan Carlos, tomando ventaja de estar frente a un público joven, que son estudiantes de periodismo, a veces tenemos en cuenta que una investigación periodística es una especie de 
detective que está empujando a sí mismo en las vidas privadas, algo que no es muy real. De todos modos, hay cierta ética en el periodismo de investigación que fácilmente marca esos límites. Puedes decirnos algunos de esos límites éticos dentro de una investigación periodística para entender la diferencia entre la vida privada de las personas y un trabajo periodístico.

Juan Carlos Calderón: Tiene que ver con el interés público. Todo lo que tiene que ver con el interés público es tema de investigación periodística y los límites tienen que ver con buenas prácticas éticas. Sin ética, el periodismo no es posible. Cualquier trabajo no es posible sin ética. $Y$ las buenas prácticas periodísticas de investigación y periodismo en general deben cumplir dos objetivos específicos. Evitar que la información sea manipulada y no contestar a los intereses de la organizaciones. Debido a que todos los grupos de interés, ya sea el gobierno, las fuerzas armadas, las personas religiosas o cualquier otro grupo, siempre intentan poner la información bajo sus propios servicios, por encima del interés común. En el mundo de la redacción, siempre encontrarás eso. Y el trabajo de un periodista es precisamente prevenir que esto ocurra. No es fácil, pero solo pienso eso desde mi experiencia.

Todos nosotros hemos tenido experienciacon la censura o personas que quieren forzarte a que te censuren. En Diario Expreso, yo tenía una bomba en mi mano porque descubrí que la base militar de Manta se había convertido en un puerto de los Estados Unidos con la excusa de la lucha contra los carteles de droga. Además, tuve acceso al informe, la prueba, incluso los testimonios y me dijeron que no podían publicar debido a que obtendría varios problemas con Estados Unidos. $Y$ molesté a todo el mundo por tres meses hasta que me dijeron: "vamos a publicar". Así es como se hace. Ahora, ¿por qué publicamos eso? Porque fue un buen trabajo, porque nuestro trabajo es publicar. Ante cualquier circunstancia nuestra obligación como periodistas es publicar. La diferencia es que podemos hacer que un periodista trabaje usando técnicas sociológicas o etnográficas, pero al final del día nuestro trabajo es publicar eso. Si no es así no funciona para nada.

Ahora, lo siento porno responder a la pregunta directamente, sino en el sentido de cómo difieren entre lo privado y lo público lo sabrán una vez que comience a trabajar en el periodismo. De hecho, lo público es lo que a todo el mundo interesa, y si una autoridad tiene un amante no importa, pero sí que el amante está siendo financiado con nuestros recursos, entonces es importante.

Paul Mena Mena: Hagamos una cita, Tom dio una definición sobre lo que es público en su conferencia; él dijo que todo lo que es de interés público es lo que se refiere a los actos de corrupción que afectan a la sociedad en general 0 pueden afectar la salud 0 el bienestar de la sociedad. Entonces, en ese contexto sí se puede revelar un correo electrónico que contemple el interés común, ya que la ética del periodista dice que se puede publicar, pero si ese correo no tiene ese tipo de información, entonces eso es privado y la ética del periodismo dice que tiene que ser considerado como tal. Tom, la figura periodista se cambió en el sentido de que antes de que pudiéramos encontrar estos valientes periodistas que podrían hacer algunas grandes revelaciones, pero ahora esta cifra se ha perdido y en cambio se ha dado relevancia a la figura de una colaboración periodística. Hemos sido testigos de los Panama Papers y Paradise Papers realizados por ACIG ¿Cuáles son las ventajas de trabajar en colaboración?

Tom Sanderson: Primero, debo dejar en claro que mi organización es la $\mathrm{CI}$ no es $\mathrm{ACIG}$, así que no he trabajado personalmente con los Panama Papers. Pero creo en los beneficios yes muy cierto esta tendencia de colaboración entre periodistas. El periodismo y la industria han sido vistos como un trabajo individual, 


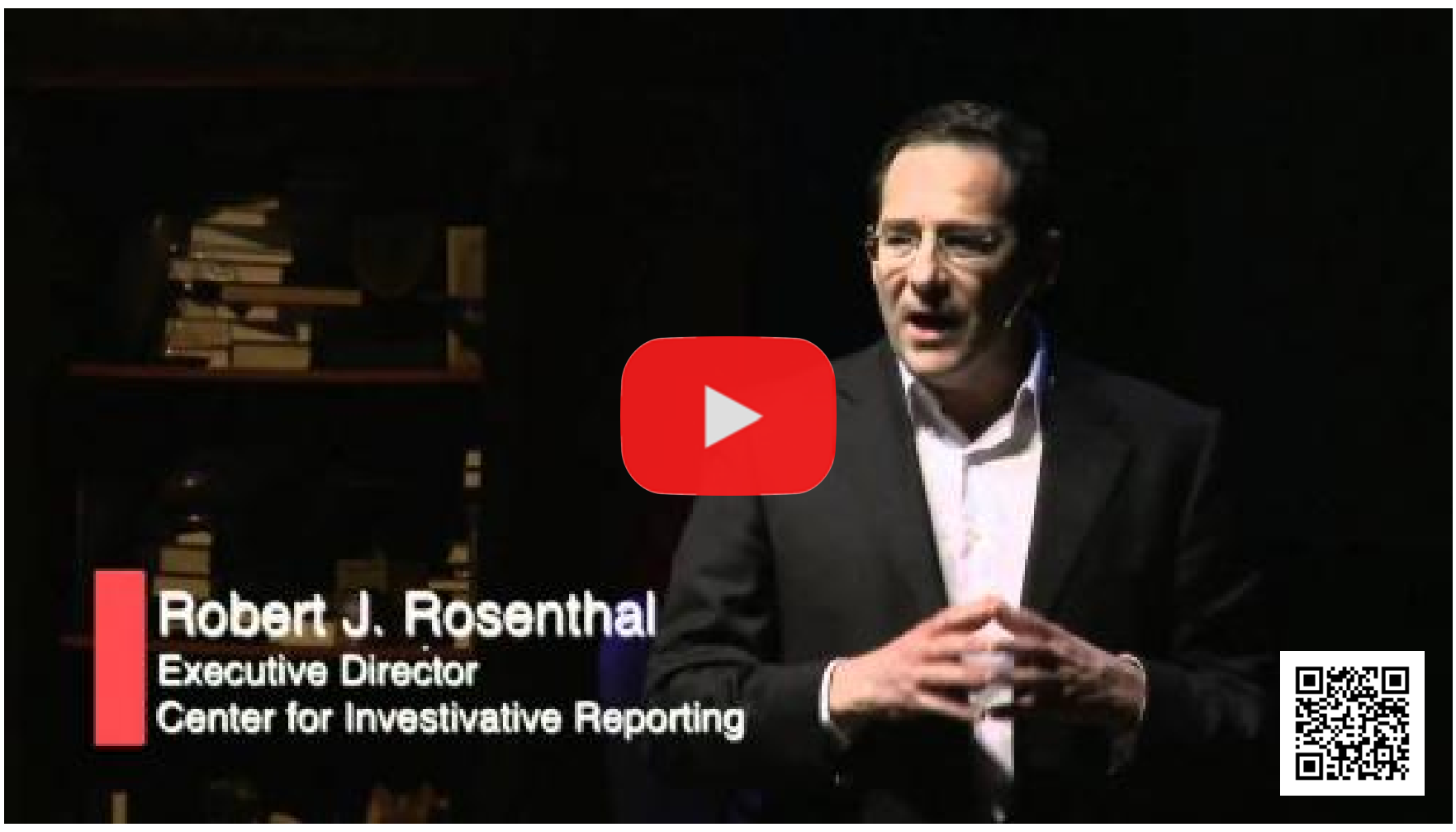

para mantener el resultado de su trabajo para uno mismo. Pero hemos visto en los últimos tres o cuatro años un verdadero movimiento hacia la colaboración entre periodistas sea nacional o internacionalmente. $\mathrm{El} \mathrm{Cl}$ es el ejemplo prominente de eso o, el EIC o, Investigar Europa, que deciden publicar grandes historias de este contexto nacional diferente con un diferente idioma, pero con relevancia internacional. Entonces, hay muchos beneficios en estos nuevos tipos de formas de trabajar. Primero, porque qué se puede hacer una historia que puede estar sucediendo igual en otros contextos. En segundo lugar, los recursos pueden ser compartidos. En tercer lugar, y posiblemente la más importante, se comienza a construir la confianza entre el periodista. Se inicia la construcción de conexiones y comienza a compartir la experiencia y habilidades, que no habría sido compartida de otro modo, lo que permite que la información se transmita

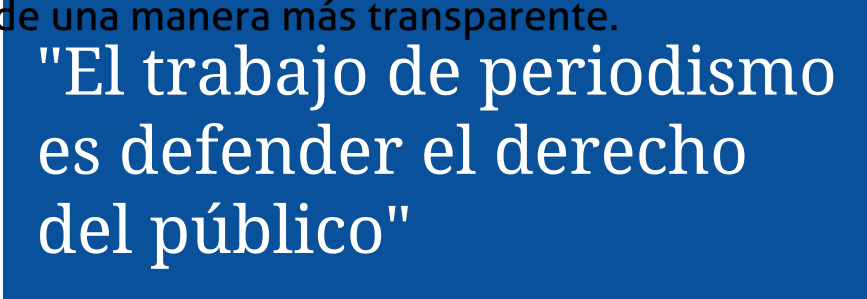

Sé que el ACIG tuvo al menos dos reuniones, la mayor parte de su trabajo se realizó a través de la comunicación a larga distancia y de reuniones cara a cara, para generar confianza, pero también para compartir experiencias y encontrar ángulos que podrían ser útiles para los contextos de otra persona, pero que no serían certeramente útiles para el periodista sobre cómo los encontró.

Por lo tanto, fuera de la colaboración no puede haber historias, para ejemplo los papeles Panama Papers se habrían perdido porque el periodista que los encontró podría haber pensado que no era lo suficientemente 
En cambio, con estas colaboraciones se pudo pasar directamente a alguien más a quien le pueda interesar y sobretodo interesar a sus lectores. Obtenemos más de la recuperación del trabajo de investigación y las filtraciones que la producción de este tipo de historias.

Paul Mena Mena: Mariana nos contaste tu experiencia personal con el gobierno, con el cierre de Vanguardia y esta idea que ha ido creciendo de la imposibilidad de hacer periodismo de investigación en nuestro país. Ahora el contexto de la política ha cambiado. Estamos con una nueva administración, pero ¿cómo se ve este nuevo entorno? ¿Cuál es tu pensamiento al respecto?

Mariana Neira: Ha cambiado porque no hay necesidad de investigar. Creo que hay más adrenalina en circunstancias difíciles. Quiero decir, el periodismo de investigación tiene que hacer cosas imposibles en gobiernos autoritarios para encontrar la información. $Y$ eso es lo que vivimos en la última década, cuando a pesar de la ley y la transparencia informativa, se nos negaba información importante. Entonces, hubo un desafío para el periodista en encontrar otras formas de buscar la información. Hubo muchos obstáculos que tuvimos que sobrepasar y esa es la diferencia, en trabajar en ese tipo de gobiernos. Ahora, en gobiernos más democráticos, hay más instalaciones para hacer trabajos de investigación, digamos que sí. Más aún, nunca tenemos que renunciar a nuestro objetivo básico que es estar atentos al Estado, sobre cómo están administrando nuestros recursos, el grado de transparencia o el grado de corrupción en sus actos.

Paul Mena Mena: Juan Carlos, Plan V creó el Museo de Corrupción, que ha sido muy bien acogido por el público. $Y$ ahora también ha comenzado una oratoria de laboratorio de innovación y se puede ver que hay un excelente trabajo de base de datos. ¿Cómo ves la herramienta del periodismo de datos para comenzar temas de investigación? ¿Cómo se está trabajando con esto y cuáles son las consecuencias de esta aplicación actualmente?

Juan Carlos Calderón: Creo que el periodismo ha trabajado siempre con datos. Lo importante es que esos datos sean reales. Ahora, creo que el periodismo de investigación en nuestro caso ha dado un salto al diseño digital o las nuevas narrativas digitales. En general, lo que solíamos hacer y continuamos haciéndolo, en algunos casos, es escribir mucho, mucho texto con recursos adicionales como multimedia como imágenes y sonido, infografías y eso es pensar en digital y no en narrativas digitales.

El Museo de la Corrupción nació después de que el ex presidente dijo que iba a dejar un museo de regalos, y de hecho lo hizo, entonces dijimos, "¿por qué no hacemos un museo de los casos de corrupción publicados en la prensa? ", y había tanta información de casos de corrupción que quedaron en el olvido que nos preguntamos cómo trabajar con esta cantidad de información y en lugar de poner 60 grandes historias en un libro, decidimos hacerlo amigable para el público y fácil para buscar la información. Por lo tanto, hicimos el museo donde la persona que está buscando puede encontrar todo tipo de información en los casos de corrupción y si están interesados en algún caso en específico pueden seguir investigando en el museo por más información. Entonces, esto se generó pensando digitalmente en un diseño digital. Aprendimos a cómo diseñar la in formación que teníamos y cómo aplicarlo a nuevas narrativas.

Tuvimos otra experiencia en las últimas elecciones. Teníamos que informar las elecciones, así que, como siempre, se iba a hacer una crónica y seguir al candidato y su grupo de campaña. Podríamos tener la misma crónica de hace 20 años y solo cambiar los nombres. Entonces, tendemos a repetir, ahora la pregunta era "¿cómo informar las elecciones pensando digitalmente, con narrativas digitales, con diseños digitales u otras alternativas?". 
Nos inventamos una urna virtual para que nuestro público, que no sabía mucho de los candidatos o de sus propuestas conozca al candidato. Además, los jóvenes no tenían ningún candidato que representar a sus intereses. Entonces, lo que hicimos fue reunir a un grupo de jóvenes con una ONG llamada Ciudadanía y Desarrollo e hicimos grupos focales y de ellos surgieron muchas preguntas para los candidatos. Diez preguntas y todas estas preguntas fueron para todos los candidatos. Y luego construimos una base de datos con estas respuestas e inventamos un algoritmo con el fin de combinar estas respuestas y que el elector participe en línea. El público también respondió las mismas preguntas que respondieron los candidatos. Ellos respondieron las mismas preguntas de sí o no. Por ejemplo, "¿estás de acuerdo con el aborto? " Sí o no. Diez preguntas contestadas por los candidatos y también contestadas por el público para que pudieran ver quién dio las mismas respuestas. Entonces, de esta manera, el público podría ver las coincidencias con su candidato o qué candidato coincide con su respuesta. Hubo preguntas complejas. "¿Estás de acuerdo con el matrimonio igualitario? "Sí o no. Y el público jugó y votó digitalmente.

La gente comenzó a jugar y vimos $150 \mathrm{mil}$ visitas en una semana. Además, el presidente actual, Lenin Moreno, fue el único que tardó un tiempo en responder las preguntas. Luego, cuando vio que teníamos tantas visitas, llamó y preguntó: "¿Por qué no está allí en este juego?" y comenzó a jugar también. Lo mismo hicimos para la segunda ronda con Lasso y Moreno. Por lo tanto, es todo acerca de la búsqueda de nuevas maneras de pensar la información digitalmente, tanto en periodismo de investigación y en una coyuntura de noticias, así como, de la misma manera como te imaginas nuevas formas para que el público participe. $Y$ esa es la gran ventaja de este digital mundo.

Paul Mena Mena: Tom, esta tendencia que está en el periodismo de datos, es difícil ponerlo en práctica en Ecuador en los medios tradicionales. La comprensión de que ahora Internet tiene millones de datos sueltos para contar una historia a la audiencia, se requiere un nivel de experiencia que el periodista no ha aprendido en sus universidades dado a la novedad del tema. Existe la idea de que un programador debe ser parte de la redacción, pero la idea no encaja bien en las redacciones tradicionales. $Y$ los periodistas han comenzado a aprender programación y es algo muy difícil. ¿Qué recomendarías para resolver esto? ¿Hay una gran oportunidad de periodismo de datos y cuál es la mejor manera de integrar esto en nuestra redacción?

Tom Sanderson: He tenido esta discusión con personas antes y es probablemente más fácil enseñar a un periodista a codificar que enseñar a un programador a hacer periodismo. Elhecho es que hay algunos elementos instintivos en la práctica del periodismo, que son difíciles de enseñar a alguien, sólo se puede aprender desde la práctica.

Mientras que la codificación una vez que tienes una conexión a tierra decente y la lógica de cómo funcionas, te puedes enseñar tú mismo fácilmente. Así, una de las formaciones más nuevas que se están ejecutando en $\mathrm{CI}$ ] es una introducción para la codificación para periodistas enseñado por una pareja. Uno es un codificador que trabaja para un cargo importante de Estadísticas Nacionales y uno que es un periodista de datos que trabajó siempre en el Times. La idea detrás de la formación del periodista consiste en explicar los beneficios que pueden obtener de la codificación, ya que es muy necesario; por lo menos en el Reino Unido, es importante para los editores introducir algunos conocimientos de codificación en el periodismo, ya que muchas veces se contrata uncodificador, pero no comprenden realmente si ellos deben tener un codificador o no y termina sentado en la esquina y eventualmente alguien le pedirá hacer infografía.

Una vez dicho esto, hay otros conceptos 
la necesidad de habilidades técnicas de computación. Muchas de las historias que se ve en medios tradicionales, provienen de datos. Todos están trabajando a partir de datos $y$, de hecho, algunas de las mejores historias de periodismo de datos no contienen ningún dato en absoluto. Entonces, regresaré a la analogía que usé temprano. El uso de Excel, por ejemplo, para trabajar con información, debería verse realmente como una entrevista, como cualquier otra que se realice a través de un idioma diferente. Por lo tanto, es lo mismo el aprendizaje del francés al entrevistar a un francés.

Público: Hemos hablado sobre el periodismo colaborativo y cómo los periodistas se pueden ayudar unos a otros ¿Cómo pueden los periodistas colaborar con otra área, no necesariamente entre colegas sino con personas de otras áreas que se formulan preguntas de un mismo tema? Yo estoy hablando de un verdadero multidisciplinario depende de otras experiencias y fuentes técnicas para comprender cosas que no conocemos. Lo que quiero decirle es que, sin fuentes relevantes y técnicas, no es posible hacer un buen periodismo.

Público: Como periodistas de investigación y trabajando en medios privados ¿Podemos decir que el medio es el mensaje?

Tom Sanderson: Sí, yo supongo que podemos llegar a esa conclusión. Pienso que debemos estar menos preocupados de no hacer el trabajo de los poderosos que desean evitar que los periodistas investiguen sus acciones. De hecho, significa que no necesitan hacer ese trabajo. Piense en ello como un problema mucho más pernicioso en la investigación del periodismo, la autocensura, las preguntas que no hacemos debido a los posibles riesgos.

Público: Estábamos hablando acerca de la presión que tiene el corresponsal haciendo

\section{Existe la idea de que un programador debe ser parte de la redacción, pero la idea no encaja bien todavía en las redacciones tradicionales}

grupo de redacción para trabajar en una investigación ¿Cómo se puede hacer esto y que beneficie al periodismo de investigación a largo plazo?

Juan Carlos Calderón: De hecho, todo el trabajo periodístico es siempre un acto de colaboración y cooperación flexible. De lo contrario, solo de periodista no existe. El periodismo es algo hecho con otros, para el periodismo de investigación este uno de los recursos fundamentales. Las fuentes técnicas te permiten conocer el tema. Uno tiene que ir a la búsqueda de una red de contactos y fuentes, con el fin de relacionar toda la información y obtener la información necesaria para probar su hipótesis. Ese es el trabajo que uno hace, pero sí, de hecho, uno investigación ¿Puede usted por favor decirnos su propia experiencia con la presión, mientras se hace una investigación y cuál es su reacción?

Juan Carlos Calderón: La mayor presión no fue cuando Rafael Correa nos pidió 10 millones de dólares de compensación por el Libro del Gran Hermano. La mayor presión fue cuando tuve que huir de Las FARC en la frontera, en la zona de Putumayo. Estábamos haciendo un reportaje en Vistazo. Un informe sobre cómo los grupos de las FARC estaban en la frontera cuidando los laboratorios de cocaína y las cosechas de coca. Hicimos un gran informe de ocho páginas y entrevistamos a los líderes guerrilleros de la zona, el comandante del frente 48 y luego publicamos el informe. 
Entonces, un amigo nos dijo que nos convertimos en un objetivo militar gracias a ese informe. Por tal motivo no volvimos a la zona. Un año más tarde volvimos para hacer un informe de una desaparición de un técnico en un negocio de la construcción. Tontamente volvimos a la zona de Las FARC sin ninguna seguridad o protección. Encontramos a las mismas personas que entrevistamos un año antes. La ventaja era que no nos reconocieron y uno de los partidarios que nos retuvo, nos dijo que iba a buscar a su comandante que era el comandante con el que hablamos un año antes y como él mismo dijo "estos reporteros de Vistazo publicaron una historia y ahora queremos matarlos". Entonces, con el fotógrafo encendimos nuestro cigarrillo, posiblemente el último que fumemos $y$ dijimos: " ¿qué podemos hacer?" $Y$ la respuesta fue "vamos a salir corriendo". Así, vimos un barco en el río y saltamos y comenzamos a nadar y fuimos capaces de llegar al barco y escapar. Fuimos perseguidos hasta Lago Agrio. Hasta ahora no he vuelto, no sé lo que podría haber pasado, pero creo que fue el momento más serio que he pasado. Ahora es bastante divertido.

Público:¿Qué herramientas usar para no hacer la investigación algo personal? El año pasado hablamos mucho sobre Rafael Correa y varios otros temas quedaron atrás por eso. ¿Cómo podemos saber cuáles son las herramientas para usar y hacer más investigaciones y no quedar atrapados en lo mismo todo el tiempo?

Mariana Neira: Siempre hablamos sobre dónde está el límite de la investigación y vuelvo para contarte lo que pasó con el fiscal esta semana. Me dijo "pero debes saber quién es el sospechoso de la desaparición de esta persona" y le dije "no estoy aquí como fiscal, estoy aquí como periodista". Nosotros, los periodistas hacemos una exposición de los datos, es la forma en la gente tiene sus propias conclusiones. No somos los jueces, así que ese es el límite de nuestro trabajo porque la confrontación es hecha por la autoridad. Hay una delgada línea entre el periodismo de investigación y la parte legal, fiscal y jueces. Al menos esa es la forma en que yo hago mis investigaciones.

Público: ¿Y cómo no hacer una investigación repetitiva? ¿Cómo no la convertimos en una investigación personal?

Mariana Neira: No creo que la investigación se haga con motivos personales, a menos que sea tendenciosa o manipulada políticamente. Te contaré otra anécdota.

Tuve un tipo que trabajó conmigo y yo estaba trabajando en un medio público al comienzo de este gobierno porque me presentaron la idea de los medios públicos. Leí y estudié qué significaba este concepto en Europa y me llamó la atención. Me dieron un grupo con un periodista cuando el camino de los medios públicos comenzó a ir de otra manera y dependía del gobierno. En ese momento, la gente comenzó a ponerse nerviosa. Le dije que teníamos que hacer esta investigación y me dijo "¿a favor de quién? ¿El gobierno o la compañía?" . Le dije " no", la investigación no se hizo para estar a favor de algo o alguien. La investigación es la confrontación de los hechos y evidencias en la forma en que se establece una conclusión se puede decir que una persona es efectivamente un traficante de drogas o no es, por ejemplo. Hay algunos casos en el periodismo donde la investigación se detiene porque si tuviéramos el caso de un caso de corrupción, pero vemos que eso no es cierto. Preferimos detener y eliminar ese informe e ir de otra manera, a otro tema.

La investigación depende de la planificación editorial, es por eso por lo que tenemos una. En grandes medios de comunicación, el personal se reúne todos los días y determina el tema para hablar y los pasos que deben realizarse. Pero dices, "¿por qué siempre vamos con el mismo tema?". Hay otros grupos que nos critican cuando hay continuidad a ciertas historias y cuando no hay continuidad a las historias no hay ninguna conclusión. Otro ejemplo de los derechos humanos es que si 
nosotros, en los años 80, no dábamos la continuidad que hicimos a esas investigaciones, no hubiéramos descubierto, o parcialmente descubierto, el caso de las hermanos Restrepo. Remontamos la historia, entrevistamos a la familia, el proceso legal, hasta que los jueces determinaron que era una desaparición forzada. Entonces ese es un objetivo que buscamos como investigadores y periodistas.

Eric Samson: Hablé con una estudiante que tenía dudas sobre la carrera y le conté una historia en la que pude hacer un cambio importante. Puede alguno explicar rápidamente una experiencia que ha cambiado algo o hizo lo correcto para que los estudiantes sepan que esta carrera no nos hará ricos, pero podemos cambiar cosas importantes en el mundo.

Mariana Neira: Una de mis satisfacciones fueron los logros que tuvimos en algunos casos de desapariciones en los años 80 .

Paul Mena Mena: Yo puedo hablar sobre las experiencias que tuvimos con los Panama Papers donde hemos hecho un gran informe sobre cómo una compañía china falsificaba algunas facturas e informes con el fin de evadir impuestos aquí en Ecuador. El resultado fue parcialmente optimista porque en un lado el SRI pudo cobrar 65 millones que evadió esta empresa, pero por otro lado se abrieron algunas investigaciones legales como falsificación de documentos y de una manera muy sospechosa un fiscal dijo que como los chinos ya han pagado los 65 millones de dólares, no hay crimen. Esa es una norma doble porque nos hemos dado cuenta de que en otros casos los fiscales han tenido otros juicios. No, todavía hay un delito en otros casos, así que debemos darle continuidad a ese tema.

Juan Carlos Calderón: Hice una investigación sobre una historia de una mujer que estaba en la cárcel por más de 12 años porque ella mató a su marido en defensa propia, porque él la quería matar. Ella era una víctima de violencia por más de 30 años y ella lo mató en una pelea y fue sentenciada a 12 años de prisión. Hice la investigación y probé cómo el asesinato realmente ocurrió y cómo los jueces no lo vieron. Después del informe un grupo de abogados tomaron el caso y ella obtuvo su libertad. Creo que uno hace periodismo para ayudar a la gente.

Tom Sanderson: Solo quisiera volver a mi ejemplo y mostrar que, aunque siempre hay personas que tratan de tomar los medios e influir en formas para los intereses específicos propios. Estas son también formas en que recuperamos nuestros medios como público y lo hacemos sobre todos nosotros. 


\section{Christoph Geiseler,}

Fundador y CEO de Seenfire Foundation (EE. UU.)

Volver al índice - English Version

\section{Conferencia magistral: "Producción de vídeo en microcuentos virales, una macro tendencia"}

Christoph proyectó el vídeo de un chico mexicano construyendo su propia empresa; el siguiente vídeo fue un informativo. Entre ambos, las similitudes fueron que tienen muchas imágenes y dura 60 segundos exactamente. Por lo tanto, puede ser algo que promueva un producto, algo más informativo, pero el tiempo es lo que tiene en común. Estos fueron hechos por dos estudiantes de Christoph, uno esta semana en Guayaquil y el otro el año pasado.

En 1997, Christoph recibió su primera cámara y 20 años después continúa haciendo el mismo trabajo, viajando y grabando. Algo sucedió entre esos 20 años. Al graduarse, su padre le preguntó: ¿qué es lo que quieres para estudiar? Él respondió fotografía y su padre dijo, imposible debes estudiar algo serio. Christoph dijo que una carrera de fotografía era seria y que ser artista era su sueño. Pero su padre dijo que debía ir por algo más serio donde se podía ganar dinero y ser respetable. Así que, él dijo: estudiaré política, para que su padre sea feliz, y así aprenderá algunas cosas. Él pensó, que cuatro años de política era demasiado, por lo que decidió que realmente quería ser un fotógrafo.

Irónicamente, ahora trabaja en 60 embajadas americanas donde aprendió a nunca decir nunca, ya que a veces su trabajo tiene algo político o cultural y que tiene para explicar de qué se trata al usar un video.

Hablando visualmente, ¿cómo podemos usar vídeos para comunicar lo que está sucediendo? Primero, ¿qué son los vídeos de un minuto? Son historias cortas construidas en una narrativa internacional e involucran a los televidentes en un ecosistema digital. Entonces, las dos palabras importantes aquí son: narrativa

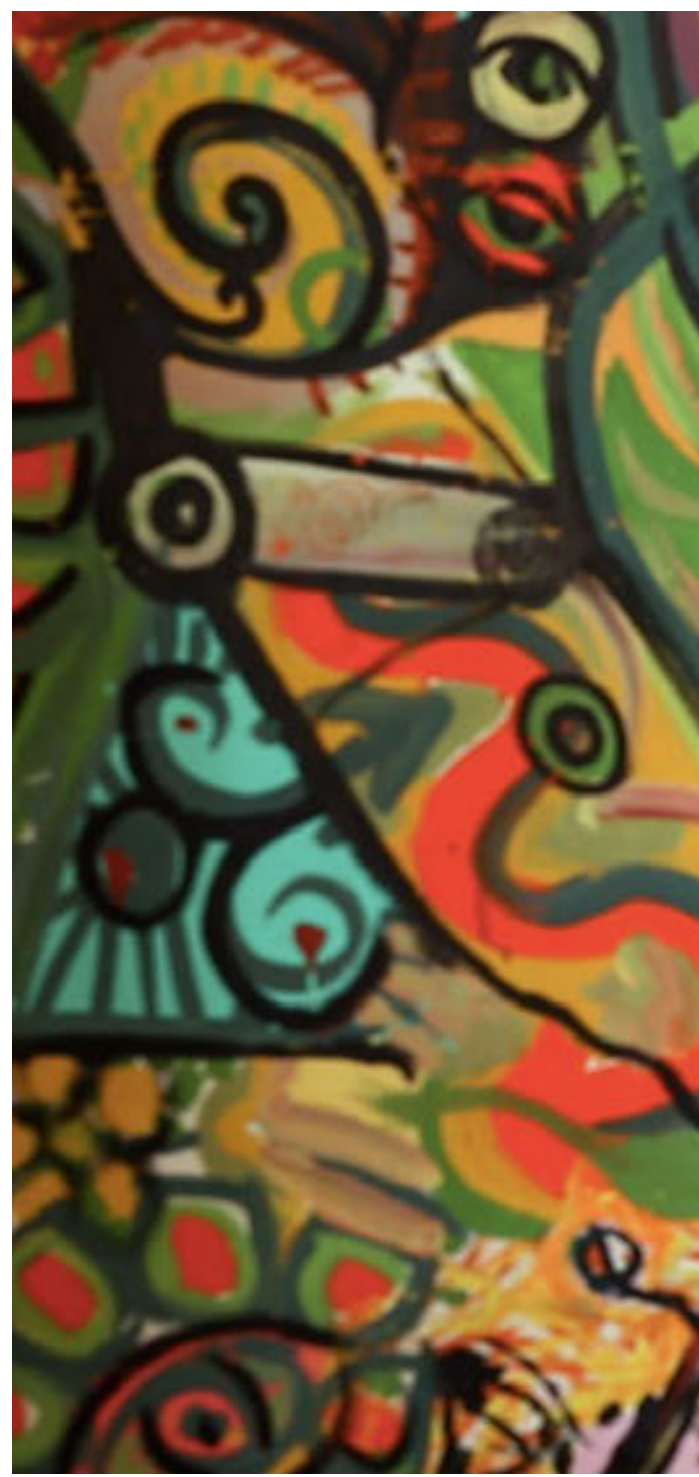
internacional y ecosistema digital. 


\section{Día 02}

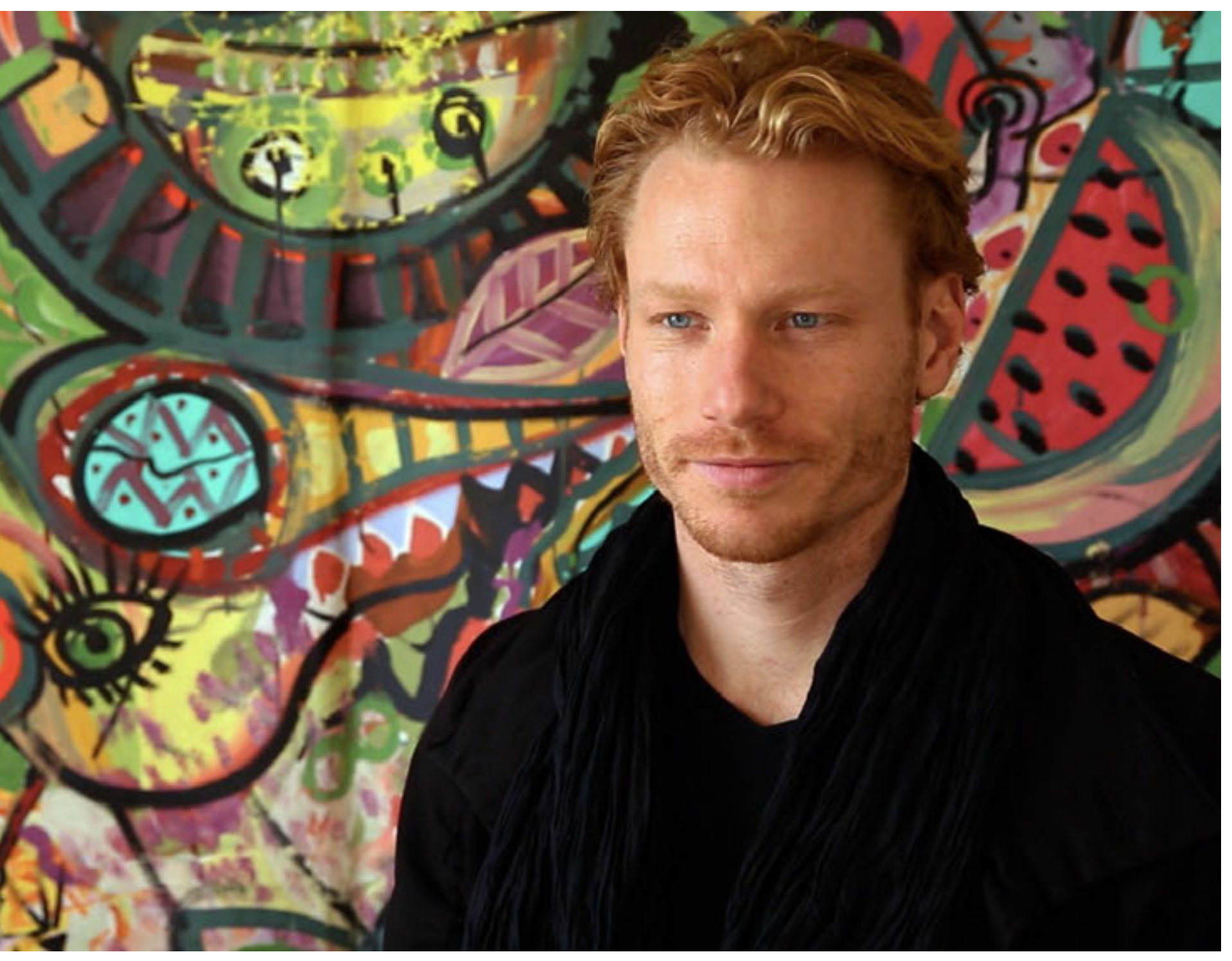


La narrativa internacional significa que, si ponemos un vídeo en Internet, una persona lo verá en Quito y otro en Australia, que es internacional. No necesitan 20 personas para mirar el vídeo y decir que esto es internacional y eso es importante, solo se necesita a dos personas para ver un vídeo y tener un impacto, y también significa que nunca sabemos quién va a ver el vídeo. Entonces, tenemos una gran responsabilidad al hacer vídeos. El ecosistema digital es pensar que este ecosistema es una jungla, por eso hacemos tweets, comentarios, blogs, fotos, música y vídeos, y cómo sabemos lo que las personas usan.

Hay mucha competencia, cada contenido luchando contra cada uno. Tenemos que saber qué contenido sería más probable que sea visto por una persona, y podría ser frustrante o aburrido, pero la lucha siempre está ahí. Por lo tanto, lo que quiere Christoph es mostrar el ecosistema de una forma más interactiva una cámara, pero hay un costo detrás de eso. La puesta en marcha. Cuando estamos haciendo un vídeo, tenemos que planearlo, lleva tiempo. Además, la seguridad, ya que el periodismo es una profesión arriesgada. Estas 6 palabras hacen una: estrés.

Hacer vídeos es algo estresante. En cualquier momento, que se intente hacer un vídeo, se sentirá estresado y confundido sobre cómo hacerlo. Lo recomendable es que, si se inicia la edición de los vídeos, y comienza a convertirse en algo estresante, tienes que parar, ir a tomar una cerveza, llamar a un miembro de la familia, ver una película y volver a editar cuando te sientas mejor. Porque hacer vídeos debe ser divertido, y en el momento en que se vuelve estresante, no vale la pena. Entonces, esa es la filosofía que debes tener.

Cuando pensamos en hacer vídeos, hay tres fases. Primero, pre producción. Es todo el

\section{Todo el mundo está pensando "o tenemos el video para mañana o Snapchat para hoy", pero tal vez eso sea lo que verán nuestros nietos dentro de cien años.}

donde todo está conectado. Significa que, si ponemos un vídeo, alguien podría tomar la música, alguien la foto, otra la idea. La idea es compartirlo, y eso sucederá con nuestro vídeo, pero al mismo tiempo podemos hacer lo mismo con el vídeo de otra persona. Esa es la idea de impulsar y recuperar vídeos. $\mathrm{El}$ contenido siempre se está moviendo en este ecosistema digital. Entonces, puedes verlo como un ecosistema competitivo o algo más sincronizado.

Ahora, hay un costo al hacer vídeos. Primero, el personal. Alguien tiene que hacer el vídeo, alguien tiene que grabar. Entrenamiento, alguien tiene que estar en constante aprendizaje, como nosotros en este momento. Necesitamos recursos, ¿quién paga el avión, los viajes, las baterías? El equipo también es necesario. 0 puedes comprar un teléfono o tiempo antes de hacer el vídeo. La logística, la recarga de las baterías, solicitar los permisos, comprar boletos, equipo de alquiler, todo lo que es pre producción. Debido a que el segundo empezamos a grabar hasta que termine de grabar, que se llama producción. De dónde provienen el sonido y las imágenes, las entrevistas y toda la grabación. Y, por último, tenemos la post producción. Eso es todo lo que sucede después de la grabación. Desde el programa que estamos usando para editar, en donde estamos manteniendo todo el contenido grabamos, cómo estamos compartiendo y qué suceden con estas historias en un centenar de años. Todo el mundo está pensando "o tenemos el vídeo para mañana o de Snapchat para hoy", pero quizás es lo que van a ver nuestros nietos en cien años. Entonces, tenemos que pensar en el presente, pero también tenemos que tener 
la visión en el futuro. Entonces, ¿cuál es nuestra estrategia para hacer vídeos?

Los vídeos de un minuto requieren disciplina. Es mínimo 1 minuto, máximo 1 minuto. Ese es el concepto más fácil e irónicamente, los estudiantes no pueden aceptar eso. Por lo tanto, los vídeos no son para nosotros, son para el público y tenemos que aceptar que no desean ver vídeos demasiado largos. Es entonces cuando tenemos que tener mucha disciplina para poder poner tanta información como podamos en un minuto. Otra cosa que es importante es poder filmar y editar en 24 horas. A veces las personas piensan que, si pueden hacer un vídeo de dos minutos en dos días, y así sucesivamente, vídeos de tres minutos en tres semanas. Esa es la idea, hacer un vídeo de un minuto en un día con el objetivo de reducir el tiempo y el costo de pre y post producción. No importa en qué país o en qué situación, si acude a su jefe y le dice que puede reducir los costos, se sentirán felices. Entonces, la idea también es tener una ventaja sobre los costos y el tiempo.

La estructura de un vídeo de un minuto es primero, música. La música atrae a la gente. Hay una diferencia entre el jazz o el rock and roll o ver un vídeo con música clásica o folklore. Cada tipo de música trae una emoción diferente. Entonces, tenemos una narrativa o entrevista. Si estamos haciendo un video de un minuto, el máximo de palabras es 150, porque después de ese número de palabras, tenemos que hablar muy rápido. El video también es importante.

Los videos y fotos refuerzan lo que estamos tratando de decir en la narración, cuando promocionamos un producto, cuando alguien está mirando el vídeo, están escuchando música y están recibiendo información y mirando imágenes. Hay tantas sensaciones activas. Pero los vídeos también tienen que tener un desafío, si estamos haciendo un vídeo sobre el reciclaje y las estrellas del vídeo dicen: "mi compañía es la mejor del mundo porque estamos reciclando". Eso es aburrido, porque es un manifiesto y no queremos eso, queremos autenticidad, pero si empezamos con un reto como: Yo vivo en Quito, y veo un montón de basura en la calle y es un problema, el público dirá, "si, eso es real, lo he visto". Entonces, luego se dirige a la solución.

Si el vídeo comienza con un desafío, el público quiere saber la solución, entonces les mostramos la solución, con imágenes y vídeos para llamar a la acción. Y con esa llamada, invitamos a las personas a visitar una página web, a llamar a un número y ser parte de ese movimiento. Los usuarios quieren tener esa vocación.

También puede escribir una nueva narrativa sobre un registro una y otra vez y usarlo en elvídeo para reforzar la información que desea que su público para escuchar. Entonces, la pregunta es, ¿cómo podemos usar vídeos de un minuto? Primero, para productos y publicidad. Para informes, los periodistas tienen que informar en el mismo día. Para obituarios, celebrar la vida de alguien. Para la recaudación de fondos, con el fin de invertir en un vídeo parallamar a las personas a invertir en el negocio, ideas, sueños, todo. Para ocio, eventos, conciertos, etc. Para una viñeta 0 vídeos instructivos, incluso para salir, porque algún día, Christoph piensa que, en lugar de una foto, en nuestras redes sociales usaremos vídeos para decirles a los extraños quién somos. Los vídeos de un minuto también son útiles en la solicitud de empleo, se pregunta si en Ecuador esta tendencia ha comenzado, pero seguro que cree que pronto comenzará. Podráshablar sobre la experiencia y ser capaz de mostrar cómo hablas, cómo te vistes. Finalmente, para dar tu opinión. Todos estos usos deletrean PROFILE VIDEO. Facebook tiene millones de usuarios y cuando nos lo dice, ahora puedes tener vídeos de perfil, todo el mundo lo hace. Qué imágenes vamos a usar, qué música es apropiada, por lo que, si no está sucediendo ya, lo hará. Cómo mi vídeo de perfil me ayudaría a interactuar, con otros a encontrar 


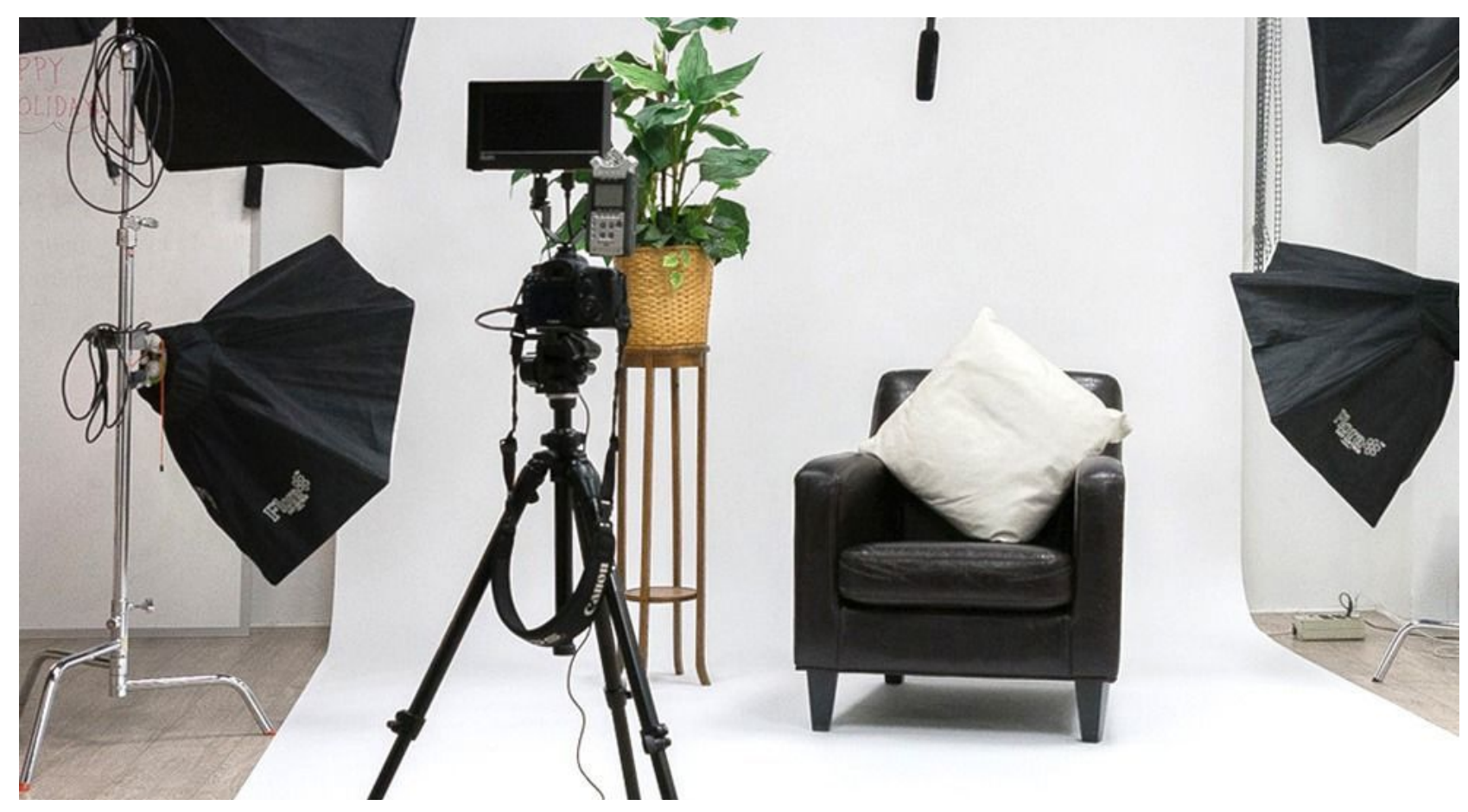

Una nueva manera de hacer periodismo

La tendencia de que la información sea cada vez más concisa está en auge. Es momento de comprender las nuevas necesidades de los públicos objetivos a los que nuestro medio esté dedicado y asi poder otorgar material de calidad enfocado a las nuevas necesidades tanto de los medios como de sus consumidores.

trabajo, a encontrar el amor, la amistad, cualquier cosa.

Entonces, ¿cuál es el impacto de la enseñanza de vídeos? Primero, vídeo alfabetización. Vamos a la escuela para aprender a escribir, tocar instrumentos musicales, estudiar cultura e historia. ¿Pero cuándo van a empezar a mostrarles a los niños cómo hacer vídeos? Seguramente, en el próximo año, los vídeos serían parte de la educación. Entonces, es importante comenzar y aprender eso ahora, dándonos ventaja. Entonces, las personas pueden tener más confianza creativa, para hacer algo más personal, más artístico o más inspirador. $\quad Y$ finalmente, el empoderamiento es cuando alguien, un barrio o pueblo aprenden a hacer algo nuevo. Es ahora una novedad el tener un impacto social.

¿Cuál es la lógica de los vídeos de un minuto? Establece expectativas porque a la gente le gustan los vídeos cortos. Reduce costos porque no queremos usar más dinero y más tiempo para hacer vídeos. Queremos reducir eso. También refuerza una marca que las personas en el vídeo pueden usar en las camisetas y en todo el vídeo. También se entretiene porque los vídeos no siempre tienen que ser serios, pueden ser divertidos.

El vídeo también le da autenticidad y la gente quiere ver algo real, algo auténtico. Es un archivo de medios, como ya dijo, lo que sucederá con nuestras historias cien años después. Si tenemos suerte, podríamos tener una foto de un abuelo en blanco y negro, así que imaginemos que nuestros nietos podrían tener vídeos de nosotros mismos. Imagine esa diferencia en esta experiencia intergeneracional, para preservar la cultura o la familia. También funcionar como una ubicación de logotipo, 
tener una foto de un abuelo en blanco y negro, así que imaginemos que nuestros nietos podrían tener vídeos de nosotros mismos. Imagine esa diferencia en esta experiencia intergeneracional, para preservar la cultura o la familia. También funcionar como una ubicación de logotipo, por lo que, en lugar de hacer un vídeo de 5 minutos, ¿por qué no hacemos 5 vídeos de 1 minuto donde puede ver más veces su logotipo, además de que puedo pedir más dinero? Entonces esa también es una forma de hacer negocios, las personas pagarán lo mismo por un vídeo de 5 minutos o uno de 1 minuto. Aumenta la transparencia. Si estamos compartiendo lo verdadero, los periodistas y las organizaciones quieren decir la verdad. $Y$ finalmente, vídeos narrativos que tienen una historia, una voz detrás del vídeo es fácil enseñarles a amigos o estudiantes o a un niño hacer un vídeo de un minuto de duración que de 35 minutos. Al usar todas esas palabras, podemos escribir STREAM LINE. Eso significa que trabaja inteligentemente. Si tenemos estrategias y métodos para hacer vídeos de un minuto, podemos usar menos tecnología y tener tiempo para otras cosas. Si aprendemos a usar la tecnología de manera inteligente, es posible que no tengamos que usarla.

En una conferencia, más interactiva, Christoph, explicó que, en primer lugar, cabe preguntarse si el vídeo es comercial o no. Al final del día, todo lo que estamos intentando es ganar algo de dinero. Por lo tanto, es importante determinar nuestro público objetivo y hay una gran diferencia entre hacer vídeos para niños o sobre niños. Por ejemplo, estamos haciendo un vídeo para hombres de 80 años que aman el póquer o un vídeo para niñas de diez años a quienes les gusta jugar con muñecas. Esos son dos públicos completamente diferentes. Para los hombres que juegan póker tal vez deseen escuchar la música clásica, pero sipones la música clásica las niñas, no van a funcionar.

Hay que utilizar lo que el público quiere escuchar. Después, ¿quién estáhablando? Por ejemplo, si estamos haciendo un vídeo sobre los derechos de las mujeres, tendríamos una mujer hablando o si nuestro público es los 80 años, los hombres, el mejor narrador es otro hombres de 80 años que hablan porque pueden identificarse. Esas son decisionespara quién es el mejor narrador para su público. Otra cosa es cuál camiseta va a vestir el narrador y hasta qué imágenes vamos a usar ¿Son fotos, vídeos e incluso qué filtro vamos a usar?

Christoph alienta a toda la audiencia a escribir un vídeo que harán. ¿Qué historia usarán? ¿A qué público, con qué música, narrador, vestuario e imágenes? Luego, hizo que todos lo compartieran con un amigo. Este proceso, como él dice, ayuda a las personas que trabajan con los colegios para contar lo que están planeando hacer, antes de mirar, la gente que ha escuchado le puede dar un consejo para hacerlo. En el peor de los casos, si lo muestras y hay personas a las que no le gusta, tenemos que comenzar todo de nuevo. Ese es el proceso.

Mostró cómo usar la cámara. Hizo que todos se pusieran de pie y dio consejos sobre cómo usar una cámara. Christoph, se puso de pie con los pies separados y los codos al lado del cuerpo. Los pulgares deben sujetar el teléfono desde la parte inferior del teléfono. También dijo que lo menos que podemos grabar es 10 segundos, por lo que puede ser editado.

El consejo final fue tomar todo el tiempo que necesite para hacer el vídeo perfecto. La estética es muy importante, seguir la regla de los tercios, usar la rutina y usar la mejor luz y audio para que tus fotos afecten tu video y su impacto. 
Toa Maldonado,

Cofundadora y vicepresidenta de APAK, productora de televisión kichwa Volver al índice - English Version

\section{Conferencia: "Producción intercultural de Otavalo"}

Toa es parte de la asociación de productores de kichwa, APAK, asociación conformada por personas kichwa Otavalo. En 2006, un grupo de cuatro jóvenes de Otavalo con una niña Puruhá comenzó un proyecto para lanzar una revista cultural televisada. Empezó porque desde hace muchos años las culturas kichwas vieron informes en revistas o documentales que hablaban de ellos, pero ninguno de ellos era real. La mayoría de las veces las culturas fueron exotizadas 0

folclóricas. En la experiencia de Toa, cuando tenía alrededor de 14 años, llegó una investigadora inglesa en la biblioteca de su madre en Otavalo. Comenzó a hablar con ella y se hizo amiga fácilmente. Dos años después, su madre recibió un libro de historias de mujeres indígenas en Ecuador. Su madre reviso y mostró a Toa lo que tiene dentro. Donde se encontraba la historia de su madre y fue un como leer una historia folclore, muy exotizada. Su madre es kichwa otavalo y su

\section{Cuando Toa comenzó a involucrarse con APAK, comprendí la necesidad de crear y promover un contenido objetivo de lo que representaban las culturas Kichwa.}

padre no, por lo que Toa siempre se ha reconocido como kichwa otavalo. En ese libro, se la interpretó como una hija bastarda de media sangre. Su madre consideró que ese libro era una broma para el recuerdo de todas las mujeres retratadas allí. El libro fue una tesis de doctorado de esta mujer inglesa y lo publicó en Ecuador. Su madre nunca la vio sacando una grabadora o tomando notas, por lo que parecía que toda la historia provenía de la mente de esta investigadora.

Esta historia fue una experiencia muy personal de Toa, pero ella siempre ha sentido que es el mejor ejemplo para entender cómo sus culturas han sido muy exotizadas en los medios. Eso es algo que no los representa. Más tarde, cuando Toa comenzó a involucrarse con APAK, entendió la necesidad de construir y promover un contenido objetivo de lo que las culturas kichwa representaban. 
En 2009, APAK está conformado legalmente con la necesidad de encontrar fondos del Estado $u$ otras organizaciones para poder trabajar. Durante años, APAK no recibió ningún tipo de dinero, sino que se autofinanciaba con cualquier vídeo audiovisual que se solicitara a los comerciantes locales. De esta manera, APAK comenzó a crecer. Uno de los primeros reportajes que hicieron fue "Mindala", que hablaba de los recuerdos orales de la gente de Otavalo como viajeros y comerciantes de todo el mundo. El proyecto fue muy interesante, tomó más de un año en su fabricación y un año en la edición y publicación.

Toa explicó lo interesante que fue la realización de este documental porque, donde quiera que vaya, siempre encuentra a una persona kichwa otavalo. Lo que hizo el documental fue tomar todas las historias orales de cuatro comunidades en Otavalo, hablaron sobre la importancia de estos flujos migratorios. Recordó que en 2005-2006, el presidente de la época dijo que los otavalo son los embajadores culturales de Ecuador, porque más que tomar el arte y la música, traen la cultura y las tradiciones a donde sea que vayan. Además, Otavalo se convirtió en el centro de turistas que querían ver esta cultura.

Mindala significaba una categoría que se visibilizó durante muchos años y logró que muchos otavalo se reconocieran a sí mismos como Mindalas, no solo eran viajeros o comerciantes, sino embajadores culturales. Este documentalfue premiado y presentaron los documentales en todas las comunidades investigadas para poder hacerlo. Y verse a sí mismos en el video o ver a alguien que ellos conocen era muy importante y escuchar sus comentarios fue lo que les permitió construir el documental paso a paso con las comunidades.

Así es como APAK comenzó a mejorar el conocimiento, el equipamiento y la calidad. Desde 2006, el documental 'Bajo Sol' se ha transmitido en la televisión lo cual es muy difícil porque la mayoría de los productores kichwas comienzan el camino, pero a medida que pasa el tiempo, dejan atrás los proyectos. Así que el trabajo de APAK ha sido continuo con sus limitaciones, pero ha sido un trabajo muy gratificante.

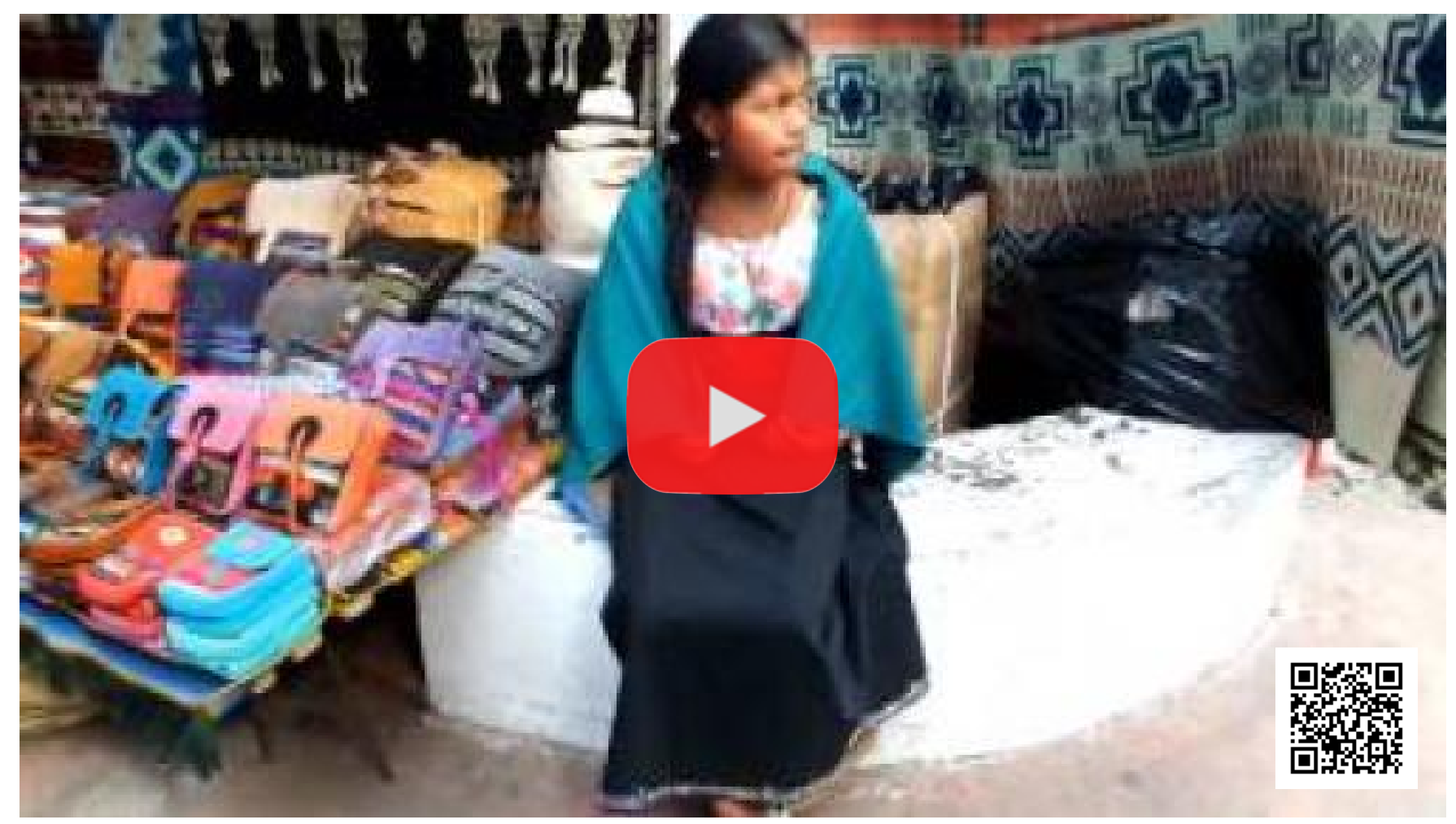


Hoy en día, APAK no solo trabaja con la cultura kichwa otavalo, tiene una asociación con una organización sueca llamada 'Tradiciones para el Mañana', que estaba interesada en el proyecto y que los ha financiado. Gracias a esto, APAK trabajó con la zona 1 de Ecuador, lo que significa no solo para el trabajo audiovisual en Imbabura, sino también en Carchi, Sucumbíos y Esmeraldas. APAK ha dado capacitaciones y conferencias a jóvenes interesados en este trabajo. En la Amazonía, se han conformado otras organizaciones audiovisuales llamadas APANAPS, donde jóvenes Kichwa, Cofán, Siona y Secoya hacen vídeos y APAK se encarga de distribuirlos. APAK tiene alianzas con la Universidad Técnica del Norte y la televisión UTV, quienes les ayudan a transmitir el programa en Imbabura, Carchi y algunas partes de Sucumbíos y Esmeraldas. Lo que APAK está haciendo ahora es tratar de encontrar nuevas alianzas con nuevos medios, otros canales, que también deseen transmitir su programa y tener una gran cobertura.

Toa también explicó la dificultad de encontrar el apoyo del Estado y de encontrar el espacio para transmitir el programa en canales de televisión públicos y privados. Ella piensa que la cultura no se vende bien en los medios, por lo que a un productor independiente e intercultural le resulta difícil encontrar el espacio. A la mayoría de la gente le gusta y adula el trabajo, pero en el momento de comprar el programa, los canales no lo quieren. Los medios no cumplen la ley del $5 \%$ de contenidos independientes 0 culturales en su programación sino buscan algo más rentable y fácil de vender.

Los medios intentan cargar a los espectadores con programas de contenido incorrecto $y$ eliminar la otra alternativa. Algo que es importante es que estas culturas están tratando de ser parte de los medios y tratar de ser escuchados, pero la mayoría de las veces los medios y ni siquiera el Estado lo respetan. La idea es construir una representación real sobre estas culturas.

Se proyecta una parte del programa que ha hecho APAK llamado 'Bajo el mismo sol'. Todas estas producciones se pueden encontrar en la página web de APAK o en el canal de YouTube. Las actividades de APAK incluyen capacitación y asesoramiento de comunicación en un contexto pluricultural. Realizan documentales, informes, cortometrajes y contenidos audiovisuales que han sido premiados en Ecuador y otros países.

Toa mencionó las limitaciones que han encontrado en el camino. En resumen, APAK es una revista cultural que ha tenido 13 temporadas, trabaja con culturas del norte del país, promueve la interculturalidad y produce todo su trabajo desde una mirada introspectiva sobre la cultura y la identidad, mostrando estas culturas no como objetos sino como culturas, como sujetos. Cuando intentan vender su producto a otros medios, la mayoría de ellos aún intentan vender estas culturas como exóticas y todo lo que las muestra diferentes no lo vale. Losmedios lo consideran producciones no rentables y tienen muy pocas propuestas de dinero. Una vez que se les ofreció 400 dólares por una temporada de 22 episodios, eso no reflejó todo el trabajo involucrado para lograrlo. Además, la mayoría de las veces los medios diseñan su propia línea de trabajo diciéndoles qué hacer y cómo, prohibiéndoles representar su cultura a su manera.

Las instituciones estatales han hablado sobre la necesidad de programas interculturales en los medios y han sido invitados a participar en foros para vender sus productos, pero finalmente lo que hizo el Estado fue crear su propio programa de televisión y venderlo libremente a los medios, convirtiéndolo en competencia injusta. Ahora, APAK es parte de la competencia de frecuencias y todavía está esperando un resultado. Entonces, lo que queda es encontrar fondos internacionales que reconozcan el trabajo de APAK.

\#PerDebate17 


\section{Conferencia: "Los desafíos de la diversidad étnica en los medios públicos"}

Bélgica se considera la prueba de la diversidad étnica en los medios públicos. Comenzó su carrera en los medios públicos como pasante, luego fue contratada y comenzó a trabajar como reportera y luego como coordinadora de noticias. Trabajando como coordinadora, estuvo a cargo de 8 periodistas, 4 en Quito y 4 en Guayaquil. Trabajó en Radio Pública, Ecuador TV y Agencia Andes. Además, con un amigo, han estado produciendo un programa llamado "Ecuador Piel de Ébano ", que es un programa de radio y televisión en el que hacen entrevistas sobre la cultura afroecuatoriana. Entrevistas sobre política, temas sociales y sobre lo que está sucediendo en el paisaje ecuatoriano como parte de este manto invisible que ha estado alrededor de su cultura durante muchos años en Ecuador.

Cuando hablamos de diversidad étnica, hablamos sobre la cantidad de culturas, nacionalidades 0 etnias grupos que viven en una región o país determinado. Ahora, después de esa definición, Belgica preguntó si existe diversidad étnica en los medios. Ella dijo que después de una investigación realizada en Ecuador en 2016, el 50\% de los ecuatorianos piensa que los medios presentan contenidos discriminatorios y un $32 \%$ piensa que las series en televisión discriminan a algunos grupos étnicos. Ahora, los medios públicos podrían ser ese cambio, ya que permite que todas las voces hablen y está disponible en el $90 \%$ del territorio ecuatoriano. Los medios públicos tienen el $77 \%$ de las culturas y nacionalidades, más grupos de diferentes sectores sociales.

Es una gran oportunidad que brinda la Universidad San Francisco para pensar sobre las formas en que la televisión establece los estereotipos y la discriminación. Bélgica dice que Ecuador es un país multiétnico, multicultural que tiene que trabajar con todos los medios para frenar esto y promover la riqueza de un país, no solo en las estadísticas 


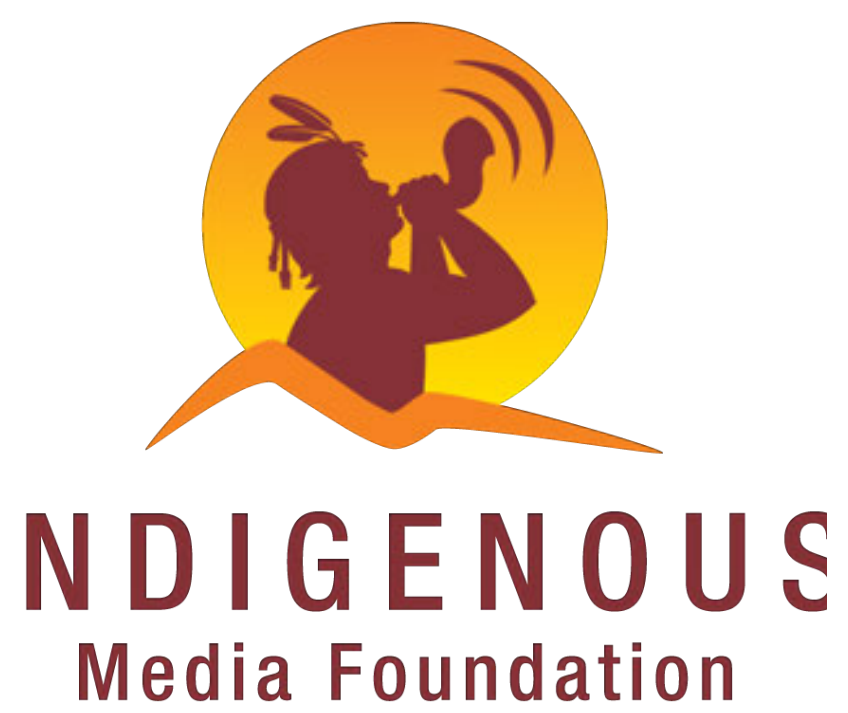

Organizaciones indígenas

Hay muchos tipos de organizaciones en todo el mundo que trabajan activamente para exigir respeto por los derechos de las minorías en este caso de los grupos indígenas.

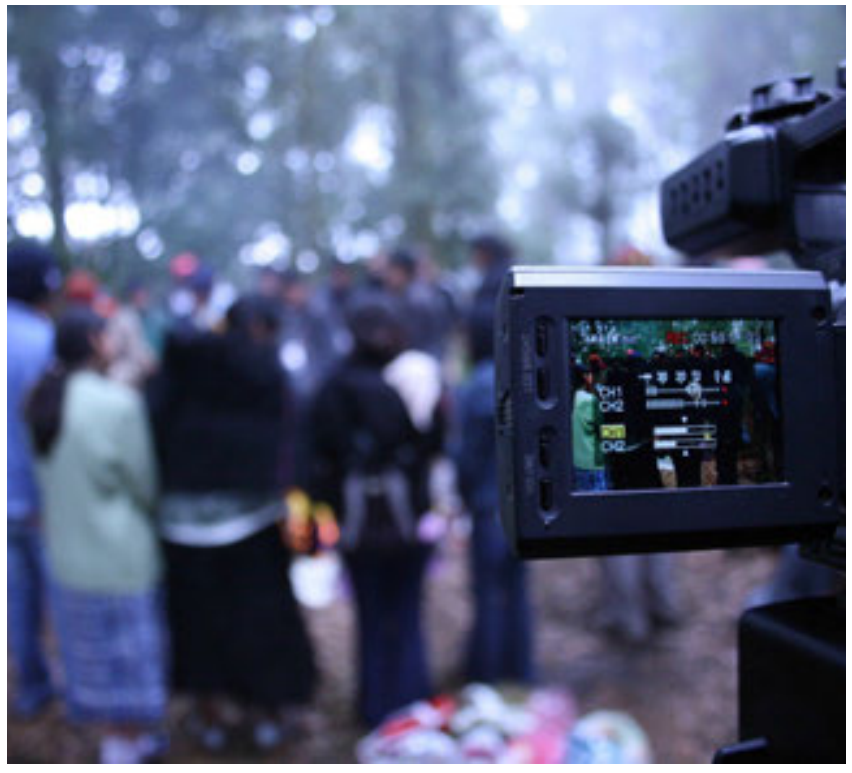

La lucha continúa

Latareade comunicar sobretemas importantes para las comunidades indígenas no es una tarea fácil, ya que han estado oprimidos por un tiempo considerable en nuestra sociedad actual. 
económicas, sino en la diversidad cultural que se puede ver en la televisión. Ella dijo que tenemos que trabajar para crear este ambiente de aceptación de todas las personas de todos los orígenes que dan forma a nuestro país.

Podemos ver esto en los medios públicos, cómo funcionan con contenidos que reflejan nuestro país. La discriminación, los prejuicios, el racismo, la xenofobia y la homofobia comienzan desde edades tempranas y los medios públicos consideran a los niños y jóvenes para hacer sus programas con el fin de eliminar estos graves problemas en la sociedad.

En nombre de los medios públicos, Bélgica nos dijo que son conscientes de que la educación y la cultura son herramientas fundamentales para el cambio social, y que han apostado en programas de diversidad y contenidos multiculturales. Un ejemplo de ejemplo. Tienen que empezar esto y promover a todos los medios y la sociedad a hacer lo mismo, ya que es una retroalimentación como todo lo que damos, recibimos. Y si dan basura en la televisión, tendremos una basura de sociedad.

Todo el mundo en el Ecuador tiene que hacer su parte con el fin de cesar la discriminación, que lamentablemente en el siglo $X X I$ sigue existiendo. $Y$ ver que los medios públicos están trabajando con diferentes grupos de nuestra sociedad es algo de lo que debemos estar orgullosos. Yes momento para que otros hagan las mismas cosas que han mostrado resultados sorprendentes.

Como medio público, alcanzan el $90 \%$ de las nacionalidades y culturas. Todos tienen su propio espacio, su propia voz y, sobre todo, están llevando a cabo la Ley de Comunicación. El artículo 36 de la Ley de Comunicación habla sobre el derecho a una comunicación

\section{Existe la idea de que un programador debe ser parte de la redacción, pero la idea no encaja bien todavía en las redacciones tradicionales}

ello es el programa afroecuatoriano "Ecuador Piel de Ébano", que es un programa de entrevistas sociales, políticas y culturales que permite que la población afroecuatoriana se sienta representada. En los medios públicos también se presentan otros grupos, por eso consideramos que todos debemos ser considerados en los medios. Entonces, Bélgica hizo otra pregunta, si pensamos que la diversidad de la que ella habla es solo el deber de los medios públicos. Sin duda, la respuesta es no. No es solo un deber de los medios públicos, es deber de todos los medios y programas de televisión nacionales representar la diversidad étnica en sus contenidos y publicaciones. Bélgica cree que todo el mundo debería hacer esto y como un medio de comunicación pública, tienen que ser el intercultural. Y así sucesivamente, para dar el espacio para tener una programación que responde a las necesidades de los espectadores, el reconocimiento de la diversidad cultural, social, étnica, lingüística, política, ideología y la diversidad religiosa. Como es sabido, la Constitución ecuatoriana aprobada en 2008 contribuye en la construcción de la identidad y un Ecuador multicultural. La gran diversidad ecuatoriana se ve en todo tipo de colectivos.

Hubo una fuerte discusión sobre por qué hay tantos estereotipos en los medios como las mujeres con tanto maquillaje o con cirugías que se muestran como un canon de belleza en la televisión. Ahora, estamos rompiendo esos prejuicios y vemos gente normal en tv. 
Los medios públicos solo apuntan a cumplir la ley (artículo 36). Sin embargo, no basta con solo aceptar la diversidad que tenemos en Ecuador, es necesario darle al pueblo de Ecuador la oportunidad de producir contenidos en su propio idioma, para poder expresar su cosmovisión, cultura, tradiciones y conocimientos. Pero, aquí está el otro lado de la moneda. Cuando hablamos de medios públicos, tendemos a pensar que es un medio estatal. Los medios públicos son importantes porque fomentan el debate y permiten la emisión de nuevos contenidos, nuevas producciones, nuevas voces para que todos tengan el derecho de expresar y crear una mayor pluralidad. Es importante decir esto para diferenciar entre los medios estatales y públicos, especialmente ahora que hemos visto ahora que el gobierno ha interferido en los medios públicos.

Cuando se refiere a los medios públicos como un medio independiente, significa que tiene que estar separado del gobierno. La participación del gobierno en el proceso de consolidación de estos medios es fundamental. Los medios públicos deben ser promovidos por el gobierno, pero no deben interferir en la producción de este, a quién entrevistar, a quién no entrevistar o con qué contenido trabajará este medio. Bélgica afirmó que el gobierno no puede interferir en la programación, no puede definir la producción o los contenidos periodísticos, pero debe impulsarlos. Como sin el gobierno, los medios públicos no existirían.

Ahora los medios públicos y gracias a ellos, todas las comunidades étnicas y puede buscar la representación de automóviles en los medios de comunicación. Todos los medios han cambiado la forma en cómo escribir noticias, cómo escribir títulos y hacer informes donde los grupos étnicos tienen más recepción. Ahora que tenemos los medios públicos para expresar es necesario tener personas que quieran hacerlo. Hay un déficit de afro, indígena, montubios profesionales en medios. Entonces, los desafíos son que hay una laca de profesionales que pueden ocupar esos puestos, la poca o menor demanda de profesionales puede hacer que la credibilidad sea menor, así como la ausencia de oportunidades en los medios privados para cumplir con el $5 \%$ de contenido intercultural. Estas son las últimas preguntas que hizo Bélgica. Ella dijo que hay 4 grandes medios de comunicación de masas en el país, 3 privados y 1 público. De 2 privados hay solo una anfitriona afroecuatoriana y en los medios públicos hay 2 , por lo que todavía quedan por resolver los desafíos.

Hay poca demanda de medios privados que no cumplan con este $5 \%$ de contenido multicultural y también podemos cuestionar a la academia para que haya más profesionales con la capacidad de hacer contenido intercultural. Porque si no sabemos cómo hacerlo, los medios no nos contratarán, entonces como academia tenemos que hacer profesionales

hagan contenidos interculturales.

Como cultura afroecuatoriana, han superado la discriminación, pero Bélgica, en sus propias experiencias, explica que han superado la discriminación, pero que está comenzando la violencia de género. En el caso de las mujeres que piensan que no pueden liderar u ocupar cargos directivos. Entonces, cuando creemos que hemos superado algo, encontramos otra barrera. Si hablamos de diversidad, debemos enfatizar la participación de grupos, nacionalidades, adultos, mujeres, LGTI, niños y jóvenes.

Finalmente, Bélgica invitó a construir una sociedad donde la discriminación no exista, y una vez que detengamos la discriminación y la violencia de género, podremos mostrar la diversidad que queremos, y necesitamos en los medios públicos y toda la televisión nacional. Porque si tenemos una sociedad preparada, demandaremos mejores y más contenidos de calidad en televisión.

\#PerDebate17 
Betsi Grabe,

Universidad de Indiana

Volver al índice - English Version

\section{Conferencia: "Cobertura de género en los medios"}

El género, dejando en claro que reconoce que cada vez más no se ve como un binario. Muchas personas hoy en día no se identifican a sí mismas a lo largo de esta separación biológica binaria de hombres y mujeres. Experimentan y se identifican a sí mismos en una escala en algún lugar entre el hombre y la mujer. Vimos esto en memes de intelecto muy bonitos, mostrados por Betsi, y una poesía profunda y significativa. Al mismo tiempo, este binario de hombre y mujer es la base de una investigación sobre la podredumbre, que nos muestra que existen preocupaciones sobre la igualdad entre los géneros biológicos de las personas que viven en todo el mundo.

Grabe mostró un ejemplo de la diferencia en la brecha de ingresos. En todo el mundo existe una enorme disparidad en

\section{"Los hombres tienen más probabilidad que las mujeres (62\% contra 38\%) de recibir créditos en periodismo"}

grandes partes del mundo. También está claro que existe una brecha en la igualdad educativa, el doble de niñas que de niños nunca comenzará la escuela y eso es una estadística mundial. También mostró algunas estadísticas bastante deprimentes sobre el liderazgo en las mujeres, y podemos ver quelas mujeres representan un porcentaje muy pequeño del gobierno. Y también, en el mundo de los medios, hay algunas diferencias de género bastante persistentes. Entonces, lo que sabemos es que los hombres son más propensos en un $62 \%$ a un $38 \%$ de las mujeres a recibir crédito por hacer periodismo. También es interesante lo que informan las mujeres sobre el periodismo, las mujeres no informan sobre política, asuntos domésticos, economía mundial, pero reportan mucho sobre cosas relativamente importantes como el estilo de vida, la educación, como un 
Betsi Grabe

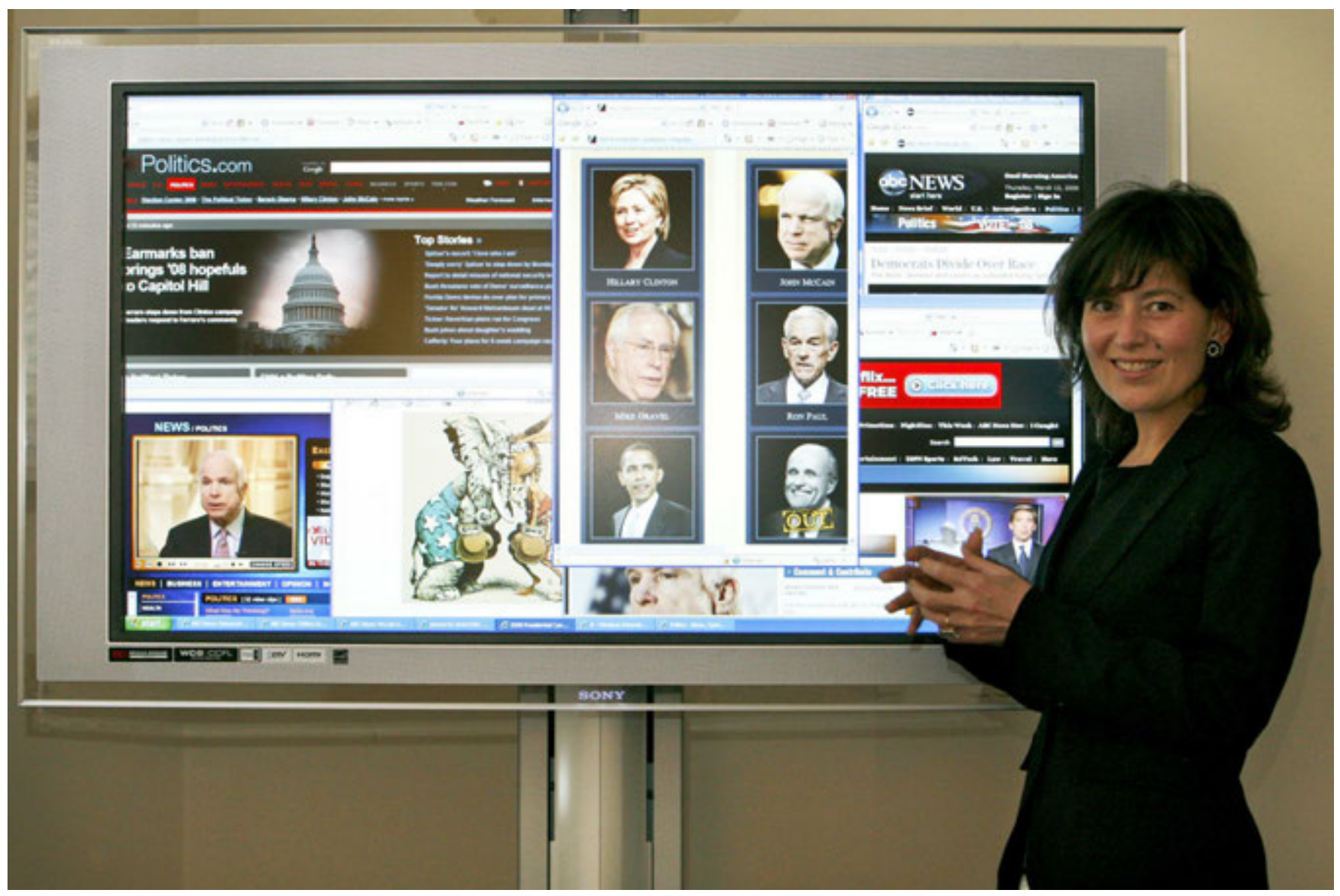

tema más femenino o la salud, poco de la ciencia, que es bastante alentador.

Betsi Grabe repasó dos estudios que ha realizado para comprender cómo los hombres y las mujeres reciben noticias, cómo la procesan y cómo dan sentido a los problemas sociales, y cómo se enfrentan a través de la información en los medios de comunicación.

El primer estudio se centra en cómo los hombres, específicamente, y las mujeres cuando miran noticias y ven anclas femeninas muy sexualizadas y lo que les sucede cognitivamente y cómo ven su profesionalismo, etc. Tradicionalmente las mujeres en los Estados Unidos han tenido un momento muy difícil para ser empleadas como presentadoras de noticias, y lo que hemos visto es que las mujeres que terminan siendo noticias anclan su apariencia, su apariencia física es bastante andrógina, su cabello es corto, lleva chaquetas. $\mathrm{Y}$ luego

\section{"Empezamos a ver una sexualización de periodistas"}

sucedió algo diferente, comenzamos a ver una gran sexualización de las periodistas femeninas, mucho escote, mucho maquillaje, joyas y parte de esta tradición ha cambiado drásticamente en los últimos diez o quince años.

También pudimos ver muchos cuerpos de mujeres en las noticias de televisión, donde normalmente usan un tipo de hombro de cerca, ahora vemos cuerpos completos de mujeres, por lo que incluso el diseño del escenario, las estaciones de noticias de transmisión han cambiado para revelar más cuerpos de mujeres. Esto fue algo que Grabe 
consideró importante investigar, este cambio radicalen la forma en quelas mujeres aparecen en las noticias.

Al principio, puede parecer una simple cuestión intentar dibujar globos oculares en la pantalla y atraer espectadores más grandes y ganar más dinero publicitario. Pero Grabe sospechaba que requería más reflexión, para explicar en qué consiste el atractivo de las mujeres y cómo podemos medir eso y cómo jugarlo en un noticiero de televisión.

Lo que sabemos por investigación en psicología evolutiva es que en más de 40 países del mundo, los hombres clasifican sistemáticamente a las mujeres en una relación muy clara entre la cadera y la cintura como sexualmente atractivas, lo que significa que la relación de cadera a cintura es el único predictor de una mujer atrae la diferencia sexual. Todo se trata de la diferencia entre una medición de la cintura y la cadera, por lo que la diferencia entre eso es una relación alta entre la cadera y la cintura, y eso es más atractivo. Básicamente se trata de una forma de manzana vs figura de forma de pera. Lo que los investigadores también encontraron, y esto es bastante controvertido, explica Grabe, es que las mujeres que tienen la figura del reloj de arena, o la forma de pera, se clasifican sistemáticamente en una serie de variables y físicamente más saludables y también más fértiles en términos reproductivos. De este modo, el fisiólogo evolutivo concluye que los hombres de alguna manera tienen esta predisposición sin saber que prefieren los tipos de cuerpo en las mujeres que están mejor posicionadas para la capacidad reproductiva.

Hay dos cosas que lo hacen polémico. Una cosa es que estos son patrones muy amplios, por lo que son consistentes en todas las culturas y también están dentro de la varianza cultural. La segunda cosa es que hay muchas mujeres con figuras en forma de manzana que tienen un marido amoroso y se reproducen muy bien. Solo para profundizar un poco más, para mostrar la persistencia de esta relación entre la cadera y la cintura, incluso en nuestras primeras reproducciones culturales. Grabe mostró las figuras de Venus encontradas en todo el mundo, algunas de ellas datan de entre 9 y 31 mil años, podemos ver claramente la relación entre la cadera y la cintura en estos pequeños artefactos de los cuerpos femeninos. Pero incluso con cierta predisposición biológica, está claro que la cultura atormenta y refuerza esta preferencia por una relación entre la cadera y la cintura clara en los cuerpos femeninos. Va desde estos artefactos, incluso en Ecuador, la pintura europea, la moda victoriana, con la ayuda de corsés para enfatizar las relaciones entre la cadera y la cintura, en grados muy extremos. Una práctica bastante criticada por los espectáculos de modas modernas y el arte feminista.

Grabe reclutó a cuatrocientos estudiantes participantes y la mitad de ellos eran hombres y la otra mitad mujeres. $Y$ eligió a una estudiante que quería ser periodista y presentadora. Y lo que hizo fue sexualizarla tan levemente en una condición y desexualizarla en la otra condición. Incluso allí, la diferencia fue muy pequeña. Todo se reduce a solo tres cosas cambiadas. Primero, se ajustaron la chaqueta para mostrar la relación entre la cadera y la cintura, le pusieron un lápiz labial rojoe incluso le pusieron algunas joyas, y en la otra condición, ella no tenía ninguna de estas.

Pusieron a prueba las percepciones de las personas sobre su profesionalismo, la percepción de la gente de cuán competente sería para informar sobre diferentes tipos de noticias desde la guerra a temas más femeninos como la educación. También probaron las memorias de las personas por el contenido de las noticias que presentan. Lo que encontraron fue que en el profesionalismo, los participantes masculinos calificaron la versión sexualizada de esa presentadora como mucho más profesional que la no sexualizada. Las mujeres 
participantes la versión sexualizada como menos profesional.

Entonces, puedes ver la diferencia de género emergente. $Y$ esto es bastante contradictorio, cree Grabe. A pesar de que los hombres calificaron al presentador sexualizado como más profesional, pensaron que no era competente para informar sobre cosas o temas pesados de noticias como guerra o informes políticos. Y finalmente, en memoria, los hombres no podían recordar gran parte del ancla sexualizada. Los hombres no pueden prestar atención al contenido de las noticias cuando un presentador sexual lo presenta.

En resumen, los hombres se ven muy afectados por la sexualización de reporteros y presentadores. Clasifican a los presentadores sexualizados como más profesionales y, al mismo tiempo, califican su competencia en el contenido de noticias duras como muy baja y no pueden recordar nada de lo que informan. Las sugerencias de Grabe aquí son que todas las mujeres periodistas o que quieran ser periodistas serían las siguientes. Si estás interesado en una carrera larga y construyes tu credibilidad como periodista, mantente alejado de la sexualización de tu apariencia, no solo en el aire, sino en todas las noticias.

El segundo estudio se centra en las audiencias femeninas y en cómo las mujeres procesan y conservan noticias, y Betsi Grabe en particular estaba interesada en descubrir cómo las mujeres responden a las noticias negativas, noticias profundamente negativas. Nuevamente sabemos por la psicología evolutiva que nosotros, como seres humanos, somos lo que se llama alambre duro de estímulos negativos. Esto también se conoce como el sesgo de negatividad. $Y$ los argumentos son, literalmente, que nacemos con esto y es parte de nuestro pasado evolutivo, así que sobrevivimos como especie porque éramos muy buenos para responder a los estímulos que amenazan nuestra vida a nuestro alrededor. Hay dos respuestas básicas a los estímulos altamente negativos, ya sea enfoque o evasión. Curiosamente, las noticias por definición en el mundo son negativas.

Las noticias funcionan en gran medida como un sesgo de negatividad en los seres humanos. Al mismo tiempo, sabemos que las mujeres informan en todo el mundo que entre el $45 \%$ yel $72 \%$ de las mujeres dicen que no les gustan las noticias porque son muy negativas. También sabemos que este sesgo de negatividad funciona a través del género. Las mujeres son mucho más sensibles a la negatividad, exhiben y evitan la respuesta. $Y$ esto tiene mucho sentido en términos de supervivencia. La supervivencia de los niños depende mucho más de la supervivencia de una madre que de un padre. Entonces, tiene sentido que la mujer evite el peligro.

Grabe estaba interesada en probar cómo la negatividad en las noticias podría afectar a hombres y mujeres cuando reciben noticias. Ella aceptó que las noticias eran negativas, pero incluso en las noticias más negativas a menudo hay cosas realmente positivas en las que los periodistas pueden centrarse. Un ejemplo que Betsi Grabe usó fue una historia de la ocupación militar de EE. UU. En Medio Oriente, una historia sobre los hombres y mujeres que prestan servicio podría centrarse en su descripción negativa diaria de ser un soldado, o también puede haber un foco entre la relación de las personas y soldados, lo cual es más positivo. Otro ejemplo, en una historia sobre la obesidad adolescente podría contarse una historia y solo enfocarse en la negatividad del adolescente pasivo que se alimenta, o enfocarse en algunas de las soluciones, como programas que involucran a adolescentes activos y juntos, o en historias sobre desastres uno podría simplemente enfocarse en la devastación absoluta que es extremadamente negativa, 0 uno puede enfocarse en cómo las comunidades se juntan y se ayudan entre sí.

Grabe realizó un experimento para ver cómo este diferente encuadre de las noticias podía afectar a hombres y mujeres. Reclutó a 75 
participantes para este estudio, la mitad hombres, la mitad mujeres. Tomaron 8 noticias inherentemente negativas y las empaquetaron como si tuvieran solo imágenes y descripciones negativas, luego hicieron otra versión que incluía algunos elementos positivos y soluciones. Algunos de los hallazgos fueron la excitación, variable muy interesante para saber qué sucede en el cerebro, e incluso tenían técnicas para medir la excitación durante la visualización de noticias. Las mujeres estaban más excitadas por las noticias positivas y los hombres más excitados por el lado negativo de las noticias.

En términos de memoria, memoria de reconocimiento, pudimos ver que las mujeres no recordaban gran parte de las noticias negativas en comparación con las noticias positivas. Otra medida fue la comprensión que mantuvo el patrón de las mujeres comprendiendo más las noticias positivas de las noticias negativas.

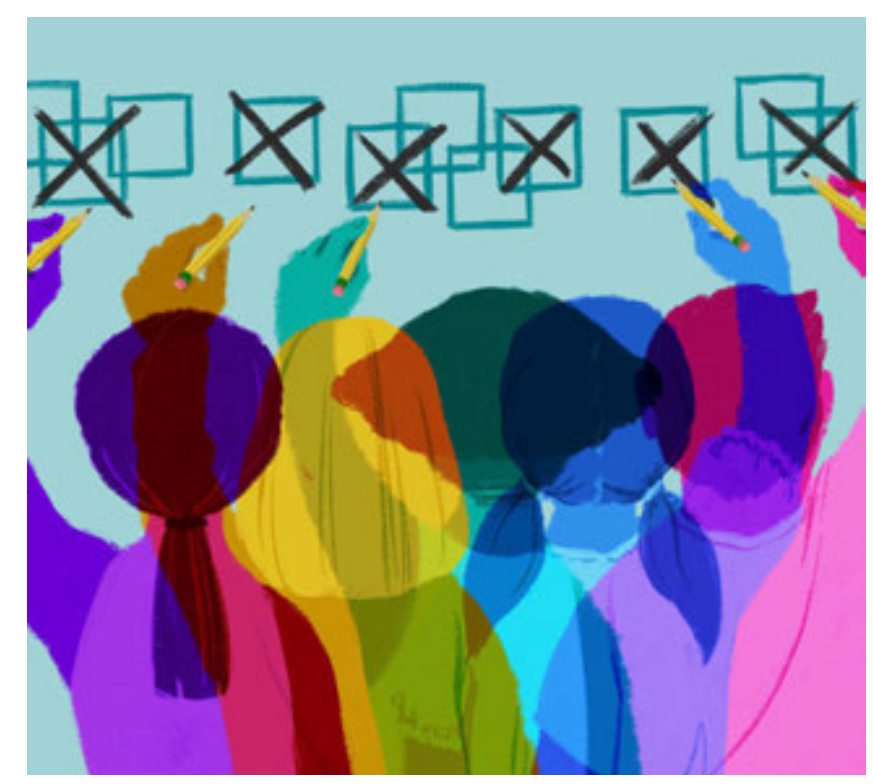

Un trabajo continuo

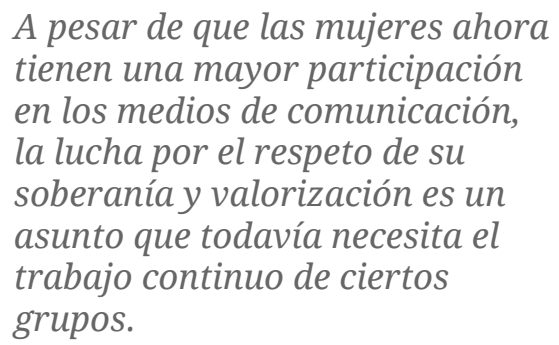

A pesar de que las mujeres ahora tienen una mayor participación en los medios de comunicación, la lucha por el respeto de su soberanía y valorización es un grupos.
En resumen, esto es lo que les ha sucedido a las mujeres en este estudio experimental. Las mujeres se ven muy afectadas por las noticias de enfoques más positivos y es muy claro que un marco más positivo aumenta su excitación, aumenta su memoria de reconocimiento y aumenta su comprensión de las noticias. Si nos importan las noticias como una forma de informar a los ciudadanos de una democracia, Betsi cree que los periodistas deberían prestar más atención a las formas en que enmarcan las noticias. Es evidente que las mujeres serían consumidoras de noticias activas y felices si las noticias pueden proporcionar más soluciones, perspectivas orientadas a los problemas sociales. No se está abogando por buenas noticias porque eso nunca sucederá, pero sí se está pide que los periodistas piensen detenidamente y encuentren estos elementos de solución positivos en cualquier problema social que exista.

\#PerDebate17

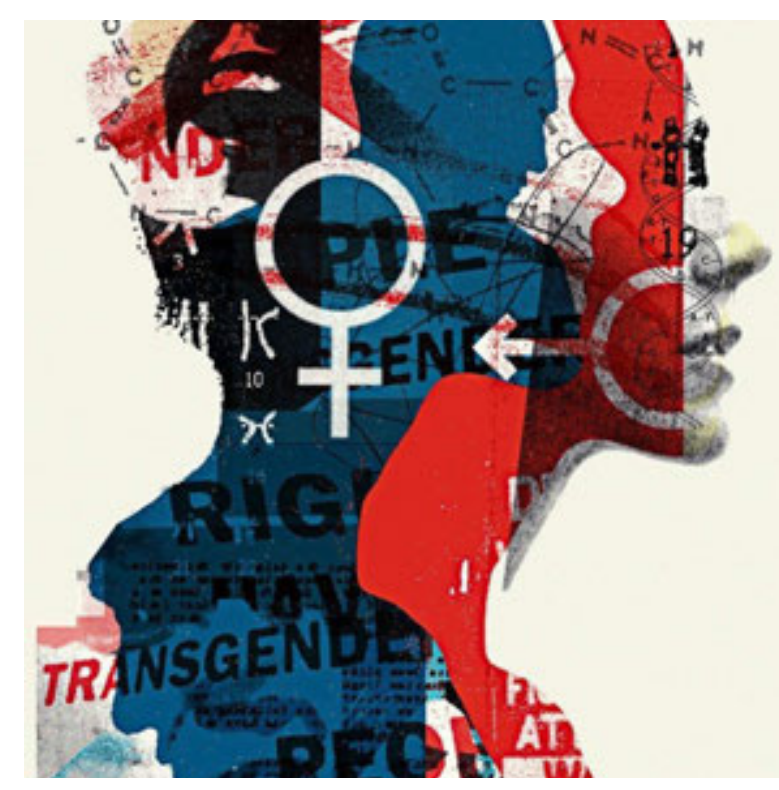

Anarquía y libertad

Lo que las mujeres necesitan cuando su participación en los medios de comunicación es la soberanía de los métodos de decisión y desconexión, el control cada vez más obsoleto que resta la importancia de su participación en diversas áreas. 


\section{Foro,}

Participantes: Betsi Grabe: directora de Plan V, revista digital; Nydia Pesantez: Journalism Resea Moderador: Santiago Castellanos: director del COCOA

Volver al índice - English Version

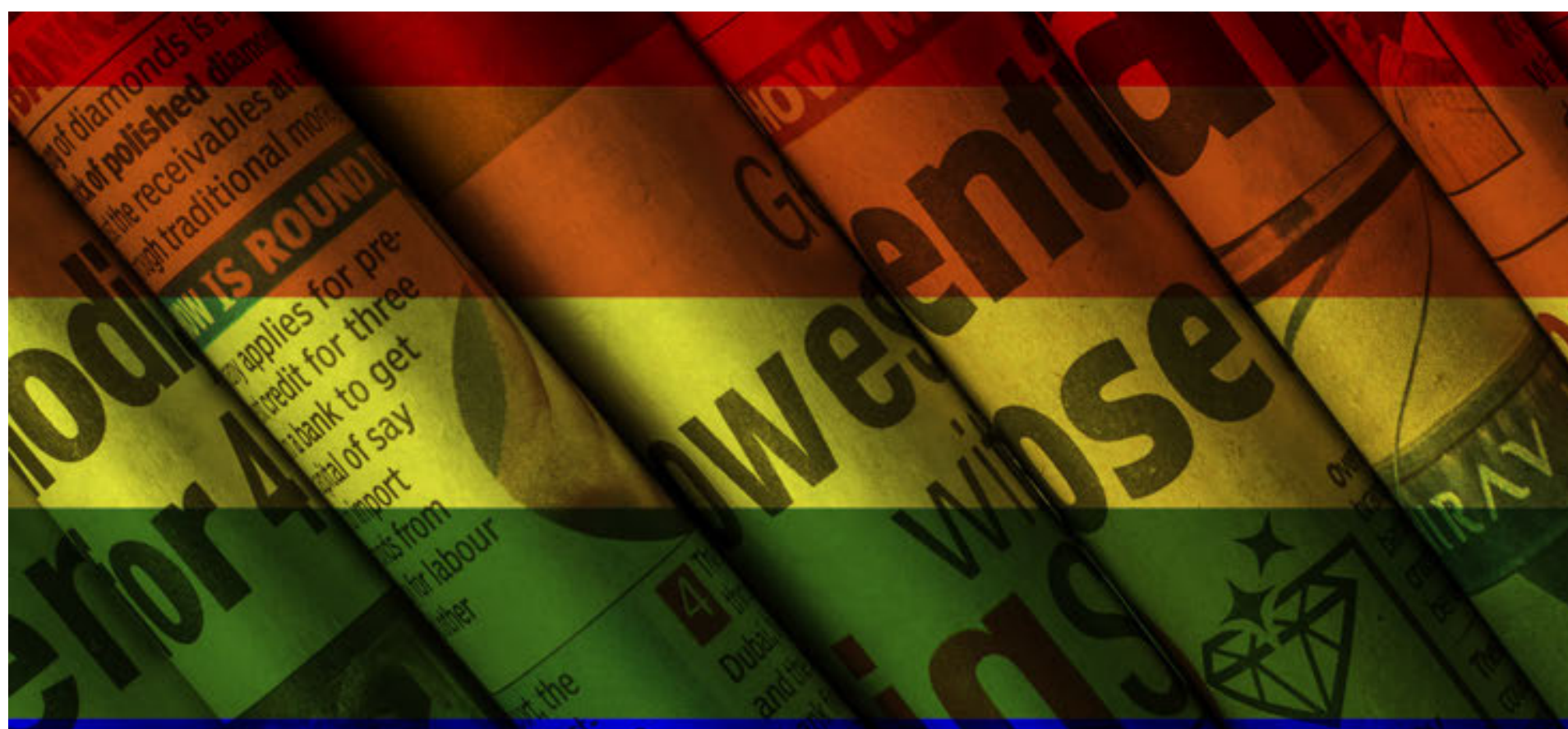




\section{"Investigación académica en género y prácticas de medios"}

Santiago Castellanos: Betsi ya nos ha dado un panorama de lo que está pasando en Estados Unidos con la investigación con los presentadores de televisión y me gustaría preguntarle a Betsi, si ella ha visto que en estos años hemos retrocedido $¿ \mathrm{O}$ si algo ha sido sexualizado que no era antes? ¿Incluso qué cambios positivos ha visto en las relaciones de género en los presentadores de televisión, y también le pregunto cómo ve el género en el periodismo? ¿Podemos comenzar con Nydia?

Nydia Pesantez: Bueno, la percepción general coincide con lo que la investigación ha encontrado sobre las relaciones de género en los medios. Hay algunas investigaciones muy interesantes hechas a nivel internacional y nacional. De hecho, hablaré sobre dos investigaciones que he seguido, una lleva 14 años de investigación, llamada Media Monitoring, realizada por la Asociación Mundial para la Comunicación Cristiana y una del Observatorio de Comunicación de Ciudadanos de Cuenca. Ambos hacen una investigación rigurosa de los programas de noticias, publicidad y entretenimiento. En el caso de la presencia de mujeres en las noticias, representan en un número global el $24 \%$ de la imagen en las noticias. Esto significa que somos el $50 \%$ de la población, pero nuestra presencia en los medios es del 24\%, pero cuando hablamos de trabajos más específicos, las mujeres en los medios con liderazgo en la academia alcanzan el $11 \%$.

Tomando esa información hecha en 2015, las mujeres no han progresado. De hecho, cuando hablamos en nuestro entorno, podemos decir que las cosas ya han cambiado, y que los hombres y las mujeres se encuentran en igualdad de oportunidades. Pero algunas cosas han cambiado, ahora tres mujeres están hablando con el decano sobre género algo impensable hace 30 años, pero el corazón del problema todavía no ha cambiado. Si hacemos el análisis e investigamos las fuentes, podemos encontrar la evidencia. 
Nelly Valbuena: Efectivamente, creo que el cambio ha sido muy lento. En el campo de la investigación, tenemos algunos trabajos que de una forma $u$ otra han hablado sobre el género, pero no lo han hablado sustancialmente, por ejemplo, en el campo del periodismo. Podemos ver algunas investigaciones de México y Argentina sobre la diversidad sexual, pero no se ha convertido en contenido para los medios. Quiero decir, los periodistas todavía no hablan de eso e instintivamente estamos reproduciendo las fuentes como la ciencia, la economía y la política que se han determinado en un $70 \% \mathrm{u}$ $80 \%$ en fuentes masculinas, hay más credibilidad en los hombres en estos temas. En el caso de las mujeres, cuando hablan sobre los temas, se les piden las cosas más triviales, las menos importantes y terminan hablando de temas livianos, cosas de las que nunca se habla si la fuente hubiera sido un hombre.

Todavía estamos disminuyendo la presencia de mujeres y la construcción de cosas incluso desde la fuente. Para los temas sociales y humanísticos, preferimos tener una fuente femenina, porque esos temas tratan más sobre la sensibilidad de las mujeres. Hay una gran brecha entre la comunicación como campo interdisciplinario y el periodismo.

Betsi Grabe: Estoy totalmente de acuerdo con sus observaciones, hay tantos datos que respaldan eso y lo que más me preocupa es que cuando vemos el nivel de entrada en el periodismo vemos que muchas mujeres ingresan al periodismo. En las universidades vemos a muchas mujeres en el entrenamiento periodístico y eso significa que algo sucede en el mundo cuando las mujeres salen y quieren ser periodistas. Mi sentido es mundial cuando las mujeres ingresan al periodismo profesional y con el tiempo desaparecen. Con la aparición del periodismo ciudadano, un entorno de noticias más abierto en línea, esto podría cambiar lentamente.

Santiago Castellanos: ¿Qué se puede hacer? Podemos denunciarlo, pero parece que el viejo modelo de hacer noticia era muy masculino o necesitaba un modelo masculino en las noticias. Entonces, ¿cuáles son las posibilidades de rehacer el mundo de las noticias de una forma $u$ otra 0 , cambiarlo para hacer que más mujeres puedan participar y tener éxito? ¿Cuáles son las esperanzas para todas las mujeres que están aquí hoy y quieren ser periodistas?

Nydia Pesantez: Los seres humanos son un producto de la evolución, y nuestra sociedad junto a nosotros tendrá que evolucionar. $Y$ esta es la evolución de nuestra sociedad, la garantía de la igualdad. Si no avanzamos, la especie desaparecerá. Las posibilidades son todo o nada. Tengo la esperanza y confío en todas las posibilidades porque, por ejemplo, el lenguaje es un producto del pensamiento $o$ de lo que sentimos, y ese lenguaje se expresa en la narrativa, en el arte, en la forma en que hacemos una noticia. Efectivamente, la corriente principal de la misma es masculina, no porque el periodismo o la comunicación sean agentes de los procesos sociales, sino porque son parte de la sociedad.

Todo lo público se ha construido sobre una perspectiva varonil porque lo masculino era lo único en el ámbito público. Estas últimas décadas son aquellas en las que las mujeres comenzaron a hacerse públicas y han comenzado a incorporar esta nueva perspectiva. Por lo tanto, tenemos todas las posibilidades, pero tenemos que entender que el cambio no va a ser rápido, llevará tiempo, pero no significa que tenemos que superar el flujo esperando que el cambio se produzca naturalmente, porque ganó. Dependerá de nosotros, de cuánto aceleremos esta transformación, específicamente en los medios. Por lo tanto, los hombres y las mujeres deben comenzar a hacer el cambio. Usted es la base del cambio.

Nelly Valbuena: Estoy bastante cansada de ser paciente. Creo que es suficiente y considero que todavía tenemos una fuerza muy fuerte del patriarcado en los medios. Quiero decir, 
los medios siguen siendo obedientes a una cultura de patriarcado que es muy difícil de transformar. Sin embargo, todavía tengo esperanzas porque no quiero ser la pesimista del foro. Es el momento de incorporar más carreras de comunicación con un enfoque de género y empezar a ver la violencia de género con otro punto de vista. Incluso cuando salimos a realizar nuestro trabajo o cuando diseñamos los temas porque no hay una manera más efectiva de hacer que los medios incorporen este tema, lo hago yo como un profesional que lo propone. Si no lo hago, mi editor que ha trabajado durante muchos años como resultado de una cultura de patriarcado no me permitirá hablar sobre este tema.

Si vengo con estos nuevos elementos y esta nueva visión de hacer noticia, podríamos comenzar a hacerlo. En Colombia tenemos esta cita de Maturana, el entrenador de nuestra selección de fútbol dijo que había maneras de marcar en algunas redacciones periodísticas. Creo que debemos puntuar haciendo nuevas propuestas de temas a nuestros editores. Ese trabajo ahora está por hacerse, es un trabajo para la academia y los escritores para proponer nuevas ideas llenas de conocimiento sobre el enfoque de género, la diversidad étnica, que podemos tener en cuenta en la agenda mediática.

Betsi Grabe: Históricamente, si seguimos por todo el mundo la historia de las noticias y no soy historiador, cuando leo esto sobre cómo llegaron las noticias, lo que vemos es muy persistente, esa noticia fue creada por hombres para hombres. Las mujeres fueron excluidas desde el principio. Tanto como trabajos nuevos como audiencias de noticias. $Y$ eso ha estado sucediendo durante unos cientos de años en todo el mundo, por lo que mi paciencia también se está agotando. $Y$, sin embargo, sé que tomará persistencia, capacidad de recuperación, esfuerzo para cambiar esto. $Y$ quiero decir que este no es el trabajo de las mujeres para hacer el cambio. Las mujeres necesitan hombres que las ayuden, no porque sean demasiado débiles para hacerlo, sino que deben ser un esfuerzo cruzado de género.

Cuando echo un vistazo a la Universidad de Indiana y miro a los jóvenes que están inscritos en nuestros programas, tengo la enorme esperanza de que su generación marque una gran diferencia. Por alguna razón, no ves este género binario tan claramente como nosotros y eres más fluido cuando piensas en cosas, que algunos de nosotros, en nuestra generación. Por lo tanto, creo que, en este frente de género, usted es la generación que realmente se adelanta y nuestra paciencia valdría la pena.

Santiago Castellanos: El siguiente tema es algo que debe estar allí y Bélgica ya nos ayudó a mencionarlo. Ella dijo, a pesar de que, hay algunas diferencias en las etnias en los medios, al menos en nuestro país. El gran tema ahora es la violencia de género, entonces, como periodistas o investigadores de periodismo, me quedé con dos aspectos importantes de los que hablar, primero la violencia de género en el entorno laboral, pero también cómo se representa en los medios. ¿Qué nos puedes decir sobre eso? Especialmente, ahora que tenemos mujeres que denuncian la violencia de género en todos los medios como Hollywood y el cine.

Nydia Pesantez: Efectivamente, esto abarca dos ámbitos. La violencia dentro de los medios de comunicación, dentro de su propio trabajo y entre las relaciones de medios y las mujeres periodistas. Esto es mucho menos denunciado porque no tenemos tantas estadísticas. Por ejemplo, en la ONU es mucho menos denunciado que periodistas mujeres a periodistas hombres, seguramente porque están en un medio de comunicación. Ahora, el enfoque de la violencia ha sido desastroso. En este último año hemos podido ver un cambio, pero este cambio no se está haciendo con un cambio de conciencia en el trabajo, sino porque una presión social y legal y nuestro marco legal a pesar de que apoya la igualdad formal, me refiero al uno escrito, no se traduce 
necesariamente en la igualdad real. Una de ellas es la violencia y, durante décadas, los medios han representado el crimen contra las mujeres como el periodismo sensacionalista y hay temas que no afectan a la política pública. Son los temas que se venden poco, no son los temas que atacan.

Es gracias a este nuevo enfoque de género que podemos ver los cambios en los medios. Además, este cambio se ha realizado lamentablemente gracias al gran número de víctimas en nuestro país, que han despertado la curiosidad social y académica. En la ONU, cuando un periodista acude con preguntas, son más profundas, más relacionados con las relaciones de viday de poder. Entonces, vemos pequeños cambios, cambios importantes que pueden marcar tendencia. Ahora, también es un deber de la sociedad exigir un cambio en las tendencias, dejando de ver ciertos programas y periódicos, de la forma en que los medios se dan cuenta de quién está consumiendo y quién no está de acuerdo con la forma en que representan la violencia. Los medios tienen que ser los que crean masa para revisar el contenido que los medios ofrecen.

Hay cambios en la forma en que abordamos la violencia, hay periodistas que han comenzado a cuestionar esta violencia y criticar el sistema, como Roberto Aguilar, de una manera muy frontal. Pero hay algunos periodistas que todavía abordan la violencia como las noticias sensacionalistas, naturalizando esta problemática en el imaginario social. Si continúas y preguntas: las mujeres pueden provocar violencia e incluso su propia muerte, la gente responderá que sí, absolutamente. Todavía pensamos que las mujeres son propiedad de los hombres como pareja o familia. En nuestro país el incesto es un tabú, no está siendo tratado y las sociedades lo toleran porque se dice que, si un padre puede mantenerlos y hay un hombre en la familia, él tiene el derecho. Ese tipo de pensamiento es parte de la normalidad de nuestra sociedad y esos son los que deben investigarse y buscar las causas de por qué esto todavía está sucediendo en el siglo $X X \mid$.
Nelly Valbuena: En 2013-2014, hicimos un libro con Humanas Corporación, Universidad Andina Simón Bolívar y la Universidad Salesiana, como resultado de un observatorio de medios de comunicación, necesitamos observatorios de medios de género en una violencia contra las mujeres porque es la única forma de saber cómo se ha hecho el periodismo. Necesitamos verificar el trabajo que estamos haciendo, necesitamos cuestionarlo y tener los elementos para transformarlo y mejorarlo.

En ese estudio pudimos ver que hemos avanzado en algunas cosas, que efectivamente las personas no están usando los títulos de una noticia sensacionalista, eso ha cambiado un poco, pero en el momento en que revisamos el cuerpo del informe todavía vemos cómo estos estereotipos se mantienen para hablar sobre esta violencia. Y lo que es más grave es cómo se justifica esta violencia, quiero decir que de alguna manera las mujeres estaban buscando que eso ocurriera, ya que ella era la única responsable de la muerte en manos de su esposo o compañero de amor. Nos hicieron pensar que los medios han cambiado gracias a la Ley de Comunicación, aquí en Ecuador. Creo que la ley por sí misma no hace que las cosas cambien. Los cambios deben ser revisados por nosotros, periodistas. Por ejemplo, estaba muy preocupada por la forma en que se trató el caso de Karina del Pozo en los medios. La prensa hizo horrores con ese contenido, por lo que tenemos que volver a los observatorios como una forma de transformación y cambio.

Betsi Grabe: Hay varias cosas que encuentro confusas y de gran preocupación en torno a la idea de la violencia de género y los medios. Si observamos crímenes distintos en el mundo físico, sabemos que las mujeres son mucho menos que los hombres para convertirse en víctimas de la violencia. Al mismo tiempo, las mujeres son desproporcionadamente más 
vulnerables a la violencia sexual que los hombres. Los medios prestan mucha atención a contar historias de mujeres como víctimas. $Y$ creo que las horas extraordinarias hacen que las mujeres crean que son débiles y que, en última instancia, nuestra identidad es victimismo. Al mismo tiempo, me parece muy bueno que las mujeres estén tomando medidas de asalto y exponiendo su victimización en las redes sociales, no estoy diciendo que encuentre un buen movimiento. Hay otra cosa que también me parece inquietante $y$ eso es si miramos la investigación sobre este supuesto mito de la violación. La investigación dice que solo un porcentaje ligeramente mayor de hombres cree en el mito de la violación que las mujeres. Y el mito de la violación está alrededor de la idea de que cuando una mujer dice que no, que en realidad quiere decir sí. Entonces, es extraño para mí entender cómo preocupación excesiva por conocer la naturaleza del victimario como lo que le sucedió en la infancia. En Colombia tuvimos el caso reciente de un arquitecto de una familia muy conocida que secuestró y abusó sexualmente de una niña pequeña y la mató. Contando los titulares que fueron publicados alrededor de la niña no había cantidad inferior a la publicada en todo el victimario. Además, los medios cubrieron la identidad del victimario, inicialmente.

Público: Tenemos una mayoría de estudiantes que son mujeres, casi un 60 o $70 \%$ de mujeres estudiantes. Eso debe generar un cambio con el tiempo. Como, por ejemplo, lo que Betsi habló sobre la ropa exagerada en las mujeres y apenas puedo pensar en más mujeres siguiendo este pensamiento. ¿Qué necesitamos para detener eso? ¿Por qué parece continuar?

\section{Hay un elemento que Paulo Freire llamó "La internalización del} opresor". Donde las mujeres que no han podido abrir su conciencia para descubrir por qué hay diferencias entre hombres y mujeres y alcanzar cierto punto de poder o los medios de comunicación

nosotros, como mujeres, nos hemos convertido en creer en el mito de que cuando decimos que no queremos decir que sí, quiero decir que está más allá de toda idea, no entiendo que la investigación sea muy clara al respecto. $Y$, por supuesto, yo tengo que mirar el país donde vivo, los Estados Unidos, y buscar un hombre que acusan de al menos tres violaciones y ahora es presidente. Si miramos el comportamiento electoral de las mujeres en la última elección de los Estados Unidos, más mujeres que tradicionalmente votan como demócratas votaron por Trump, que las mujeres que son republicanas tradicionales que votan por Clinton. Trump ganó porque las mujeres demócratas votaron por él.

Nelly Valbuena: Los medios le dan más importancia al victimario que a la víctima. Quiero decir, existe una
Nydia Pesantez: No es automático. Ser mujeres nacidas no significa nacer con conciencia de género. Como nacer pobre no significa ser consciente de la clase. O nacer afro o indígena no significa tener una conciencia étnica o racial. Vivimos en una sociedad que desde que nacemos, nos determina. En el caso de la zona urbana y occidental, los colores, los juegos, las formas de crianza son binarias. Por ejemplo, dado que a las mujeres pequeñas se les dice que se sienten de cierta manera o que tengan una voz baja, y en el caso de un acoso sexual, ¿nos preguntan por qué no gritaste? Después de ser educado para estar tranquilo siempre. Entonces, no es fácil.

Hemos dado el paso a la humanidad para vivir en igualdad. Lo que pedimos, no es ayuda, sino que den el paso para que la humanidad genere estos cambios. Es un deber común, pero no un favor, un deber conjunto para mantener a la 


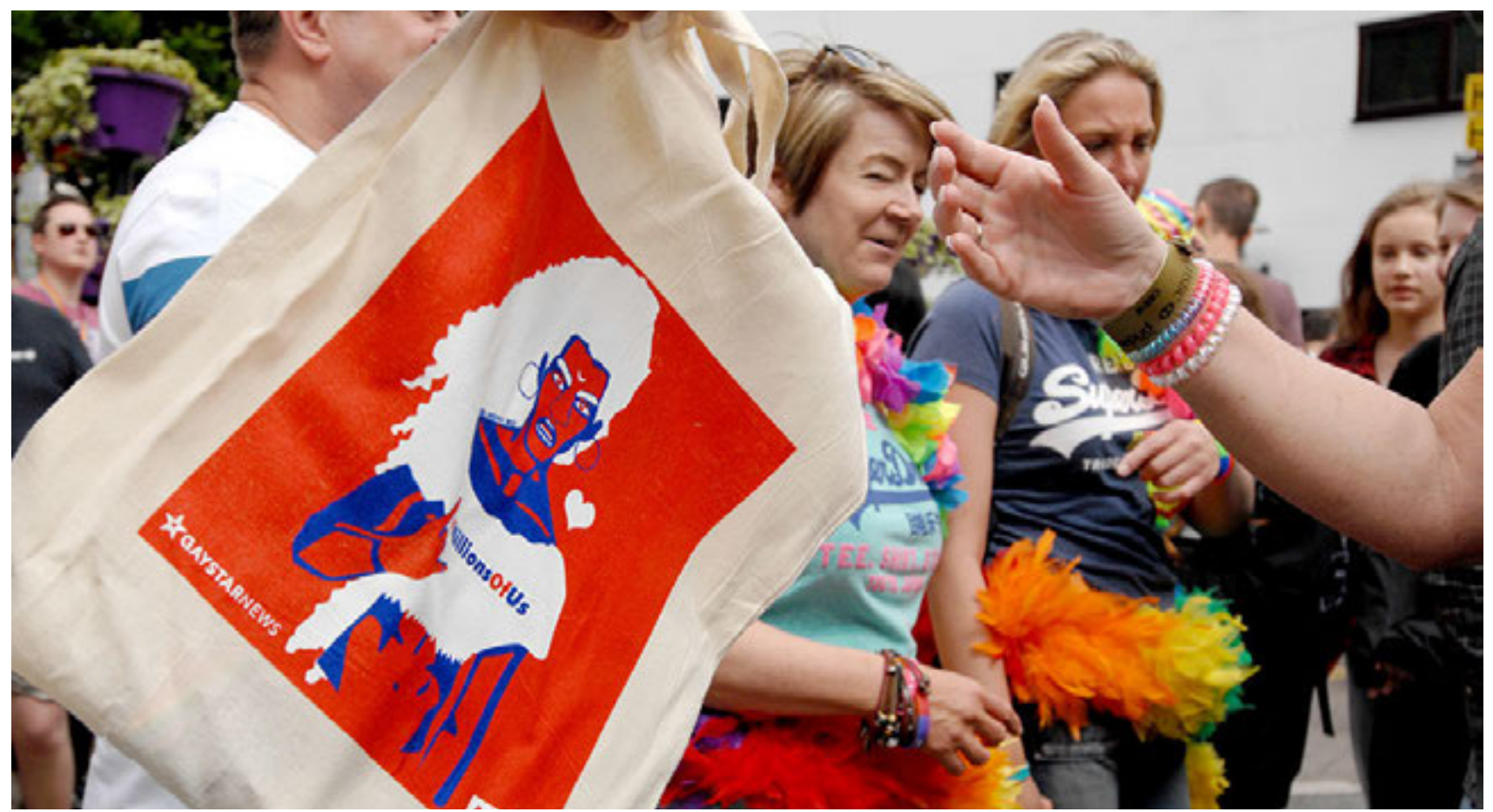

especie humana. Porque la forma en que vamos nos está llevando a la destrucción y los fundamentos básicos son las relaciones de quién hace posible la procreación de esta especie, hombres y mujeres. Si no empezamos a ver las cosas de otra manera, no podríamos sobrevivir. Apenas tenemos 130 millones de años como Homo Sapiens, el cosmos tiene 14 mil millones de años, el planeta Tierra tiene 4 mil millones de años. Somos un suspiro. Creemos que estamos aquí para siempre, pero depende de nosotros.

Nelly Valbuena: No es nuevo que las carreras de comunicación tengan más mujeres. Quiero decir, estudié en la década de los 80 y éramos más mujeres que hombres, y nuestro decano era un hombre y la directora académica era una mujer, las posiciones de logística eran mujeres, pero los hombres siempre estaban en los cargos de decisión sin enfoque de género. Todos ustedes tienen un decano que tiene un enfoque de género, Eric es sensible a los problemas de género, pero nosotros no. Y no tuvimos este espacio de discusión y creo que eso es algo que ha cambiado en las carreras de comunicación. Y las mujeres pudieron tener más opciones educativas. Pero esto no cambia nuestras condiciones de trabajo, nosotros no ganamos como los hombres, no tenemos el mismo acceso a los puestos de decisión y de poder y cuando lo hacemos, somos efectivamente las mujeres que no tienen el enfoque de sensibilidad o de género y se continúa con estas prácticas de patriarcado.

Por lo tanto, es muy difícil porque las mujeres también se han transformado por el patriarcado y el control masculino. Hemos sido tocados de una manera muy compleja, la forma en que nos ha hecho ser parte de esto. Hemos cambiado, pero aún hay mucho por cambiar.

Betsi Grabe: Honestamente, me hizo pensar en lo que dijiste. Hay un estudio que he hecho sobre corresponsales políticos femeninos. Estas son mujeres que trabajan en los bits periodísticos más masculinizados. Por lo tanto, este es un ambiente muy hostil y muy difícil de trabajar y se les dice en sus entrevistas, es anónima, por lo que te puedo decir quiénes son, que tienen que ser más masculino que los chicos que estaban trabajando, literalmente deben renunciar a ser mujeres y mujeres en su identidad y ser más duras y más masculinas que el hombre con el que trabajaron. Así es como ellos sobreviven, eso no debería ser. 
Ariel Dulitzky,

Universidad de Texas

Volver al índice - English Version

\section{Conferencia: "Empoderamiento y derechos humanos en las minorías étnicas"}

Ariel explicó que todo el sistema internacional de protección humana se basa en la regla de igualitarismo y no discriminación reconocida en el primer artículo sobre la Declaración de los Derechos Humanos. Esto es lo que guía todo el modo en que se interpretan los derechos. Lo que también es importante entender es que la discriminación incluye toda la distinción, exclusión o preferencia basada en ciertos motivos, ya sea nacionalidad, color, ideología política, sexo, orientación sexual o religión, incluso posición económica. Este aspecto puede no solo tener el objetivo de discriminar, sino que puede hacerse en la búsqueda de resultados que puedan favorecer a ciertos grupos de personas. Por ejemplo, una regla neutral que puede dar ventaja a un grupo en específico, como "un examen para un trabajo en español". Esto puede parecer una regla inocente, pero realmente está siendo un factor discriminador contra las personas que no hablan español. Este es un tipo de discriminación que tiene el efecto de diferenciar a las personas.

No habría discriminación cuando no son suficientes legislaciones que soporta eso. Y lo importante en el derecho internacional es que esta regla de igualitarismo no solo le pide al Estado que aplique políticas contra la discriminación, sino que debe aplicar políticas positivas que garanticen una igualdad real en posibilidades y oportunidades. Una vez que hay un análisis hecho desde este punto de vista basado en los derechos humanos, existen otras características importantes para garantizar la libertad de expresión en las minorías, especialmente.

Por un lado, todo el sistema de derechos humanos se creó en torno a la noción del rol del Estado en una paradoja que influye en la forma en que vemos la igualdad. Vemos al Estado como el discriminador, pero al mismo tiempo lo vemos como el defensor de estos derechos. Esto genera mucha tensión y dificultades, especialmente cuando se habla de autoritarismo en gobiernos o dictaduras. Se pudo ver la violencia doméstica que no estaba involucrada en un problema de derechos humanos, pero gradualmente se considera un deber del Estado responder desde una perspectiva de derechos humanos. Ahora el principal debate entre los actores no estatales y los crímenes contra los derechos humanos son las grandes empresas, las transnacionales, los grupos terroristas como Boko Haram que cometen cientos de abusos contra los derechos humanos, pero no son reconocidos como Estado. 
Estas dinámicas han hecho que el significado de los derechos humanos se expanda a través del Estado y no de los actores estatales, además de los medios de comunicación. Al analizar que estos medios privados tienen un enfoque de derechos humanos. Originalmente, cuando se redactó la declaración de los derechos humanos, los derechos humanos se consideran derechos individuales. Algunos a través de grupos humanos. En el caso de los derechos de las minorías, muchos de estos derechos no se ejercen individualmente sino colectivamente.

La libertad de expresión como usted sabe está re conocida en el artículo trece de la Convención Americana como un derecho individual, sin una concepción colectiva. La característica de este derecho es que no puede ser objeto de una censura previa, ya sea directa o indirectamente. La libertad de expresión actúa como una búsqueda para dar y recibir información como ideas, ya sea papel, escrito o de cualquier otra forma, por lo que todos los medios reales (internet o redes sociales) también están cubiertos por estos derechos. Siguiendo varias reglas para regular la libertad y el contenid o o el acceso a las redes sociales. La libertad de expresión es esencial en la producción de otros derechos que también tienen esta doble dimensión, ya sea individual o social. Además, la libertad de expresión está íntimamente relacionada con otros derechos.

Por ejemplo, en mi propia experiencia laboral, trabajo con personas que desaparecen y dar y recibir información es un aspecto esencial de la libertad de expresión para luchar contra las desapariciones forzadas. Libertad de discurso, incluso cuando es un derecho fundamentalen la declaración de los derechos humanos, al igual que el principio de igualitarismo y no discriminación, debe ser un derecho absoluto, por tal imposible de eliminar o disminuir. Si no está limitado por el secretario o la autoridad, sino por una ley de congreso que sigue un objetivo legítimo teniendo en cuenta los derechos de todos, incluso de las minorías. Además, tiene que ser proporcional, por ejemplo, para garantizar los derechos de las minorías en medios de comunicación, por ejemplo 23 de las 24 horas de programación de uno de los medios privados tiene que ser dirigida a minorías. Este no será un objetivo permisible, tiene que ser proporcional.

En la declaración de los derechos humanos, hay cierta definición de lo que se considera una minoría ¿y por qué no hay una definición clara? Debido a que el tipo de minorías que encontramos en diferentes partes del mundo, hablamos de un derecho que tiene que aplicarse y validarse en 192 países de la ONU y la situación de las minorías son muy diferentes. Hay minorías étnicas, nacionales minorías, lingüística, religiosas y ninguno de ellas comparten características. Todo esto genera ciertas dificultades en el momento de definir este concepto. Es por eso porloqueeste concepto se trabaja con criterios objetivos y subjetivos.

Las minorías se definen como un grupo de personas con un número menor que la población mayoritaria. Sin embargo, esta definición ha ido cambiando y ahora se entiende minorías como un número reducido de personas sin posición dominante en la sociedad. Este cambio de concepción de la minoría se da después de la situación de la gente negra en Sudáfrica, allíla minoría blanca era la que tenía el papel dominante en el país y el número de personas mayoritarias estaba subordinado a la política blanca. Entonces, la minoría se ha convertido en este término para definir un grupo de personas que no tienen predominio en el lugar donde viven. $Y$ esto en un país como Ecuador, nos lleva a pensar si grupos indígenas pueden o no pueden ser considerados como minorías. 
Foro,

Participantes: Luis Padilla y Javier Arcentales - Moderadora: Bélgica Calderón

\section{"Retos con la diversidad étnica en el mundo del periodismo"}

Bélgica Calderón: Queremos saber cuáles son los desafíos de la diversidad étnica en el mundo del periodismo. Los desafíos que están por venir, los desafíos que tenemos ahora con las minorías ¿Las minorías étnicas se sienten representadas en los medios tradicionales?

Luis Padilla: La pregunta es si nos sentimos representados en los medios de comunicación y hablando desde el punto de vista proporcional de la población ecuatoriana y las poblaciones afroecuatorianas, somos aproximadamente el 7,5\% de la población total ecuatoriana. Es evidente que en los medios no hay representación, al menos en esa proporción de la cultura afroecuatoriana, o cualquier otra minoría. No existe un enfoque para visualizar estas minorías, pero es visible la exclusión de hasta qué punto se vende la información de estas minorías, o qué tan atractiva es esta información para la audiencia.

Bélgica Calderón: ¿Cómo se sienten representadas estas minorías en los medios tradicionales?

Javier Arcentales: Lo primero que propondré es un cuestionamiento difícil sobre lo que significa minoría. Creo que, en este panel, es importante hablar sobre cuál es el significado de las minorías, porque estos términos dan la idea de un favor, de hacer un favor a un pequeño grupo, por lo que el gran grupo da y aprovecha. Creo que es el momento de hablar de diversas etnias porque creo que el desafío allí es cuestionar a nuestro país como diverso, puede ser étnico, cultural. Creo que es momento de cuestionar este término de la minoría. Debido a que no es un una cosa sobre la mayoría o minoría, se trata de los derechos de cada individuo.

Hablando de representación, no hay acceso en la representación, sino también de lo visual, la forma en que las diversidades de imagen están siendo representadas. Creo que un punto clave en las representaciones de las diversidades es que ello se sigue centrando en el prejuicio. Quiero decir que los medios frecuentemente reproducen el prejuicio de lo que se considera una cultura afroecuatoriana. Entonces, hablar sobre la representación no solo en términos de democracia sino también sobre la imagen de cómo están siendo representados. De cualquier manera, desde el prejuicio o el folclore, o incluso desde un punto de vista turístico de cuán hermoso y diverso es el Ecuador. Así que estos también están queriendo reproducir estereotipos. Esas son imágenes que funcionan para vender, pero que no son reales.

Bélgica Calderón: ¿Deberían los medios producir noticias en idiomas ancestrales, como el kichwa, o incluso mantener la forma en que hablan o expresan?

Javier Arcentales: Creo que sí. Creo que el desafío de la diversidad porque en el momento que hablamos de diversidades, 
no solo hablamos de derechos que son particulares de cada comunidad y cultura, estamos hablando de otros colectivos que tienen sus propios derechos. Al igual que lo que sucede con las personas sordas. También necesitan su propio idioma para comunicarse ¿Cómo responder a las necesidades de todas las diversidades de la comunicación? Creo que uno de esos términos es usar su propio idioma desde un punto de vista muy particular. Ese es el desafío porque no se trata solo del lenguaje como un modismo, sino como una expresión cultural.

Luis Padilla: Como dijo Bélgica sobre la necesidad. Será posible al menos en las redes sociales, como parte de esta construcción intercultural de lo que la información y las ideas crean. Además del idioma, también incluiré el dialecto porque, por ejemplo, en la cultura afroecuatoriana no es necesario tener un idioma como distinción, pero hay dialectos que pueden identificar y diferenciar nuestra cultura. No es el significado de diferenciar como algo malo, sino como el factor que hace que las personas entiendan que hay ciertas formas de expresarlo. Por lo tanto, el desafío también debe ser en las radios comunitarias y canales de televisión y hasta qué punto las personas de esas diversidades pueden usar su propio idioma y dialecto.

Hace algunos meses, el grupo "Pensamiento Afrodescendiente" presentó un diccionario con términos afroecuatorianos que muestra la importancia de apropiarse de este dialecto y dejar de verlo como un folclore, sin hablar de él como una forma importante de expresión y arte, sino como una forma de exotizar nuestra propia cultura.

Bélgica Calderón: Si no me equivoco, hace algunos años ya había noticias hechas en kichwa a las 5 am, esto fue suspendido debido al lenguaje universal en los medios. Después de eso, el lenguaje de señas también se hizo conocido. Cada noticia tenía su propio traductor de signos. Y otra cosa, hablemos del término minorías. Este grupo de personas dice que las noticias de kichwa no se emitieron a las 7 de la tarde cuando todos pudieron verlo. Estos también son un gran desafío para la diversidad en el mundo del periodismo. Ahora, ¿cómo podemos hablar sobre las noticias interculturales sin caer en el folclore?

Luis Padilla: Tenemos que entender que el folclore no es algo malo. Pero al responder a la pregunta, podemos caer en algunos estereotipos. Primero, la importancia es mínimo en la agenda, ¿cuál es la importancia de ese contenido para los patrocinadores o la audiencia? ¿Qué tan rentable es esa noticia? El desafío vuelve a recordar eso y no estigmatizar la cultura y comprender el conocimiento y esa información intercultural. Tenemos que educar a nuestros medios de comunicación y los medios tienen que educarse a sí mismos a través de Internet, libros, a través de la academia. Los medios deben primeroeducarse a sí mismos para educar a la audiencia y no reproducir los estereotipos.

Javier Arcentales: Sí, estoy de acuerdo. Responderá estas preguntas desde la perspectiva del abogado y como alguien que mira televisión todos los días. Lo que realmente me molesta es la falta de comprensión de las personas que generan contenido sobre interculturalidad. Puedes escuchar el "Segmento Intercultural", pero es extraño cómo se habla la interculturalidad allí. Como la mayoría de las veces, este tipo de programas muestran el bello paisaje de nuestro país o hablan sobre la historia y las culturas antiguas, eso se muestra como interculturalidad. Creo que va más allá de eso ya que nuestra institución dice que la interculturalidad es este igualitarismo y el diálogo entre diferentes culturas y que supuestamente pretende un cambio ¿Quién define qué significa interculturalidad? La idea real de la interculturalidad no está funcionando. Los medios reproducen estereotipos con aquella audiencia que tiene contacto con dichos programas. 


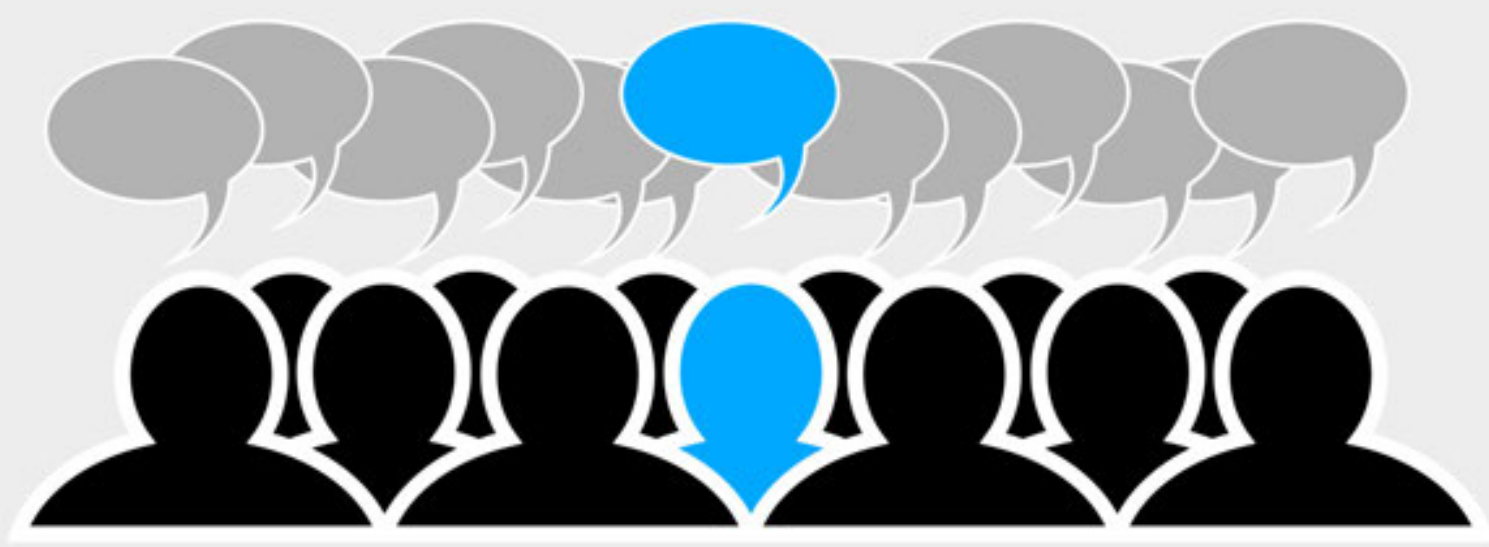

El racismo nos ciega

Es importante trabajar en una sociedad que busca la igualdad escuchando a las personas sin importar de dónde vengan.

Eric Samson: Acabo de recibir una pregunta. Hace un año, uno de mis alumnos hizo una investigación sobre interculturalidad. Le preguntó a la Supercom el significado de la interculturalidad, pero nadie le dio una respuesta. Tal vez uno de los problemas es que no hay un significado exacto de eso.

Javier Arcentales: Sí, y cuando la misma Supercom está dando criterios para sancionar programas que no encuentran suficientemente intercultural, funciona más como una excusa para sancionar. $Y$ ese es uno de los puntos, el problema no solo en las personas que generan contenido en los medios sino también en las personas que crean las políticas públicas para regular esto. No ha habido un proceso para definir este término, se ha convertido en un proceso de alguien que saca una definición de un libro y lo aplica. El proceso debe hacerse a partir de la realidad que la gente está viviendo y así construir la definición.

Eric Samson:¿Quién decide la terminología?
A algunos de mis alumnos no les molesta la palabra "negro", a los demás les molesta y mucha gente se los pregunta a sí mismos. Está claro que hay algunas palabras que son peyorativas, pero ¿cómo se debe hacer ese proceso? ¿Qué palabras son correctas o incorrectas de usar? ¿Hay términos aceptables para todos?

Luis Padilla: Sobre eso, el debate es continuo, incluso entre los afreoecuatorianos. El debate es sime defino como una persona negra o como un afroecuatoriano. El término es solo un constructor y una palabra que reafirma nuestra sociedad de política. ¿Por qué político? Porque está en la constitución y en la historia que acompaña. Ahora, trabajarcon el término negro y todo lo que conlleva a lo largo de la historia y el estigma que la mayoría de la sociedad tiene con él, significa que, si queremos reafirmarnos como 
negros, se necesita un cambio completo en la constitución. Como dije antes, un periodista, un experto en comunicación que proporciona información, expresa conceptos y análisis, debe auto-reconocerse y auto educarse sobre estos términos.

Bélgica Calderón: Creo que es necesario sentarse en una mesa de trabajo y rediseñar lostérminos empleados. Porque, no es posible que algunas autoridades definan lo que significa interculturalidad sin un indígena o un afroecuatoriano sentados en esa mesa. Eso es algo impensable que realmente sucede. Comoelejemplo de laSupercom donde envían su definición intercultural cuando no hubo acuerdo con las sociedades interculturales. Lo mismo con el uso de términos, se trata de sentarse a decidir eso. No puedo ir a estas universidades y hablar de cómo soy la primera mujer negra ecuatoriana que habló en la ONU sin decidir con todos en mi propia cultura que el negro es el mundo con el que queremos definirnos. ¿Ese término dice quiénes somos? El término negro fue con el que la historia nos definió, el término afroecuatoriano aparece en 2011.

Eric Samson: Si bien existe el debate sobre el uso de términos. ¿Cuáles usarían los medios?

Bélgica Calderón: El debate continúa, pero personalmente considero que ese deber es nuestro, no el de los medios. Si los medios ya nos abren sus espacios, tenemos que dar una definición de interculturalidad y cómo queremos ser definidos, nombrados e incluso con qué conceptos queremos trabajar. Además, en los medios cuando se habla del segmento intercultural no es necesario que sea manejado por un indígena 0 un afroecuatoriano. Como ejemplo, en mi caso, me contrataron para trabajar en el segmento intercultural porque no pude estar en las noticias ya que no había noticias para los negros. Por lo tanto, ya que no es ninguna novedad para la gente negra, me dijeron investigar o tomar algo de internet para llenar el espacio intercultural. Pero no, nosotros, los afroecuatorianos podemos generar contenidos nuevos y así estar en el prime time.

Javier Arcentales: En los medios existe un marco normativo sobre derechos que es la Constitución, que define estos términos sobre los afroecuatorianos. Ese es un término que está constitucionalizado y es capaz de usar. Creo que el otro debate va desde las identidades que cada cultura construye. Algunas personas deciden llamarse negras y otras no. Pero en los medios, creo que es necesario verificar este marco y hablar con esos términos.

Bélgica Calderón: Además, creo que depende mucho del contexto en el que se usa el término. Sidecimosnegro como una palabra peyorativa, cambia el significado. Continuando ¿crees que los medios son una herramienta para eliminar el racismo?

Javier Arcentales: Seguramente, la construcción de la opinión pública por parte de los medios es algo real. Los medios trabajan para cambiar los estereotipos, reproducirlose incluso crear otros nuevos. Creo que la interculturalidad es este principio de igualitarismo que busca cambiar las diferencias y las relaciones injustas que ha habido. El llamado de los medios es cómo cambiar y poner esta igualdad en sus contenidos. Porque al reproducir estos estereotipos, el público sigue creyéndolo y reproduciéndolo también. Es un juego entre los medios y el público, como uno que hace estos contenidos que reproducen estereotipos y el otro los acepta.

Luis Padilla: No olvidemos que somos el cuarto poder, entonces definimos y construimos estereotipos y construcciones en la audiencia. Los medios son una herramienta que correctamente utilizados pueden convertirse en herramientas para promover la igualdad y la interculturalidad, porque el término intercultural elimina el racismo. $Y$ hay toneladas de programas realizados que solo crean estereotipos sobre las culturas ricas de 
nuestro Ecuador. Los estereotipos que permanecen en nosotros y luego se reproducen como odio.

Público: ¿Cómo o qué estrategias podrían tomarse para hacer que estos programas interculturales se transmitan en televisión? Porque sabemos que los medios intentan vender, por lo que, si el programa no se vende, no se emitirá. Entonces, ¿qué estrategias, nosotros como comunicadores, podemos utilizar para cambiar estos?

Luis Padilla: Hay algo clave en lo que hablas sobre los intereses económicos. ¿Hasta qué punto la información está siendo vendida por los medios? Es necesario que no porque sea un programa afroecuatoriano o indígena tenga que ser de mala calidad en comparación con los programas de la mayoría. Hoy en día, Internet nos brinda cientos de herramientas que pueden ayudarnos a crear y editar vídeos de gran calidad. Con un vídeo viral simple, podemos comenzar una revolución, así que sobre lo que usted habló acerca de un programa kichwa que no se vende y tiene que transmitirse en una hora inconveniente, entonces eso significa que tenemos que comenzar a poner estos programas en otros medios como Facebook o Instagram.

Público: Sí, pero desde nuestro punto de vista como comunicador. ¿Qué estrategias debemos usar con los medios para transmitir nuestro programa intercultural?

Bélgica Calderón: El entorno que encontramos en los medios es a veces el propietario del canal que decide qué o qué no se emitió. Ahora, es importante que ustedes, como comunicadores, tengan el desafío de diseñar programas de calidad y saber cómo vender esa idea al propietario, el director de noticias, y convencerlos. Porque la mayoría no se trata de los intereses del propietario, sino de los intereses del público. ¿Quién está viendo? ¿Quién está escuchando? Porque si tenemos una sociedad educada, verán mi programa, pero ahora mismo, no tenemos una sociedad educada y prefieren ver los mejores programas que a nosotros, como comunicadores académicos, no nos gustan. $Y$ la gente prefiere esos programas, por lo que nuestro desafío no está en los intereses del propietario o para poder vender un programa en kichwa o con valores afroecuatorianos, lo importante es tener un programa de calidad y educar a la sociedad para consumir lo bueno.

Javier Arcentales: La sociedad ve estos idiomas y dialectos como una obligación, así que solo los medios se colocan en la posición de que solo porque la ley me obliga, lo hago. Y en ese "yo lo hago ", los medios deciden hacer lo mínimo para estar fuera de la vista de la ley y notienen problemas, es poreso que los medios lo ven molesto y es por eso que pone las noticias del kichwa en 5 am, y ese es el mejor ejemplo de lo que hacemos como sociedad. Personalmente creo que esos contenidos no solo deben estar hechos para los kichwa o los afroecuatorianos, sino también para aquellos que no pertenecen a estas culturas y que pueden estar interesados en estos programas. Cómo un programa de buena calidad da la llamada a todos a interesarse por Ecuador y nuestra historia.

Público: Mi pregunta se centra en las organizaciones o el ensamble donde hay personas que representan estas culturas diferentes, pero, sin embargo, estas personas nunca se interesan por lo que está sucediendo en su comunidad o por los problemas que necesitan ser resueltos. No saben nada, pero aún representan a los afroecuatorianos o indígenas. ¿Cómo podemos lidiar con eso?

Bélgica Calderón: En el momento en que hay un afroecuatoriano en la Asamblea, se olvidan por completo de que son afroecuatorianos, y esa es una realidad muy triste. Ese tipo de personas deberían ser las responsables del cambio y nosotros, como ciudadanos, deberíamos dejar de votar a las personas por su aspecto.

\#PerDebate17 


\section{Foro,}

Participantes: Juan Pablo Rojas, Emilio Granja y Santiago Acosta

Moderadora: Karina Marín

Volver al índice - English Version

\section{¿¿Son inclusivos los medios?"}

Karina Marín: ¿Ha habido representación de los grupos marginales gracias a la Ley de Comunicación?

Santiago Acosta: El tema de la Ley de Comunicación es muy complejo. Creo que tiene una muy buena parte que por principios permite llegar a nuevos temas, especialmente interculturales, pero hacerlo realidad en los medios es la parte más difícil. Esto implica cómo se crea reflexión en los medios, ya sea un canal de televisión o radio, para incluir diferentes grupos. Y es un paso que todavía estamos tomando y que seguramente durará mucho tiempo para cambiar a todos los que trabajan en los medios.

Emilio Granja: Es muy complejo incluir a las minorías en los medios porque son todas diferentes. Por ejemplo, con discapacidades, es necesario cambiar el entorno para ellos y adaptarlo y tener un poco de paciencia ya que no todos tienen el mismo ritmo. Es mucho más que incluirlos laboriosamente 0 darles un trabajo debido a su discapacidad, así que estoy de acuerdo con ustedes, ya que creo que todavía hay mucho por hacer y tenemos que seguir dando espacios para seguir creciendo.

Juan Pablo Rojas: Es importante reconocer el contexto, antes de esta ley sólo había una normativa muy ambigua que, básicamente, fue el Consejo Nacional de Telecomunicaciones que controla los contenidos, así que básicamente no había regulador, ya que no había control de contenido. Sin embargo, creo que esta Ley de Comunicación Orgánica vino a establecer algunas reglas en el mundo de la comunicación, pero el asunto allí es que la disposición de la ley que obligaba a la inclusión de ciertos grupos era demasiado difícil. No quiero decir que fueron forzados, pero lo hicieron rápidamente cuando los medios no estaban listos para algo así. Eso me hace compartir los mismos criterios con mis colegas porque en realidad ha sido muy complejo equiparar la Ley de Comunicación, sus disposiciones con los medios.

Efectivamente hay un antes y un después, y por ahora, creo que, desde mi experiencia, hay un gran intento de llegar a esas disposiciones y hay muchas formas en que los medios

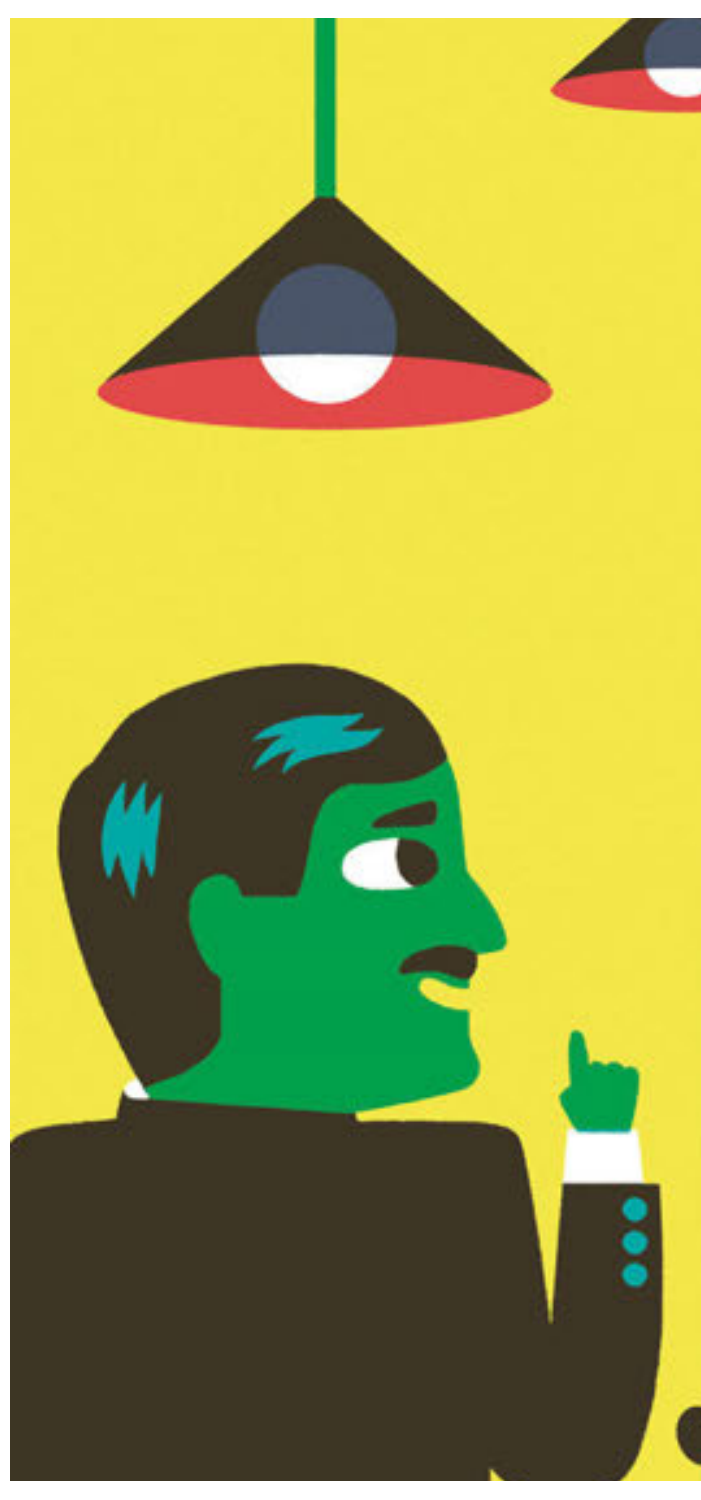




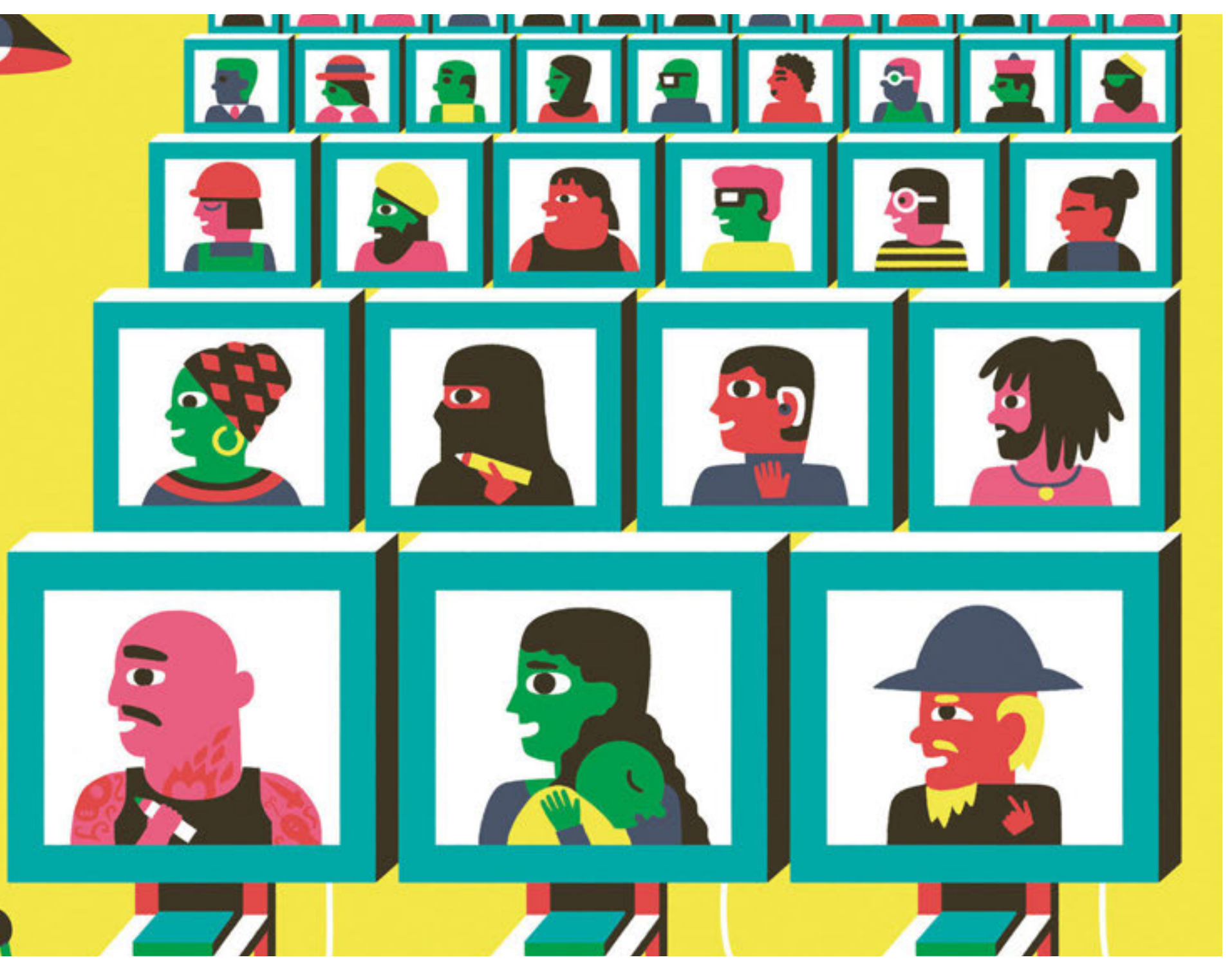


se han vuelto inclusivos, tal vez más adelante podamos hablar de Ecuavisa, experiencia que es muy interesante.

Karina Marín: La inclusión, este concepto ha sido muy cuestionado ya que se considera una minoría forzosa mente incluida en la institución, podemos llamarla media. Y las ideas reales son ese movimiento para ser mutuo, entonces eso ya es una problemática. Hablamos de inclusión, idealizamos y que termina siendo en concepto vacío. Pero el concepto, me importa más en esta pregunta, es la representación. Porque gracias a la Ley de Comunicación hemos podido representar a algún grupo. Creo que las discapacidades siempre han estado representadas, no es que esto haya comenzado ahora, siempre ha estado ahí. Ahora, el problema es ¿cómo ha sido representado? Esa es mi pregunta, entonces tenemos que preguntarnos si la Ley de Comunicación ha cuestionado esta representación de la discapacidad. discusión donde podemos hablar sobre este tema no existe. Y es muy triste cuando quieres invitar a los mejores periodistas a talleres para reflexionar sobre discapacidades 0 interculturalidad, los periodistas simplemente no van, no quieren ir. Tenemos que generar espacios donde los medios, la sociedad, las universidades y las comunidades continuamente hablen de esto.

Emilio Granja: Me gustaría hablar de un ejemplo de tu blog Karina. En un episodio de "Castigo Divino", Jorge Ortiz habló de Lenin Moreno usando términos agresivos. Creo que eso representa a nuestra sociedad, a cómo tratamos a las personas con discapacidades. $Y$ si piensas en este periodista en la posición de poder en la que está y ha sido visto por tanta gente en la televisión, todos pensarían que es correcto tratar a la gente así y eso dice mucho sobre nuestra sociedad. Cuando representamos a personas con discapacidad

\section{Hay trabajos que Ecuavisa realizó en 2014 y 2015 con respecto a poner la autoridad, los grupos vulnerables y los periodistas en la mesa y hablar conjuntamente sobre el tema. \\ permanecemos hasta la imagen positiva y no}

¿De dónde estamos representando la discapacidad? ¿Qué discursos continúan, cuáles son cuestionados? $\mathrm{Y}$ la siguiente pregunta es si los medios son un reflejo de la sociedad para los grupos vulnerables.

Santiago Acosta: No necesariamente, creo que es una idealización muy fuerte decir eso. Cada medio tiene sus propias diferencias, y yo hablaría sobre el ejemplo de Ecuavisa. Hace dos años, hicimos un poco de trabajo para hablar sobre estos temasy fue una experiencia muy positiva en Quito y Guayaquil. Hemos trabajado con todos, desde de la producción. Con la Defensoría del Pueblo hemos hecho en los últimos 4 años una gran cantidad de talleres con más de 800 periodistas de todo el país hablando de estos temas, y utilizamos el ejemplo Ecuavisa.

Los medios a veces tienen situaciones económicas muy difíciles. El espacio de hablamos de más problemas que puedan tener, a pesar de que las personas con discapacidades tienen problemas como cualquier otra persona. No creo que eso sea suficiente cuando se habla de discapacidades.

Juan Pablo Rojas: Creo que responder esa pregunta positivamente es presentar algunos criterios que pueden no ser lo que estamos buscando porque existe una gran variedad de medios y eso puede no significar que sean el reflejo de su público. En realidad, el trabajo que Ecuavisa ha hecho en 2014 y 2015 respecto a poner sobre la mesa la autoridad, los grupos vulnerables y los periodistas y de manera conjunta hablar acerca de este tema. Teníamos al dueño del canal sentado, junto al productor, los editores, activistas e incluso niños en muchas rondas de talleres que prácticamente duraron dos años ¿Y por qué? 
Porque necesitábamos recoger información y educar a las personas.

Invito a todos a acceder a ese documento que publicamos después de este trabajo, es un documento público $y$, al principio, invitamos a todos los medios a ser parte de esto. Recuerdo claramente que el canal estatal estaba allí, pero no terminó el trabajo. Finalmente, después de haber hecho este documento lo compartimos con más canales e incluso algunas organizaciones. Por lo tanto, nuestra referencia es la Ley de Comunicación, pero nuestra fundación se ha hecho por nosotros mismos, la construcción de diálogos, en el foro con la participación ciudadana, que nos dejó con pensamientos y experiencias enriquecedoras, como qué decir, lo que no quiere decir, cómo representar o no hacerlo.

Karina Marín: Acabo de recordar ese texto que escribí sobre "Castigo Divino" y quiero decir algo que en ese caso específicamente mencioné. En ese momento, dos periodistas emblemáticos en Ecuador, Janet Hinostrosa y Jorge Ortiz, usaron términos agresivos para disminuir al actual presidente. Lo que valía la pena notar era la paradoja y fue que diez años después de anunciar que este país vive la inclusión, nuestro propio candidato presidencial fue excluido del lenguaje y eso solo puede ser la demostración de que las políticas públicas ambiguas no van por encima de lo superficial y creo que, en parte, eso es lo que los medios representan en el resto de la sociedad.

¿Los medios son clave para transmitir un mensaje que puede cambiar la percepción que la sociedad tiene sobre los grupos marginales?

Santiago Acosta: Obviamente somos los multiplicadores de la opinión. Para nosotros es vital qué medios usamos siempre, un ejemplo muy práctico, si eres madre y escuchas algunas noticias que compartes con tu familia. Si tienes una tienda, hablarías con tus clientes. Si eres sacerdote, hablarás con la cantidad de personas que van a la iglesia. Un medio de comunicación puede llegar a miles.
Tuvimos un caso en Puyo, cómo un periodista habló de noticias falsas en Internet, tomó las noticias y publicó y dio como resultado que en Puyo todo el mundo lo cree como verdad. Los medios tienen un papel clave en esto y en la persona que trabaja en él, las personas que generan esta información y programas son las personas que necesitan la capacitación más continua. El ejemplo que utilizó de "Castigo Divino" y el usado de terminología. Un periodista y guionista debe saber cómo usar las palabras respetando los derechos.

Emilio Granja: Los medios son importantes en el momento de transmitir un mensaje, como hablar en terminología y es común escuchar la palabra "habilidades especiales" y no es cierto porque las personas con habilidades especiales son los superhéroes y no me considero un Batman que resolvería crímenes mañana, así que no creo que sean términos correctos. Ni siquiera diferentes habilidades. Esa persona es alguien que hace lo mismo que usted de una manera diferente y no hay nada diferente con alguien que tiene discapacidad.

Considero que mucha gente está equivocada en el momento de transmitir elmensaje o tratar de etiquetar a alguien para no lastimarlo. De esa manera victimizamos a la persona que los medios quieren evitar. Pero sí, creo que los medios son la clave para transmitir mensajes. Tenemos que incluir más a las personas con discapacidades y hacer más contenido para ayudarlos.

Juan Pablo Rojas: Los medios educan, por supuesto, pero también informan y entretienen. ¿Cómo hacerlo? Es la información básica que tenemos que tener presente en el momento para elaborar un informe o transmitir un contenido que educará a la audiencia y seguramente se entretendrá, porque para entretenerse como tal, cualquiera puede hacerlo. Es por eso que tenemos parámetros y códigos para hacerlo. Tenemos que considerar eso como la 
dinámica de los medios, porque existen, y se dedican a hacerlo durante 24 horas. Hay otros medios que tienen contenido para entretener, información y lo importante es que la audiencia elige qué mirar. Lo importante es que un Estado no te dice qué mirar. En cualquier caso, creo que los medios tienen un papel muy importante en la función, ya sean tradicionales o digitales.

Karina Marín: En primer lugar, la terminología, uno escucha hablando a ciertos periodistas y dan vueltas para decir lo obvio, como tratar de ser políticamente correcto, y esto puede acabar en muy malas situaciones. No sé si saben que el año pasado fueron 10 años de la declaración de la ONU por los derechos de las personas con discapacidad, Ecuador firmó esa declaración en 2008, así que el próximo año, pasarán 10 años desde que Ecuador se comprometió a esta declaración.

Toda la declaración queda fuera de algunos principios básicos de la discapacidad, no tiene nada que ver con el ser humano en sí. La discapacidad es un concepto que habla de la circunstancia de una persona en particular, ya sea física, biológica, mental, sensible o hablado, cuando se la ve en una sociedad que no permite el acceso al igualitarismo de las condiciones. Eso es una discapacidad. Entonces, yo, que soy madre de un niño con una discapacidad, digo que también tengo una discapacidad, porque la sociedad no me permite tener las mismas condiciones con mi hijo en esos lugares. $Y$ usted (Emilio) es una persona con discapacidad en la medida que pueda siempre encontrará obstáculos para acceder a las condiciones de igualitarismo.

Esto es algo muy evidente que al menos los medios ignoran que es un triunfo una pelea que comenzó en los años 60 en Estados Unidos y Europa, específicamente en Inglaterra, que promovió elmodelo social de discapacidades. Y lo que este modelo hace es reaccionar contra el modelo médico de discapacidad, quiero decir que no somos sujetos de la enfermedad de piedad. Somos sujetos de derechos y esa visión, la discusión tiene que cambiar. Aparentemente, no sabemos nada de esta revolución que comenzó en los años 60 en este mundo con el lema "nada sobre nosotros, sin nosotros".

Los invito a que lo sepan, porque creo que cualquier comunicador puede hacer su trabajo sin conocer la declaración de los derechos humanos de las personas con discapacidad, así como la declaración de derechos LGBTI, etc. Es muy importante porque ese es el centro de importantes debates en torno a estos temas. ¿Alguno de ustedes quisiera hablar sobreesto?

Santiago Acosta: El tema de la discapacidad, creo, es una buena forma de hablar sobre los derechos humanos. Hay una cosa que siempre hablamos con cualquier persona que recibe capacitación o educación sobre derechos en todo el país. Cuando te pones los lentes de los derechos humanos, empiezas a ver la palabra de una manera diferente. Comienzas a ver los contenidos de los medios de una manera diferente. Recordaré una reunión con la gente de Vivos antes de que dejara de transmitirse. Uno de los guionistas nos dijo que tiene muchos amigos gays y le preguntamos por qué los está estereotipando. Fue una reunión muy larga, de aproximadamente 6 horas. $Y$ al final, tuvimos el problema de que no habían tenido la oportunidad de usar estos lentes de los derechos humanos, que es una de las cosas vitales para poder entender esto.

Recordamos algunas ocasiones en las que las personas comienzan a ver cosas nuevas y pueden comprender lo que sucede en los medios. Esto funciona para periodistas, productores, músicos, abogados y esto cambia la vida. Es indispensable.

Emilio Granja: Creo que los medios han fallado en cómo mostrar estos derechos cuando representan a una persona con discapacidad porque, como ya dije, seguimos siendo la imagen de la compasión. No he visto lo difícil que es llevar mi carné aquí, lo difícil 
que es ir al médico o esperar que el maestro lo coloque en una calificación más alta o más baja. Incluso, cómo Aneta no tiene automóvil para personas con discapacidades para que aprendan a conducir y no veo periodistas hablando de esto. Entonces, sí, creo que necesitamos espacios, pero también necesitamos más. Por ejemplo, en inclusión laboral. La mayoría de las empresas le dan el trabajo a una persona con discapacidad porque tienen ese espacio, no porque el CV lo haya impresionado. Creo que los medios han fallado y siguen fracasando para explicar esa parte de la discapacidad.

Juan Pablo Rojas: Romper estructuras es muy complicado, pero no imposible. Hemos realizado talleres y conferencias, pero no ha permanecido allí. Tenemos una relación muy estrecha entre los CONADIS que nos han enseñado sobre la terminología, qué decir o no. $Y$ tengo que decir que en esa práctica la gente estaba empezando a conocer sobre esto, así que eso nos preocupó mucho porque básicamente son ellos quienes comparten contenido, pero sinfiltro ni conocimiento. Nos damos cuenta de que cometemos grandes errores. Hemos tenido muchos talleres de CONADIS en el canal porque lo consideramos importante, porque creemos que Ecuavisa tiene una responsabilidad social muy importante con su público.

Tenemos una ley que verifica todo lo que hacemos, pero no tenemos la necesidad de cambiar las cosas. Si ahora miras a Ecuavisa, verás una programación muy responsable, más inclusiva y visualizando cosas que antes no teníamos y algunos filtros. Todo nuestro contenido antes de ser emitido es aprobado por una jurisdicción.

Público: Quiero preguntarle qué conclusiones tiene sobre el trabajo con el canaly los talleres dentro de su equipo de trabajo.

Juan Pablo Rojas: Dos cosas, desaprender y luego darse cuenta de que las personas equivocadas sobre la comunicación estaban sucediendo, fue una de las conclusiones más importantes para nosotros y para eso hicimos todo lo posible para este taller y luego recibimos los comentarios internos que teníamos. Y no se ha detenido desde allí, seguimos aprendiendo. Esa experiencia nos lleva a tener una programación más responsable y a ser más humanos.

Karina Marín: Esta tendencia a hablar como el superhéroe y hacer cosas admirables y hablar sobre el pobre que vive en las peores situaciones. También existe el lugar de lo sobrehumano o infrahumano para las personas con discapacidad, pero nunca los dejamos en el medio. Dentro de los temas, los activistas hemos estado hablando, es el derecho para la asistencia sexual para personas con discapacidades, y aquí las personas mueren con eso, es un tema tabú. Sin embargo, es el momento de hablar de ello porque si no seguimos mirando a las personas con discapacidades, como los ángeles y los ángeles, son asexuales, y eso es incorrecto

Público: Dentro de lo que los medios públicos trabajan en comunicación inclusiva. Santiago habló sobre la comunicación con los derechos. Me gustaría saber, por la propia experiencia de Santiago, cuáles son las cosas negativas y cómo logras que las personas vean las cosas no como tabú sino debate, ¿cómo se llega a esa transición?

Santiago Acosta: Reflexionando sobre la comunicación con un enfoque de derechos, no es una prioridad en el presupuesto. No de la institución, pero cuando puede hacer un gran acercamiento en interés nacional, no puede, económicamente. Mi experiencia durante estos años es que ha creado algunas otras alternativas. Estos temas comienzan con el activismo y el esfuerzo realizado por las autoridades de los gobiernos, la sociedad civil o las universidades. Hablar sobre esto en las universidades es vital porque el profesional que sería en los próximos 10 o 20 años, el contenido que sus hijos consumirían lo haría usted. 
Existe la posibilidad de una ruptura histórica de Facebook y Twitter que apareció hace 10 años, este desarrollo de nuevos medios puede mejorar nuestra sociedad con una nueva ola de pensamiento sobre los derechos, no solo sobre las discapacidades, sino también sobre las mujeres, las personas mayores y las comunidades LGBT. Son grupos de reflexión que van alrededor de estos nuevos medios de comunicación y puedeayudarnos a desarrollar una nueva sociedad y si no tomamos ventaja de estos años, que incluso podría empeorar.

Emilio Granja: Parte de esto también es importante para resaltar el trabajo de los periodistas con discapacidad. Está el caso de un periodista que tiene una discapacidad visual que durante doce años ha trabajado vendiendo caramelos en los autobuses y con la ley laboralencontró un trabajo en los medios estatales. Entonces, hay cosas positivas que comenzarán a desarrollarse cada vez más en todos los medios. Y eso es importante porque no soy yo quien salga a buscar trabajo, creo que habrá cada vez más personas con discapacidad que querrán tener un trabajo, no solo en periodismo, sino en otras carreras. Además, es parte de la inclusión porque todavía pensamos que las personas con discapacidad no pueden hacer el trabajo de un periodista, pero podemos, no hay pruebas de que no se pueda hacer. Es por eso que creo que es necesario tener una cara visible ya que un presentador de televisión con discapacidad ayudaría a alentar a otras personas con discapacidad a hacer lo mismo.

Público: Tuve la oportunidad de trabajar con María en El Comercio, que es una periodista con discapacidad y, en una charla, nos dijo que no quiere que la gente la compadezca, que es una buena periodista, sin embargo, conocí a otras personas. Esto habla de la falta de oportunidades y de no tener una justicia física. Para míes muy complicado hablar de este tema porque depende de cada persona. Entonces, te pregunto, ¿depende de cada persona o es un tema estandarizado? Eso primero, y ¿cómo hablar y tratar este tema con los propios involucrados?

Karina Marín: ¿Te refieres más a la terminología? Es interesante porque en este momento estoy en un debate personal sobre este tema, porque durante un tiempo adopté la terminología utilizada en España que habla de personas con diversidad funcional o personas de la función de diversidad porque eso muestra que todos trabajamos en diversas formas. Algunos ven, otros no, algunos se comunican de otra manera. Pero últimamente con algunas lecturas que he estado haciendo, empecé a cuestionar si esta terminología no es como que yo diga que eres diversa, distinta. $Y$ volvemos de un mundo de poder para disminuir a alguien. Entonces, el tema diverso comienza a rebelarse en mi cabeza y, a veces, prefiero usar, incluso de forma política, las discapacidades. ¿Por qué? Porque cuando dices que una persona tiene una habilidad desde el comienzo de su vida, dices que es capaz. ¿Y una persona con discapacidad los llamó incapaces? No ¿qué sería lo contrario a las personas con discapacidad? Y si eres una persona capaz, significa que alguien te califica para eso.

Entonces, cuando estoy discapacitado, alguien más está clasificando. Una sociedad que no me da suficientes oportunidades para la igualdad. Esta discusión, continuaremos teniéndola, pero lo importante es discutir y crear espacios para hablar de estas cosas, necesitamos el debate, necesitamos la discusión. Necesitamos oírlos decirnos cómo les gustaría que los llamen y que se expliquen a sí mismos. Es a ellos a quienes debemos escuchar.

Santiago Acosta: La virtud que tiene el lenguaje es que continúa cambiando a través del tiempo. El activismo desde los años 60 hasta ahora, nos ha permitido evolucionar en una serie de terminologías y palabras valiosas para nosotros. Estas oportunidades que nos brinda la historia, al menos desde el 2000 en Ecuador, han permitido la búsqueda de nuevas 
palabras y significados para las terminologías que definen a los diferentes grupos de personas. Usted mencionó el caso de los afroecuatorianos. En la oficina trabajamos con un afroecuatoriano y es un placer trabajar con ella, como un orgullo para la oficina. Hacer que este tema sea atractivo para las noticias, es prácticamente imposible. Recuerdo que el primer año que celebramos esto fue en 2012 e hicimos una conferencia de prensa en la que asistieron dos medios.

El lenguaje tiene que ir junto con las acciones y acciones a lo largo de las reflexiones. Es por eso que es necesario que en el momento en que trabajamos con los medios 0 las universidades que preparan a los periodistas del futuro, sepan cuán importantes son estas cosas. En 5 años tal vez, podríamos ver a estos nuevos periodistas promoviendo noticias inclusivas. Esos son algunos temas. Usaría un ejemplo que teníamos con un colectivo con el que trabajamos. La gente bajita, si tenemos una asociación, uno de ellos nos dijo que quieren poder subir al autobús. Se sigue hablando de esto en el gobierno o las autoridades, pero nadie se ha atrevido a dar una solución como una política pública para los autobuses tengan un extra de paso, o buscar nueva normativa.

El lenguaje, la acción y la reflexión deben tomarse de la mano. Si solo buscamos el idioma, las cosas no funcionarán. El papel multiplicador que tienen los medios es colgar una reflexión masiva para las personas. Un blog, una página de Facebook tiene miles de seguidores, ¿podríamos tener una página hablando de estos temas con la misma cantidad de seguidores? Ese es un desafío comunicacional. Cómo llevamos estos temas a la comunicación masiva.

Público:Solo quería preguntar sobre la parodia, porque el entretenimiento también es una parte importante de los medios. Mi pregunta es, ¿qué estándar hay para hacer sátira o parodia sobre estos temas? ¿Qué está bien, qué está mal?

Karina Marín: Una vez escribí un artículo en mi blog sobre una broma hecha por el ex presidente Correa porque refirió al jugador del equipo de fútbol Barcelona como discapacitado. Entonces, hablé sobre este uso del humor, un humor consentido por nuestro presidente actual. Y yo estaba esperando que Moreno reaccionara, y él sólo se rió. Entonces, todo lo que puedo decir sobre esto es que la sátira y la parodia en el mundo en que vivimos tienen sentido si tienen un fuerte contenido político y si el propósito de utilizar el sarcasmo es provocar reflexiones incluso violentas, incluso agresivas en la sociedad. $\mathrm{Si}$ se trata de disminuir a alguien, no funciona.

Emilio Granja: Creo que el problema es la sociedad. Porque, por ejemplo, si vas a un patio de comidas $y$ ves a una persona con discapacidad para caminar y las mesas que están más cerca de donde compras la comida están siendo utilizadas y nadie tiene la intención de ponerse de piey dar el espacio. No puedes ser consciente de esa manera, la sociedad no lo hace. $Y$ ya hablé sobre esto al decir que los medios han fallado en la búsqueda y decir que hay más problemas para las personas con discapacidades. De eso no hablamos porque, como dice Karina, no podemos ser políticamente correctos. Además, las noticias son un $90 \%$ de malas noticias y los medios prefieren tener lo que queda para dar un mensaje positivo a las personas con discapacidad. Y espero que en el futuro haya espacios especializados en este tema porque no creo que los medios tradicionales lo supongan.

Eric Samson: $Y$ espero que esos espacios sean construidos por personas como tú. Esperamos que la página web de su tesis pueda seguir trabajando con Ecuavisa y que todos los docentes estén preocupados de que, a nivel laboral, las personas no permitan que esto suceda. Se graduará en algunos meses, habiendo tomado los mismos cursos que sus colegas, haciendo el mismo trabajo y con suerte encontrará un trabajo tan rápido como todos los demás. Lo mereces. \#PerDebate17 


\section{Día 03}

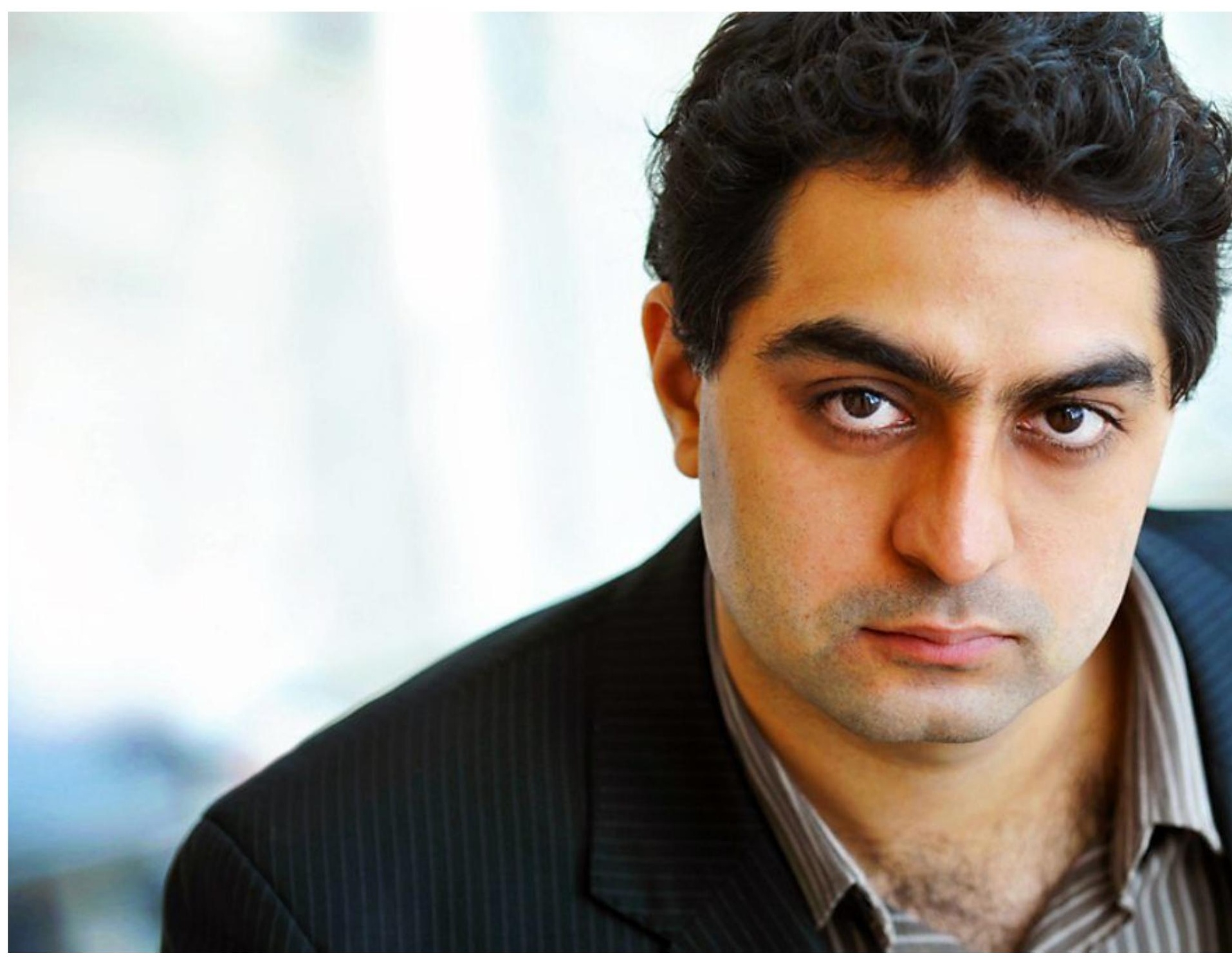




\section{Conferencia Magistral: "De las redes sociales a las noticias"}

Mukul Devichand nos contó dos historias y ambas historias de nuevas unidades que ha creado en la BBC. Cada historia simboliza diferentes historias de cómo el periodismo responde a uno de los mayores desafíos de nuestro tiempo, que es el dominio de las redes sociales. Entonces, primero preguntó quién en la audiencia recibe las noticias no del periódico, sino de las redes sociales. En todo el mundo, la estadística es que muchos países, sus proporciones de adultos que reciben sus noticias a través de Facebook ahora son $50 \%$. Él nos mostró una rana y un emoji.

¿Cree que los editores de los periódicos piensan que es un lugar liviano y no les dan los recursos suficientes para cubrirlo? Los editores tradicionales descartaron la

\section{La noche de las elecciones, Francia tuvo un apagón inmediato en los medios y este fue el momento en que comenzaron las filtraciones de Macron.}

cantidad de periodismo realmente de calidad que pueden hacer en las redes sociales. Él comenzó con la rana. La rana simboliza cómo informa BBC Trending. Mostró una imagen de Emmanuel Macron, presidente de Francia, ganó contra su competidor y fue una carrera muy cerrada debido a las redes sociales. Un hashtag marcaba tendencia con el nombre\#MacronLeaks, que era una cantidad de filtraciones de su correo. No había nada realmente malo en estas filtraciones, pero tenía una tendencia como loca, parecía enojado y malo, y no lo hacía bien. Los editores luchan por informar esto por muchas razones.

La noche de las elecciones, Francia tuvo un apagón inmediato en los medios y este fue precisamente el 
momento en que las filtraciones de Macron comenzaron. Su equipo de periodistas investigó cómo comenzó. Porque eso es lo que hacen, ellos investigan internet. Entonces, descubrieron que esas filtraciones comenzaron a las 7 p.m., realmente no saben quién las puso allí, algunos expertos en seguridad culparon a los hackers relacionados con el Kremlin, otros pensaron que era un lobo solitario. Pero la rana aparece en una pregunta crucial. ¿Cuálesla forma en que se difundieron estas noticias? Su periodista colgó en Internet y descubrió que en una unidad había grupos de extrema derecha que se identificaban en los cuatro canales. Estos tipos no estaban en Francia, sino en los EE. UU., Pero difundieron estas filtraciones. Y puedes decirlo a causa de la rana. Usan la rana como su avatar en las redes sociales. Pepe es una rana muy linda, pero ahora se ha convertido en un símbolo del fascismo global. El hashtag en sí comenzó a las 8 p.m. por otra persona que no estaba en Francia. También se necesita decir que Wikileaks ayudó a amplificar esta tendencia en línea. Entonces, el punto que Devichand intenta hacer aquí es que cada hashtag, cada vídeo en YouTube, en Facebook representa y agenda. Si eres un buen periodista, siempre estás buscando agendas. Las agendas de las redes sociales podrían ser buenas, malas o no te gustarían. El punto es que los investigan adecuadamente, toda la fuerza del periodismo de la BBC, así que este fue por la extrema derecha en Estados Unidos y esto es lo que logran. Al trabajar juntos de esta manera coordinada, los hackers y la derecha estadounidense logran romper el apagón inmediato en Francia.

Macron Leaks tenía una tendencia mundial y en Francia, y los periódicos, estaciones de radio y televisión franceses tuvieron que informar de alguna manera. La moraleja de la historia para los periodistas. Las redes sociales son un lugar que debemos entender, tenemos que informar con toda la fuerza de nuestro periodismo y, cuando lo hacemos, las redes sociales mismas nos recompensan al hacernos llegar clics. Esa es la historia de lo que es BBC Trending.
Nos mostró otro ejemplo de cómo ayudan al público a entender los memes. Entonces, la forma en que contamos las historias también es diferente. Cuando informas en las redes sociales, no puedes hacerlo como si fuera la noticia de la noche. Sus videos reflejan un nuevo tono, no son como los informes normales de la BBC, son para la audiencia en línea. Todo se trata de tono, si pasas suficiente tiempo en las redes sociales puedes decir que la manera de contar la historia y el interés son diferentes. Deben ser más profundos o más ricos o significativos desde el punto de vista editorial.

Las redes sociales son interesantes porque nos muestran cuánto valoran las personas la emoción como punto de partida para contar historias. Entonces, nos contó la segunda historia que trata sobre una unidad que él creó llamada BBC Hacks. Existe una fuerte evidencia de que estamos recibiendo emociones equivocadas en internet. Habló sobre la investigación de Betsi Grabe, quien dijo que las noticias negativas desaniman a las mujeres. La investigación muestra que la BBC es vista como una emisora muy negativa por el público mundial y especialmente en nuestras audiencias globales en los países en desarrollo. La gente piensa que la $\mathrm{BBC}$ tiene que ver con los problemas y nunca con las soluciones. Así que es por eso que crearon BBC World Hacks. Tú haces vídeos cortos y detallas historias de radio de media hora. Cubren todo sobre el desperdicio de alimentos, cómo hablar con los niños sobre sexo, incluso aplicaciones que pueden ayudar a las personas ciegas a ver.

El punto aquí es que no se trata de historias superficiales o porno de inspiración, creo que es una historia periodística significativa, el proyecto se llama Soluciones enfocadas en el periodismo. Este tipo de periodismo va de la mano con el periodismo de investigación diciéndole a la gente lo que otras personas han encontrado como una solución y 


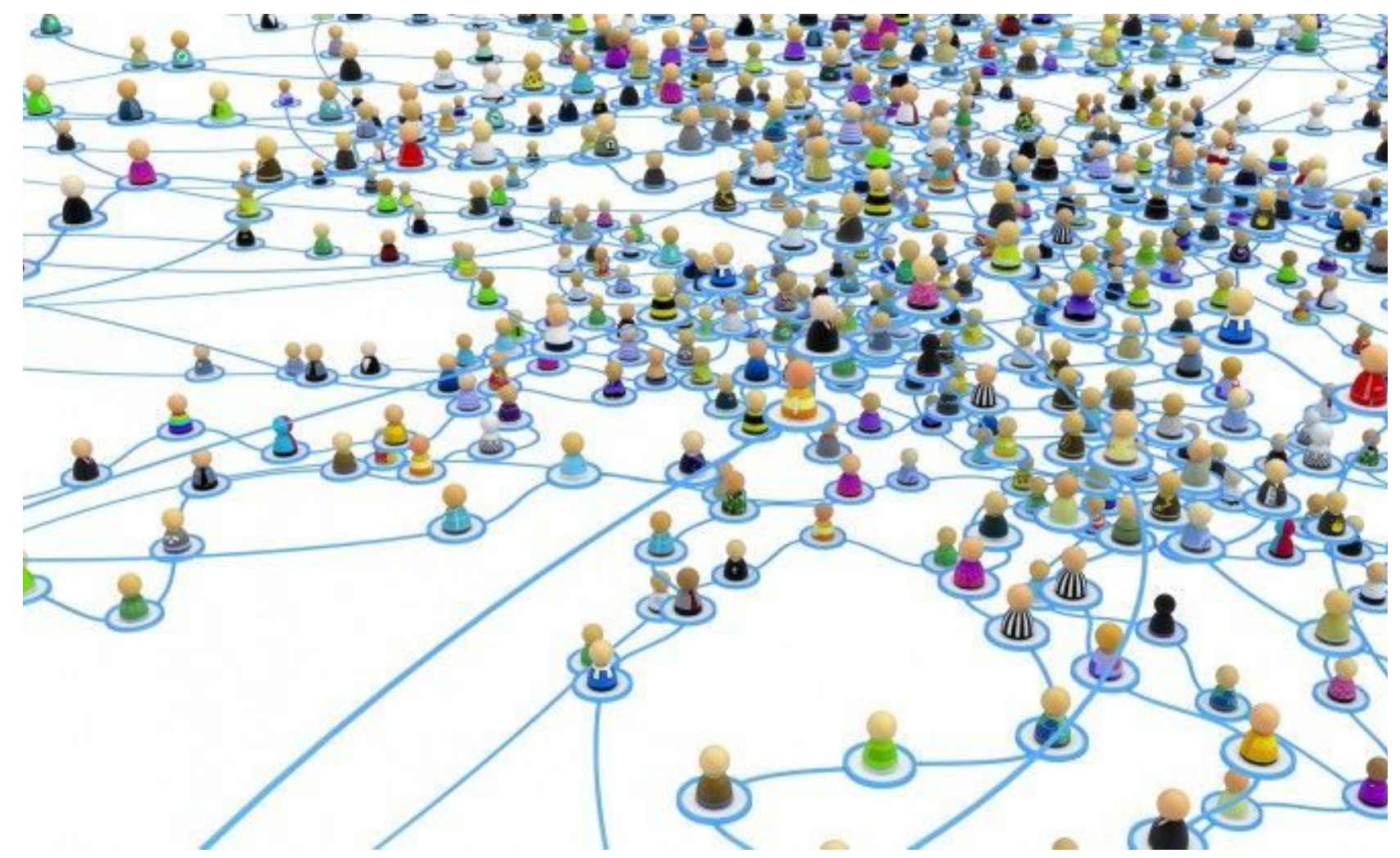

La audiencia crece

Es esencial considerar las redes sociales como las nuevas fuentes de información, siempre considerando el análisis de las fuentes y su redistribución ética.

preguntando si esta solución funciona y el periodismo va más allá. Realmente quieren saber que alguien está haciendo algo bueno, pero ¿realmente va a funcionar? Entonces, hacen videos y también una estación de radio como podcasts donde se escribe la historia. Mukul Devichand dice que es fácil probar que a la gente les gusta más gracias a las estadísticas, el número de me gusta, visitas y participaciones. Él dice que publican dos videos cada semana y tienen un promedio de 5 a 10 millones de "me gusta". La gente realmente quiere este tipo de periodismo, especialmente en las redes sociales y Facebook.

Ahí hay algo importante en estas historias, cuánto cuenta la historia de esta persona de memoria porque eso va muy bien, pero elimina el análisis y la investigación de la solución. También se dieron cuenta de la importancia de contar una historia, incluso si no hay tanta evidencia como un periodismo de ideas. Entonces, crearon este hilo llamado Think Again.

Mukul Devichand cree que es que no debemos temer a las redes sociales. Como periodista, es útil recordar cuáles son los principios de nuestro trabajo y luego adaptarnos a los medios lo mejor que podemos hacer. No puede ser un extra en las redes sociales, ya que estas se tratan de lo algoritmos que generan los usuarios. Son muy difíciles para los medios de comunicación porque les quitan el control, pero para empezar debemos comprenderlos y adelantarnos. Entonces ¿qué sigue? La inteligencia artificial comienza a reemplazar el algoritmo. Por lo tanto, necesitamos encontrar una manera de atacar eso también.

\#PerDebate17 
Nelly Valbuena,

Radio digital "Mujeres Contando" (Colombia)

Volver al índice - English Version

\section{Conferencia"Hablar con / sobre las mujeres: una necesidad urgente"}

Hay muchas iniciativas de mujeres que intentan desarrollar en medios, ya sean tradicionales o digitalizados. Iba a hablar sobre una iniciativa nacida en la radio. Comenzó como un programa en NCR, en una alianza de responsabilidad social de los medios. Eso tiene un montón de responsabilidad por parte de los medios, quiero decir que nos hacen creer que nos están dando un espacio cuando solo lo hacen como parte de sus responsabilidades, al menos en Colombia, aclaró Nelly.

Así es como comenzó el propósito de "Mujeres Contando" bajo la dinámica que NCR les permitió. Luego, dicen que se convirtió en un espacio de diálogo muy importante, especialmente cuando se habla de género y derechos de las mujeres a lo largo del conflicto armado en Colombia. Este programa comenzó en un medio estatal, pero el presidente Uribe, en su primer mandato, cerró la radio. Entonces, se quedaron sin espacio, es decir, cuando decidieron ir a NCR, pero luego se dieron cuenta

\section{...Este espacio está hecho por hombres y mujeres ensibilizados y comprometidos con los derechos de las mujeres y la erradicación de la violencia.}

rápidamente de que tenían una audiencia muy buena, los programas duraron una hora a partir de las 5 a. M. Pero los domingos no se escuchó a nadie. y la pregunta del público siempre fue, si lo van a hacer nuevamente en otro horario. Fue entonces cuando decidieron que era hora de tener un espacio diferente y entonces, comenzaron una radio digital. Al principio, comenzaron con un programa una vez a la semana, pero finalmente ahora tienen una programación de 24 horas y una página en línea dedicada a los derechos de género y mujeres, los problemas y la discusión.

No es un espacio solo hecho por mis mujeres porque para ellas en la fundación es un requisito incluir a los hombres en los temas de derechos de las mujeres y prevención de la violencia contra las mujeres. Este espacio es realizado por hombres y mujeres, hombres sensibilizados y comprometidos con los derechos de las mujeres y la erradicación de la violencia contra las mujeres. Hombres que contribuyen mucho si esta lucha por el igualitarismo entre hombres y mujeres.

Solo como un tema de iniciativa, Nelly es la directora, pero no es algo que permanezca para siempre, siempre están tratando de rotar y poner a diferentes mujeres y hombres a cargo. Cuando se solicita financiación internacional, es necesario tener a una mujer a cargo, porque asíl lo piden, de modo que, si tienen un hombre a cargo, tienen que cambiar. 
.Es más, una oportunidad de financiación que una condición. Las fundaciones y la radio intentan tener una relación más horizontal.

Nelly, subrayó, que para ellos era muy importante darle un marco teórico a este proyecto, por lo que no solo sería un ejercicio de activismo, sino que también realizarían periodismo, activismo y proyecto social para mejorar la vida de las mujeres, es cuando se dan cuenta que ellos necesitan teoría. Se fijaron hacer algunas investigaciones sobre el significado de la utilización de los órganos, especialmente el cuerpo femenino. Cuando hablamos de cuerpos femeninos no solo nos referimos al cuerpo de las mujeres heterosexuales, sino también a estas nuevas formas de intervención del cuerpo para desarrollar una orientación sexual que se construye sobre las historias que escuchamos y los medios de comunicación y son muy difíciles de entender el cuerpo de estas otras mujeres, ya que también tienen problemas para ser reconocidas y aceptadas en el movimiento feminista. Es por eso que trabajamos bajo el enfoque de género que implica reconocer la violencia contra la mujer producida por la construcción de imaginarios y la perpetuación de los roles de género en la sociedad. Eso significa reconocer otras formas de asumir femenino. Trabajan bajo algunos conceptos de Foucault, Judith Butler de los cuerpos de las mujeres.

A partir de ahí, se han realizado algunas investigaciones que les permiten comprender y reconocer la importancia de los medios que hablan sobre los problemas de las mujeres bajo un enfoque de género. Lo primero que vimos, es que hay algunos estereotipos que han hecho que la figura femenina esté condicionada por el mercado. Los cuerpos de las mujeres son cuerpos que el mercado consume para su propio beneficio, son vendidos y modificados por los medios y las necesidades del mercado, son consumidos y desechados. Exactamente como lo que está sucediendo con la vida de las mujeres. Han descubierto que los medios determinan un concepto de belleza en sus cuerpos.
El periodismo ha utilizado el cuerpo de la mujer como objeto sexualizado para atraer más audiencia. Este tipo de estereotipos son los que normalizan la violencia contra las mujeres. 0 bien nosotros, las mujeres, somos sexistas o bien somos vistos como la persona hogareña. El que se queda en la vida privada, en la casa, el que hace las tareas. Han descubierto que las mujeres no son una fuente de periodismo, incluso si hay mujeres más preparadas para algunos temas, los hombres siempre son elegidos como una fuente más confiable. Otra cosa que encontraron fue cómo las niñas pequeñas están representadas en los medios. Las niñas que en realidad están representadas como mujeres, que usan tacones altos y vestidos, eso es lo que las niñas crecen mirando. Además, no hay investigaciones o informes sobre noticias de mujeres, pueden ser sobre violencia o éxito. Las mujeres no son un contenido común visto en los periodismos. No solo se excluye a las mujeres sino también a otros géneros $y$ orientaciones sexuales, de quienes nunca se habla en los medios. Otra forma de representar la violencia contra las mujeres es justificar el hostigamiento y criticarlas, como motivo de ser víctima. ¿Cómo hablar de la violencia en los medios de comunicación con un enfoque de género?

1. Hable desde un punto de vista humano.

2. Incluya mujeres, homosexuales, bisexuales, trans e intersex en sus fuentes.

3. Infórmese para informar.

4. Verifique la información que el caso y la fuente le brindan.

5. Interprete las nuevas realidades sexuales mirando lejos de sus limitaciones, morales, religiones y política.

6. Regrese a sus principios de periodismo.

7. Opte por las víctimas. Tenga cuidado con la revictimización. No prometa ayuda.

8. No culpes ni cuestiones a la víctima.

9. Recuerde la contextualización.

10. Verifique los riesgos y los impactos de escribir un informe. \#PerDebate17 
Lara Whyte,

Productora y periodista de investigación de Vice y Open Democracy (Reino Unido)

\section{Conferencia Magistral: "Desafíos en la cobertura de los derechos reproductivos y las comunidades LGBTI"}

Miembro de Belfast en Irlanda del Norte, ha tenido muchos trabajos. $\mathrm{Su}$ trabajo independiente y su trabajo como editora de comisionado. Mostró algunas de sus historias más importantes como periodista independiente.

Como periodista independiente es clave encontrar historias que nadie más está cubriendo y esto es lo que la llevó a trabajar en la investigación. Pasó 7 años trabajando para un locutor de noticias comerciales en el Reino Unido e hizo muchas historias en las que no tenía ningún interés. Su primera gran historia fue sobre las niñas secuestradas por el ISIS en el norte de Irak y Siria. Todas las historias mostradas en la pantalla eran de personas que conoció en Facebook. Primero comenzó a registrar los testimonios de las chicas que fueron secuestradas por el ISIS pocodespués de que ocurriera en 2014y2015. Por lo tanto, estaba bastante frustrada porque la historia no estaba recibiendo la atención que merecía y en 2015 en Europa fue la crisis de refugiados y todos los días se veían imágenes de familias que ingresaban por mary ahíes dondela mayoría dela prensa concentraba su atención.

Usando información de fuente abierta que fue recopilada por la ONU, pudo lograr que solo el 13\% de las personas del norte de Irak que ingresaron a Europa fueran mujeres. $Y$ en el momento en que eso no se reflejaba realmente, decidió hacer el viaje de regreso a Norther Irak para averiguar dónde estaban estas mujeres, dóndeseibanylas condiciones que padecían. No fue al frente en el norte de
Irak, era bastante cercana, pero todos los demás periodistas de la región lo hacían, por lo que no tiene ningún valor ser un profesional independiente para ofrecer una historia a un periódico o a un locutor, algo que puedan conseguir para ellos mismos. Si los medios del mundo se enfocan en un solo lugar, es necesario que mires en la dirección opuesta. Entonces, conoció a Nadia y la entrevistó a ella y a muchas otras mujeres de forma anónima y cuando la entrevistó, se dio cuenta rápidamente de que estaba registrando testimonios de crímenes de guerra y no había un organismo oficial al momento de registrar estas historias, por lo que tuvo que haber recibido muchos consejos de psicólogos, grupos de defensa de los derechos de las mujeres, para no volver a traumatizar a la víctima.

En particular, muchas de las niñas de esta comunidad en los primeros días en que se liberó el cautiverio ISIS se suicidaron, y eso se debe a la cultura de la vergüenza dentro de su propia comunidad. Entonces, en el centro de su historia, tuvo mucho cuidado de llamar a los sobrevivientes y centró sus entrevistas en la historia de escapar en lugar de victimizarlos y verlos como víctimas en oposición a los sobrevivientes. Nadia, por ejemplo, su historia es que saltó de un edificio a otro y trepó por una ventana y sobre una valla y su historia de sobreviviente su historia de escape es en realidad mucho más positiva para ella contar y detallar los métodos de tortura que vivió. Ese encuadre a través de lentes de género 
realmente pareció tener un impacto en las redes sociales y se volvió viral, lo cual es genial cuando eres un profesional independiente porque es bueno para tu ego y si se traduce puedes obtener más dinero.

Entonces, Nadia ahora es embajadora de la ONU, después de que se publicó ese artículo le ofrecieron un libro que acaba de ser lanzado y ella realmente tiene un editor de libros en Ecuador. Ese es un ejemplo de cómo una historia que comenzó en Facebook y si es una buena historia puede traducirse a todos los medios. A través de esta historia, descubrió que había ejércitos de mujeres que habían sido capturadas por ISIS y que luego se unían a la lucha contra ISIS. Por lo tanto, estas chicas estaban luchando por venganza y ella tenía mucho respeto, por su motivación y algunos de estos ejércitos también reclutados de Europa, por lo que la historia "la chica que huyó para luchar contra ISIS" fue otra buena historia y ahora esta chica también está escribiendo un libro conmigo.

Hay otra historia de Ébola, de la que Lara quería hablar, sobre el impacto a largo plazo del desastre visto a través de lentes de género. Durante la crisis se informó mucho comportamiento predatorio. Entonces, ella fue a Sierra Leona y descubrió una expresión "agua por agua". Lo que eso significaba era que las niñas tenían que ir a buscar agua todos los días y había una gran campaña pública, tenían que lavarse, tenían que mantenerse limpios, por lo que iban a conseguir agua, pero alrededor del agua, los hombres estarían allí, y no les permitirán recoger agua a menos que cumplan para ser violadas. Entonces, estas jóvenes fueron puestas en elecciones absolutamente imposibles, ya sea que cumplan con la agresión sexual o que arriesguen a su familia contra elÉbola. Cuando hablaste con ellos, esa fue literalmente la elección que hicieron y, por supuesto, cumplir con el asalto sexual.

Entrevistó a una docena de niñas que eran madres adolescentes y esa fue la verdadera historia que recibió sobre el embarazo adolescente, pero en el momento en que llegó allí, obtuvo esta otra historia de la razón por la que estaban embarazadas porque estos asaltos sexuales predatorios que tenían para soportar. En Sierra Leona, de acuerdo con la ley, una vez que queda embarazada, debe abandonar la escuela. Ser una madre adolescente es un desastre absoluto ya que la escuela cree que usted será una mala influencia para el resto de los estudiantes. Entonces, las ONG que estaban trabajando en este país, lograron que el gobierno terminara con esta ley, así que una vez que quede embarazada, no tiene que dejar la escuela y esta pieza y otras 5 que hizo allí, fueron usadas como parte de esa campaña. A ella le encantaría decir ahora que la ley ha cambiado pero no es así, es solo parte de una campaña y con suerte lo hará.

Mucho de su trabajo se trata de desafiar las leyes que son patriarcales en su definición y en su práctica. Se proyecta un vídeo que hizo para los derechos de aborto en Irlanda. No por la constitución, que se llama el 8 de modificación, la vida de las mujeres es el mismo valor que su hijo no nacido, por lo que el aborto es ilegal. El presentador es joven, y el estilo de Vice es involucrar a un presentador en una protección, no afuera, denunciándolo. En las redes sociales, esto funcionó muy bien con su público, que suele ser menor de 35 años, por lo que llevamos al público a través del viaje del presentador.

El trabajo de Lara Whyte en general habla sobre los derechos de las mujeres y no tiene ninguna disculpa por eso. Y la razón por la que puede hacer eso es porque viajó muy bien en las redes sociales. Entonces, desde el punto de vista de un editor, recibe muchos clics y hay un público activo al que le gusta escuchar este tipo de historias. Ella tiene este tipo de audiencia joven que los anunciantes quieren, $\mathrm{y}$ todos quieren.

Entonces, Whyte comenzó a hablar de 50.50. la sección de género de Open Democracy, una 
plataforma global de medios independientes que cubre el género, la sexualidad y la justicia social. Ella es feminista y feminista cree que el hombre y la mujer deben ser iguales y 50-50 cree en la igualdad de participación de hombres y mujeres en todos los aspectos de la vida pública y la misma responsabilidad con los hombres en nuestras vidas privadas.

La investigación de este año es rastrear la reacción violenta en todo el mundo contra los derechos de las mujeres. Los derechos de las mujeres y los derechos de las personas LGBTI están bajo amenaza debido a las crecientes y globalizadas redes de grupos religiosos, y lo hacen bajo la guía de ser "pro familia". Whyte mostró parte del trabajo que está haciendo, mirando cómo están funcionando estos grupos, y los está mirando a través de una perspectiva global, pero es muy complicado su trabajo muy delicado porque estos grupos están interconectados, y la primera línea de su batalla es en las redes sociales. Tienen planes estratégicos a largo plazo fuera de línea y a menudo armaban esta infraestructura de organizaciones religiosas.

Comenzaron este año en Hungría, asistieron al congreso mundial de la cumbre familiar donde cientos de antiabortistas y anti LGBT se reunieron para hablar sobre los derechos de las familias y cómo proteger sus derechos. Cuando dicen los derechos familiares, eran muy explícitos, significaban madre, padre e hijos, por lo que esta es la única definición de familia que aceptan. Por lo tanto, están en contra de la educación sexual, contra el aborto, contra el matrimonio entre personas del mismo sexo. Vieron sus estrategias de comunicación y cuán activos son. Han tenido cierto éxito en la organización y vinculación con otros grupos internacionales y eso está teniendo un gran impacto sobre el terreno. $Y$ están haciendo muchas conexiones, particularmente en África, donde se ponen de pie los intentos de la ONU de colonizar África e imponer el imperialismo a través de la educación de las mujeres. Entonces, el impacto sobre el terreno es muy serio, a pesar de que el alto nivel de la ONU parece algo distante de lo que están viendo realmente en el terreno es lo que están investigando. El tono es todo acerca de la privacidad, el derecho a la familia y todo suena muy bien poco es en realidad muy siniestro. Se trata de mujeres que mueren en un aborto inseguro o de un parto y se trata de tener matrimonios infantiles y madres infantiles. Y entonces, cuando dicen que es una guerra contra la mujer, es una guerra contra el progreso, los derechos y contra los derechos.

Lara Whyte nos mostró una imagen de uno de los grupos principales en los que se están metiendo, se llama Hazte Oir. Tienen un gran impacto en el Reino Unido este año, hubo un caso muy triste en el que un bebé se estaba muriendo y su familia fue al hospital para tratarlo. Este bebé se llamaba Charlie y hubo una gran campaña, movilizando todo en el Reino Unido para proteger los derechos de la familia contra el Estado que intenta matar a Charlie, lo que era absolutamente falso. Comenzaron muchas peticiones y obtuvieron millones de firmas, que revisó estas peticiones y hubo una gran cantidad de firmas falsas. Tienen muchas campañas en las redes sociales donde son principalmente muy activas y lo que ella hizo fue evaluar algunos de los hashtags y descubrió de dónde eran, por lo que afirmaban que era una campaña del Reino Unido cuando en realidad la mayoría de los los hashtags venían de los Estados Unidos y extrañamente Brasil. Entonces, en realidad, la minoría de ellos era del Reino Unido. Continúan esta lucha e intentan cambiar la ley, pero ella cree que muestra el cinismo de este grupo para aprovechar el dolor de una familia para expresar un punto legal.

Se llaman a sí mismos el mayor grupo social de América Latina y han estado en Ecuador desde 2013, y en Perú en este momento están tratando de acusar a dos parlamentarios porque retuitearon sobre la violación en el país y lo consideraron ofensivo. Aquí en Ecuador fueron parte de la protesta por "no te metas con mis hijos". Y están tratando de llevar 
ante los tribunales a un activista de los derechos de los homosexuales que afirma que esta protección fue una protesta de odio. La ironía es que están utilizando leyes de diseño para proteger los derechos contra su lucha.

En Estados Unidos, grupos similares como estos están creciendo dirigidos específicamente a las mujeres afroamericanas y lo que están haciendo es utilizar el lenguaje del movimiento Black Lives Matter para atraer a las mujeres afroamericanas que desean ejercer sus elecciones reproductivas. Están haciendo eso a través de Facebook, en particular, y a través de la focalización activa de una manera muy inteligente que usarán principalmente las compañías de marketing. Entonces, solo para decir que la pieza que nos mostró era una pieza de comentario, todavía hicieron una búsqueda en Facebook y obtuvieron una periodista afroamericana para escribir la pieza. Porque se dieron cuenta de que su perspectiva es europea, y quieren trabajar en un contenido global e interseccional. Entonces, Whyte como mujer irlandesa experimentará un patriarcado diferente al de las mujeres ecuatorianas.

Hay algunas buenas investigaciones sobre quién está escribiendo historias, incluso sobre temas de mujeres, y fue una estadística interesante que descubrieron, por lo que las mujeres solo escriben el $37 \%$ de las historias reproductivas, mientras que los hombres escriben el $52 \%$. Así que esa fue la cobertura de los principales medios de comunicación y lo que ellos creen que muestra que la mitad de la cobertura del embarazo y la elección reproductiva ha sido escrita por una parte de la población que no puede quedar embarazada. $Y$ entonces, creen que muestra la ironía de los medios de comunicación para cambiar y para que los hombres vuelvan a su carril y nos hagan los nuestros y, en general, reduzcan un poco la velocidad.

Hay muchas páginas de noticias sobre mujeres, pero ¿dónde están las investigaciones feministas reales? Por lo tanto, han identificado esta necesidad, es lo que están tratando de hacer en el momento. A menudo, las mujeres están en primera línea en todo el mundo, pero sus voces faltan en muchas investigaciones. Los defensores de los derechos humanos de las mujeres están siendo asesinados en todo el mundo, sin embargo, muy pocas investigaciones que analizan por qué se está matando a los defensores de los derechos humanos se ven desde una perspectiva de género. Y así, un ejemplo de esto es que examinamos los derechos sobre la tierra, las mujeres que protestan a menudo son atacadas dos veces, una porque están allí y, en segundo lugar, como una forma de atacar a los hombres, para que puedan ser objeto de agresión sexual como forma de conseguirlo.

Finalmente, Lara Whyte señala que los grupos que están investigando representan una amenaza para los derechos de todas las mujeres y muchos hombres, pero en lugares donde los derechos reproductivos no están protegidos, los riesgos son mucho mayores, por lo que como feminista, periodista de investigación, su objetivo en este proyecto es investigar cómo sucede esto en el terreno y se dan cuenta de que no tienen suficientes vínculos en toda América Latina.

\section{\#PerDebate17}

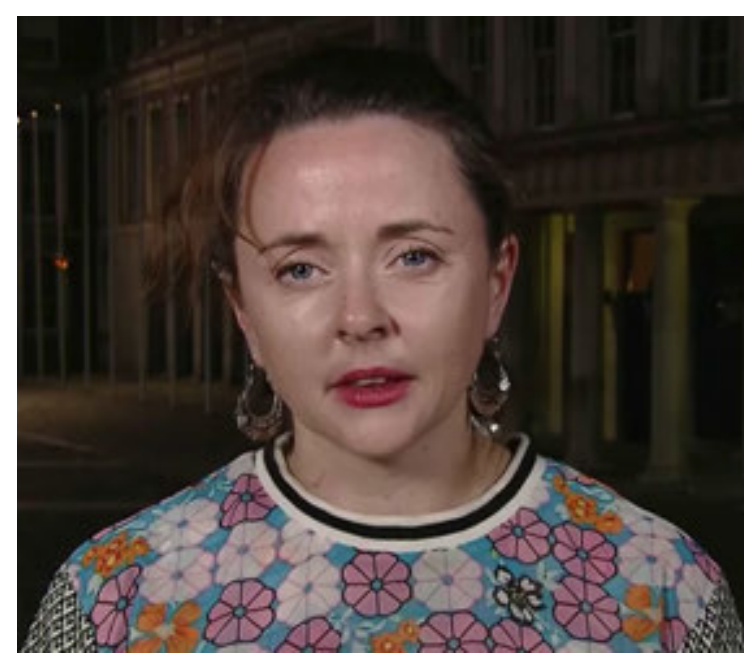


Foro,

Participantes: Cécile Mégie, Lara Whyte, Verónica Larrea y María Dolores Miño

Moderadora: Ivonne Gaibor

Volver al índice - English Version

\section{"Liderazgo Femenino en los Medios"}

Ivonne Gaibor: Este es un gran tema en Ecuador. Revisé un tweet publicado por el nuevo jefe de los medios públicos, Andrés Michelena, hacía referencia a una reunión que tuvo con el Ministro de Industrias. Lo relevante de ese tweet fue la imagen con solo una mujer allí, que era Ministra de Industrias. Me llamó la atención. Más tarde, pensé que en los periódicos donde trabajé años atrás, hay dos mujeres editoras de sección. Y es lo mismo en otros medios. En El Comercio solo el $20 \%$ de los editores son mujeres. E incluso creo que es un problema que se repite en todo el mundo, pero lo importante aquí, en Ecuador, es comenzar a hablar de esto. No encontré demasiada información sobre la situación de las mujeres en jefe de medios en Ecuador, así que creo que es el momento de comenzar a hablar sobre este tema aquí. La primera pregunta es, ¿cuáles son las dificultades que encuentran las mujeres periodistas para acceder a los puestos principales y liderazgo en los medios?

Lara Whyte: Son muchas razones. El sexismo es clave. Hay muchas mujeres de mi edad enlos medios que cuando somos un poco mayores es difícil mirar a los directores debido a las responsabilidades. Se dieron por vencidos, ya sabes, las responsabilidades familiares se hacen cargo y cambian, y se dan por vencidos.

Verónica Larrea:Sí, estoy de acuerdo. Desafortunadamente, y esto no solo está en los medios sino en muchos otros negocios, públicos y privados. Siento que hay algo mal en el significado del igualitarismo de género. Mucha gente dice que "las mujeres tienen los mismos derechos que los hombres porque ahora pueden trabajar, por lo que cualquier mujer tiene la misma posibilidad de ocupar un puesto de trabajo que un hombre".

Cuando una mujer quiere conseguir un trabajo, podemos ver que no es verdad ¿Hay una posibilidad real para que

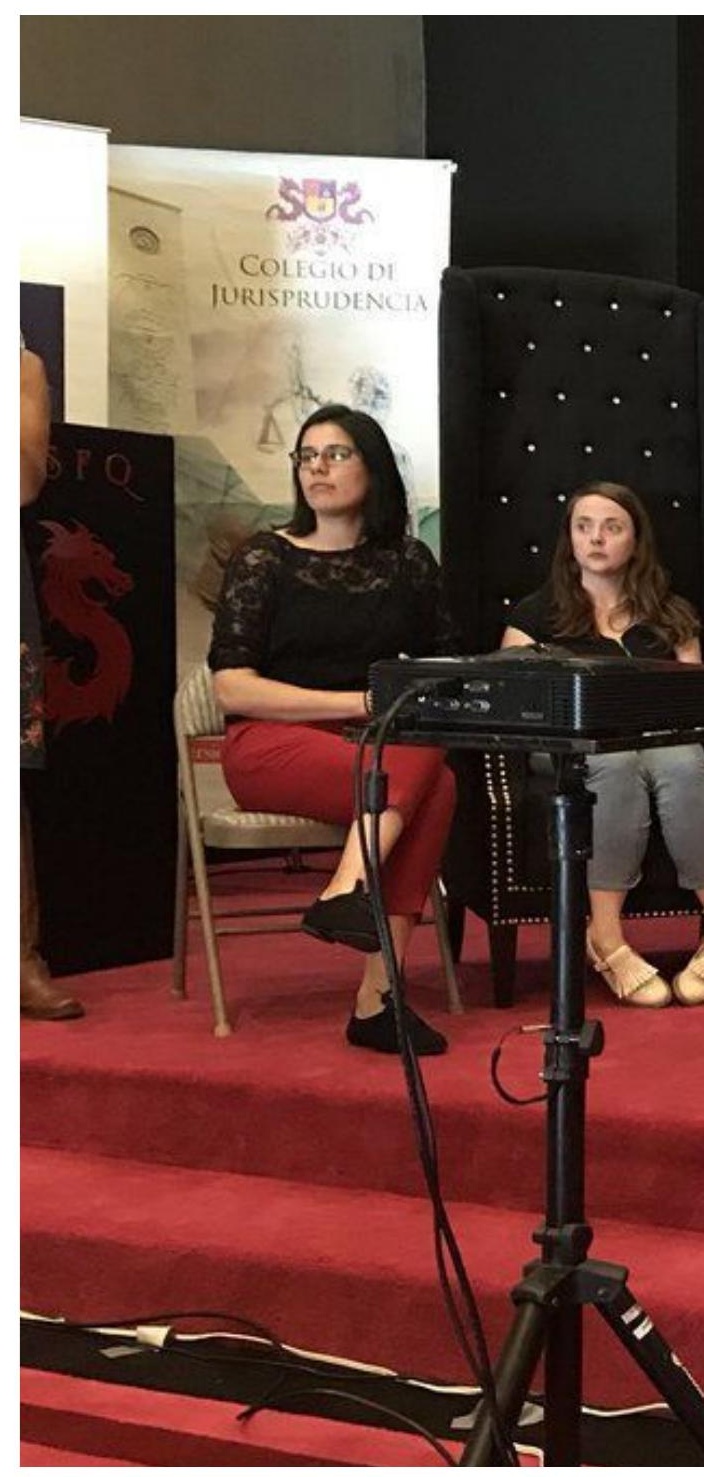




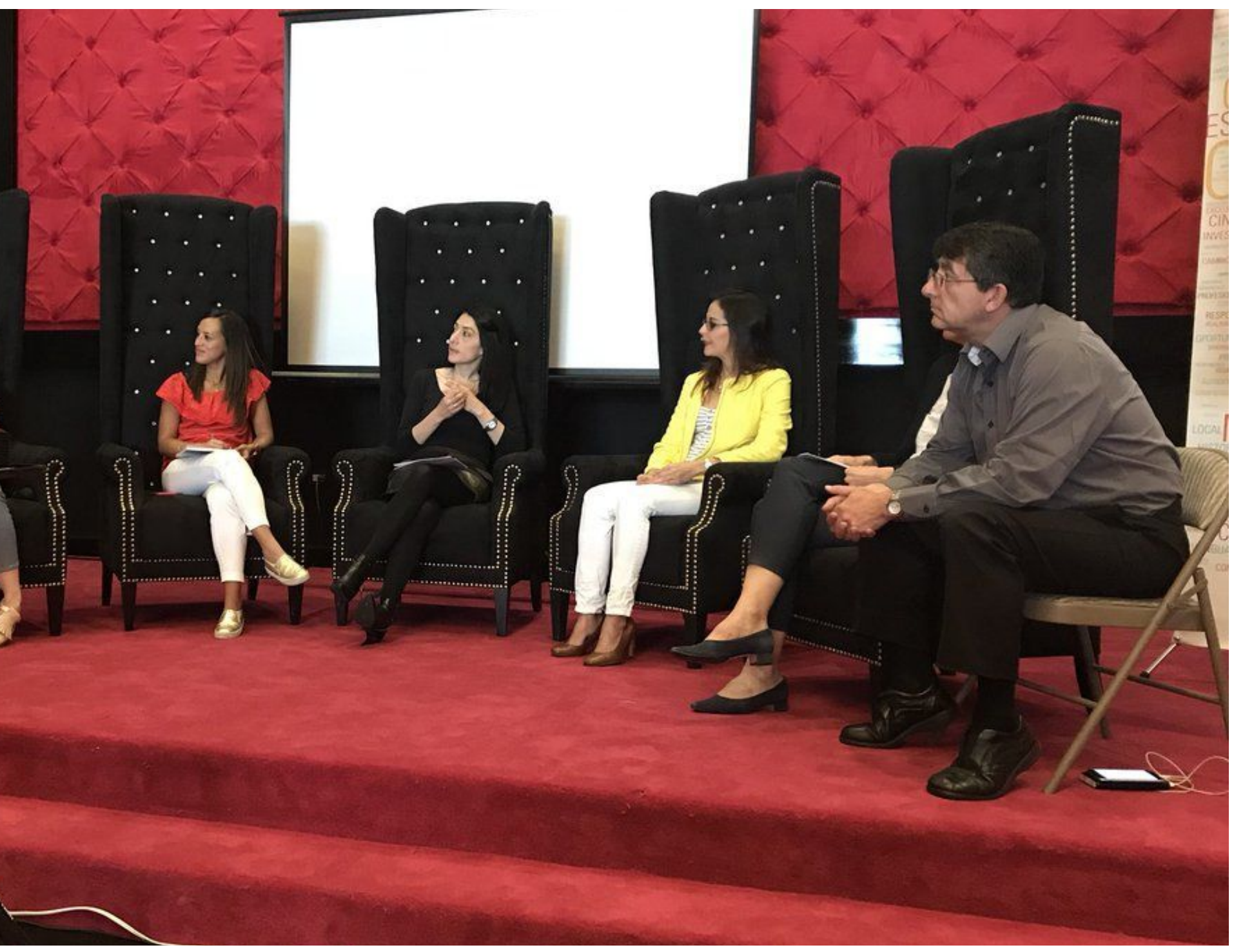


Son momentos cruciales para la igualdad en todo sentido. El liderazgo femenino se sigue expandiendo a los distintos círculos y labores sociales, por lo que su desempeño en los medios actuales es fundamental para la construcción de una sociedad más justa.

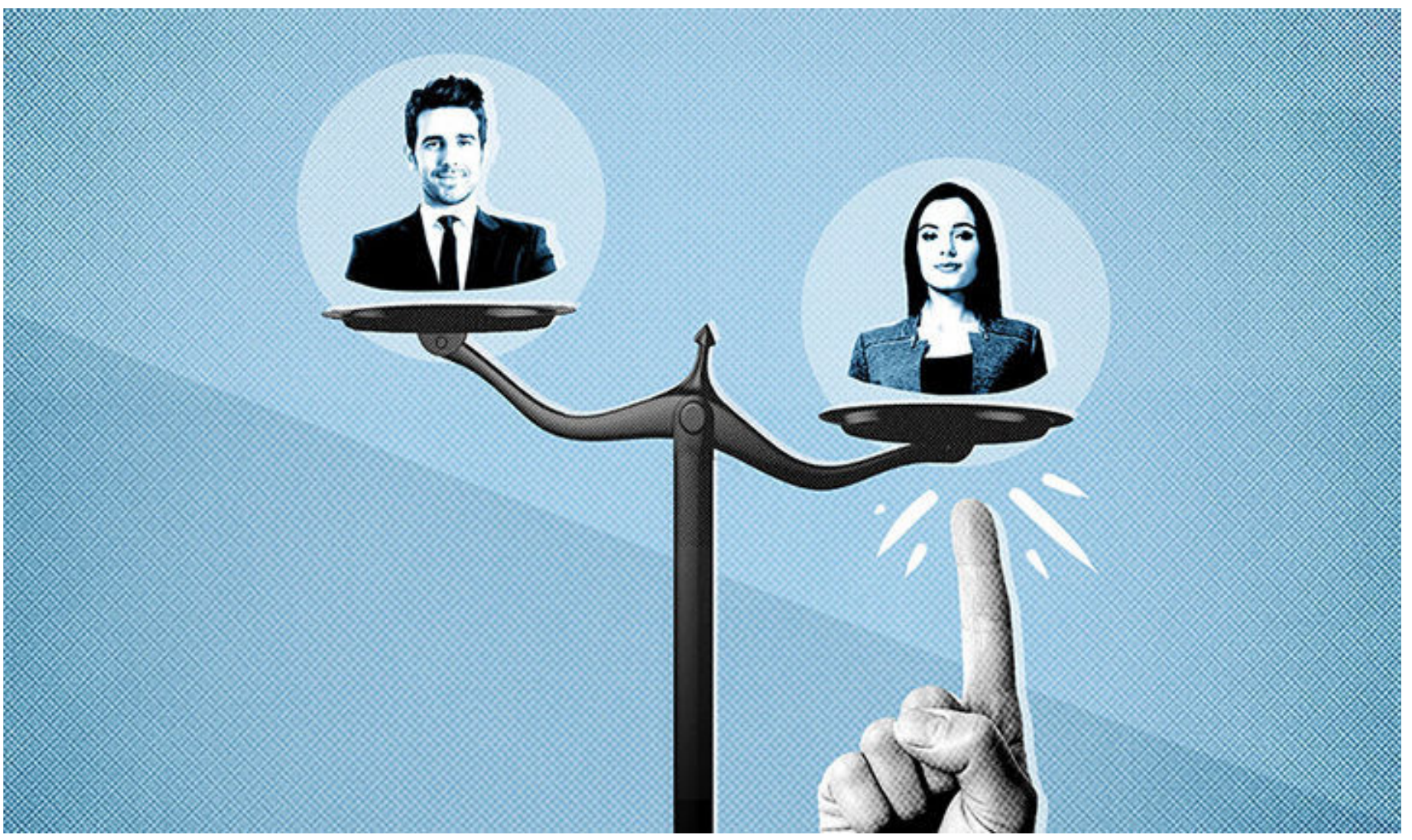

las mujeres tomen una posición de liderazgo? Muchas veces cuando las mujeres tienen 30 años, nuestras vidas cambian, tenemos que dividir nuestras responsabilidades y si estos medios no adaptan la forma de trabajar para permitir que las mujeres tengan sus propias responsabilidades, no hay otra manera que dejar un trabajo. Entonces, para mí, la pregunta es cómo adaptamos los puestos de trabajo para que sean compatibles con las responsabilidades de las mujeres, ya que es la familia, la pareja $y$, ¿por qué no el tiempo de recreación también?

María Dolores Miño: Bueno, Ivonne ya expuso una realidad. Las mujeres no ocupan los puestos principales. La iniciativa en la que trabajo, Chicas Poderosas, está buscando que esto suceda. Hay muchas dificultades y creo que todo parte de la sociedad. Esta sociedad patriarcal que ha puesto el trabajo de las mujeres en un segundo plano. Los hombres son el proveedor y las mujeres tienen que estar a un lado. Creo que esa premisa tiene que cambiar y ha comenzado a cambiar. Debido a que las mujeres son tan capaces como los hombres, sin embargo, no nos hemos dado la oportunidad.

Es necesario tener la mentalidad de que podemos hacerlo y podemos valorarnos a nosotros mismos para hacer que la sociedad entienda que eso se puede cambiar. Entonces, las dificultades son muchas. Una gran cantidad de problemas de dominio masculino. Los hombres no respetan a las mujeres a cargo. Entonces, el cambio viene de valorarnos a nosotros mismos para cambiar nuestra realidad.

Cécile Mégie: Soy muy afortunada. Trabajo en un país y en un medio donde las mujeres llegaron muy alto. Todavía tenemos que 
progresar, pero ya hay cosas hechas. Hablé con Betsi y le comenté que los franceses son buenas figuras en ese plan. Las mujeres deben tener confianza en el hecho de que pueden hacer esto en la administración de una sala de prensa con unas 415 personas $y$, a veces, cuando quiero promocionar a una mujer, no porque sea una mujer, sino porque tiene las buenas habilidades y el buen perfil a una nueva posición. Tengo que convencerla de que es posible para ella y hacer que confíe en que lo logrará, incluso si tiene hijos pequeños, incluso si tiene una vida familiar que quiere mantener, es normal, entonces creo que las mujeres tienen que decir, vale, lo intenté. $Y$ nosotras como gerente, tenemos que gestionarlo de la manera en que hace el muy poco común en Ecuador. Nunca podemos imaginar que algo así suceda, pero es bueno saber que en los países europeos estas cosas ya están sucediendo. En el caso personal, durante muchos años trabajé en una sala de redacción donde era fácil notar las diferencias entre hombres y mujeres. Sentí esta relación de poder que viene sobre la sociedad y un imaginario social. Las cosas que aprendemos desde niños y durante años solo siguen sucediendo. Además, también sentí que, desde el punto de vista de otras mujeres, sentí la misma rivalidad. Es impresionante. Tenemos que cambiar eso, y estamos aquí para cambiarlo. Es el momento de hacerlo y estar aquí debatiéndolo ya es un paso.

... No soy periodista, soy abogada, pero he trabajado muy de cerca con los medios y realmente disfruto escribiendo algunas columnas de opinión Mi sensación ha sido que las mujeres tienen un lugar mientras nuestras opiniones no entren en conflicto con lo que piensan los hombres en general. María Dolores Miño: Sí. No soy periodista, soy

trabajo. Pero como gerente soy muy cuidadosa de cómo se desarrolla la mujer.

Hoy en día, nadie puede aceptar que, en una imagen, sea cual sea el tema, solo haya hombres. Cuando vas a las redes sociales ves a veces, y tienes que ser muy sensible a este hecho. El $51 \%$ de la humanidad son mujeres, porlo que tienen que aparecer en todaspartes, sea cual sea el tema.

Cécile Mégie: Estoy en esta sala de redacción durante 25 años y no fue tan difícil. Sé que el CEO de FRI es feminista, es militante y tiene tres directores para nombrary desea nombrar a mujeres y hombres. Por lo tanto, es una entrada que imponen, hay mujeres en la parte superior de la PF de radio. Antes de ser el directora de FRI, yo administraba el servicio de economía, y un día me di cuenta de que solo tenía mujeres en mi servicio, me comunicó con el director le digo "por favor, dame hombres en el servicio, no es adecuado trabajar así". Estoy segura de que tenemos que trabajar juntos. Tenemos que vivir juntos, y tenemos que trabajar juntos.

Verónica Larrea: El caso que expuso Cécile es abogada, pero he trabajado muy de cerca con los medios y realmente disfruto escribir algunas columnas de opinión para algunos periódicos. Mi sensación ha sido que las mujeres tienen un lugar siempre que nuestras opiniones no entren en conflicto con lo que piensan los hombres en jefe. En Ecuador, veo que muchas organizaciones, medios $y$ fundaciones tienen un vínculo muy fuerte entre el jefe y las organizaciones, por lo que cuando cuestionas a una institución es como cuestionar al jefe y eso genera conflictos.

Ha pasado casi un año de que dejé de escribir una columna en un periódico porque vivía una situación como esa. Mujeres periodistas, de unos 32 y 36 años, a mi lado lucharon contra este periódico ya que no acordamos una decisión editorial. Nos trataron como niñas pequeñas que no tenían sentido. Entonces, después de eso, mi percepción es que no existe el hábito de cuestionar el liderazgo masculino. Después de esto, todo lo que pregunté con mis otros colegas es hasta qué punto la diferencia de género aún está 
presente y el temor tienen algunas mujeres al cuestionar el dominio masculino.

Es común pensar que las mujeres sienten que no están preparadas para asumir algunos roles de liderazgo en la sociedad. Siento que cuestiono mi trabajo y mis capacidades y luego veo hombres con menos conocimiento que yo haciendo el trabajo porque tienen una sociedad completa que los respalda. E incluso a veces, las mismas mujeres están a cargo de disminuir su propio sexo. Si usted, como mujer, comienza a tener un perfil público, de inmediato no podrá hacer otras cosas o no se ocupará de otras, y la culpa que algunas mujeres sienten es la que hace que las mujeres abandonen puestos de liderazgo importantes. La dominación masculina no es solo que los hombres tomen el control sino las mujeres que repiten estos patrones.

Ivonne Gaibor: Lara, por favor, ¿cómo fue tu relación laboral con los hombres?

Lara Whyte: Bastante buena en general, para ser honesta. Creo que es mucho más sutil el sexismo que obtienes en los medios en el Reino Unido. $Y$ hay algunos problemas en particular como una periodista joven para hacer muchas más cosas de celebridades o cosas tontas de la realeza, pero creo que es mucho más sutil ser honesto. Dentro de las organizaciones con las que trabajé, ha habido al menos una mujer de alta gerencia que es algo agradable de ver como mentora. Y lo mejor de ser autónomo es que no tienes que lidiar con el drama interno, así que solo tienes que escribir tu historia y listo.

Ivonne Gaibor: Lara ¿has sentido que en una posición de liderazgo has tenido que destacar tus habilidades y te has sentido cuestionada en alguno de estos roles?

Lara Whyte: Sí, absolutamente, pero creo que la primera persona normalmente soy yo ¿Soy lo suficientemente buena para hacer esto? También encontré que cuando soy editora, nunca me gustaría hablar, cuando estaba escribiendo, nunca habría hablado con un editor de la misma manera que la gente me ha hablado. Están editando mis ediciones. Y no sé si es porque soy paranoica, porque soy una mujer, pero nunca hubiera tratado a alguien de esa manera.

María Dolores Miño: Sí, siento que como mujeres asumimos que no podemos. $Y$ también me he encontrado en muchos espacios donde no me han notado. Siento que en las sociedades latinas tenemos esta presunción de ser menos capaces, lo que también nos ayuda a ser más precisos en lo que hablamos, estar más dispuestos a cualquier cosa, por lo que nuestro trabajo se vuelve más rico y finalmente esta calidad se ve $y$ tiene un efecto positivo en nuestra experiencia.

Verónica Larrea: Lo he sentido. Comenzando en uno mismo para convencernos de que somos capaces de hacerlo y para convencer al resto de la gente de que podemos hacerlo. $A$ veces, nos enfrentamos en situaciones donde tenemos una figura masculina dominante que no te permiten cuestionar. Es una gran lucha convencerse a sí mismo y luego convencer a su equipo y a la gente de que usted es capaz.

Cécile Mégie: Sí, he dicho que no todo está hecho en Francia y este tipo de pregunta es inmóvil, e incluso en mi compañía. Debo señalar que tal vez en una reunión con mujeres y hombres es muy frecuente que los hombres tomen el discurso con más facilidad que nosotras, incluso yo, y cuando diriges esta reunión tienes que ser muy consciente de quién está tomando el habla y quién habla y cuándo, y a veces hay mujeres que tienen una buena idea pero la que dicen en voz muy baja. $Y$ los hombres justo detrás de ella toman la idea y la dicen más fuerte, por lo que debes reconocer quién dijo la buena idea y decir "gracias, señorita".

Y lo segundo es tal vez en los salarios, los ingresos. Creo que los estudios son aproximadamente 20 o $30 \%$ en el mismo 
trabajo entre hombres y mujeres en promedio. En RFI no es tan alto, es mejor que el promedio, pero hace unas semanas nombré a una mujer justo detrás de mí, la subdirectora, y tuve que pelear con el director general para decirle que quería que se la pagara como el hombre que ella estaba reemplazando. Y no fue tan fácil, así que aún creo que tenemos tanto progreso que hacer y aún tenemos que convencer a las mujeres tal vez en el trabajo que estoy haciendo ahora, mi responsabilidad es mirar esto todo el tiempo y no dejar que ninguna desigualdad las defina.

Ivonne Gaibor: Sí, exactamente el tema del nido del que quería hablar, los salarios. Tenemos una gran diferencia en los salarios y podemos hablar de lo que está sucediendo en Francia y Ecuador. Estamos viviendo una gran diferencia salarial.

Verónica Larrea: Exactamente de lo que se habla, Cécile, sobre reproducirse en el país, quisiera entender por qué las mujeres son capaces dehacer el mismo trabajoy recibir un salario menor. Tal vez porque las mujeres pueden ser madres y me faltan muchas. Es algo que realmente he tratado de entender, pero simplemente no hay respuesta o razón.

María Dolores Miño: Las mujeres todavía se ven como una debilidad comercial. Algo que no vale la pena invertir ya que al final se irá. Si eres una debilidad para el negocio porque eventualmente serás madre. La siguiente acción es no contratar mujeres y para la expulsión, medios de comunicación, perdería esta voz femenina y el punto de vista que enriquece su contenido multimedia. Entonces, la pregunta es realmente, cómo adecuo mi estructura con el fin de trabajar con los nuevos roles de hombres y mujeres, porque las mujeres no son solo cuidadoras y los hombres no son solo guardianes. Esto nos llama a preguntarnos qué hacer para cambiar esta estructura y adoptarla al presente.

Lara Whyte: Creo que es un poco diferente cuando trabajas por tu cuenta, pero no por las cosas clave que evitan que las mujeres pidan más dinero. $Y$ también, como editor cuando alguien me lanza un mensaje, no piden un montón de dinero, tengo un presupuesto y pienso "sí, puedo usar ese dinero en otro lado". Entonces, en términos de que obtengo más de mi salario, casi me atrevo a pedirlo y me doy el doble del salario y lo hice porque no necesitaba el trabajo, así que es un ejercicio realmente bueno, y ahora solo aumento mi salario.

Ivonne Gaibor: Tenemos que empezar a terminar, pero realmente no quiero dejar atrás una pregunta que tuvimos allí, es decir, bueno, Lara, Cécile y Vero tienen más experiencia en producción de contenido. ¿Cómo crees que cambia la producción de contenido en las noticias con una mujer a cargo?

Lara Whyte: Creo que hace que sea más fácil para una mujer que quiere ver. Estamos pensando en una participación de la audiencia, las mujeres están aburridas viendo las viejas representaciones de ellas mismas. Por lo tanto, realmente mejora su capacidad de contar historias cuando una mujer participa en cada etapa, trabajando con hombres. No creo que cambie por completo pero creo que solo añade más textura y mucho más profundidad en la historia.

Verónica Larrea: Hablando del contenido de noticias no tendría que cambiar mucho si somos responsables y hacer el informe. Pero a medida que las mujeres, que son un poco más detallista, podemos tener diferentes puntos de vista y podemos dar ese aire fresco al informe. En términos de opinión, creo que es un poco difícil en el caso porque las mujeres tenemos una visión diferente del mundo. Eso crea diversidad y debate. Pero, lo que realmente creo que cambia en el contenido son las personas que se reflejan en las noticias. Y yo estaba mirando algunas estadísticas muy interesantes de las mujeres de la ONU y veo que las mujeres que aparecen en la televisión son víctimas o celebridades. Pero las mujeres líderes políticas no están 
siendo parte de ese contenido. Ese es un tema interesante que nos lleva a preguntarnos si somos parte de la sociedad, ¿por qué no somos otra cosa además de víctimas?

Cécile Mégie: Debemos tener cuidad, mujeres y hombres, que el discurso no sea un discurso sexual. Las mujeres no deben ser solo víctimas o testigos y en los medios de comunicación franceses las autoridades de los medios, los reguladores, nos imponen registrar las estadísticas de cuándo hablaron las mujeres. $Y$ tenemos que tener habilidades especiales para buscar expertos mujeres. En RFI, tengo que dar dos veces al año las estadísticas de cuánto hablaron los expertos en mis programas. Y se me ha dado objetivos y si no cumplo con este objetivo voy a ser menos pagada. Por lo tanto, esta es una empresa política y yo, y el director hombre de RFI las 24 horas tiene que hacer su trabajo también. Pero no se trata solo de dinero, sino que tenemos que dar un gran impacto e información a nuestro colaborador, el discurso de las mujeres también como discurso de expertos y no solo como víctima o testigo. es que tiene que hacer algo que ver con la forma en que nuestra sociedad es izada de órganos, sólo un ejemplo. Tengo un programa sobre salud al que asistieron muchos médicos y especialistas, y el productor de este programa que es una mujer. Estaba segura de que tendría buenas estadísticas sobre este programa y luego las contó y tuvo muy malas estadísticas. Y eso no fue su culpa, quiero decir que todos los grandes responsables en hospitales y maestros en salud son hombres. Por lo tanto, si ella quiere que haya mujeres como expertos que tiene que entender este problema y tratar de tener las mujeres más jóvenes tal vez, no tan grandes en la responsabilidad, pero tiene que ser muy voluntario en esto. $Y$ creo que no es solo un problema de estadística, es un problema de logística de lo que estamos haciendo y de cómo lo que hacemos primero podemos hacerlo mejor. Lo mismo en política.

Pero para ser honesta, lo que es bastante difícil

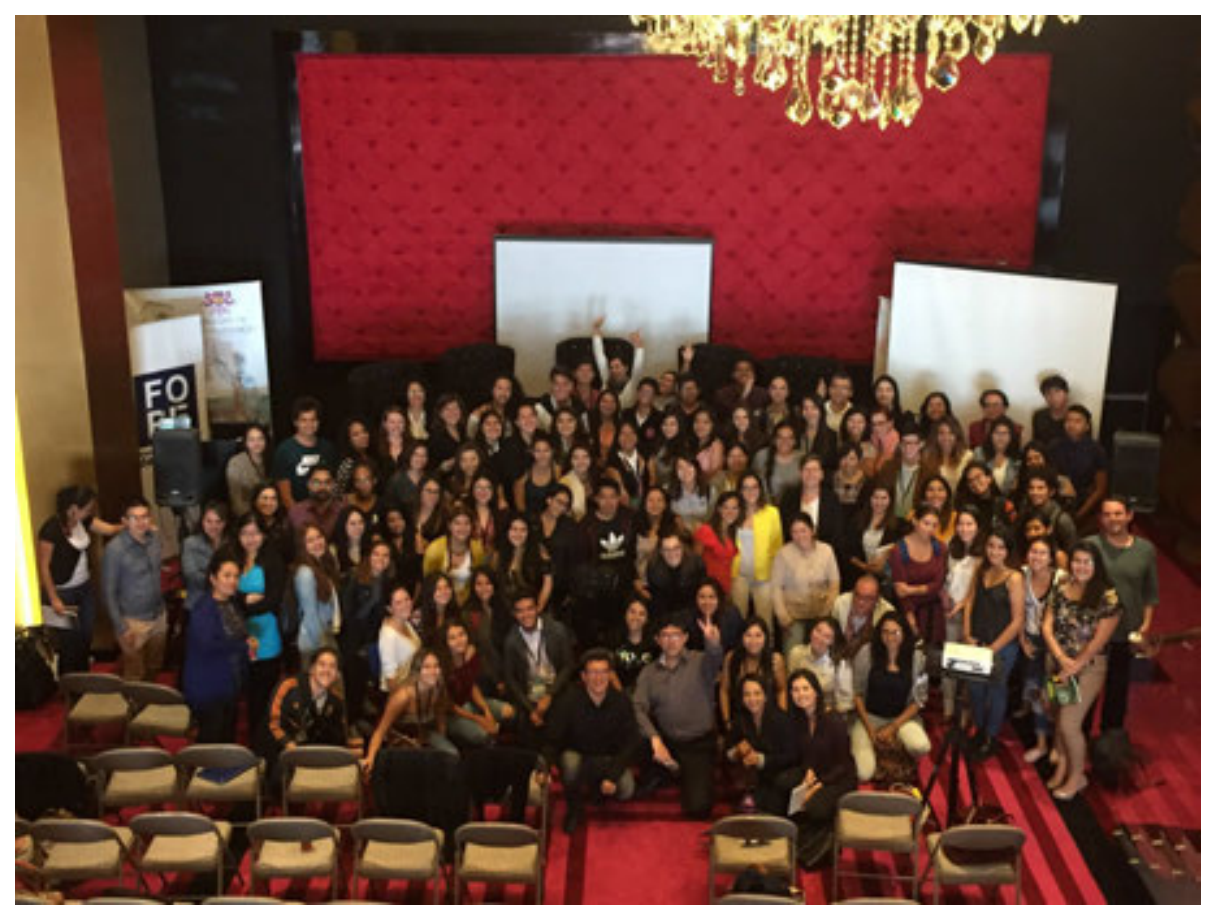





\section{Index \\ English Version}

\section{Page 97}

Cécile Mégie - International Vision for Local Contexts

\section{Page 102}

Susana Morán - A Digital Community led by Women in Latin America

\section{Page 105}

Carlos Ponce - Lights and Shadows of the Real Situation of Press Freedom in Latin America and the World

\section{Page 110}

Tom Sanderson - Research Capabilities for Journalists Working in Local Communities

\section{Page 116}

Forum - Investigative Journalist at all Cost

\section{Page 128}

Cristoph Geiseler - Video Production in Viral Micro Tales, a Macro Tendency

\section{Page 134}

Toa Maldonado - Intercultural Production of Otavalo

\section{Page 137}

Bélgica Calderón - The Challenges of Ethnic Diversity in Public Media

\section{Page 141}

Betsi Grabe - Gender Coverage in the Media

\section{Page 147}

Forum - Academic Research in Gender and Media Practices

\section{Page 153}

Ariel Dulitzky - Empowerment and Human

Rights in Ethnic Minorities

\section{Page 155}

Forum - Challenges of Ethnic Diversity in the World of Journalism

\section{Page 160}

Forum - Are the Media Inclusive?

\section{Page 169}

Mukul Devichand - From Social Networks to News

\section{Page 172}

Nelly Valbuena - Talk with / about Women: an Urgent Need

\section{Page 174}

Lara Whyte - Challenges in the Coverage of Reproductive Rights and LGBTI Communities

\section{Page 178}

Forum - Female Leadership in the Media

Versión en español 
Memorias PerDebate17

English

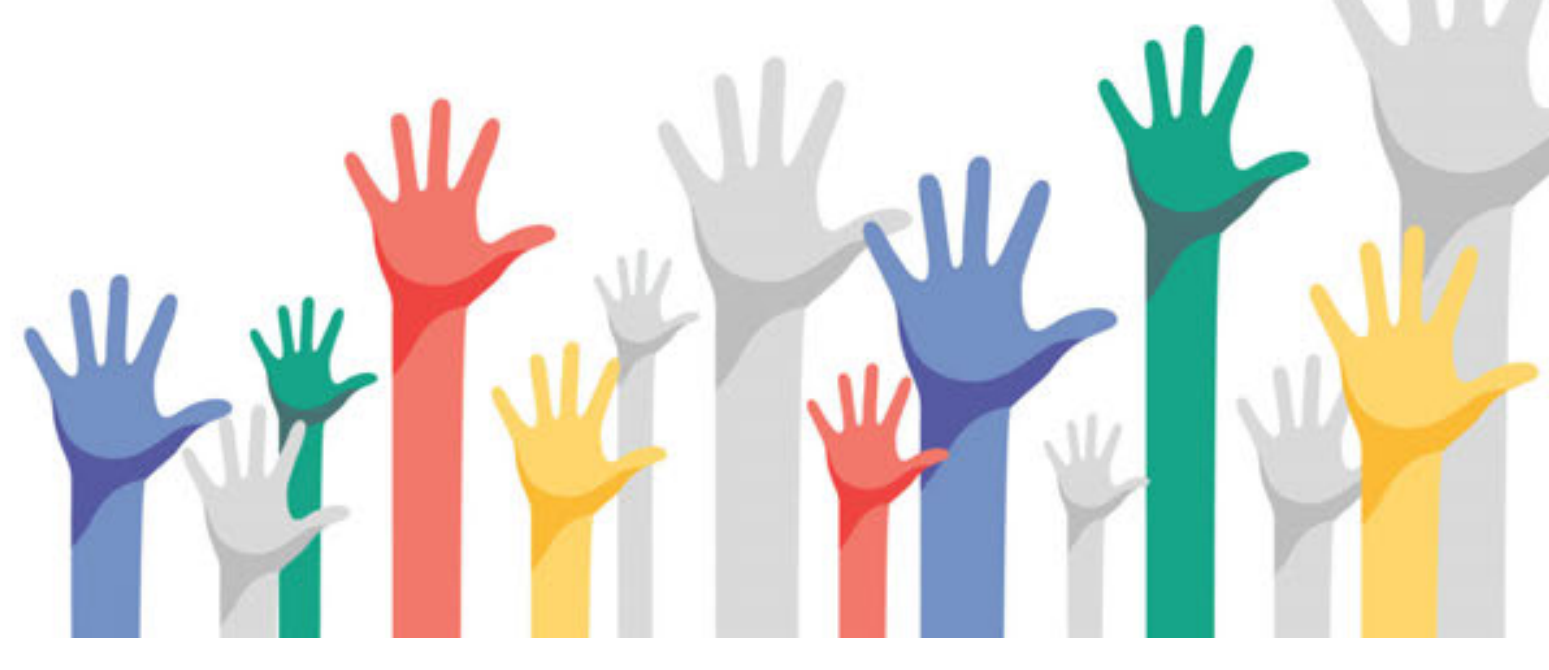




\section{Day 01}

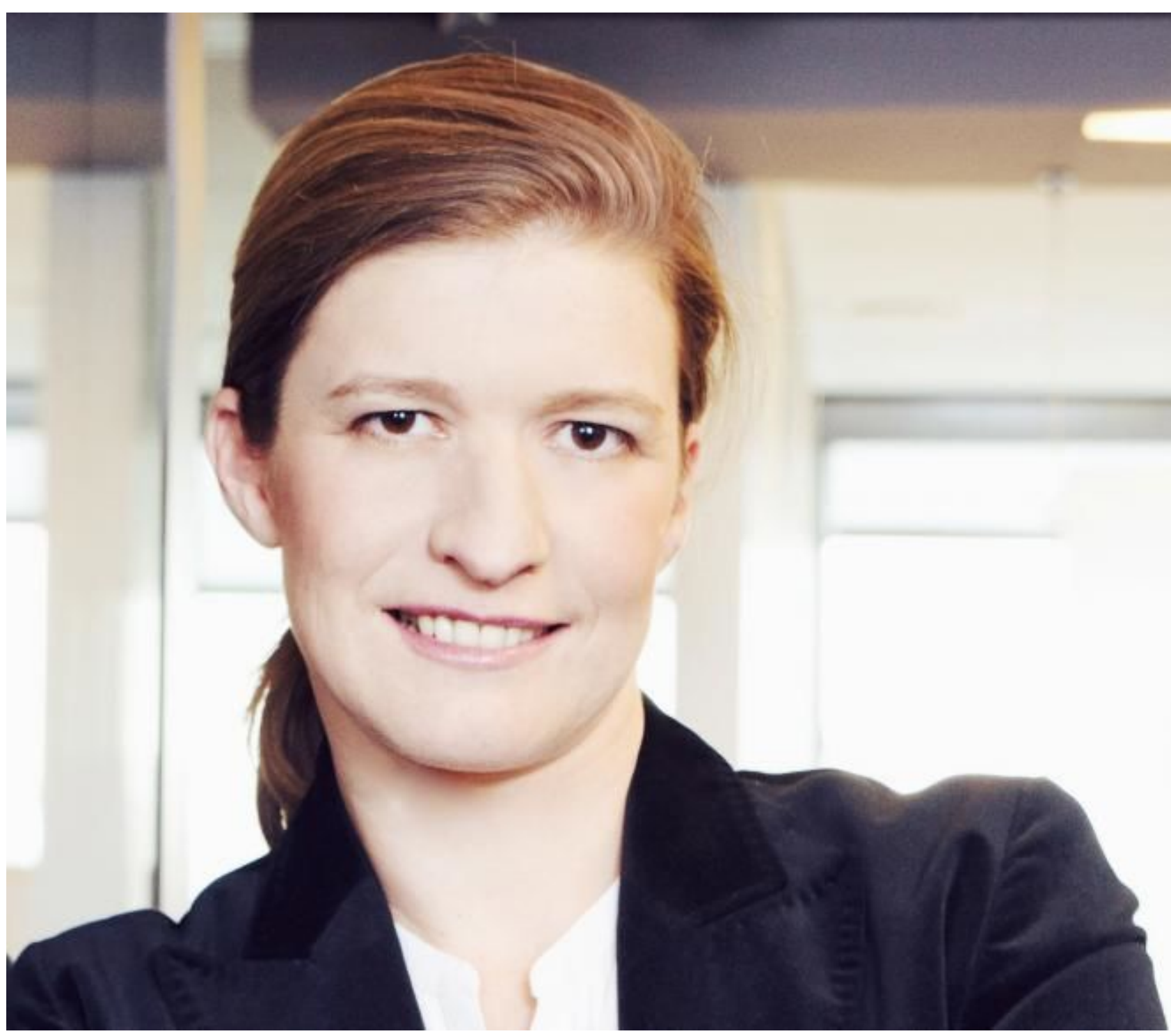


Cécile Mégie,

Director of Radio France International

Back to Index - Versión en español

\section{Keynote Conference: "International Vision for Local Contexts"}

Cécile Mégie, who has been working for five years as General Director of Radio Francia Internacional (RFI), an institution in which she has worked for more than 25 years, thanked the involvement and participation of organizers, embassies, journalists and students., in the realization of the VII edition of the International Congress "Journalism in Debate". Key event and necessary to learn, leaving the routine.

A video of short duration projected the members and the subjects that make Radio France International (RFI) and, the importance of listening to the voices of the world. RFI is made in French, but also works in 13 international languages, recognizing the need to speak with its audiences

\footnotetext{
RFIhas been working in Spanish since 1983. There are 28 radios that broadcast RFI programs in Ecuador and 400 in Latin America.

in their own languages. There are international radio stations, such as the BBC and the Voice of America that work in many other languages in their programs; RFI works with the strategy of creating content in new languages, especially in Africa. Spanish is an important language for RFI, it is a challenge that has been working since 1983; there are 28 radios that broadcast Radio Francia International programs in Ecuador and 400 in Latin America.
}

Radio France International has been broadcasting for more than 70years, maintaining trends and formats, approaching its audiences in Africa, Haiti or anywhere in the world. 
In the editorial line of RFI, the information must be reliable, verified, responsible and balanced. RFI believes in the importance of fact checking so that audiences can trust the information that is said. An example of this was a French-speaking country that had a news program with incorrect, unverified information; RFI and other radios controlled their information. The work of the correspondent is to verify the information that is delivered to the public, to separate the rumors and to focus on the true information. And that is something vital in RFI, which has more than 156 FM radios in 59 countries with which it has an important level of responsibility. In addition, it broadcasts in satellite cable and in 579 radios in Latin America and the Caribbean, and more than a thousand in the world; in social networks, 4 million followers on Twitter and 15 million on Facebook. RFI has an audience, in FM, amounts to 40 million. employees who sometimes work in difficult situations such as in Mexico, Africa or Syria, where journalists put their lives at risk. He affirms that in the life of a journalist there will always be risks, not only in the work areas, but in their daily lives it is important to have security policies in which the correspondents can feel safe while doing their work. These last 15 years, RFI had four workers killed while doing their job. One in Afghanistan, one in Côte d'lvoire and two whose death is memorized every second of November as the International Day Against Impunity Against Journalists.

In RFI there is a trained person to follow the security procedures and every time a risky situation arises, this person helps the journalist because, he adds, there is no story that is worth the life of a journalist Immediately, extensive tracking is performed

\section{In Paris there are 450 journalists and around the world over 400 correspondents specialized in various languages}

when a correspondent is in a dangerous place

Mégie highlights the vitality of RFI as a large radio with a large number of members. In Paris, for example, there are 450 journalists and around the world more than 400 correspondents specialized in several languages. The objective of RFI is to be close to the audience at a thematic level, going to the field and working with the native language. It is the correspondents who must feed the radio and be able to explain the news circulating in a country miles away from France. The basic objective of a correspondent radio like RFI is world is interested in different countries and finds people in France asking about the situation of South América.

Another important issue for Cécile Mégie is her responsibility as Director General of the radio where extreme security measures for all outside of connections and contacts. It is a highly organized team that accompanies the correspondent. There are journalists who question the assurances given, but for Radio France International it is necessary that the correspondent can work safely with less risk.

Mégie pointed out the issue of the media and the impact they have on society. Most of the 400 journalists working in Paris started with the idea of working in a radio, so for them this transition to new formats is a challenge. Social networks, community management and new gadgets are examples of what RFI is working on now. Data journalism is also very important to adapt to new formats and capture the public's attention. 
Journalists are prepared to be able to publish reports, audios, interviews and videos on various platforms. In addition, as the proximity between the radio and the public is so important, the journalist is prepared to work in different languages. In Africa and Romania, the radio has done different works to create proximity not only in the language, but in the news. Also in Cambodia, where every day there are more problems of freedom of expression in the media, RFI has been working there with other radios. Same as Haiti, which is the second most important French-speaking country for RFI.

Radio France International is a public medium and receives money from the state. Money has been used to develop programs in different languages. One of the key elements to maintain government independence is that RFI receives money from people's taxes, so RFI does not owe the government but the French who pay that tax. RFI is a public medium; it is not a state media that is the voice of the government that passes. In the 1950s, several governments tried to control the agenda of public media, but RFI always maintained its independence. Mégie added that the issue of demonstrations against the Labor Law in France can be a difficult subject to explain in different countries. It is also difficult to clarify that the fact that RFI is a public medium does not make the voice of governments, can criticize it as it does today with the demonstrations.

Radio France International is a public medium and receives money from the state. Money has been used to develop programs in different languages. One of the key elements to maintain government independence is that RFI receives money from people's taxes, so RFI does not owe the government but the French who pay that tax. RFI is a public medium; it is not a state media that is the voice of the government that passes. In the 1950s, several governments tried to control the agenda of public media, but RFI always maintained its independence. Mégie added that the issue of demonstrations against the Labor Law in
France can be a difficult subject to explain in different countries. It is also difficult to clarify that the fact that RFI is a public medium does not make the voice of governments, can criticize it as it does today with the demonstrations.

In countries such as China, it is considered that the radio must be aligned with the government, the same happens in some countries in Africa where the emission of RFI has been cut off from the air for nine months. Therefore, it is vital for RFI to maintain its independence.

Ahmed Abba, an RFI journalist, two years and three months ago is in a prison in Cameroon and his fate will be decided on November 16, his trial has been canceled. He has been sentenced to 10 years in prison, it is also considered a death sentence. His sentence was pronounced in a region where Boko Haram is present, Abba contacted members of this terrorist group and is now accused of complicity with this Islamic movement in Africa. His work has interviews with members of Boko Haram and is part of a journalistic work, make contacts and talk with people, so this should not be seen as proof of complicity. RFI defends this journalist for more than 2 years to make people understand that contacting and talking with sources should not be punished by law.

Mégie concluded his conference by underlining the importance of correspondents and how they are the only ones who always have the truth, their editors should always support that. In addition, the correspondent has to know how to choose the stories that are told on the radio because there may be very local events in some countries that do not have international significance. In times of crisis, the role of RFI is to ensure that the journalist keeps distance and is safe.

RFI has been rated first or third in audience in seven countries. Many governments listen to what is said in RFl; responsibility of the 
correspondent is to make sure that the sources and information are true. Especially in times of crisis where governments are listening and the correspondent has to be sure. An example is Jean Helene, an RFI journalist, killed in Cote d'Ivoire in a pre-war state, it was believed that Helene aligned herself with France's position during the war and that is why she died.

Self-censorship has been necessary in RFI in order to ensure the integrity of the correspondent and the people involved. That is, regulate the need to make certain information public, which could generate violence because of the situation. The responsibility of both the correspondent and the editor is enormous at the time of the creation of content and news to be reported in RFI.

\#PerDebate17

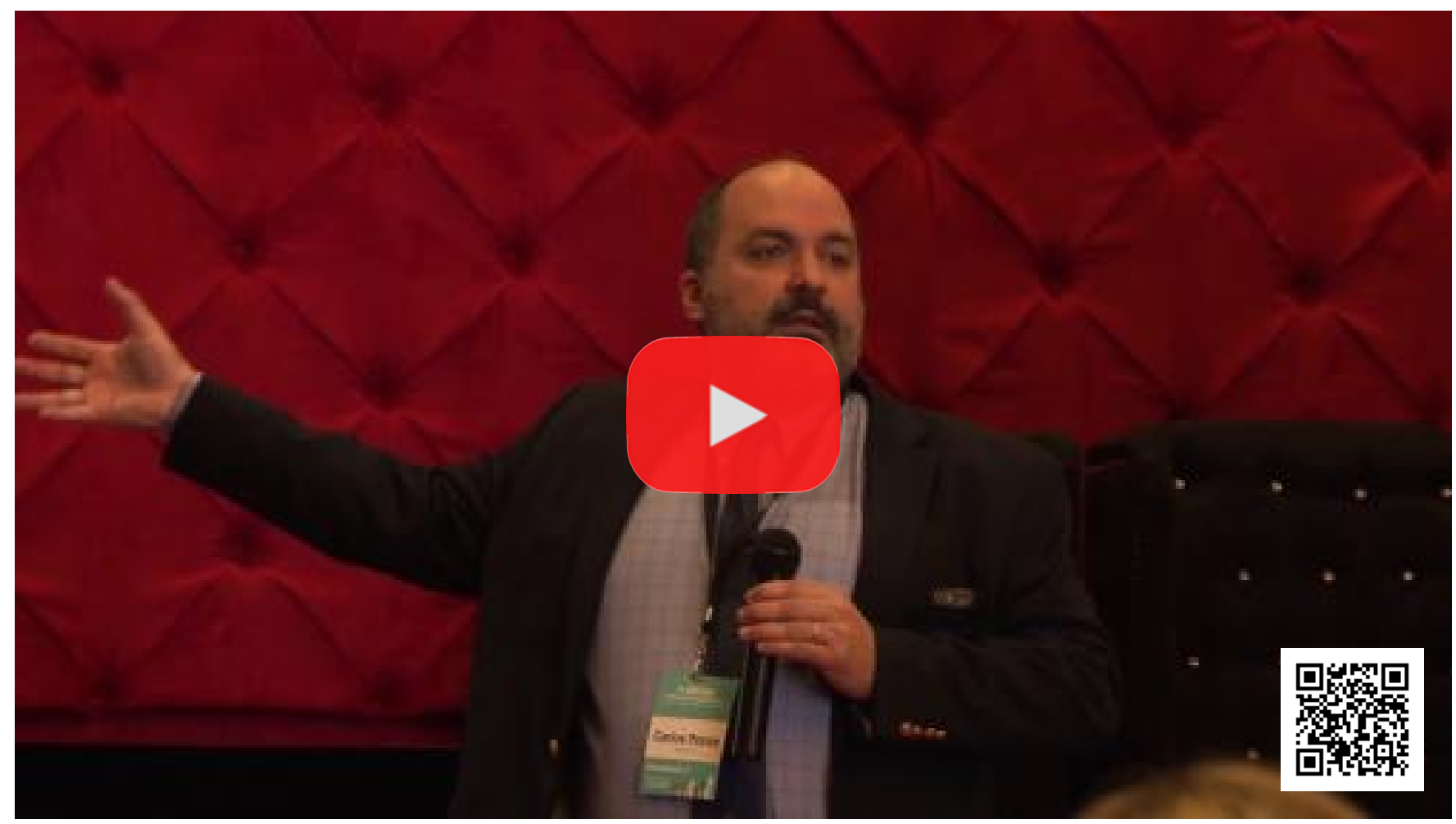




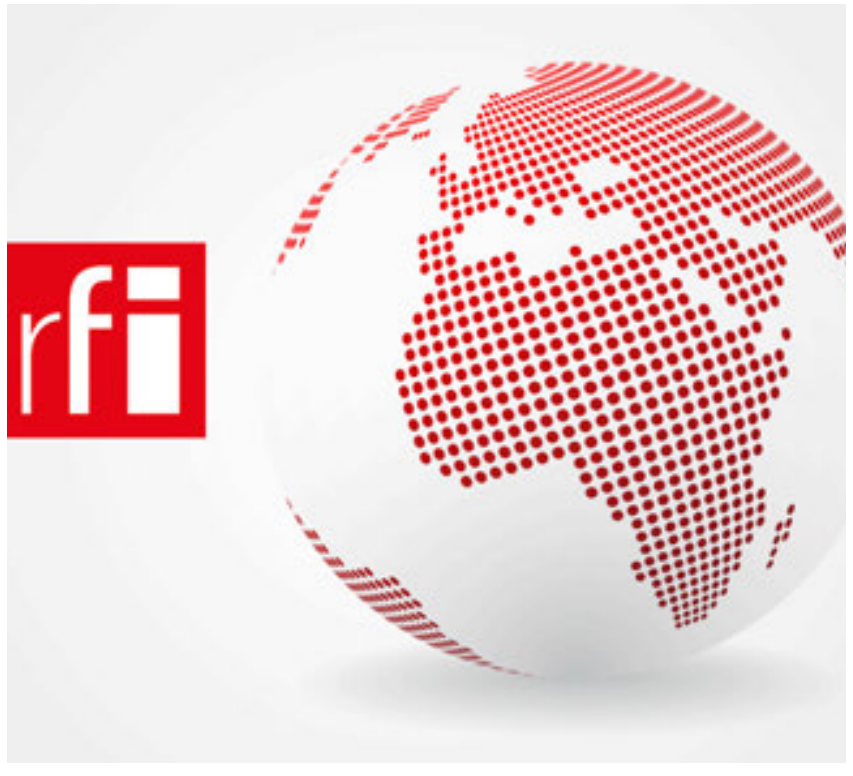

International Audience

RFI is made in French but

it also works in 13 international languages as it recognizes the importance of talking to their audiences in their own languages.

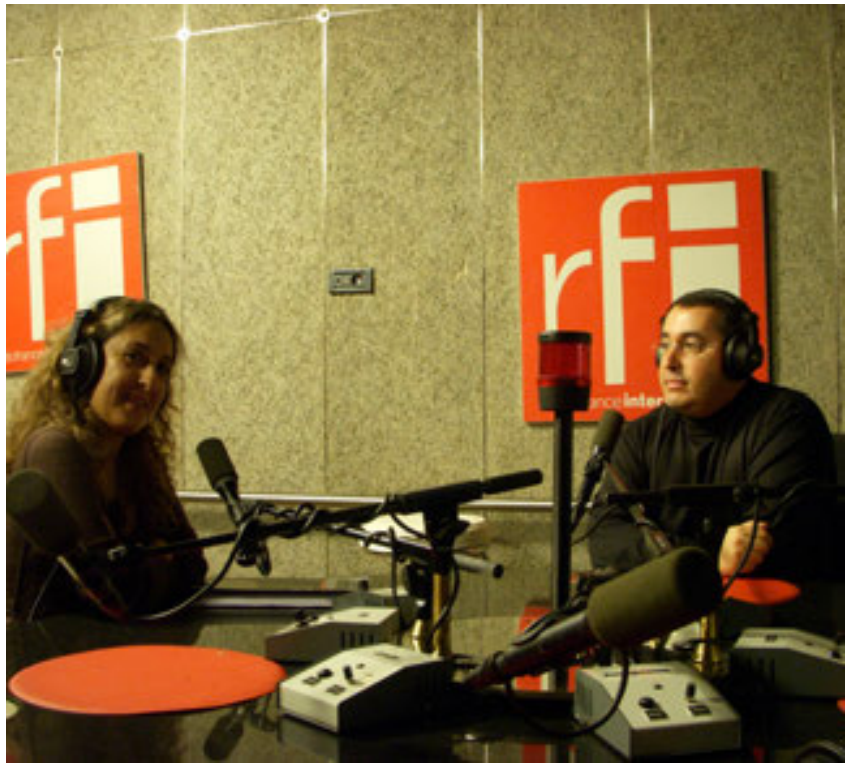

Journalists Challenges

In the last three years, $60 \%$ of the searches are not done on the web page but on the social media. Most of the 400 journalist that work in Paris started with the idea of working on a radio, so for them it's achallenge this transitionintonew formats. 


\section{Susana Morán,}

Conference: Powerful Girls Ecuador

Back to Index - Versión en español

\section{"A Digital Community led by Women in Latin America”}

Susana Morán, journalist in charge of the conference, thanked the opportunity to participate in this debate, an important space to reflect and talk about journalism in Ecuador.

The Chicas Poderosas initiative began working in Ecuador a few months ago. This was launched in September 2017, it was thought that it was vital to take this initiative to Ecuador, as it was one of the few countries that did not have ambassadors of the Chicas Poderosas. Morán clarified three basic ideas of what this initiative represents.

First, it is an international non-profit women's community in 13 countries and Ecuador is one of the four countries with this initiative, especially journalists from the region with the aim of promoting new digital media as an opportunity to do good journalism. With the help of these new narratives in journalism, factors are generated to further develop and improve their content. They started in 2013 with Mariana Santos, the founder, graphic designer, who has worked on several other projects telling stories of international and local events. In 2010 and 2011 he began to work on the innovation of a newspaper. It was a group of about 180 people when he realized that there were only three women. It is there when you ask what is happening, why women are out of the conversation of this world of technology. Since then he has been doing many things, one of them found Las Chicas Poderosas, a movement that has been growing in many countries.

Second, the Chicas Poderosas initiative has a gender perspective, it wants women to get involved in technology in their daily lives and in their work. This community is very inclusive and anyone interested in being a part is welcome. They are diverse, not only there are journalists, the community is formed by designers, communicators,

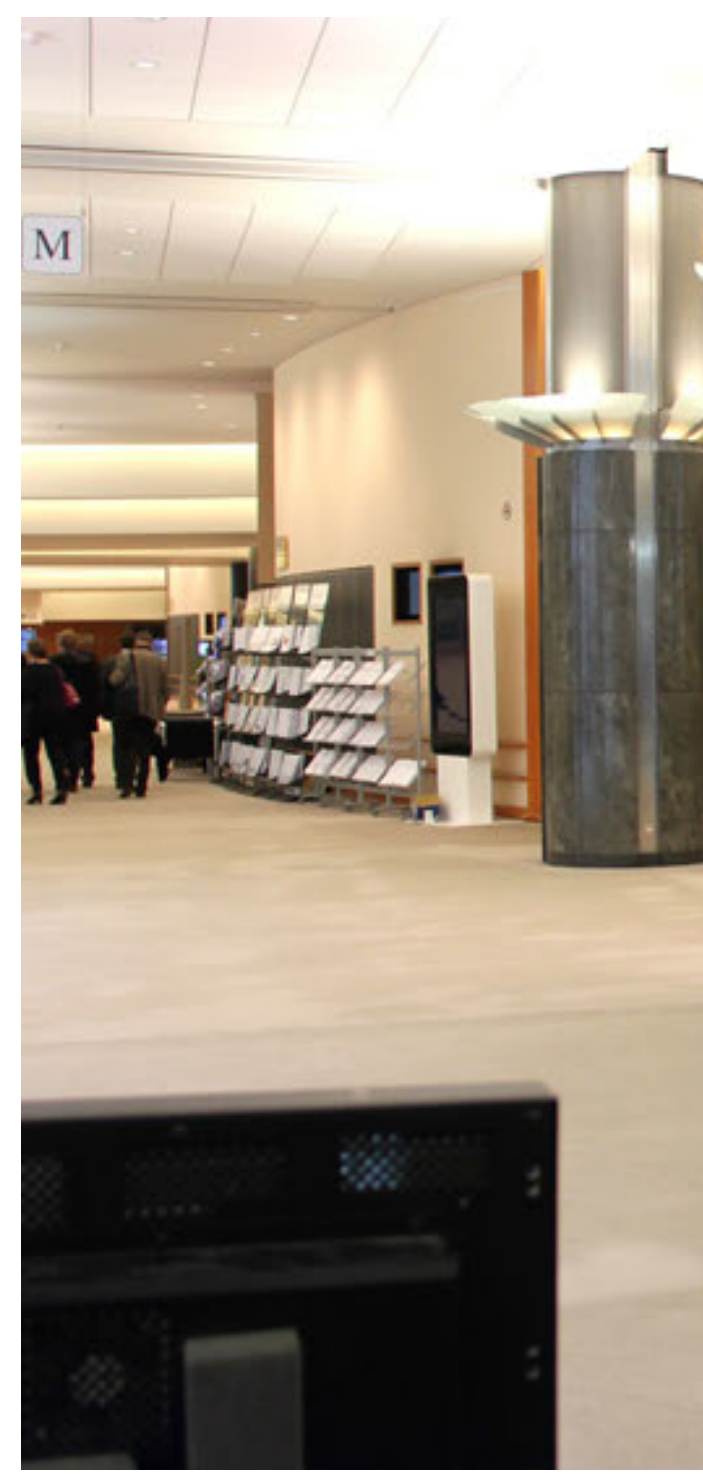




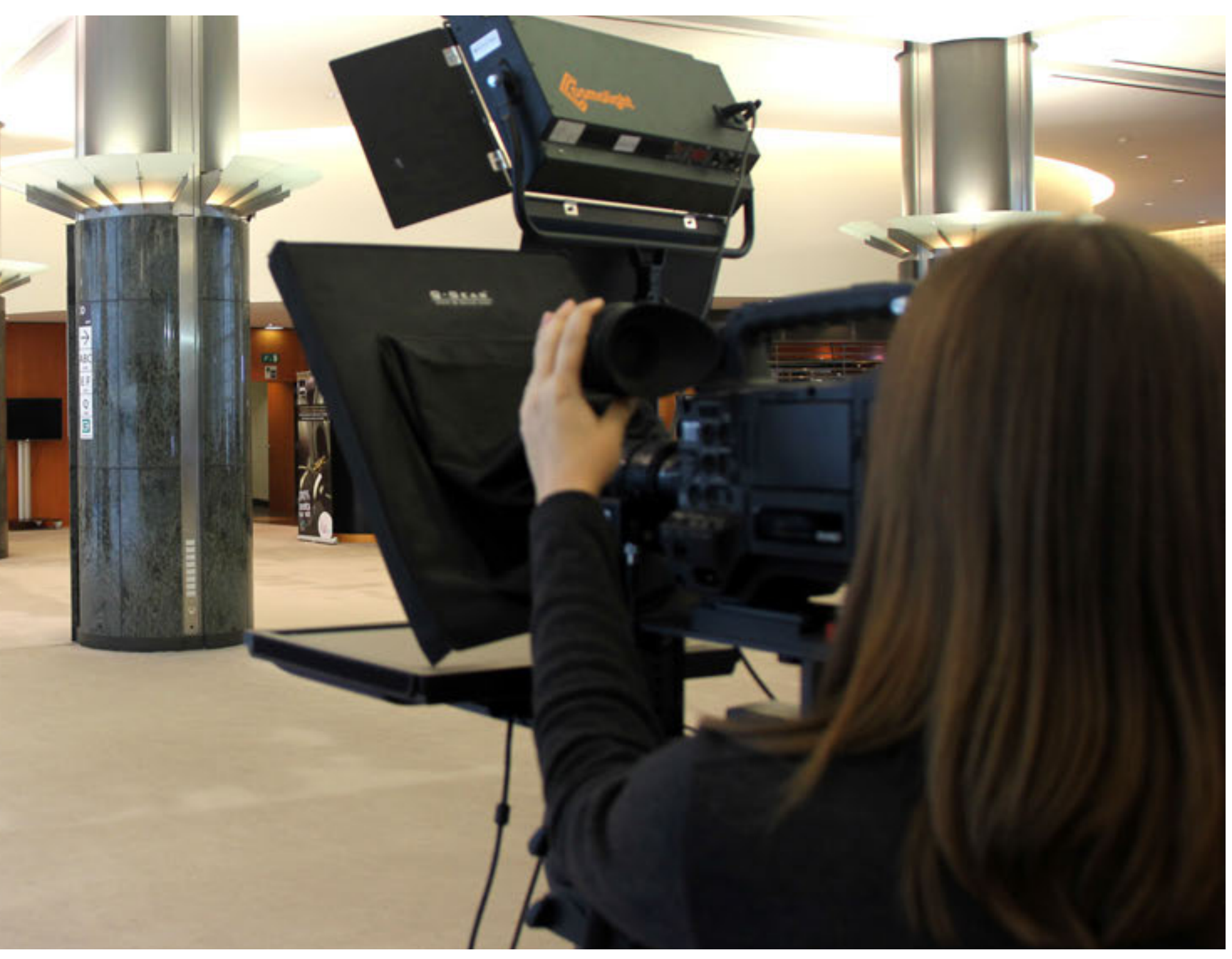


architects, musicians, artists, mathematicians, economists, professionals who want to tell stories that matter. And this is exactly what this community is looking for, working with different people in order to seek innovation, as Mariana says, crazy and exceptional things for our countries.

Third, Chicas Poderosas works specifically on two main issues. The creation of debate in order to reflect on the role of the journalist and what has been done to improve it by giving workshops and lectures for the community involved. Talk about experiences and try to have the best talent in the best places in order to create projects and new things.

At the launch of the Chicas Poderosasinitiative in Ecuador, women who are leading different projects were invited. One of them Carolina Mela who works in the investigation of virtual reality in Spain. She spoke about her experience in new technologies and her work, and how Ecuador still needs workplaces to develop these new narratives with journalism. Chicas Poderosas decided to start workshops to talk about virtual reality as a way to tell stories about sexual and reproductive rights. These new forms of journalism using new technology tools are the basis of Chicas Poderosas.

Susana Morán presented three important projects that are being carried out in Latin America. Projects that have grown with synergy knowing the exact people at the exact moment. That is the spirit of Chicas Poderosas to create these projects to improve journalism and talk about the problems that affect women and of which no one else speaks, such as gender violence.

On the website, there is an article called "Stories of Femicide". This project began in Mexico with CONNECTAS, a group of journalists who support the research. Together with the Chicas Poderosas initiative in Mexico, they started reading the yellow press and all this information classified it, each attack on a woman became data for them, classified the information by age, location, what type of crime was committed and if the murderers had any relationship with the victim. All this became a huge database that has been internationally recognized. In Ecuador, Critical Geography, a group of female geographers, are developing the same idea in order to have local statistics of femicides. Statistics have been obtained faster than those obtained by government entities in charge of homicides and crimes.

A project was socialized in which Chicas Poderosas are currently working, a media accelerator driven by women. It is something very new in the region, since it started in Brazil in October. The idea of this project is for women to be in leadership positions in journalism. It is a 5-month workshop and will be given every year and no matter the country is the sponsor of the program, you can participate in all countries and in all projects. It has been done with the idea of promoting independent journalism.

Morán finished his lecture with some important statistics of women in the media. SembraMedia carried out an important investigation, led by a woman, where she identified that, in a hundred digital media in four countries of the region, $60 \%$ of them, women were part of new projects and $40 \%$ of those projects were led by women. The Powerful Girls want to develop these same abilities. Next year in Ecuador, they will bring Mariana Santos to tell her experience and strengthen the initiative in Ecuador. Susana Morán invited everyone to be part of this community. 
Carlos Ponce,

Director at Freedom House in Latin America

Back to Index - Versión en español

\section{Keynote Conference: "Lights and Shadows of the Real Situation of Press Freedom in Latin America and the World"}

Freedom House is an organization that for more than 75 years has promoted different freedoms, human rights, freedom of the press, association, expression and religious freedom. This organization was created by a group of people with Eleanor Roosevelt for the United Nations to prevent the misfortunes that occurred in the last century, maintaining freedom and respect. Thus, the organization was created to promote the universal declaration and later to become a center of exchange of ideas to materialize democracy in different regions and promote a series of strategies that can lead to greater freedom.

Ponce, regional director of Latin America and the Caribbean for the programs of Freedom House, explained

\section{Freedom House it an organization that for over 75 years has promoted different freedoms like human rights, freedom of press, etc.}

that the structure of the organization is hybrid, unlike other human rights organizations. Freedom of the Press has other roles. First, he works directly with associations of journalists in Venezuela or Cuba, in countries with a very closed society such as Iran, Zimbabwe or vulnerable groups in different countries such as Mexico, Guatemala, Honduras, ElSalvador or death squads. from Nicaragua, Paraguay, Ecuador, Venezuela and Colombia. The other part is the impact with the congress in the United States, the OAS and other countries to promote interesting changes and in press. On the other hand, it works with protection funds for journalist at risk, protection and security is given to defend journalists through direct assistance, as well as for LGBTIQ groups or religious groups. In addition, Freedom of 
of Expression works giving reports known as Freedom of Expression, Freedom of the Network, Freedom in the World that is published every year.

Organizations have classifications and qualifications; their Freedom in the World report is 50 years old and is the oldest category to measure the State and democracy worldwide. Freedom of the Press is 38 years old and in spite of other older rankings, it is well known and used mainly. Freedom on the Net is 5 years old. Many people ask the use of these qualifications. Most of the time, authoritarian governments worry about what people think and, on the other hand, most of our rankings, at least the Freedom of the World and Press Freedom, are used by risk rating agencies to assess the ability of a country to cooperate. Millennium funds from the United States usually request Freedom of the Press for their classification to decide whether or not they want to give resources to a country. When the World Bank decides to grant a loan, the decision is based on their rankings.

Therefore, the classification has an impact. For example, when you mark the region of Mexico, Venezuela, Nicaragua, Cuba as non-free countries, generates an impact. But it also has an impact on the work of many journalists and bloggers, since they realized that they are living a percussion that is being shown by someone outside the country, that is to say that it is of international attention to know what is happening with a tortured journalist or disappeared, in different countries. Sometimes the percussion of the journalist is more expensive because in the end the credits that the country looks for are more expensive.

It is a report that has the collaboration of national experts to make a global rating. In the presentation, Ponce showed that there were few countries, but also said Freedom of the Press is not the only one, since Human Rights Watch or Reporters without Borders have done the same. Anyway, the interesting part of all these organizations is that they have arrived at the same problem in countries without freedom. Like the same conclusion that Mexico is a country at risk for journalists and bloggers, civil society, with justice being the tool of persecution. Ponce showed the similarity in Zimbabwe, North Korea, similar reports and authoritarianism as a model of government, violating freedom rights.

Freedom of the Press also analyzes authoritarianism and the challenges that countries have when they lose their freedom. An interesting idea is that the more authoritarian the country, the more the government has had to persecute journalists who seek the truth. Nobody wants a journalist to investigate human rights violations, nobody wants a blogger to report disappearances or corruption. Journalism is persecuted in most countries, even in the United States, a supposedly safe country for journalists. All the countries where the government has persecuted journalists try to limit freedom of expression, they try to control all means; The same behavior can be seen in the governments of Latin America where governments have decided to take possession of the media directly. Venezuela with Hugo Chávez, Nicaragua with Daniel Ortega, Rafael Correa in Ecuador. Controlling journalism, controlling the means to self-censor them is a way to control expression in countries.

Ponce explained that in some historical moments there are several comparable moments within the time in which the variety of freedom can be seen. In 1996, many countries wanted to live in democracy, after the breakup of the USSR. In Latin America, more governments were left out of military control. In the previous years, 1986, much control had been exercised over freedom and the press. Since 2006 and 2016 we can see that freedom is being reduced again, there is more persecution and more harassment. From 38\% of the free countries it was reduced to $31 \%$, meaning that most of the countries have gone to the state of partial freedom. Another key fact was the freedom of the press in Latin 
America and it was demonstrated that Costa Rica is the country with the highest freedom indexes, followed by Uruguay, Chile, El Salvador, the Dominican Republic, Peru, Argentina and Brazil. In contrast, the worst countries in the region are Cuba, Venezuela, Ecuador, Honduras and Mexico. The rating can be more segmented and show the categories in which countries qualify. For example, in Mexico it is possible to qualify press freedom, the number of murders of journalists not only by government entities but also by companies. Also in Honduras, where being a journalist is a big risk. And until 2016, being a journalist in Ecuador was also a risk; the persecution, the laws, the control, are some factors of the classification. In addition, Venezuela with the closure of international and local media as well as blogs and Twitter, Cuba without freedom at all.

¿What are the challenges for press freedom? First, if there is impunity in a country, even if problem is that it becomes a great judgment that prevents work, which is what governments want.

Ponce disclosed more ratings found on the website, police intimidation, and purchase of media by governments or frontmen, restriction to the source of information, even in the United States. The use of the press, social networks, trolls to discredit journalistic work and control what or what not to publish. Another important category is the spying of journalists that has begun to increase in more countries, how the government spies on a journalist and uses his private information to censor. For example, the censorship of social and academic media in China, which has made Cambridge University Press not publish what is considered to speak ill of the country. Ponce had the opportunity to speak with the American actor Richard Gere, he said that for him it was impossible to be in a commercial

\section{Freedom House found is that the more authoritarian the country is the more need it has been for the government to persecute journalists}

some entities modify it, if the justice system does not investigate threats, corruption and denunciation of journalists, impunity will be a real problem, since it is one of the main limitations in the exercise of democracy. In all countries, we see that less freedom plus regulatory centers have been created for the control of the media, to punish journalists, persecuting and creating an atmosphere of limitation. Use of the justice mechanism to persecute journalists as threats and judgments. Ponce believes that good journalists get used to lawsuits, lawsuits and threats. He, for example, is not welcome in Venezuela, Nicaragua and Cuba. The interesting thing about this is that a lawsuit in Nicaragua does not matter; now Nicaragua demanded it in Washington, to start persecuting it internationally. And the film due to the blockade that China gave him for his work in Tibet. In the episode of House of Cards, American series of web television, where mention was made of China, it was only broadcast once and had to be modified. It not only pursues opinion at the local level, but pursues worldwide opinion.

A large number of governments excuse themselves arguing that they are protecting journalists, but this type of mechanism only promotes corruption. As Freedom House, protection programs must be created, such as in Mexico or Brazil. These systems were good, but then they realized that the journalist is alone in this battle, because the mechanism created only projects a good image of the governments, but if they are not truly fighting 
against impunity, there is nothing to avoid insecurity. The moment to protect the journalist is the moment when they begin to be threatened or the moment when freedom leaves that country. It does not matter if all security exists, if there is impunity, as in Malta, a bomb kills a journalist who had been looking for corruption in governments.

This year, Libertad de Prensa also published La libertad de la Red in order to study trolls, repressive media with bloggers, and how they prevent people from using the Internet. They simply do not allow the blogger to work freely; governments are developinglaws supposedly to control decency in social networks that are simply done to allow people to freely use the Internet. False information and verification of information, all are on the Internet and governments are excused controlling providers to clean up all false information while controlling our right to use the Internet.

The main challenges in Latin America, as explained by Ponce, are net neutrality. Governments see as a threat for people to have full access to the network, the result is that large companies are working with governments to limit freedom of expression.

Ponce invited to visit the website and see the rankings. He thinks that this is an endless job because as an authoritarian government leaves the place, another is being fortified in other countries. It is difficult to see improvements, but it is important to keep working. If it were not for the journalists, the blogger, the journalists who work against corruption, the Panama Papers, Odebrecht, everything would be impossible to discover because of the corruption in the governments. Journalists have created maps and a global network to defend freedom. Therefore, the last message is that even when there are difficulties in the journalistic work, be it due to the challenges and limitations, it is worth risking and taking on those challenges. 


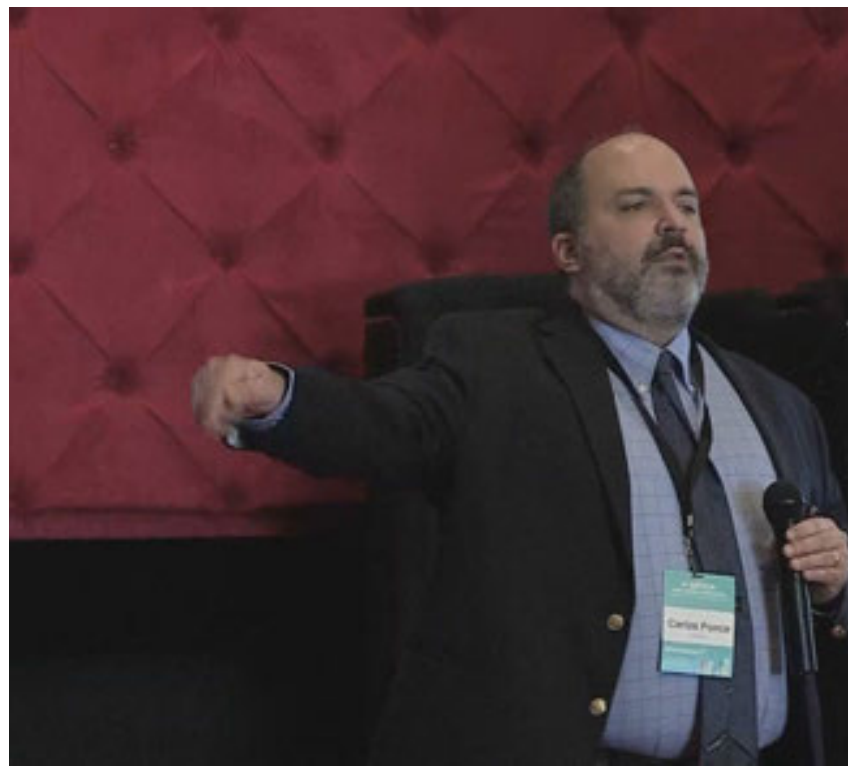

Carlos Ponce

Director at Freedom House in Latin America at his conference in PerDebate17.

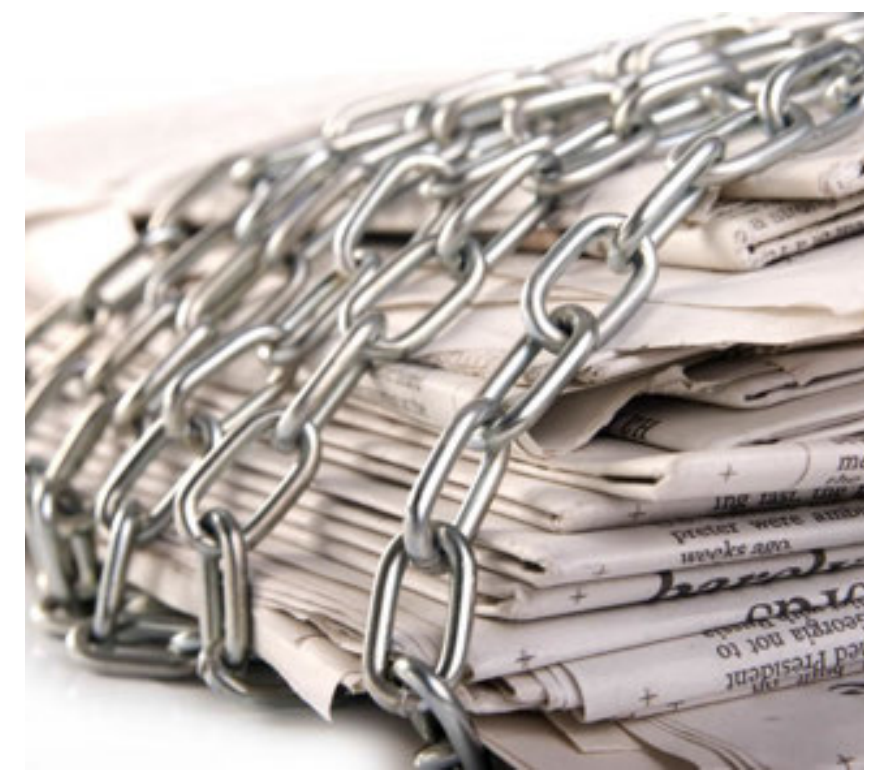

Freedom House

Conducts research and promotes democracy, political freedom and human rights. It is described as "a clear voice for democracy and freedom for the world". 
Tom Sanderson (UK),

Center for Journalism Research (CIJ)

Back to Index - Versión en español

\section{Keynote Conference: "Research Capabilities for Journalists Working in Local Communities"}

Tom Sanderson, representative of the Research Center in London. CIJ is an educational charity that teaches practical investigative skills to journalists; during the last 5 or 6 years he has also taught unions, activists and lawyers.

You have to understand journalistic practice as a call to serve; journalism as a public service without government control and regulation, but more about people, a conflicting example of this, Ecuador and the amendments to communications, December, 2015. Sanderson explains that the public is never a group of people clearly defined and the interest of the public may differ widely. However, the public interest does serve a benchmark as such.

In the UK there is a legal definition of public interest "that includes, protecting public health and safety and preventing the public from being deceived by a statement from an organization or individual, but even that definition is not definitive, in fact, David Lee, an important research journalist and long-term friend of the CJI, adds that " information is of public interest so that the proper function of a democracy ceases." This definition can enter into debate when it is asked what democracy is and how we can say if it works correctly, this debate to get to the answer, the question about what is the public interest.

But, what about journalism, what do we really mean when we use the term journalism? Then, in the classic quotes of George Orwell, "journalism is printing what someone else does not want to print, everything else is public relations", but that's a pretty restrictive definition It excludes another feature of human interest history such as travel writing that many people will see as journalism.

Beyond the resources of time, the importance of investigative journalism is nourished by it independence.

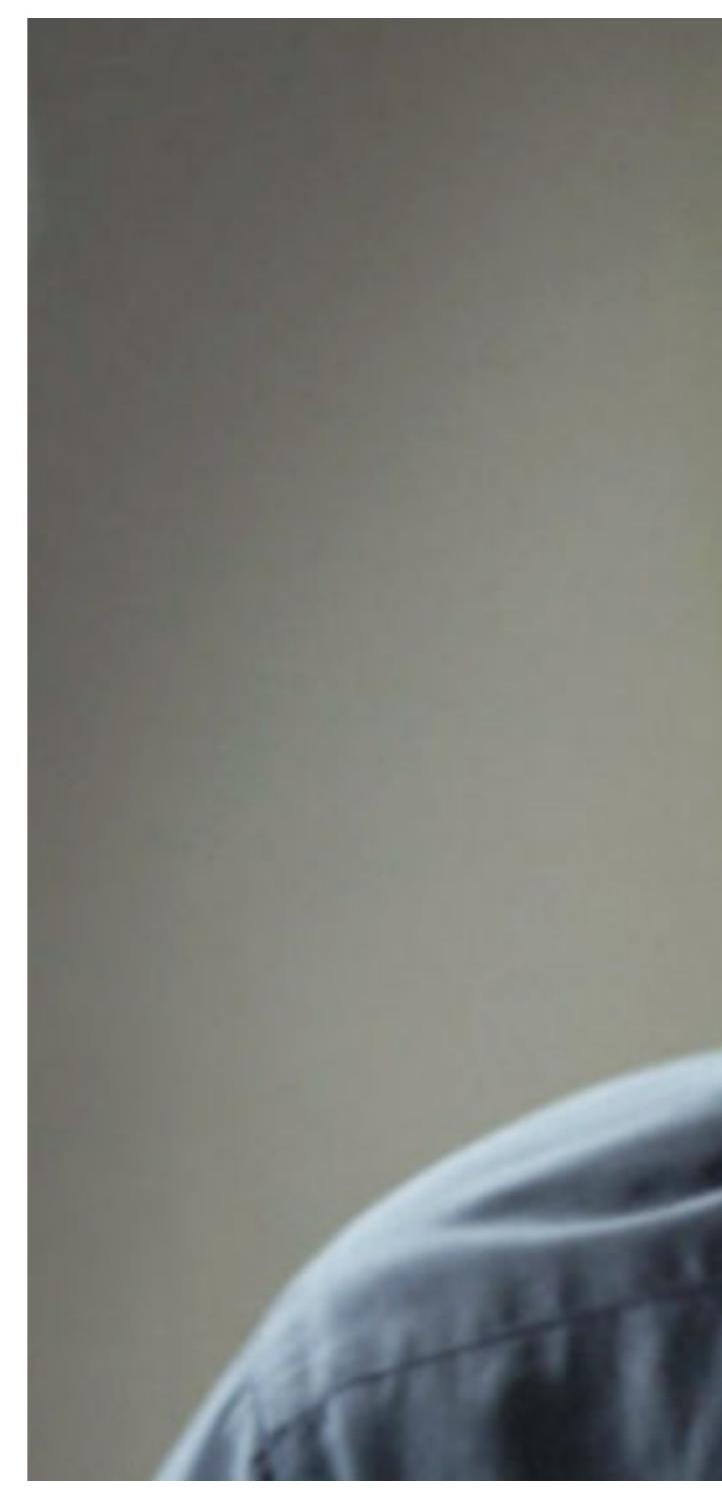




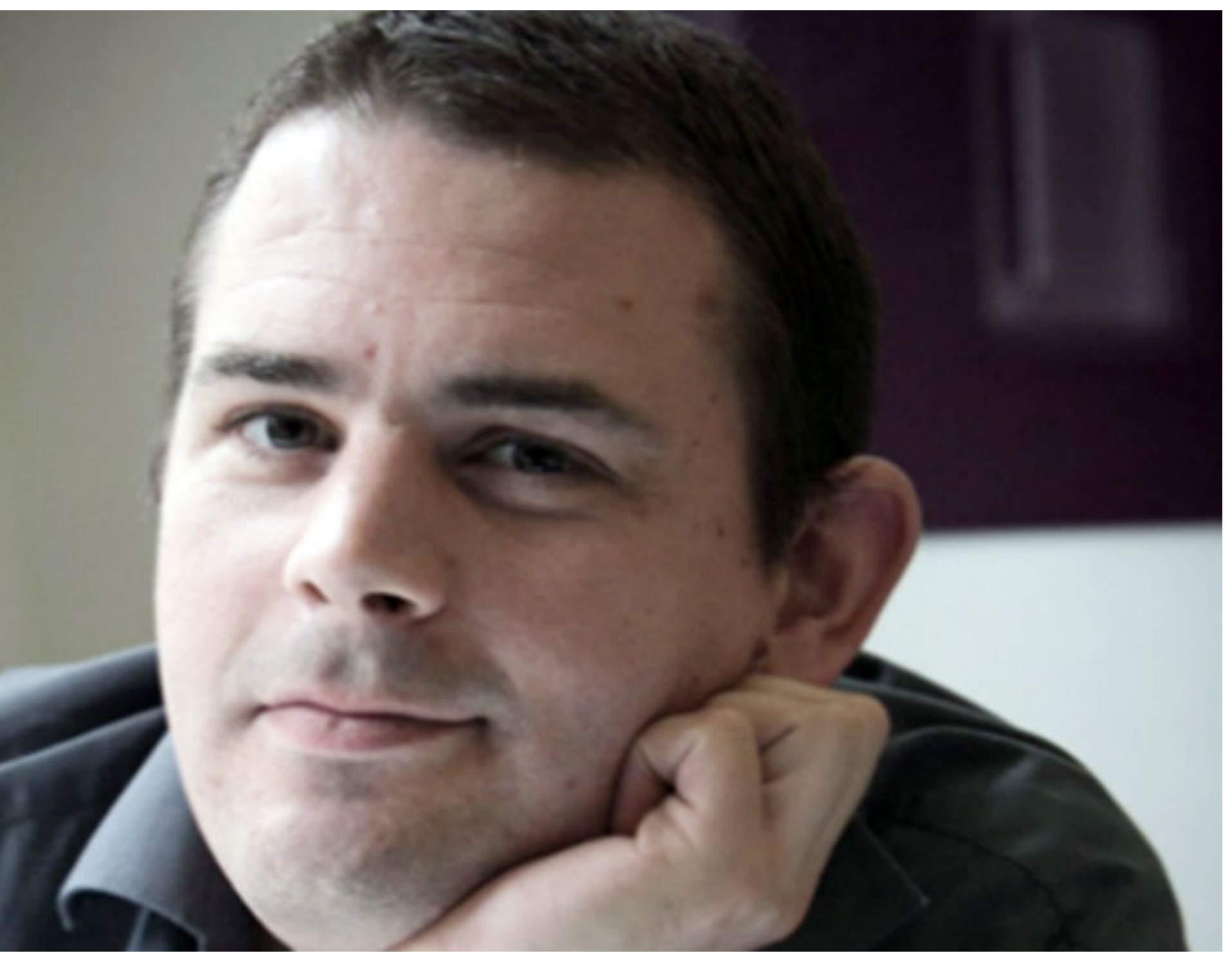


Without independence you will not print what others do not want you to print and without that, according to Orwell at least, you will be doing public relations. But what do we men do when we say independence? The main definition is a question that must be asked.

Then, there are different types of independence, correspondingly, the actors that journalists need to ensure and ensure their independence. Then, political independence, government, editorial independence and financial independence form advertisers and owners; that develops in different ways, in different contexts, Sanderson explained some examples to understand how some of these interests have compromised journalists and organizations.

First, in February 2015, Peter Oborne, the main political commentator for The Telegraph newspaper, resigned publicly. Oborne was concerned about the independence of the document throughout a general who declined quality and values. He had already agreed to resign, but was going to go quietly at the end of his contract. His decision to make his reasons for his resignation public was due to The Telegraph's coverage package for the investigation of ICIG files.

This investigation showed that a bank recognized in England manipulated some financial markets and complicity in tax evasion. All international newspapers publish that story on the front page, but The Telegraph, publicized by this bank, talks very little about it. Oborne himself said: "You need a microscope to find The Telegraphs coverage." Oborne continued, "If major newspapers allow corporations to interfere with our content and fear losing publicity, democracy itself is in danger." So that is an example of corporate interest, which exercises interest in documents, editorial lines.

The following example shows the potential of political interest for the journalist committed to his independence.

In March of this year, George Osborne, who was recently appointed chancellor, that is, the person behind the Prime Minister, resigned. He announced that he would become editor of The Evening Standard, a newspaper read by millions of Londoners.

Therefore, the editorial control of this document has a significant influence on the limits and direction of the public debate. But taking the editorial direction of a London newspaper while still serving as a member of parliament and supposedly working to represent the population in north-west England caused much public disapproval. However, the main problem was the idea that a person with such a clear political affiliation should have influence over an important source of information.

These are some examples of interest of the written press, but what about the local news? If you have any of this problem, enter in this context. During the last decade, the United Kingdom has seen a decline in the meaning of local journalism due to the plurality of ownership and resources that journalists have. We have been to many examples of assets that escape from the really stable local newspapers of one of the five companies that now own more than $50 \%$ of the local press in the United Kingdom.

On the corresponding site, local authorities have spent money on public relations activities. Therefore, the stability of the local press maintains the power account for the decision taken in local communities, has led to increasing pressure from the time of local journalists.

This has reinforced the phenomenon of journalism that Nick Davies identified in his book. Davies says the journalist has little time to verify facts or question official accounts. And we were able to see more and more press articles more likely to be a PR copy-paste. Then, the consequences of this for the proper functioning of a democracy must be clarified. 
But what are the real consequences for local communities? A striking example is the disaster, before this year, of the Grenfell Tower in June, a fire broke out in a house in a block in central London and local authorities neglect the fire safety regulations due to the lack of safety systems. Aspersion, the fire spread rapidly and took the lives of 71 residents.

But what is really tragic is that these problems with this particular block had already been informed by a local campaign group. Therefore, this publication is from November 2016 and highlights the careless oversight organization of that particular block. He even states that "it is something truly frightening that we believe that only a catastrophic event will expose the ineptitude and incompetence of our landlord." Therefore, it was sadly proven that people began to realize but six months later, 71 lives, it was too late. local journalism. In fact, formal local journalists when asked if they would have published Grenfell's article in the 1990s said: "One hundred percent yes, we would have chosen that, if we had found the story before other means, our editor would have told us that We are not doing our job properly. "So, I feel that this clearly shows how the system breaks down in the United Kingdom. In the past, the initial concern was raised by a local journalist who not only covered the community, but was part of that community and this should have continued as a chain that turns the important problem of the community into a national newspaper, and Sanderson explains that this system was perfect or that it will always work that way, but now it seems to work like this worldwide.

It seems that a crucial link has been broken between our communities and the local news

\section{“... there are different types of independance. Therefore, journalists need to ensure their independance, again and again".}

So, ¿what was the answer? The press did note and memorized many fire safety articles in similar blocks across the country. In addition, many journalists began looking for answers and explained how the problem should have been taken seriously before the fire. Then, in a speech in August, a journalist named John Snow said: "The Grenfell episode showed that the media is comfortably with little awareness, contact or connection on the tracks" and said that Britain is not alone in this, thatmany other societies are broken. The main reason why John identifies is the lack of diversity in journalism jobs. $7 \%$ of the UK population has private education, but in the media more than half of the country's leading journalists went to private education at the university.

Tom Sanderson argues that he will argue with John explaining that this is not the only factor. A big factor in his opinion is the decline of meala. But there are some reasons tor nope, there are people to build local news, in a different way, not as trying to capture publicity, but working as a structure to have communities as the heart of the report.

A good example of this is the work of Bristol Cable. A medium that works locally for Bristol but also has national and transnational relevance. They distribute 30 thousand copies in Bristol, but the organization works in a membership base, where people pay and have a say in the decision of the editorial lines and of the store in general. For two years, Cable's membership has been 2,000 people, each donating an average of 2.50 per month, which helps pay for the work of journalists.

Another example of this modern type of news production is The Ferret, a good investigative journalism in Scotland. Its system works in a 

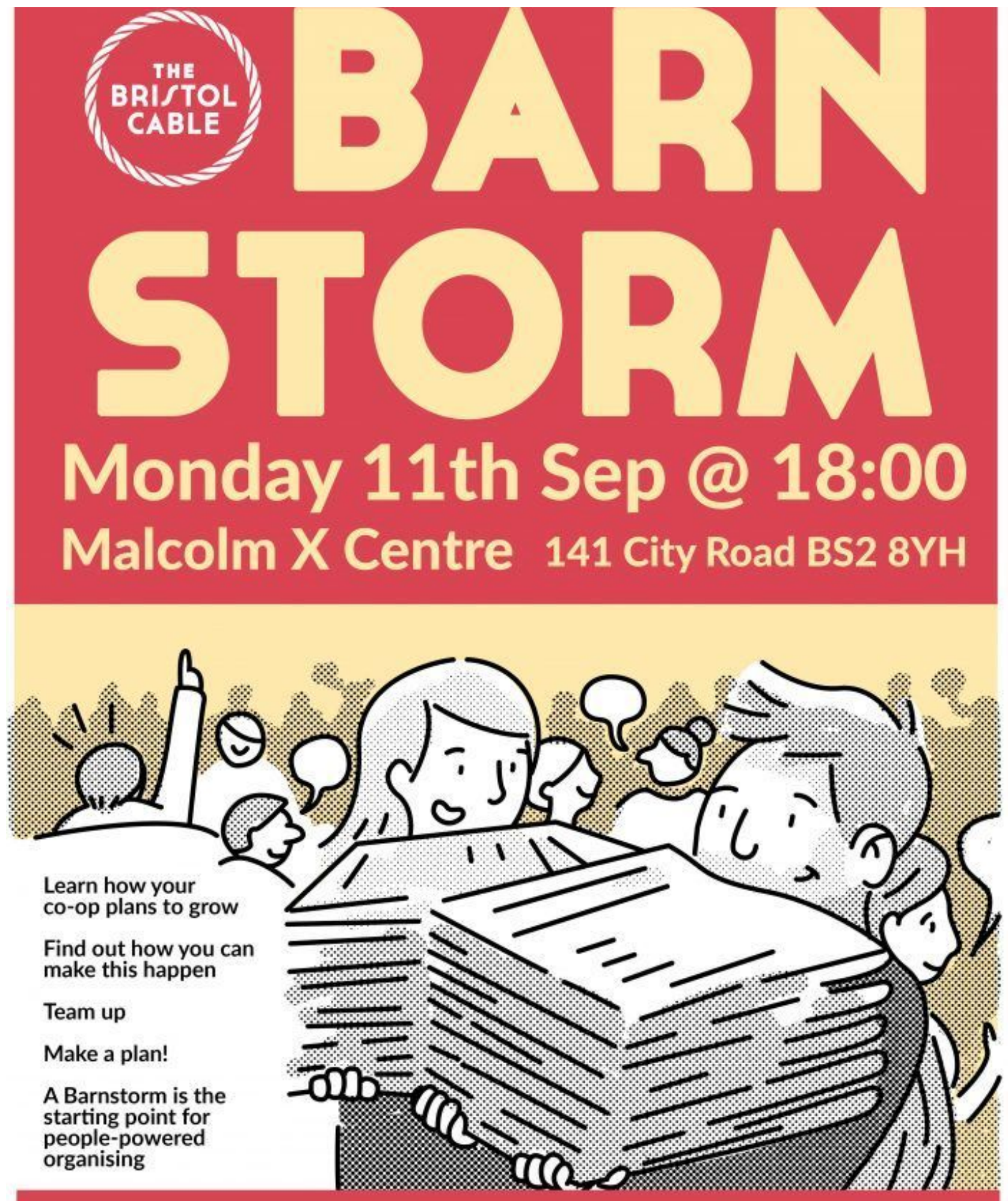

Bristol Cable

A good example of this is the work of Bristol Cable. A medium that works locally for Bristol but also has national and transnational relevance. They distribute 30 thousand copies in Bristol, but the organization works in a membership base, where people pay and have a say in the decision of the editorial lines and of the store in general. 
similar way allowing anyone to subscribe to a donation of a regular month and be part of the meetings and other times if a decision needs to be made. Therefore, both points of sale complement their main income through memberships and events with the aim of being self-sufficient only with donations.

The Ferret has no advertising at all, while the Cable has advertising in its print edition not online. Cable also imposed restrictions on the types of advertising they accept and advertising that is collectively chosen by members. Therefore, both points of sale are a fortune, new models to sustain investigative journalism and keep it free from the influence of individual owners, corporations and advertisers. They are not yet self-sufficient, but the number of owners grows and the situation improves.

In this context, why do people pay these points of sale? Well, the content of the cable is freely accessible, and the Ferret operate free articles per month for non-subscribers, they need other reasons for people to give them money. Therefore, it is partly because the member buys the idea that a medium is interested in their interests. But, in addition, these outlets have other effective strategies to ensure membership, but mainly because their journalism is having a positive impact of these local communities on the way this industry has existed for some years.

Tom Sanderson developed examples of the impact that this local news has had. The Cable reported on the construction of the houses in Bristol. There is a law that establishes that developers should put affordable prices on houses for poor people, but there are always some developers against and argue that their investments are not enough. In this example, Bristol can do a complete investigation of how much money was invested, who invested, etc. Making it clear that the Public of China was investing in this house and how it was possible to break with that type of investors.

The real impact came when the Bristol board decided to always offer developers an affordable standard price for these community homes, as well as transparency in the home industry.

Ferrell, however, conducted an investigation into the extreme right groups in Scotland. Through covert footage they showed that this new group was actually composed of members of a neo-Nazi organization recently banned from continuing with political violence.

The Bristol Cable also researched the finances of the University of Bristol, and showed that much of the money from this university was used to inject gasoline into companies along with other ethically questionable industries. So, that's a good example of public interest information that protected the public from being cheated by an organization's statement.

Tom Sanderson says that here there is a need to help the creation of local news and had identified two main problems: time and money. The Research Center, as an educational charity, can not directly help reduce these problems, but can train these people about research and how to manage their resources more efficiently. They received a fund to finance training in research skills, encourage local communities and teach other courses such as online research, communication law and others. They hope someday to start a network of local communities and news media to replace the property of corporations or advertisers. 


\section{Forum,}

Participants: Juan C. Calderón: Director of Plan V, digital magazine; Tom Sanderson: Journalism Moderator: Paul Mena Mena, Journalist in the newspaper El Universo.

\section{"Investigative Journalism at all Cost"}

Paul Mena Mena: We will talk about research and journalism, I like to start with a question, it is common this appointment that investigative journalism is the guarantee of the existence of a democratic society, but why is it so? Can we land that quote on something more concrete in your experience? How does journalism research guarantee democracy in a society?

Mariana Neira: Why investigative journalism guarantees democracy, is the question. Well, because investigative journalism has a function or a mission to be always alert of what power does, be it political power, economic power, military or religious power. It is necessary to look for the performance of what work these powers are doing. It is important that they have transparency when working so that society feels safe and protected by all governments and organizations. Basically what it does is look at how the resources of society are managed. Resources come from taxes or natural resources. So, that surveillance function is what created this quote that investigative journalism is the guarantee of democracy.

Paul Mena Mena: Juan Carlos, his research has been recognized in Ecuador, especially El Gran Hermano. ¿Can you tell us, please, if you are a guarantee of democracy in our country?

Juan Carlos Calderón: In fact, I believe that investigative journalism is a method that can defend the right to be informed. The only reason, because the journalistic work is to defend the right of the public to be informed of what governments, powers, and society are doing. And that right allows to strengthen democracy. It is not a guarantee of democracy, or we would notbe military, but it is the relevant information that allows that. Now, the investigations carried out by many journalists and talking about this

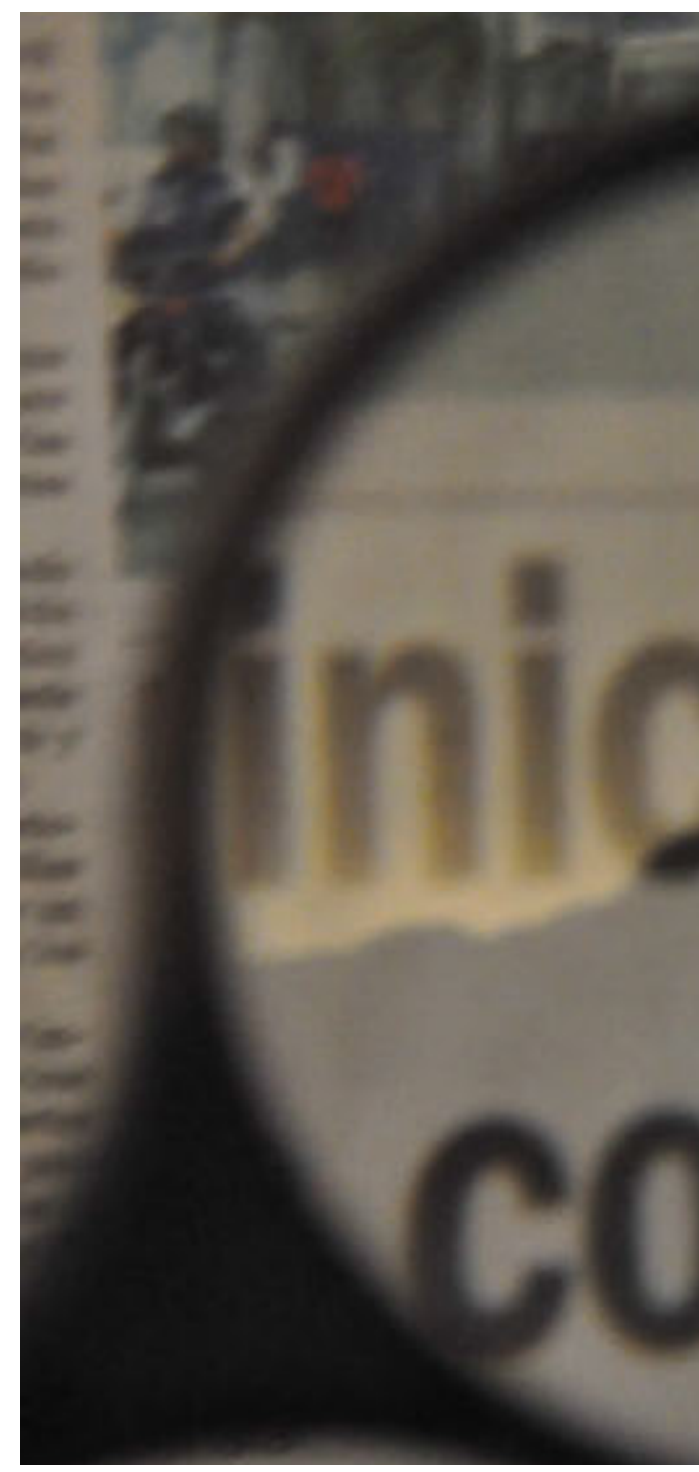


Research Center; Mariana Neira: President of Fundamedios and editor of the magazine Vistazo. Back to Index - Versión en español 
El Gran Hermano investigation that the negotiations of the contracts linked to the brother of the president generate a great impact and without great complications. I think those were one of the articles, which have been made in national journalism in this country, that allowed the public to know what others were trying to hide. Because journalism discovers what is hidden. And in this case, investigative journalism let know something that others were hiding and that was important.

Paul Mena Mena: Tom, in your presentation, you talked about what is necessary for a correct investigation. You said you needed time, resources and, above all, independence. Now there is a global economic crisis that affected the media. The economic resources are not the same as 10 years before in the editorial staff. ¿How do you see the stage? Can this lack of resources affect investigative journalism?

Tom Sanderson: I was talking about this, about the lack of resources as a major problem to fund investigative journalism. I mean as I said, they only spoke in my presentation, these skills are getting cheaper and their publication is getting cheaper, which is really not going to be a solution for any of us. Investigative journalism always requires time and money. Because obviously all of us have to pay bills and live. One of the problems that I think is in our society, is that we are getting used to being able to access things for free, since information and communication are often available to us. But then, why is not communication or information such as Google, Facebook or other mail providers free? It is because you are not really a customer in a relationship, you are the product. This is the business model of companies like Facebook or Google, where your data is as a product, not a service. And journalism does not work like that and we're always going to need money to do good investigative journalism and that's not an argument. Research in journalism is something that we should value and pay for it. That is an argument that should be made more frequently and stronger.

Paul Mena Mena: Mariana, the environment of journalism has changed. Now he is collaborating in investigative journalism, $¿$ what advantages do you see in these new platforms against traditional journalism? ¿Do you see an opportunity there? ¿What you think?

Mariana Neira: Well, actually, I come from the traditional media in companies that are already organized and have all the resources for mobilizations, logistics and to maintain a research group within the media, because you know that the media have to fulfill functions and there are only a few that are completely dedicated to research. Rather, since the elimination of the Vanguardia magazine, there are no traditional media dedicated exclusively to research. Then, of that merchandise that goes to digital media where I see that the problem is financing. I must applaud the creativity they have to survive in the search for sources that support them in this mission to work exclusively for journalistic research.

I think there are different audiences, we still have that target audience that has a preference for traditional media, and that is another battle between digital and traditional media because the latest statistics I had, and should have increased, is what, for example, The Internet in Ecuador covered $30 \%$ of the population. It is a fact that I had in 2010 and may be outdated. Anyway, let's say that the percentage has increased to 40 or $50 \%$, we have a large number of people who are not yet incorporated into digital media. On the other hand, it has become a generation gap. Traditional media are followed by only a generation of people and digital media are with younger generations. But those factors are the ones that will one day find a way to finance both sides, traditional media and digital media. 
Paul Mena Mena: Carlos, Mariana said that creativity is very necessary to get funding and keep alive a journal dedicated to journalistic research. Certainly, the realization of investigative journalism is not cheap and easy. l am a witness to working in a traditional media and see the effort that the owner makes is to maintain the research group. A few years ago, the group was a little bigger, now it has been absorbed by the daily coverage. Then, we can see the effort to maintain that. What is creativity? How in Plan V do you keep the quality work you have?

Juan Carlos Calderón: I worked with Mariana in Vistazo. Then, I worked in the research group of Diario Hoy, where we founded Blanco y Negro, a research column that lasted 20 years. After that, in Diario Expreso I had a research group where I worked for 10 years. And finally, the Vanguardia magazine that closed in June 2013. Then, as you can see, I worked in traditional media, as Mariana said, in organized media that had their own structure of commerce and administration.

Due to the crisis and the situation, they left us on the street. Avant-garde was closed and 13 people were left without a job, a photographer, a designer and the writing staff. So, what were we going to live with? Because that is the only thing we know how to do. And how are we going to continue to do our work with quality while doing investigative journalism? And so, we have the support of organizations like Fundamedios and others that always supported Vanguardia and said, "we can not allow investigative journalism to remain silent". And that was a very complex situation for Ecuador and journalism.

At that time, the Communication Law was approved, and Vanguardia closed. Therefore, there was some capital that allowed to install in the Building of the National Union of Journalists, a small office with two Macs for design and work. And that totally changed the perspective of being an editor, an interviewer or a media reporter to be an investment seeker without any experience. Imagine, I will almost have 35 years as a journalist and 30 of those years I had a salary list, worried about fighting against the commercial department. Now, I had to learn how to create this project, how to keep the job and how to sell it nationally and internationally.

And that's the way we've been working. At that time, we had 13 people and now we are four. People have stopped going, but we are always working. There was a time when I was the only one who was still in the project, but the next day I kept working because I did not know what to do.

One year after beginning Plan $\mathrm{V}$ we continue, in one way or another, the diversification of the search for sources and launch projects with international organizations that help us continue with funds or with the search for support in the sale of memberships to people They supported the plan V. We had to reinvent and create a company that can help us distribute and sell the project. A company that had nothing to do with us, with me, because the government was responsible for making me look like a toxic person, because I was stigmatized which made it much more complicated for me to have people support me in this project without fear. We have found resources that allow us to cover certain needs. For example, pay the office, Internet, mobilization, salaries, collaborations.

The problem with Ecuador is that there is no experience in paying to receive quality information. The main point, I think, is that advertising paid the bill and at the time it is digitized, in this type of project, especially for the graphic press, you have to find someone to pay the bill and in this case, it should be the public, the people, the readers. We once had a conversation with a correspondent in the Netherlands, who taught us how they work and we are trying to apply it, but one of our main objectives was to create a commercial structure because none of us knows how to do it, we have learned to sell, to do projects, 
but we have not learned to manage it and we still have a way to go.

Paul Mena Mena: We understand that today there is a direct relationship between civilians and research organizations and journalists. We have already talked about how journalistic research is fundamental for democracy, but at the same time working with civilorganizations is fundamental for the development of journalism research. You can say Tom, from your experience, ¿how is that relationship made between the journalist, civil society and organizations?

Tom Sanderson: It can work very well. Some examples are civil society organizations that have several journalistic practices and skills to deal with important stories of public interest. However, there are more questions about the objectivity of what a good journalistic investigation needs. There are cases where NGOs have done research work and they have not published it because their function is not journalistic, but they publish what fits in with the campaign. However, for meit means that they are not doing journalistic research, they are simply campaigning. All journalists must have objectivity, regardless of the certain perspectives that come from the fundamental ideas that shape our research and our conclusions. The point of a good investigation is that the journalist must have a high level of objectivity.

Paul Mena Mena: Tom made us consider the close relationship between sources, in investigative journalism when faced with great powers, because that is the work of journalistic investigation, to give birth to something that someone powerful wants to hide. Without a doubt, journalists have to work under a lot of pressure from people in power whether political or economic. From your experience, Mariana, ¿how should we face to maintain independence and objectivity?

Mariana Neira: In reality, it is a complicated issue. I have experience in the media that I have worked. In Vistazo we present a complaint about purchases of war tanks. Before its publication, a soldier read it. After reading the article they spoke with the company manager to put pressure on them not to publish the note. In the end, we do not give up the pressure and publish the article. However, I have noticed that not all media can handle that, because they have an economic weakness that makes them renounce pressures, especially small media, and that is the biggest challenge for people who have been involved in the creation of media are traditional or digital.

PaulMena Mena:Independence and credibility are the greatest inheritance we have as journalists. Juan Carlos, taking advantage of being in front of a young audience, who are students of journalism, sometimes we take into account that a journalistic investigation is a kind of detective that is pushing itself in private lives, something that is not very real. Anyway, there is some ethics in investigative journalism that easily marks those limits. You can tell us some of those ethical limits within a journalistic investigation to understand the difference between the private life of people and a journalistic work.

Juan Carlos Calderón: It has to do with the public interest. Everything that has to do with the public interest is a subject of journalistic research and the limits have to do with good ethical practices. Without ethics, journalism is not possible. Any work is not possible without ethics. And good journalism research practices and journalism in general must meet two specific objectives. Avoid that the information is manipulated and does not answer the interests of the organizations. Because all the interest groups, whether the government, the armed forces, the religious people or any other group, always try to put the information under their own services, above the common interest. In the world of writing, you will always find that. And the job 
of a journalist is precisely to prevent this from happening. It's not easy, but I only think that from my experience.

All of us have had experienced with censorship or people who want to force you to be censored. In Diario Expreso, I had a bomb in my hand because I discovered that the military base in Manta had become a port in the United States with the excuse of fighting the drug cartels. In addition, I had access to the report, the proof, even the testimonies, and they told me that they could not publish because they would get several problems with the United States. And I annoyed everyone for three months until they told me: "let's publish".

This is how you do it. Now, ¿why do we publish that? Because it was a good job, because our job is publishing. In any circumstance, our obligation as journalists is to publish. The difference is that we can make a journalist work using sociological or ethnographic techniques, but at the end of the day our job is to publish that. If not, it does not work at all.

Now, I'm sorry for not answering the question directly, but in the sense of how they differ between the private and the public will know once you start working in journalism. In fact, the public is what everyone is interested in, and if an authority has a lover it does not matter, but if the lover is being financed with our resources, then it is important.

Paul Mena Mena: Let's make a quote, Tom gave a definition about what is public in his conference; He said that everything that is of public interest is what refers to acts of corruption that affect society ingeneralormay affect the health or welfare of society. So, in that context, an email that contemplates the common interest can be revealed, since the journalist's ethics says that itcan be published, but if that email does not have that kind of information, then that is private and the ethics of journalism He says he has to be considered as such.

Tom, the journalist figure was changed in the sense that before we could find these brave journalists who could make some great revelations, but now this figure has been lost and instead has given relevance to the figure of a journalistic collaboration. We have witnessed the Panama Papers and Paradise Papers made by ACIG ¿What are the advantages of working collaboratively?

Tom Sanderson: First, I must make it clear that my organization is the $\mathrm{CI}$ is not $\mathrm{ACIG}$, so I have not personally worked with the Panama Papers. But I believe in the benefits and this trend of collaboration between journalists is very true. Journalism and industry have been seen as individual work, to maintain the result of their work for oneself. But we have seen in the last three or four years a true movement towards collaboration between journalists either nationally or internationally. The $\mathrm{CIJ}$ is the prominent example of that or, the EIC or, Investigate Europe, who decide to publish great stories of this different national context with a different language, but with international relevance. So, there are many benefits in these new types of ways of working. First, because you can make a story that may be happening the same in other contexts. Second, resources can be shared. Third, and possibly the most important, the trustbetween the journalist begins to build. The construction of connections begins and begins to share the experience and skills, which would not have been shared in any other way.

I know that the ACIG had at least two meetings, most of their work was done through long distance communication and face-to-face meetings, to build trust, but also to share experiences and find angles that could be useful for the contexts of another person, but that would not be accurately useful for the journalist on how he found them.

Therefore, outside the collaboration there can be no stories, for example the Panama Papers papers would have been lost because the 


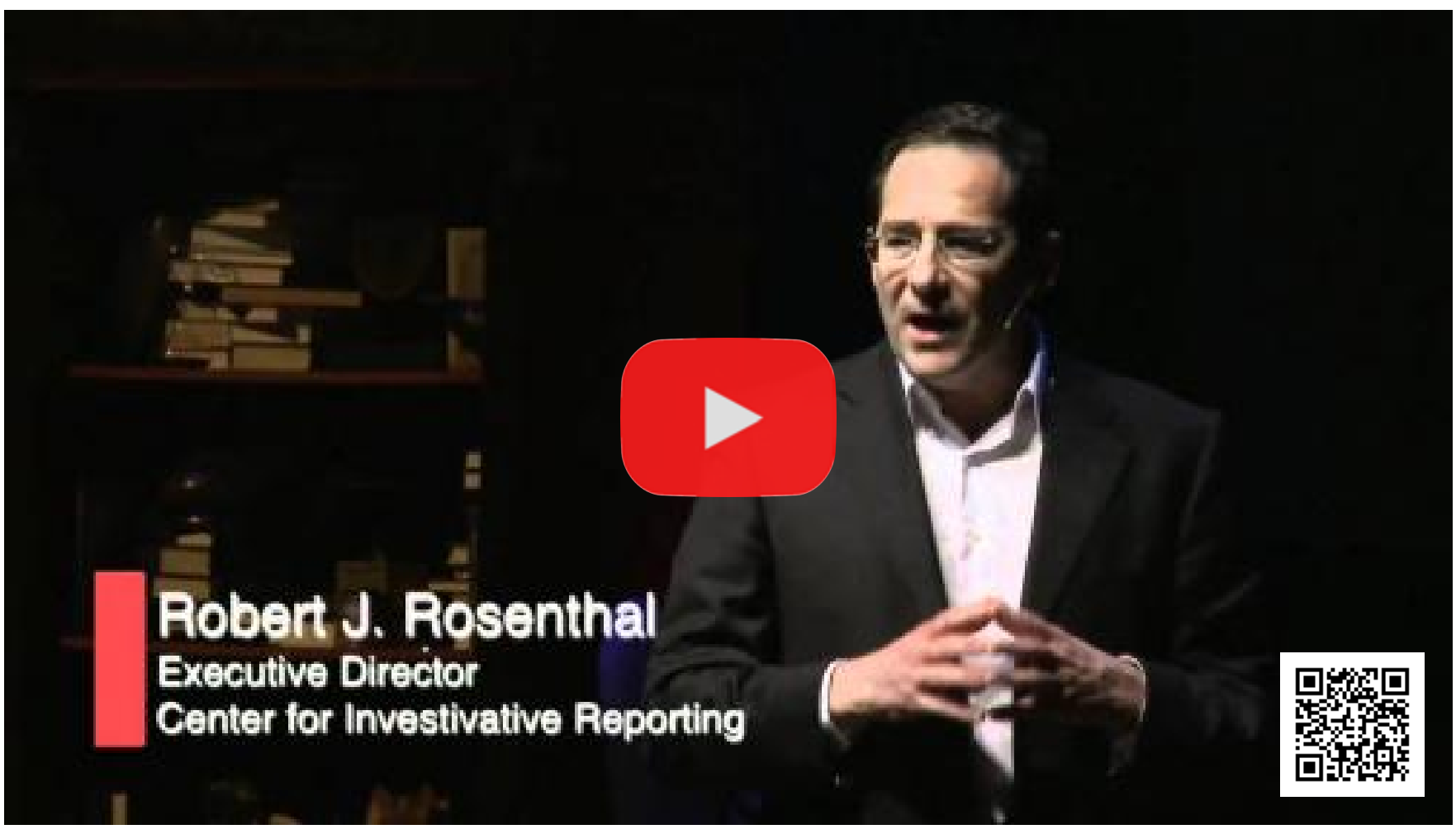

journalist who found them could have thought that it was not relevant enough to put them in the story. On the other hand, with these collaborations it was possible to go directly to someone else who could be interested and above all to interest readers. We get more from the recovery of research work and leaks than the production of this kind of stories.

Paul Mena Mena: Mariana told us about your personal experience with the government, with the closure of Vanguardia and this idea that has grown from the impossibility of doing investigative journalism in our country. Now the context of politics has changed. We are with a new administration, but ¿what does this new environment look like? ¿What is your thinking about it?

Mariana Neira: It has changed because there is no need to investigate. I think there is more adrenaline in difficult circumstances. I mean, investigative journalism has to do impossible

\section{"The journalism job is to defend the public's right"}

things in authoritarian governments to find information. And that is what we experienced in the last decade, when despite the law and information transparency, we were denied important information. Then, there was a challenge for the journalist in finding other ways to search for information. There were many obstacles that we had to overcome and that is the difference, in working in those types of governments.

Now, in more democratic governments, there are more facilities to do research work, let's say yes. Moreover, we never have to renounce our basic objective, which is to be attentive 
to the State, on how they are managing our resources, the degree of transparency or the degree of corruption in their actions.

Paul Mena Mena: Juan Carlos, Plan V created the Corruption Museum, which has been very well received by the public. And now an innovation lab oratory has also started and you can see that there is an excellent database work ¿How do you see the data journalism tool to start research topics? ¿How are you working with this and what are the consequences of this application?

Juan Carlos Calderón: I think that journalism has always worked with data. The important thing is that these data are real. Now, I think that investigative journalism in our case has taken a leap to digital design or new digital narratives. In general, what we used to do and continue to do, in some cases, is to write a lot, a lot of text with additional resources such as multimedia images, infographics and that is to think in digital and not in digital narratives.

The Corruption Museum was born after the former president said he was going to leave a gift museum, and in fact he did, so we said, "¿why do not we make a museum of corruption cases published in the press? ", And there was so much information about cases of corruption that were forgotten that we asked ourselves how to work with this amount of information and instead of putting 60 great stories in a book, we decided to make it public and easy to search for information.

Therefore, we made the museum where the person who is looking for can find all kinds of information in cases of corruption and if they are interested in a specific case they can continue investigating in the museum for more information. So, this was generated thinking digitally in a digital design. We learned how to design the information we had and how to apply it to new narratives.

We had another experience in the last elections. We had to inform the elections, so, as always, it was going to be a chronicle and follow the candidate and his campaign group. We could have the same chronicle of 20 years ago and only change the names. So, we tend to repeat, now the question was "¿how to inform the elections thinking digitally, with digital narratives, with digital designs?"

We invented a virtual ballot box so that our public, who did not know much about the candidates or their proposals, knows the candidate. In addition, the young people did not have any candidate to represent their interests. So what we did was to bring together a group of young people with an NGO called Citizenship and Development and we made focus groups and from them came many questions for the candidates. Ten questions and all these questions were for all candidates. And then we build a database with these answers and we invent an algorithm in order to combine these responses and that the voter participates online.

The public also answered the same questions that the candidates answered. They answered the same questions yes or no. For example, "¿do you agree with abortion?" Yes or no. Ten questions answered by the candidates and also answered by the public so that they could see who gave the same answers. Then, in this way, the public could see the coincidences with their candidate or which candidate matches their response. There were complex questions. "¿Do you agree with equal marriage?" Yes or no. And the public played and voted digitally.

People started playing and we saw 150 thousand visits in a week. In addition, the current president, Lenin Moreno, was the only one who took some time to answer the questions. Then, when he saw that we had so many visitors, he called and asked: "¿Why is not he there in this game?" And start playing as well. We did the same for the second round with Lasso and Moreno. Therefore, it is all about the search for new ways of thinking about information digitally, both in 
investigative journalism and in a news juncture, as well as in the same way as you imagine new ways for the public to participate. And that is the great advantage of this digital world.

Paul Mena Mena: Tom, this trend that is in data journalism, is difficult to put into practice in Ecuador in traditional media. The understanding that now the Internet has millions of loose data to tell a story to the audience, requires a level of experience that the journalist has not learned in their universities given the novelty of the topic. There is the idea that a programmer should be part of the writing, but the idea does not fit well in the traditional newsrooms. And journalists have started to learn programming and it's very difficult. What would you recommend to solve this? ¿ls there a great opportunity for data journalism and what is the best way to integrate this into our writing?

Tom Sanderson: I've had this discussion with people before and it's probably easier to teach a journalist to code than to teach a programmer how to do journalism. The fact is that there are some instinctive elements in the practice of journalism, which are difficult to teach someone, you can only learn from practice. While coding once you have a decent ground connection and the logic of how you function, you can teach yourself easily. Thus, one of the newest training courses that are being run in $\mathrm{Cl}$ is an introduction to coding for journalists taught by a couple. One is an encoder who works for an important position in National Statistics and one who is a data journalist who always worked in the Times.

The idea behind the journalist's training is to explain the benefits that can be obtained from coding, as it is very necessary; At least in the United Kingdom, it is important for publishers to introduce some knowledge of coding in journalism, since many times an encoder is hired, but they do not really understand whether they should have an encoder or not and the encoder ends up sitting in the corner and eventually someone will ask you to do infographics.

Having said that, there are other misconceptions about data journalism, such as the need for technical computer skills. Many of the stories you see in traditional media, come from data. Everyone is working from data and, in fact, some of the best data journalism stories do not contain any data at all. So, I'll go back to the analogy that I used early. The use of Excel, for example, to work with information, should really look like an interview, like any other interview conducted through a different language. Therefore, it is really the same as learning French when interviewing a Frenchman.

Public: We have talked about collaborative journalism and how journalists can help each other ¿How can journalists collaborate with another area, not necessarily between colleagues but with people from other areas who ask questions of the same subject? I am talking about a true multidisciplinary writing group to work on an investigation ¿How can this be done and that benefit long-term investigative journalism?

Juan Carlos Calderón: In fact, all journalistic work is always an act of flexible cooperation and cooperation. Otherwise, only a journalist does not exist. Journalism is something done with others, for investigative journalism this one of the fundamental resources. The technical sources allow you to know the subject. One has to go to the search of a network of contacts and sources, in order to relate all the information and prove his hypothesis. That is the work that one does, but yes, in fact, one depends on other experiences and technical sources to understand things that we do not know. What I want to tell you is that, without relevant sources and techniques, it is not possible to do good journalism.

Tom Sanderson: Yes, I suppose we can reach that conclusion. I think we should be less worried about not doing the work of the 
powerful who want to prevent journalists from investigating their actions. In fact, it means that they do not need to do that work. Therefore, think of it as a much more pernicious problem in the investigation of journalism, self-censorship, the questions we do not ask because of the possible risks.

Public: We were talking about the pressure of the correspondent doing research $¿$ Can you please tell us your own experience with the pressure, while doing an investigation and what is your reaction?

Juan Carlos Calderón: The biggest pressure was not when Rafael Correa asked us for 10 million dollars of compensation for the Book of Big Brother. The biggest pressure was when I had to flee from the FARC on the border, in the Putumayo area. We were doing a story in Vistazo. A report on how the FARC groups were on the border guarding the cocaine laboratories and the coca crops. said "these Vistazo reporters published a story and now we want to kill them." Then, with the photographer we lit our cigarette, possibly the last one we smoked and we said: "¿what can we do?" And the answer was "let's go running". So, we saw a boat on the river and we jumped and started swimming and were able to get to the boat and escape. We were chased to Lago Agrio. So far I have not come back, I do not know what could have happened, but I think it was the most serious moment I've been through. Now it's pretty fun.

Public: ¿What tools to use to avoid doing something personal? Last year we talked a lot about Rafael Correa and several other issues were left behind because of that ¿How can we know which are the tools to use and do more research and not get caught up in a topic?

Mariana Neira: We always talk about where the limit of the investigation is and I'll come

\section{There is the idea that a programmer should be part of the redaction, but the idea does not fit well yet in traditional redactions}

We made a large report and interviewed the guerrilla leaders in the area, the commander of the front 48 and then published the report. Then, a friend told us that we became a military target thanks to that report. For that reason we did not return to the area.

A year later we came back to report a disappearance of a technician in a construction business. We foolishly returned to the FARC zone without any security or protection.

We find the same people we interviewed a year before. The advantage was that they did not recognize us and one of the supporters who held us told us that he was going to look for his commander who was the commander with whom we spoke a year before and as he back to tell you what happened to the prosecutor this week. He told me "but you must know who is the suspect of the disappearance of this person" and I said "I'm not here as a prosecutor, I'm here as a journalist". We, the journalists, make an exhibition of the data, it is the way in which people have their own conclusions. We are not the judges, so that is the limit of our work because the confrontation is made by the authority. There is a thin line between investigative journalism and the legal, prosecutor and judges. At least that's the way I do my research.

Public: ¿And how not to do a repetitive investigation? ¿How do we not turn it into a personal investigation? 
Mariana Neira: I do not believe that research is done with personal reasons, unless it is biased or politically manipulated. I'll tell you another anecdote. I had a guy who worked with me and I was working in a public environment at the beginning of this government because they introduced me to the idea of public media. I read and studied what this concept meant in Europe and it caught my attention. I was given a group with a journalist when the path of public media began to go differently and depended on the government. At that time, people began to get nervous. I told him that we had to do this investigation and he said "¿in whose favor? ¿The government or the company? "I said "no", the investigation was not done to be in favor of something or someone. The investigation is the confrontation of the facts and evidence in the way in which a conclusion is established can be said that a person is indeed a trafficker or not, for example, there are some cases in journalism where the investigation stops because if we had a case of corruption, but we see that this is not true, we prefer to stop and eliminate that report and go in a different way.

The research depends on the editorial planning. In large media, the staff meets every day and determines the topic to be discussed and the steps that must be taken. But you say, "¿why do we always go with the same theme?" There are other groups that criticize us when there is continuity to certain stories and when there is no continuity to the stories there is no conclusion. Another example of human rights is that if we, in the 1980 s, did not give continuity to these investigations, we would not have discovered, or partially discovered, the case of the Restrepo brothers. We went back to the history; we interviewed the family, the legal process, until the judges determined that it was an enforced disappearance. So that is an objective that we seek as journalists.

Eric Samson: I spoke with a student who had doubts about the race and I told her a story in which I could make an important change. Can someone quickly explain an experience that has changed something or did the right thing so that students know that this race will not make us rich, but we can change important things in the world.

Mariana Neira: One of my satisfactions was the achievements we had in some cases of disappearances in the 80 s.

Paul Mena Mena: I can talk about the experiences we had with the Panama Papers where we made a great report about how a Chinese company falsified some invoices and reports in order to evade taxes here in Ecuador. The result was partially optimistic because on one side the SRI could charge 65 million that evaded this company, but on the other hand some legal investigations were opened as falsification of documents and in a very suspicious way a prosecutor said that since the Chinese have already paid the 65 million dollars, there is no crime. That is a double standard because we have noticed that in other cases prosecutors have had other trials. It is that they do not like it, what I already paid what I evaded, there is no crime. No, there is still a crime in other cases, so we must give continuity to that issue.

Juan Carlos Calderón: I did an investigation into a story about a woman who was in prison for more than 12 years because she killed her husband in self-defense, because he wanted to kill her. She was a victim of violence for more than 30 years and she killed him in a fight and was sentenced to 12 years in prison. I did the investigation and proved how the murder really happened and how the judges did not see it. After the report a group of lawyers took the case and she got her freedom. I think one does journalism to help people.

Tom Sanderson: I would just like to return to my example and show that, although there are always people who try to take the means and influence in ways for their own specific interests. These are also ways in which we recover our media as a public and we do it on all of us. \#PerDebate17 


\section{Now \& Then}

"I think that journalism has always worked with data. So, what is important is that those data are real. Now, I think investigation journalism in our case has given a jump to digital design or the new digital".

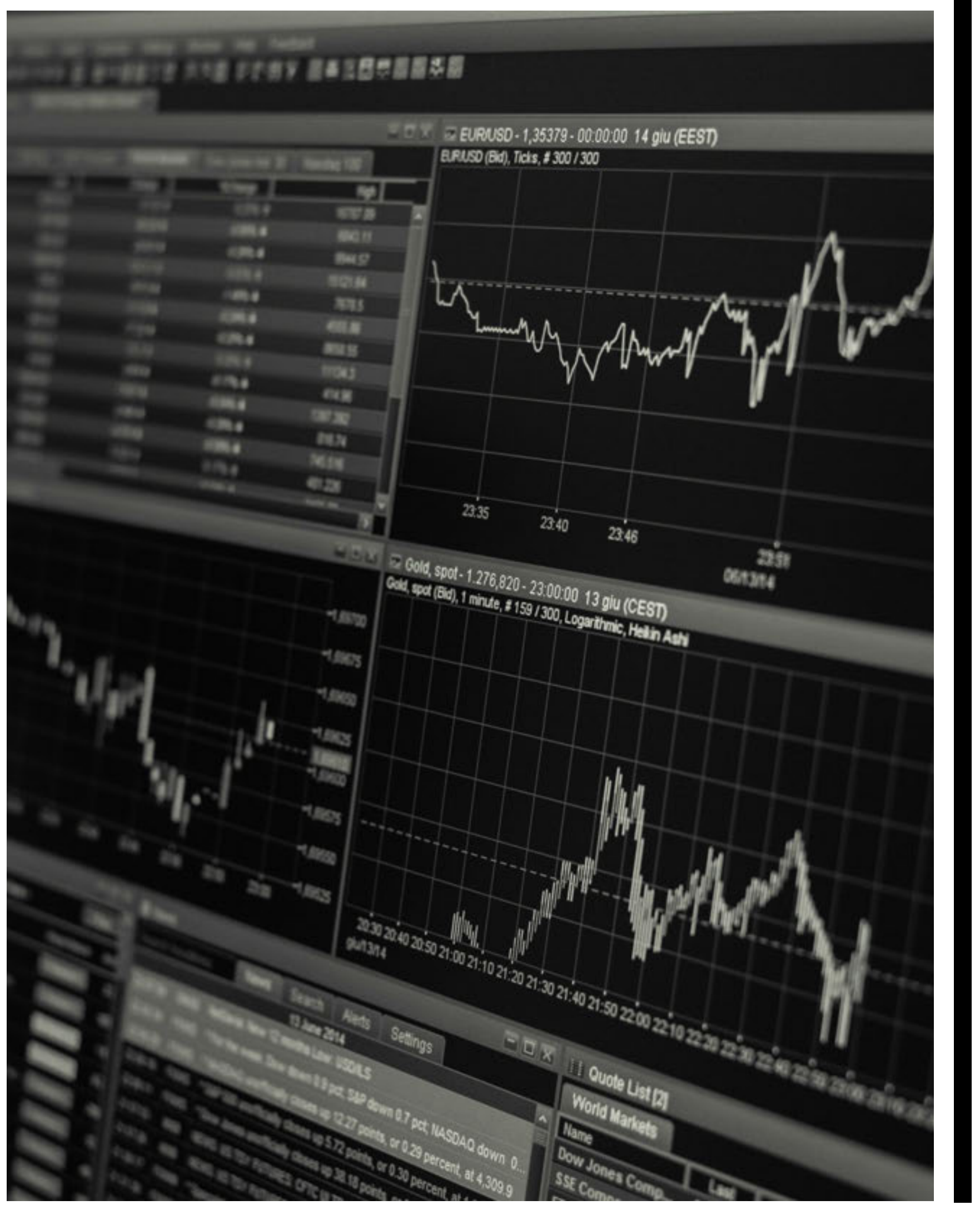




\section{Christoph Geiseler,}

Founder and CEO of Seenfire Foundation (USA)

Back to Index - Versión en español

\section{Keynote Conference: "Video Production in Viral Micro Tales, a Macro Tendency"}

Christoph projected the video of a Mexican boy building his own company; the next video was an informative one. Between the two, the similarities were that they have many images and lasts 60 seconds exactly. Therefore, it can be something that promotes a product, something more informative, but time is what it has in common. These were made by two Christoph students, one this week in Guayaquil and the other last year.

In 1997, Christoph received his first camera and 20 years later he continues doing the same job, traveling and recording. Something happened between those 20 years. Upon graduation, his father asked him: what do you want to study? He answered photography and his father said, impossible you should study something serious. Christoph said that a photography career was serious and that being an artist was his dream. But his father said he should go for something more serious where he could earn money and be respectable. So, he said: I will study politics, so that his father is happy, and so he will learn some things. He thought that four years of politics was too much, so he decided that he really wanted to be a photographer. Ironically, he now works in 60 American embassies where he learned never to say never, because sometimes his work has something political or cultural and that has to explain what it is to use a video.

Visually speaking, ¿how can we use videos to communicate what is happening? First, ¿what are one minute videos? They are short stories built on an international narrative and involve viewers in a digital ecosystem. So, the two important words here are: international narrative and digital ecosystem.

The international narrative means that, if we put a video on the Internet, a person will see it in Quito and another in

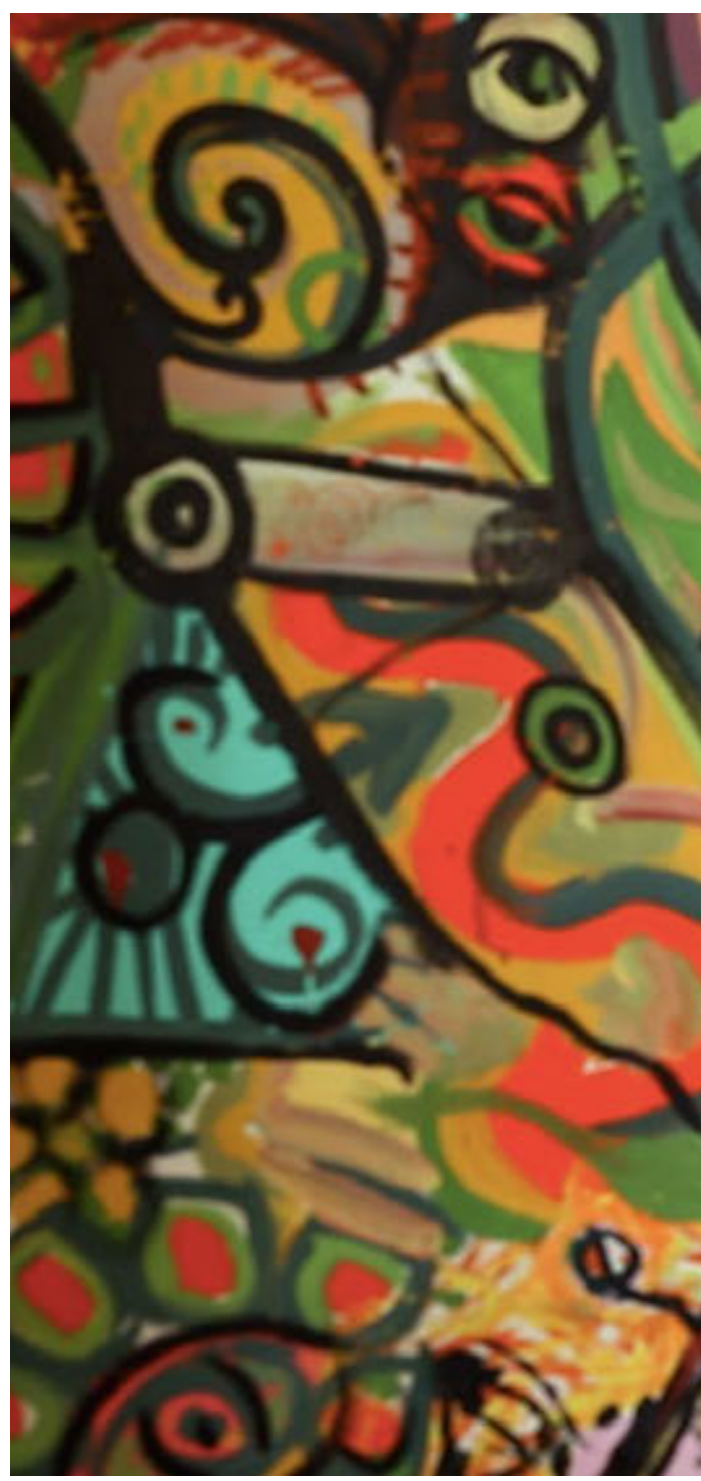




\section{Day 02}

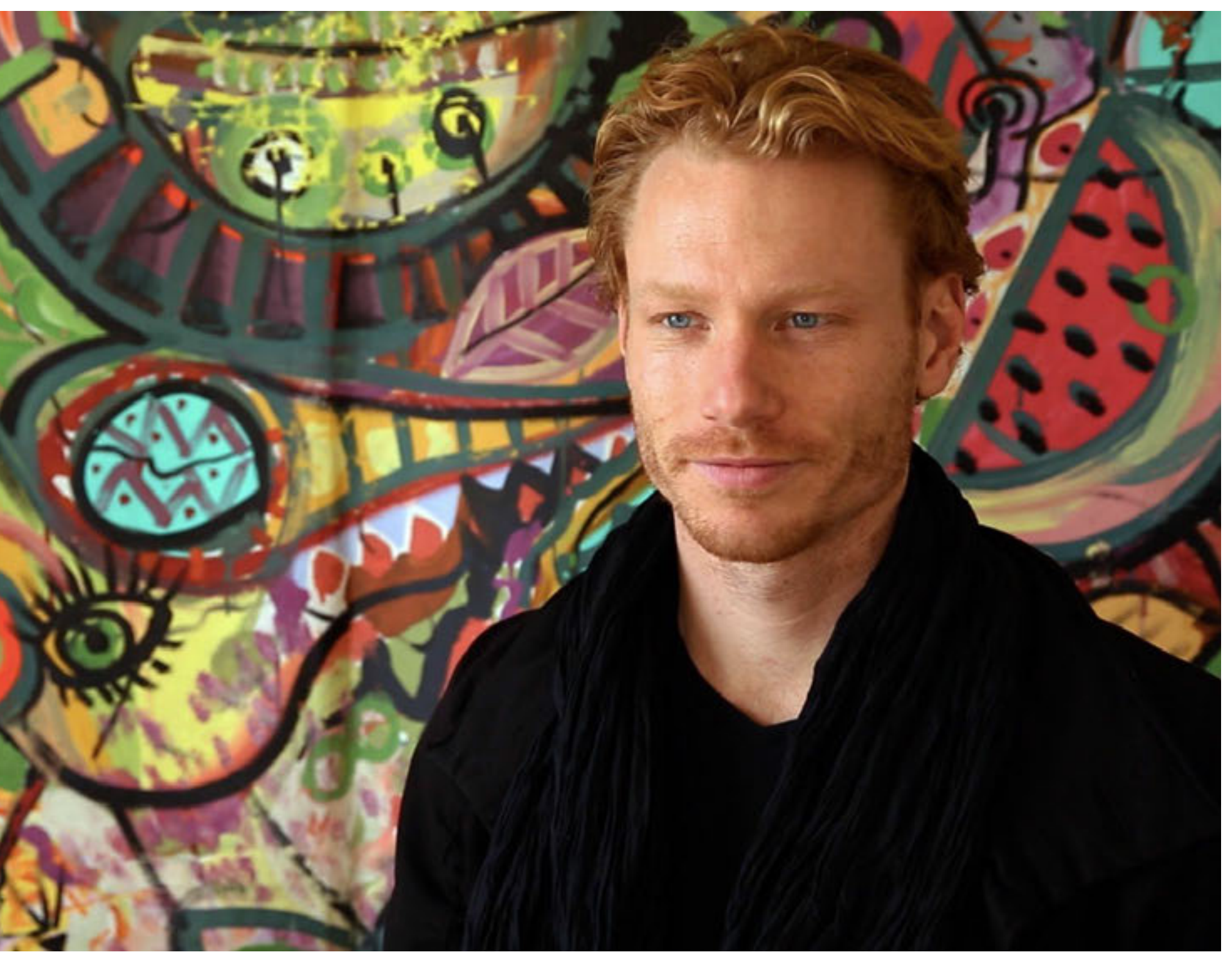


Australia, which is international. They do not need 20 people to watch the video and say that this is international and that is important, it only takes two people to watch a video and have an impact, and it also means that we never know who will watch the video. So, we have a great responsibility when making videos. The digital ecosystem is to think that this ecosystem is a jungle, that's why we make tweets, comments, blogs, photos, music and videos, and how we know what people use.

There is a lot of competition, each content fighting against each one. We have to know what content would be more likely to be seen by a person, and it could be frustrating or boring, but the fight is always there. Therefore, what Christoph wants is to show the ecosystem in a more interactive way, where everything is connected. It means that, if we put a video, someone could take the music, someone the photo another the idea. The idea time, if you try to make a video, you will feel stressed and confused about how to do it. The recommendable thing is that, if you start editing the videos, and it starts to become stressful, you have to stop, go have a beer, call a family member, watch a movie and re-edit when you feel best. Because making videos should be fun, and the moment it becomes stressful, it's not worth it. So, that's the philosophy you must have.

When we think about making videos, there are three phases. First, preproduction. It is all the time before making the video. Logistics, recharging batteries, requesting permits, buying tickets, rental equipment, everything that is preproduction. Because the second we start recording until you finish recording, it's called production. Where the sound and images come from, the interviews and the whole recording. And, finally, we have

\section{Everyone is thinking "or we have the video for} tomorrow or Snapchat for today", but maybe that is what our grandchildren will see in a hundred years.

is to share it, and that will happen with our video, but at the same time we can do the same with another person's video. That is the idea of boosting and recovering videos. Content is always moving in this digital ecosystem. So, you can see it as a competitive ecosystem or something more synchronized.

Now, there is a cost when making videos. First, the staff. Someone has to make the video, someone has to record. Training, someone has to be in constant learning, like us at this time. We need resources, who pays the plane, the trips, the batteries? The equipment is also necessary. Or you can buy a phone or a camera, but there is a cost behind that. Startup. When we are making a video, we have to plan it, it takes time. Also, security, since journalism is a risky profession. These 6 words make one that is STRESS.

Making videos is somewhat stressful. At any postproduction. Ihat's all that happens after the recording. From the program that we are using to edit, where we are keeping all the content recorded, how we are sharing and what happens with these stories in a hundred years. Everyone is thinking "or we have the video for tomorrow or Snapchat for today", but maybe that is what our grandchildren will see in a hundred years. So, we have to think about the present, but we also have to have the vision in the future. So, ¿what is our strategy for making videos?

One-minute videos require discipline. It is minimum 1 minute, maximum 1 minute. That is the easiest and ironically, the students can not accept that. Therefore, the videos are not for us, they are for the public and we have to accept that they do not want to watch videos that are too long. That's when we have to have 
a lot of discipline to be able to put as much information as we can in a minute. Another thing that is important is to be able to shoot and edit in 24 hours. Sometimes people think that, if they can make a video of two minutes in two days, and so on, videos of three minutes in three weeks. That is the idea, to make a video of one minute in a day with the aim of reducing the time and cost of pre and postproduction. It does not matter in which country or in what situation, if you go to your boss and tell him that you can reduce costs, you will feel happy. So, the idea is also to have an advantage over costs and time.

The structure of a one minute video is first, music. Music attracts people. There is a difference between jazz or rock and roll or watching a video with classical music or folklore. Each type of music brings a different emotion. So, we have a narrative or an interview. If we are doing a one minute video, the maximum number of words is 150 , because after that number of words, we have to talk very fast. The video is also important.

The videos and photos reinforce what we are tryingto say in the narrative, when we promote a product, when someone is watching the video, they are listening to music and they are receiving information and looking at images.

There are so many active sensations. But the videos also have to have a challenge, if we are making a video about recycling and the stars of the video say: "my company is the best in the world because we are recycling". That's boring, because it's a manifesto and we do not want that, we want authenticity, but if we start with a challenge like: I live in Quito, and I see a lot of garbage in the street and it's a problem, the public will say, "Yes, that's real, I've seen it." Then, it goes to the solution.

If the video starts with a challenge, the audience wants to know the solution, then we show them the solution, with images and videos to call the action. And with that call, we invite people to visit a website, call a number and be part of that movement. The users want to have that vocation.

You can also write a new narrative about a record over and over again and use it in the video to reinforce the information you want your audience to hear. So, the question is, chow can we use one minute videos? First, for products and advertising. For reports, journalists have to report on the same day. For obituaries, celebrate someone's life. For fundraising, in order to invest in a video to call people to invest in the business, ideas, dreams, everything.

For a vignette or instructional videos, even to leave, because someday, Christoph thinks that, instead of a photo, in our social networks we will use videos to tell strangers who we are. The one-minute videos are also useful in the job application, he wonders if in Ecuador this trend has begun, but surely he believes that it will start soon. You can talk about the experience and be able to show how you talk, how you dress. Finally, to give your opinion. All these uses spell PROFILE VIDEO. Facebook has millions of users and when you tell us, you can now have profile videos, everyone does it. What images are we going to use, what music is appropriate, so, if it is not happening now, it will. How my profile video would help me interact with others, find a job, find love, friendship, anything.

So, ¿what is the impact of teaching videos? First, video literacy. We go to school to learn to write, play musical instruments, study culture and history. But ¿when are you going to start showing kids how to make videos? Surely, the videos would be part of education. So, it's important to start and learn that now, giving us an advantage. Then, people can have more creative confidence, to do something more personal, artistic or inspiring. Finally, empowerment is when someone, a neighborhood or town learns to do something new. From literacy to empowerment, it is a novelty to have a social impact. 


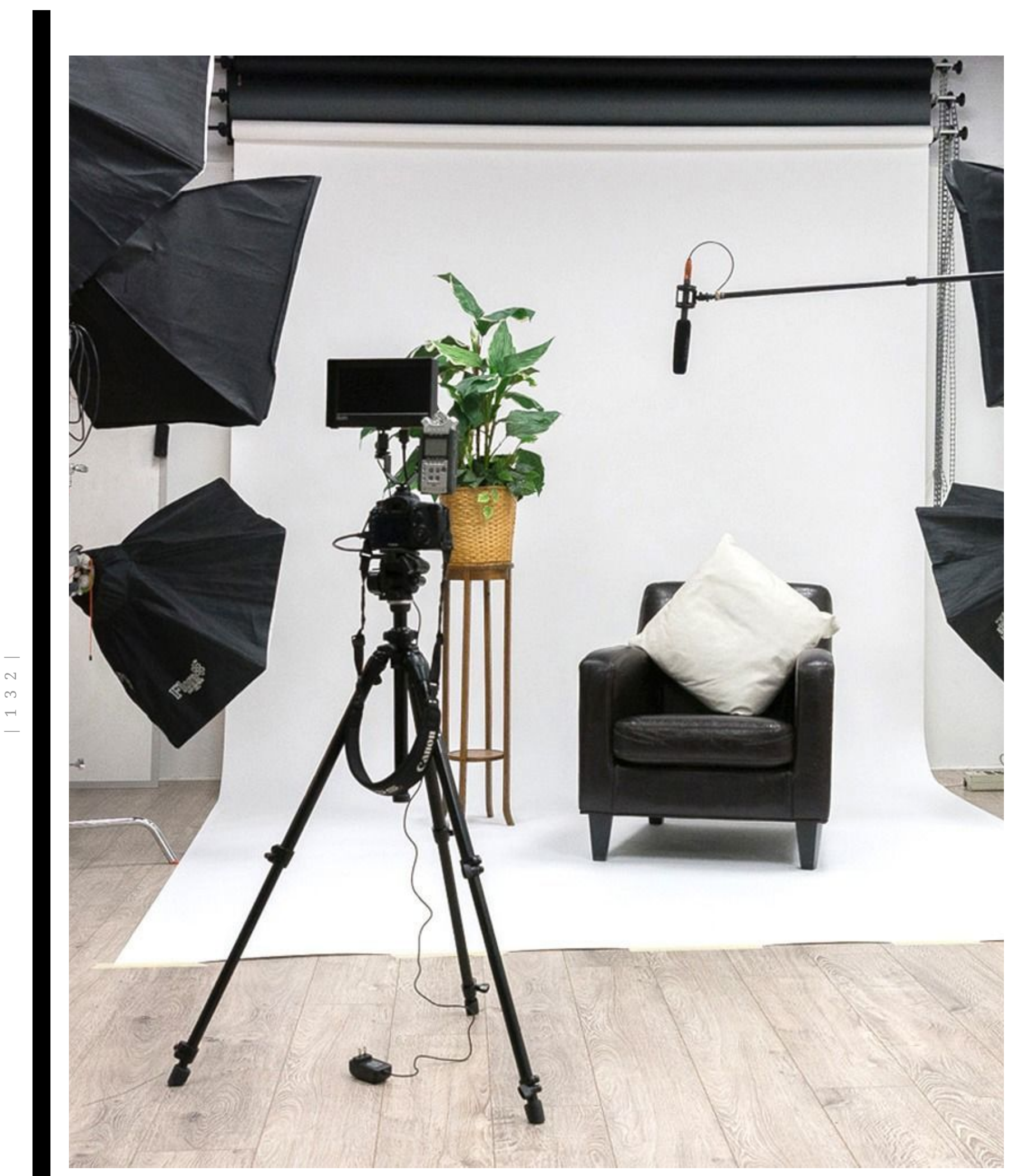

A new way of doing journalism

The tendency for information to be increasingly concise is booming. It is time to understand the new needs of the target audiences to which our environment is dedicated and thus be able to provide quality material focused on the new needs of both the media and its consumers. 
$¿$ What is the logic of one minute videos? Set expectations because people like short videos. Reduce costs because we do not want to use more money and more time to make videos. We want to reduce that. It also reinforces a brand that people in the video can use on T-shirts and throughout the video. It is also entertaining because videos do not always have to be serious, they can be fun.

The video also gives authenticity and people want to see something real, something authentic. It is a media file, as he said, what will happen to our stories one hundred years later. If we are lucky, we could have a picture of a black and white grandfather, so imagine that our grandchildren could have videos of ourselves. Imagine that difference in this intergenerational experience, to preserve the culture or the family.

Also work as a logo location, so instead of making a 5 minute video, ¿why do not we make 51 minute videos where you can see your logo more times, plus I can ask for more money? So that's also a way of doing business, people will pay the same for a 5 minute video or a 1 minute video. Increase transparency If we are sharing the truth, journalists and organizations want to tell the truth. And finally, narrative videos that have a story, a voice behind the video is easy to teach friends or students or a child to make a one minute video of 35 minutes. By using all those words, we can write STREAM LINE. That means that it works intelligently. Well we have strategies and methods to make one minute videos, we can use less technology and have time to do more things. So, if we learn how to use technology intelligently, we may not have to use it.

In a more interactive conference, Christoph explained that, in the first place, it is necessary to ask if the video is commercial or not. At the end of the day, all we are trying to do is earn some money. Therefore, it is important to determine our target audience and there is a big difference between making videos for children or children. For example, we are making a video for 80 -year-old men who love poker or a video for ten-year-old girls who like to play with dolls. These are two completely different audiences. For men who play poker, they may want to listen to classical music, but if you put it on girls, they will not work.

You have to use what the audience wants to hear. Afterwards, ¿who is talking? For example, if we are making a video about women's rights, we would have a woman talking or if our audience is 80 years old, men, the best narrator is another 80-year-old man who speak because they can identify. Those are decisions for who is the best narrator for your audience. Another

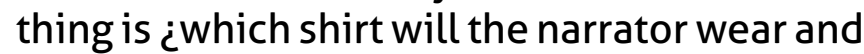
even which images are we going to use? ¿Are they photos, videos and even what filter are we going to use?

Christoph encourages the entire audience to write a video that they will do ¿What story will they use? ¿What audience, with what music, narrator, costumes and images? Then, he had everyone share it with a friend. This process, as he says, helps people who work with schools to tell what they are planning to do, before looking, people who have listened can give advice to do so. In the worst case, if you show it and there are people who do not like it, we have to start all over again.

He showed how to use the camera. He made everyone stand up and gave advice on how to use a camera. Christoph stood up with his feet apart and his elbows beside his body. The thumbs should hold the phone from the bottom of it. He also said that the least it records is 10 seconds, so it can be edited.

The final advice was to take all the time you need to make the perfect video. Aesthetics is very important, follow the rule of thirds, use the routine and use the best light and audio for your photos to affect your video and its impact.

\#PerDebate17 
Toa Maldonado,

Co-founder and vice president of APAK, producer of Kichwa television

Back to Index - Versión en español

\section{Conference: "Intercultural Production of Otavalo"}

Toa is part of the association of Kichwa producers, APAK, an association formed by Kichwa Otavalo people.

In 2006, a group of four young people from Otavalo with a Puruhá girl started a project to launch a televised cultural magazine. It started because for many years the Kichwa cultures saw reports in magazines or documentaries that talked about them, but none of them was real. Most of the time the cultures were exotic or folkloric.

In Toa's experience, when she was about 14 years old, an English researcher arrived at her mother's library in Otavalo. He started talking to her and became friends easily. Two years later, her mother received a book of stories of indigenous women in Ecuador. His mother checked and showed Toa what he has inside. Where was the story of his mother and was like reading a folklore story, very exotic. His mother is Kichwa

\section{When Toa began to get involved with APAK, he understood the need to build and promote an objective content of what the Kichwa cultures represented.}

Otavalo and his father is not, so Toa has always been recognized as Kichwa Otavalo. In that book, she was interpreted as a bastard daughter of half blood. His mother considered that book was a joke to remember all the women portrayed there. The book was a PhD thesis of this English woman and published in Ecuador. Her mother never saw her taking out a tape recorder or taking notes, so it seemed that the whole story came from the mind of this researcher.

This story was a very personal experience of Toa, but she has always felt that she is the best example to understand how her cultures have been very exotic in the media. That is something that does not represent them. Later, when Toa began to get involved with APAK, he understood the need to build and promote an objective content of what the Kichwa cultures represented. 
In 2009, APAK is legally compliant with the need to find funds from the State or other organizations to be able to work. For years, APAK did not receive any type of money, but rather it was self-financed with any audiovisual video that was requested from local merchants. In this way, APAK began to grow. One of the first reports they did was "Mindala", which spoke of the oral memories of the people of Otavalo as travelers and traders from around the world. The project took more than a year in its manufacture and one year in the edition and publication.

Toa explained how interesting the making of this documentary was because, wherever he goes, he always finds a Kichwa Otavalo person. What the documentary did was to take all the oral histories of four communities in Otavalo, they talked about the importance of these migratory flows. He recalled that in 2005-2006, the president of the time said that the Otavalo are the cultural ambassadors of Ecuador, because more than taking art and music, they bring culture and traditions wherever they go. In addition, Otavalo became the center of tourists who wanted to see this culture.
Mindala meant a category that was visible for many years and managed to get many Otavalo to recognize themselves as Mindalas, not only travelers or traders, but cultural ambassadors. This documentary was awarded and presented the documentaries in all the communities investigated in order to do so. And seeing themselves in the video or seeing someone they know was very important and listening to their comments allowed them to build the documentary with the people of the communities.

This is how APAK began to improve knowledge, equipment and quality. Since 2006, the documentary 'Bajo Sol' has been aired on television, which is very difficult because most of the Kichwa producers start on the road, but as time passes, they leave the projects behind. So the work of APAK has been very continuous with its limitations, but it has been a very rewarding job.

Today, APAK not only works with the Kichwa otavalo culture, it has an association with a Swedish organization called 'Traditions for Tomorrow', which was interested in the project and which has financed them. Thanks

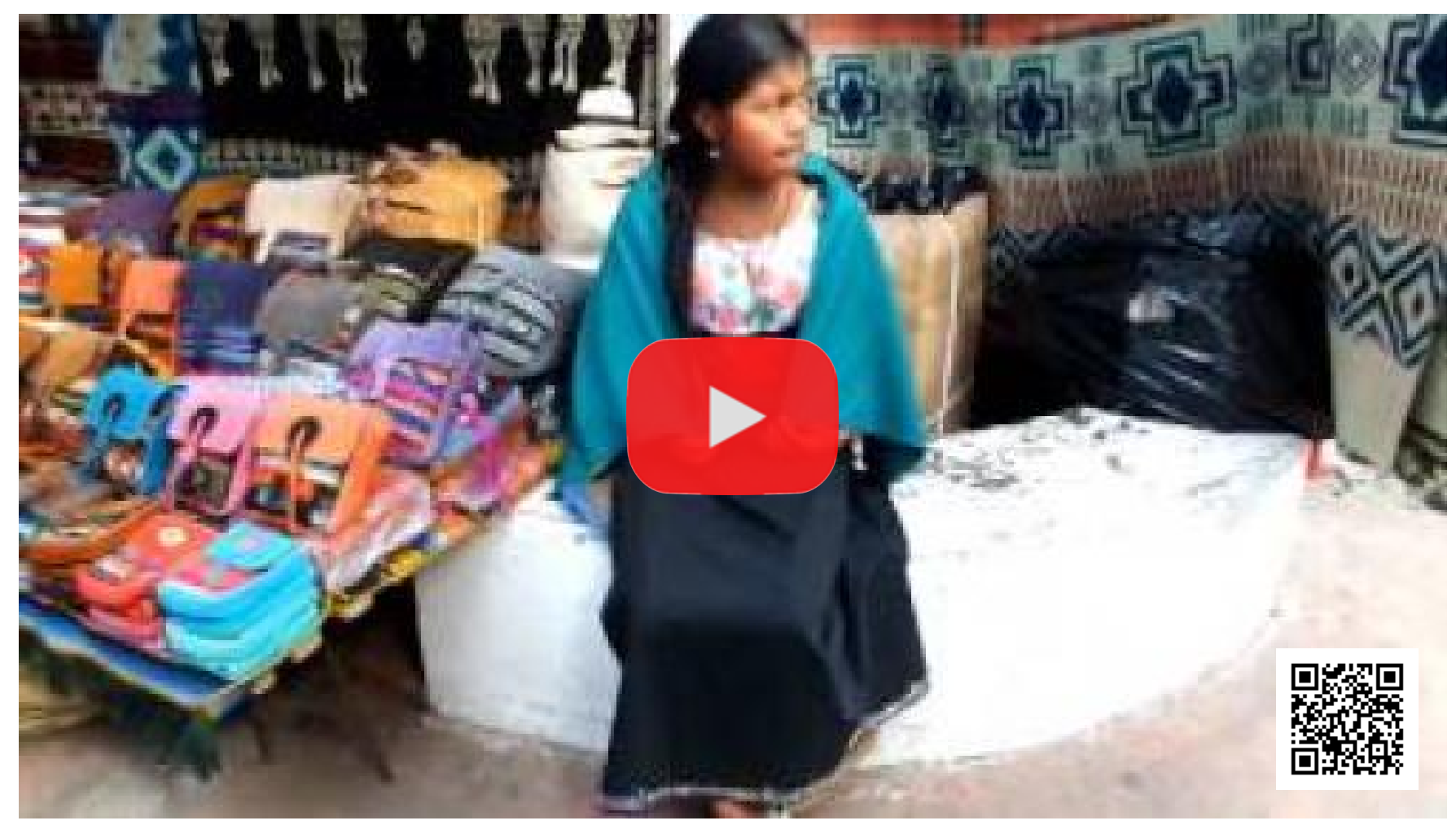


to this, APAK worked with zone 1 of Ecuador, which means not only for audiovisual work in Imbabura, but also in Carchi, Sucumbíos and Esmeraldas. APAK has given training and conferences to young people interested in this work. In the Amazon, other audiovisual organizations called APANAPS have been formed, where young Kichwa, Cofán, Siona and Secoya make videos and APAK is responsible for distributing them. APAK has alliances with Universidad Técnica del Norte and UTV, who help them broadcast the program in Imbabura, Carchi and some parts of Sucumbíos and Esmeraldas. What APAK is doing now is trying to find new alliances with new media, other channels, that also want to broadcast their program and have coverage.

Toa also explained the difficulty of finding state support and finding the space to broadcast the program on public and private television channels. She thinks that culture does not sell well in the media, so it is difficult for an independent and intercultural producer to find space. Most people like and flatter their work, but at the time of buying the program, the channels do not want it. The media do not comply with the law of $5 \%$ of independent or cultural content in its programming but seek something more profitable and easy to sell. The media tries to load viewers with incorrect content programs and eliminate the other alternative. Something that is important is that these cultures are trying to be part of the media and try to be heard, but most of the time the media and not even the State respect it.

A part of the program that APAK has called 'Under the same sun' is projected. All these productions can be found on the APAK website or on the YouTube channel. APAK activities include communication training and advice in a pluricultural context. They make documentaries, reports, short films and audiovisual content that have been awarded in Ecuador and other countries.

Toa mentioned the limitations that have been found along the way. In short, APAK is a cultural magazine that has had 13 seasons, works with cultures from the north of the country, promotes interculturality and produces all its work from an introspective perspective on culture and identity, showing these cultures not as objects but as cultures, as subjects. When they try to sell their product to other media, most of them still try to sell these cultures as exotic and everything that shows them different is not worth it. The media consider it unprofitable productions and have very few money proposals. Once they were offered $\$ 400$ for a season of 22 episodes, that did not reflect all the work involved to achieve it. In addition, most of the time the media try to design their own line of work telling them what to do and how to do it, forbidding them to represent their culture in their own way.

State institutions have talked about the need for intercultural programs in the media and have been invited to participate in forums to sell their products, but finally what the State did was create its own television program and sell it freely to the media, turning it into unfair competition. Now, APAK is part of the frequency competition and is still waiting for a result. So, what remains is to find international funds that recognize their work.

Finally, Toa finished saying that, thanks to the media, their culture and their language has been demonstrated. Before that, communication was very prestigious only for people with money, so the participation of cultures was zero. Now, with the Communication Law this has been possible. The exoticization of the Kichwa communities was and continues to be done, but now thanks to APAK their language has been more recognized and their culture has also been strengthened, strengthening their selfesteem. Although there is a law, the government does not help in its duty to create spaces for cultural media, it is not as if it prohibited these programs, but it makes the process longer.

\#PerDebate17 


\section{Conference: "The Challenges of Ethnic Diversity in Public Media"}

Bélgica is considered proof of ethnic diversity in public media. She began her career in the public media as an intern, then she was hired and started working as a reporter and then as news coordinator. Working as coordinator, she was in charge of 8 journalists, 4 in Quito and 4 in Guayaquil. He worked in Public Radio, Ecuador TV and Andes Agency. In addition, with a friend, they have been producing a program called "Ecuador Piel de Ébano", which is a radio and television program in which they do interviews about the Afro-Ecuadorian culture. Interviews about politics, social issues and about what is happening in the Ecuadorian landscape as part of this invisible mantle that has been around their culture for many years in Ecuador.

\section{When we talk about ethnic diversity, we talk about the number of cultures, nationalities or ethnic groups that live in a particular region or country.}

When we talk about ethnic diversity, we talk about the number of cultures, nationalities or ethnic groups that live in a particular region or country. Now, after that definition, Bélgica asked if there is ethnic diversity in the media. She said that after an investigation conducted in Ecuador in 2016, $50 \%$ of Ecuadorians think that the media present discriminatory content and 32\% think that television series discriminate against some ethnic groups. Now, the public media could be that change, since it allows all voices to speak and is available in $90 \%$ of the Ecuadorian territory. The public media have $77 \%$ of the cultures and nationalities, more groups of different social sectors.

It is a great opportunity offered by San Francisco University to think about the ways in which television established 


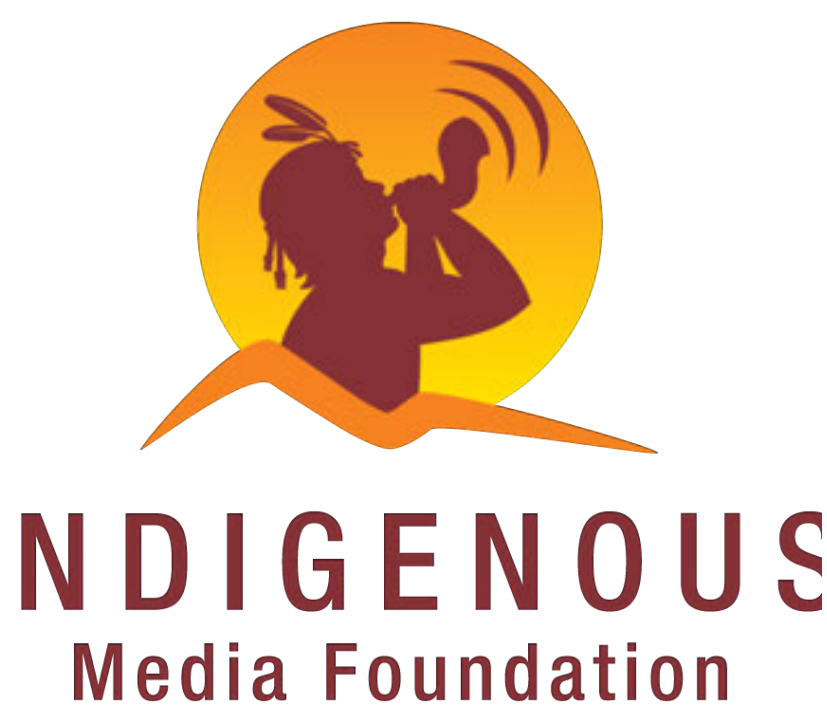

Indigenous Organizations

There are many types of organizations around the world that are actively working to demand respect for the rights of minorities in this case of indigenous groups.

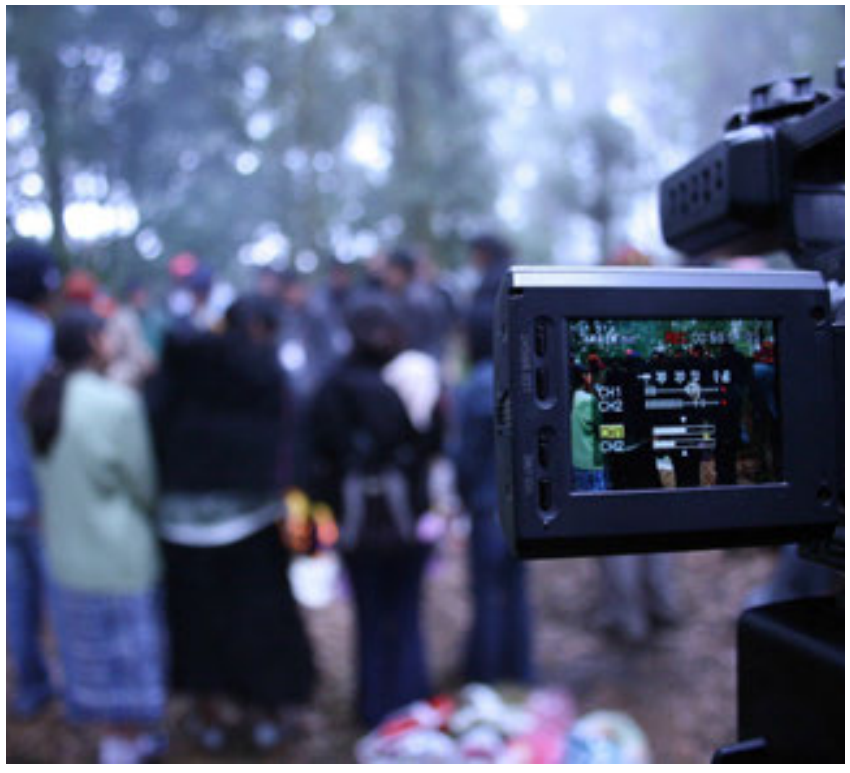

The Fight Continues

The task of communicating about important issues for indigenous communities is not an easy task since they have been oppressed for a considerable time in our current society. 
stereotypes and discrimination. Bélgica says that Ecuador is a multi-ethnic, multicultural country that has to work with all means to curb this and promote the wealth of a country, not only in economic statistics, but in the cultural diversity that can be seen on television. She said that we have to work to create this environment of acceptance of all people from all backgrounds that shape our country and our society also,

We can see this in the public media, how they work with content that reflects our country. Discrimination, prejudice, racism, xenophobia and homophobia start at an early age and public media consider children and young people to do their programs in order to eliminate these serious problems in society.

On behalf of the public media, Bélgica told us that they are aware that education and culture are fundamental tools for social change, and that they have opted for diversity and as a means of public communication, they have to be the example. They have to start this and promote all the media and society to do the same, since it is a feedback like everything we give, we receive. And if they give garbage on television, we will have society garbage, its a cycle.

Everyone in Ecuador has to do their part in order to stop discrimination, which unfortunately continues to exist in the 21st century. And to see that the public media are working with different groups of our society is something we should be proud of. And it is time for others to do the same things that have shown surprising results.

As a public medium, they reach $90 \%$ of nationalities and cultures. Everyone has their own space, their own voice and, above all, they are carrying out the Communication Law. Article 36 of the Communication Law talks

\section{There is the idea that a programmer should be part of the redaction, but the idea does not fit well yet in traditional redactions}

programs and multicultural contents. An example of this is the Afro-Ecuadorian program "Ecuador Piel de Ébano", which is a program of social, political and cultural interviews that allows the Afro-Ecuadorian population to feel represented. In the public media other groups are also presented, that is why we consider that we should all be considered in the media.

Then, Bélgica asked another question, if we think that the diversity of which she speaks is only the duty of the public media. Without a doubt, the answer is no. It is not only a duty of the public media, it is the duty of all national television media and programs to represent ethnic diversity in its contents and publications.

Bélgica believes that everyone should do this about the right to an intercultural communication. And so on, to give the space to have a program that responds to the needs of the spectators, the recognition of cultural, social, ethnic, linguistic, political, ideological diversity and religious diversity. As is well known, the Ecuadorian Constitution approved in 2008 contributes to the construction of identity and a multicultural Ecuador. The great Ecuadorian diversity is seen in so many indigenous, African or montubio collectives.

There was a strong discussion about why there are so many stereotypes in the media as women with so much make-up or with surgeries that they show themselves as a canon of beauty on tv. Now, we are breaking those prejudices and we see normal people. 
The public media only aim to comply with the law (Article 36). However, it is not enough to just accept the diversity that we have in Ecuador, it is necessary to give the people of Ecuador the opportunity to produce content in their own language, in order to express their worldview, culture, traditions and knowledge. But, here is the other side of the coin. When we talk about public media, we tend to think that it is a state media. Public media is important because it encourages debate and allows the emission of new content, new productions, new voices so that everyone has the right to express and create a greater plurality. It is important to say this to differentiate between state and public media, especially now that we have seen now that the government has interfered in public media.

When it refers to public media as an independent media, it means that it has to be separate from the government. The participation of the government in the consolidation process of these media is fundamental. The public media should be promoted by the government, but they should not interfere in the production of this, who to interview, whom not to interview or with what content this medium will work. Belgium said that the government can not interfere in the programming, can not define the production or the journalistic contents, but it should promote them. As without government, public media would not exist.

Now the public media and thanks to them, all ethnic communities and can look for the representation of cars in the media. All the media have changed the way how to write news, how to write titles and make reports where ethnic groups have more reception. Now that we have the public means to express it is necessary to have people who want to do it.

There is a shortage of afro, indigenous, montubios professionals in media. Then, the challenges are that there is a lacquer of professionals that can occupy those positions, the little or less demand of professionals can make the credibility lower, as well as the absence of opportunities in private media to comply with $5 \%$ of content intercultural These are the last questions Belgium asked. She said that there are 4 major mass media in the country, 3 private and 1 public. Of 2 private individuals there is only one Afro-Ecuadorian hostess and in the public media there are 2, so the challenges still have to be solved.

There is little demand for private media that do not comply with this $5 \%$ of multicultural content and we can also question the academy so that there are more professionals with the ability to make intercultural content. Because if we do not know how to do it, the media will not hire us, so as an academy we have to make professionals that make intercultural content.

As Afro-Ecuadorian culture, they have overcome discrimination, but Belgium, in their own experiences, explains that they have overcome discrimination, but that gender violence is beginning. In the case of women who think that they can not lead or occupy managerial positions. Then, when we believe that we have overcome something, we find another barrier. If we talk about diversity, we must emphasize the participation of groups, nationalities, adults, women, LGTI, children and young people.

Finally, Belgium invited us to build a society where discrimination does not exist, and once we stop discrimination and gender violence, we can show the diversity we want, and we need in the public media and all national television. Because if we have a prepared society, we will demand better and more quality content on television. 
Betsi Grabe,

Indiana University

Back to Index - Versión en español

\section{Keynote Conference: "Gender Coverage in the Media"}

The genre, making it clear that it recognizes that more and more it does not look like a binary. Many people today do not identify themselves throughout this binary biological separation of men and women. They experience and identify themselves on a scale somewhere between man and woman. We saw this in very nice intellect memes, shown by Betsi, and a deep and meaningful poetry. At the same time, this binary of man and woman is the basis of research on rot, which shows that there are concerns about the equality between the biological genders of people living around the world.

Grabe showed an example of the difference in the income gap. Throughout the world there is a huge disparity in large

"So, what we know is that men are more likely tan women (62\% against $38 \%$ ) to receive credits in journalism"

parts of the world. It is also clear that there is a gap in educational equality, twice as many girls as boys will never start school and that is a global statistic. It also showed some rather depressing statistics on leadership in women, and we can see that women represent a very small percentage of the government. And also, in the media world, there are some rather persistent gender differences. So, what we know is that men are more likely in $62 \%$ to $38 \%$ of women to receive credit for doing journalism. It's also interesting what women report about journalism, women do not report politics, domestic issues, world economy, but they report a lot about relatively important things like lifestyle, education or health, little of science, which is quite encouraging.

Betsi Grabe reviewed two studies she has done to understand how men and women receive news, how they process it and 
Betsi Grabe

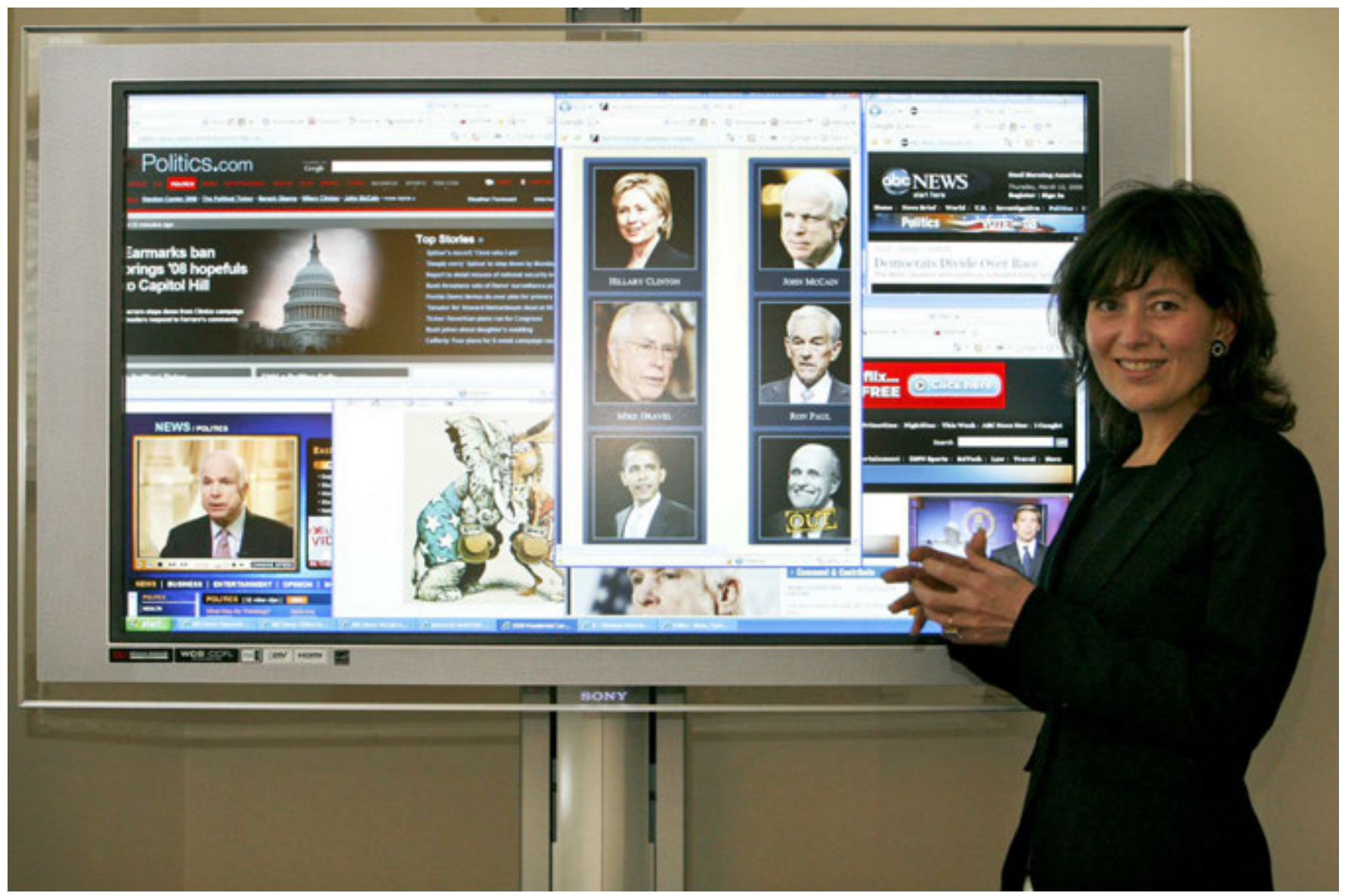

how they give meaning to social problems, and how they deal with it through media.

The first study focuses on how men, specifically, and women when they watch news and see highly sexualized female anchors and what happens to them cognitively and how they see their professionalism, etc. Traditionally women in the United States have had a very difficult time to be employed as news anchors, and what we have seen is that women who end up being news anchor their appearance, their physical appearance is quite androgynous, their hair is short, He wears jackets. And then something different happened, we began to see a great sexualization of female anchors, a lot of neckline, a lot of makeup, jewelry and part of this tradition has changed drastically in the last ten or fifteen years.

We were also able to see many women's bodies in the television news, where they
"We began to see a sexualization of female anchors"

normally use a shoulder type closely, now we see complete bodies of women, so even the stage design, the broadcast news stations have changed to reveal more women's bodies. This was something that Grabe considered important to investigate, this radical change in the way women appear in the news.

At first, it may seem like a simple matter to try to draw eyeballs on the screen and attract larger viewers and earn more advertising money. But Grabe suspected that it required more reflection, to explain what women's attractiveness is and how we can measure that and how to play it on a television newscast. 
What we know from research in evolutionary psychology is that in more than 40 countries around the world, men systematically classify women in a very clear relationship between hip and waist as sexually attractive, which means that the ratio of hip to waist It is the only predictor of a woman attracts sexual difference. It's all about the difference between a measurement of the waist and the hip, so the difference between that is a high ratio between the hip and the waist, and that's more attractive. Basically it is an apple shape vs pear shape figure. What the researchers also found, and this is quite controversial, Grabe explains, is that women who have the hourglass figure, or the pear shape, are systematically classified into a series of variables and physically healthier and also more fertile in reproductive terms. In this way, the evolutionary physiologist concludes that men somehow have this predisposition without knowing that they prefer body types in women that are better positioned for reproductive capacity.

There are two things that make it controversial. One thing is that these are very broad patterns, so they are consistent in all cultures and are also within the cultural variance. The second thing is that there are many women with appleshaped figures who have a loving husband and reproduce very well. Only to deepen a little more, to show the persistence of this relationship between the hip and the waist, even in our first cultural reproductions. Grabe showed the figures of Venus found around the world, some of them date from between 9 and 31 thousand years, we can clearly see the relationship between hip and waist in these small artifacts of female bodies. But even with a certain biological predisposition, it is clear that culture torments and reinforces this preference for a relationship between the hip and the clear waist in female bodies. It goes from these artifacts, even in Ecuador, European painting, Victorian fashion, with the help of corsets to emphasize the relations between the hip and the waist, in very extreme degrees. A practice criticized for modern fashion shows and feminist art.
Grabe recruited four hundred participating students and half of them were men and the other half were women. And he chose a student who wanted to be a journalist and presenter. And what he did was to sexualize her so lightly in one condition and desexualize her in the other condition. Even there, the difference was very small. Itall comes down to just three things changed. First, they adjusted the jacket to show the relationship between the hip and the waist, put a red lipstick and even put some jewelry, and in the other condition, she did not have any of these.

They tested people's perceptions of their professionalism, people's perception of how competent they would be to report different types of news from the war to more feminine issues such as education. They also tested the memories of people by the content of the news they present. What they found was that in the professionalism, the male participants rated the sexualized version of that presenter as much more professional than the nonsexualized one. The women participants the sexualized version as less professional.

Then, you can see the emerging gender difference. And this is quite contradictory, believes Grabe. Although men rated the sexualized presenter as more professional, they thought he was not competent to report on heavy news items or topics such as war or political reports. And finally, in memory, men could not remember much of the sexualized anchor. Men can not pay attention to the content of the news when a sexual presenter presents it.

In short, men are very affected by the sexualization of reporters and presenters. They classify sexualized presenters as more professional and, at the same time, they rate their competence in hard news content as very low and can not remember anything of what they report. The suggestions of Grabe here are 
that all women journalists or who want to be journalists would be the following. If you are interested in a long career and build your credibility as a journalist, stay away from the sexualization of your appearance, not only in the air, but in all the news.

The second study focuses on female audiences and how women process and preserve news, and Betsi Grabe in particular was interested in discovering how women respond to negative news, deeply negative news. Again we know from evolutionary psychology that we, as human beings, are what is called hard wire of negative stimuli. This is also known as the negativity bias. And the arguments are, literally, that we are born with this and it is part of our evolutionary past, so we survived as a species because we were very good at responding to the stimuli that threaten our life around us. There are two basic responses to highly negative stimuli, either focus or avoidance. And interestingly, news by definition throughout the world is negative.

The news works to a large extent as a negativity bias in humans. At the same time, we know that women report around the world that between $45 \%$ and $72 \%$ of women say they do not like news because they are very negative. We also know that this negativity bias works through gender. Women are much more sensitive to negativity, they exhibit and they avoid the answer. And this makes a lot of sense in terms of survival. The survival of children depends much more on the survival of a mother than on a father. Then, it makes sense for the woman to avoid danger. The opposite, of course, is for men, they address danger and negativity, and protect children.

Grabe was interested in testing how negativity in the news could affect men and women when they receive news. She accepted that the news was negative, but even in the most negative news there are often really positive things that journalists can focus on. An example that Betsi Grabe used was a story of the US military occupation. Astoryabout men and women who serve could focus on their daily negative description of being a soldier, or there may also be a focus between people relationships and soldiers, which is more positive.

Another example, in a story about adolescent obesity could be told a story and only focus on the negativity of the passive adolescent who feeds, or focus on some of the solutions, such as programs that involve active adolescents and together, or on stories about disasters one could simply focus on absolute devastation that is extremely negative, or one can focus on how communities come together.

Grabe conducted an experiment to see how this different framing of the news could affect men and women. He recruited 75 participants for this study, half men, half women. They took 8 inherently negative news and packaged it as if they had only negative images and descriptions, then made another version that included some positive elements and solutions. Some of the findings were excitement, a very interesting variable to know what happens in the brain, and they even had techniques to measure excitation during news viewing. The women were more excited by the positive news and the men more excited by the negative side of the news.

This is what has happened to women in this experimental study. Women are very affected by the news of more positive approaches and it is very clear that a more positive framework increases their excitement, increases their recognition memory and increases their understanding of the news. If we care about the news as a way to inform citizens of a democracy, Betsi believes that journalists should pay more attention to the ways in which they frame the news. It is evident that women would be consumers of active and happy news if the news can provide more solutions, perspectives oriented to social problems. You are not advocating good news because that will never happen, but you are asking journalists to think carefully and find positive solution elements social problems. 


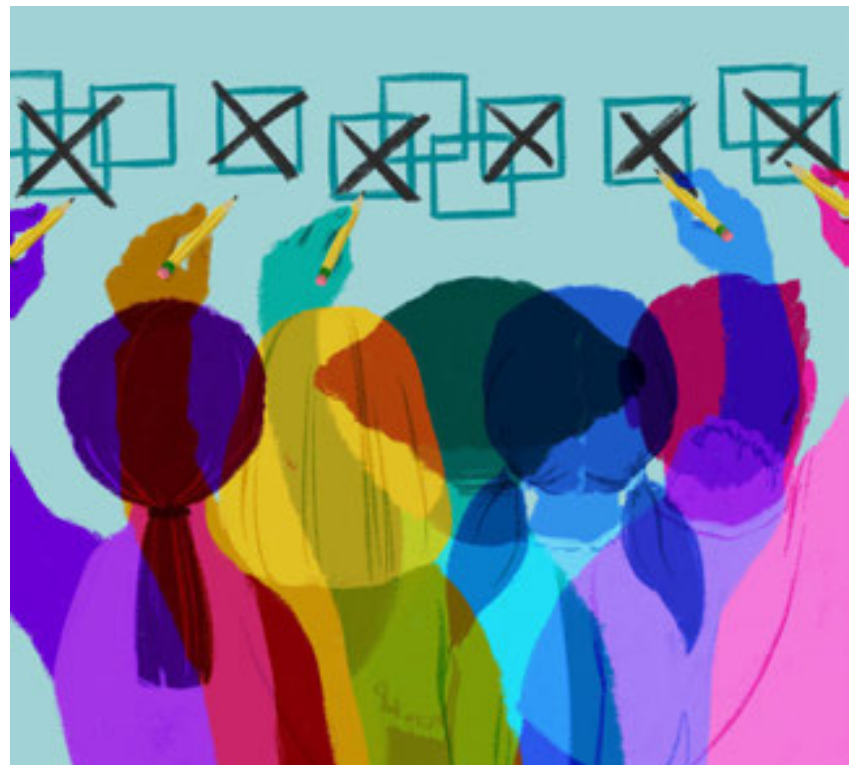

\section{A Continuous Work}

Despite the fact that women now have a greater participation in the media, the struggle for respect for their sovereignty and valorization is a matter that still needs the continuous work of certain groups.

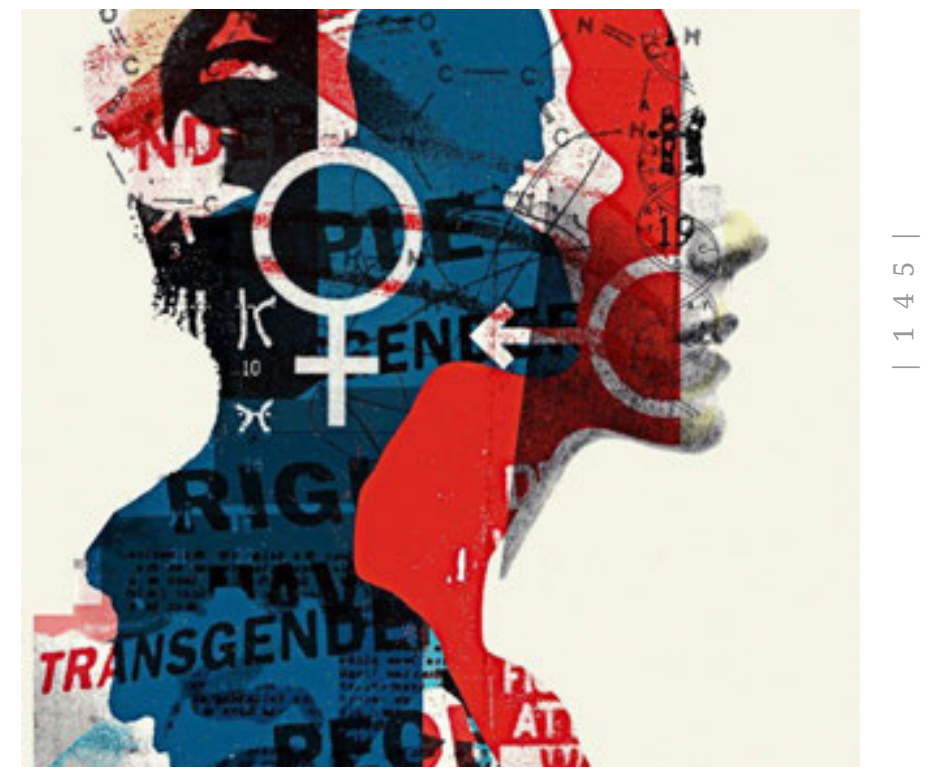

Anarchy and Freedom

What women need when their participation in media is sovereignty of decision and disengagement methods increasingly obsolete control that subtract the importance of their participation in various areas. 


\section{Forum,}

Participants: Betsi Grabe: Director of Plan V, digital magazine; Nydia Pesantez: Journalism Resea Moderator: Santiago Castellanos: COCOA Director

Back to Index - Versión en español

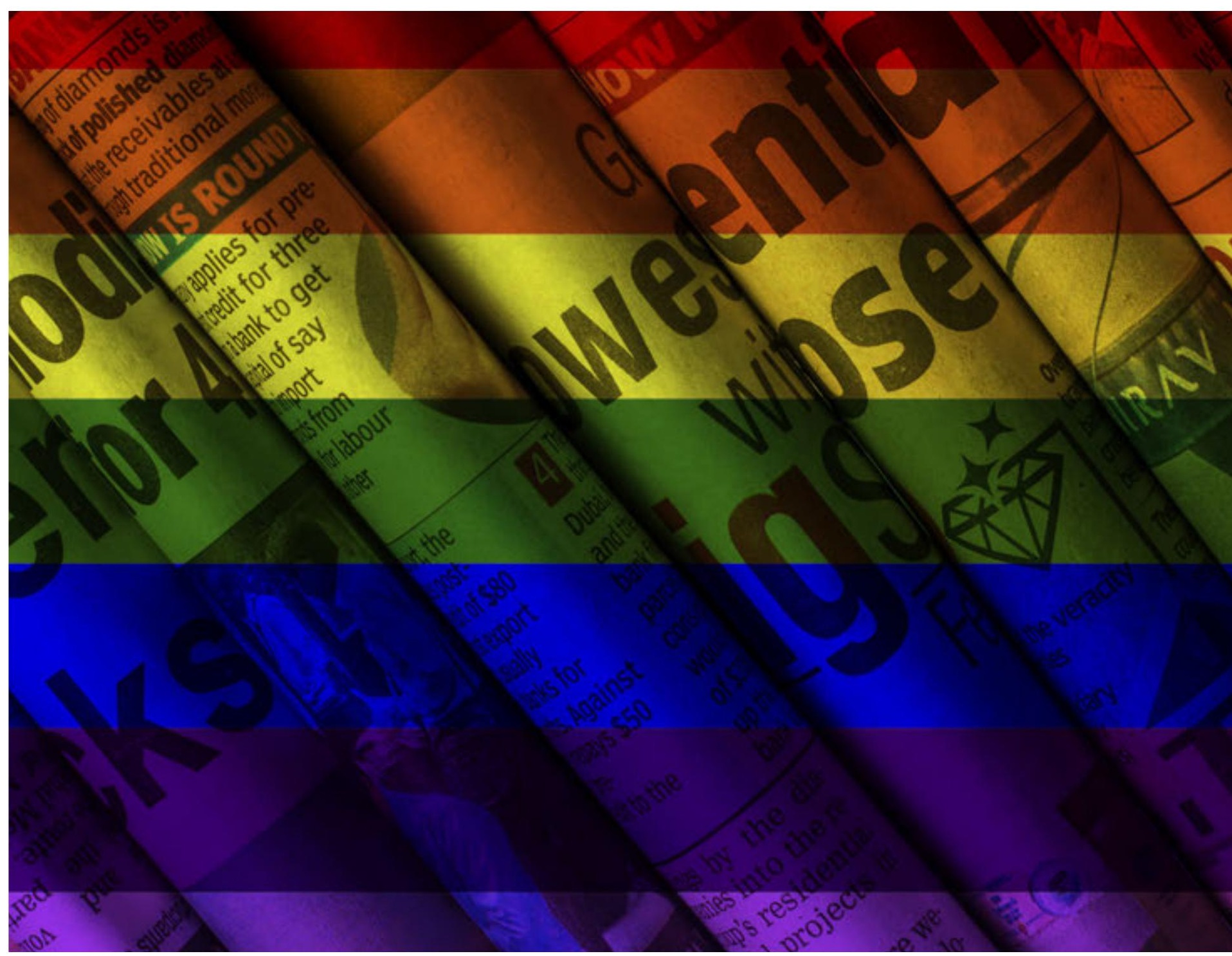




\section{"Academic Research in Gender and Media Practices"}

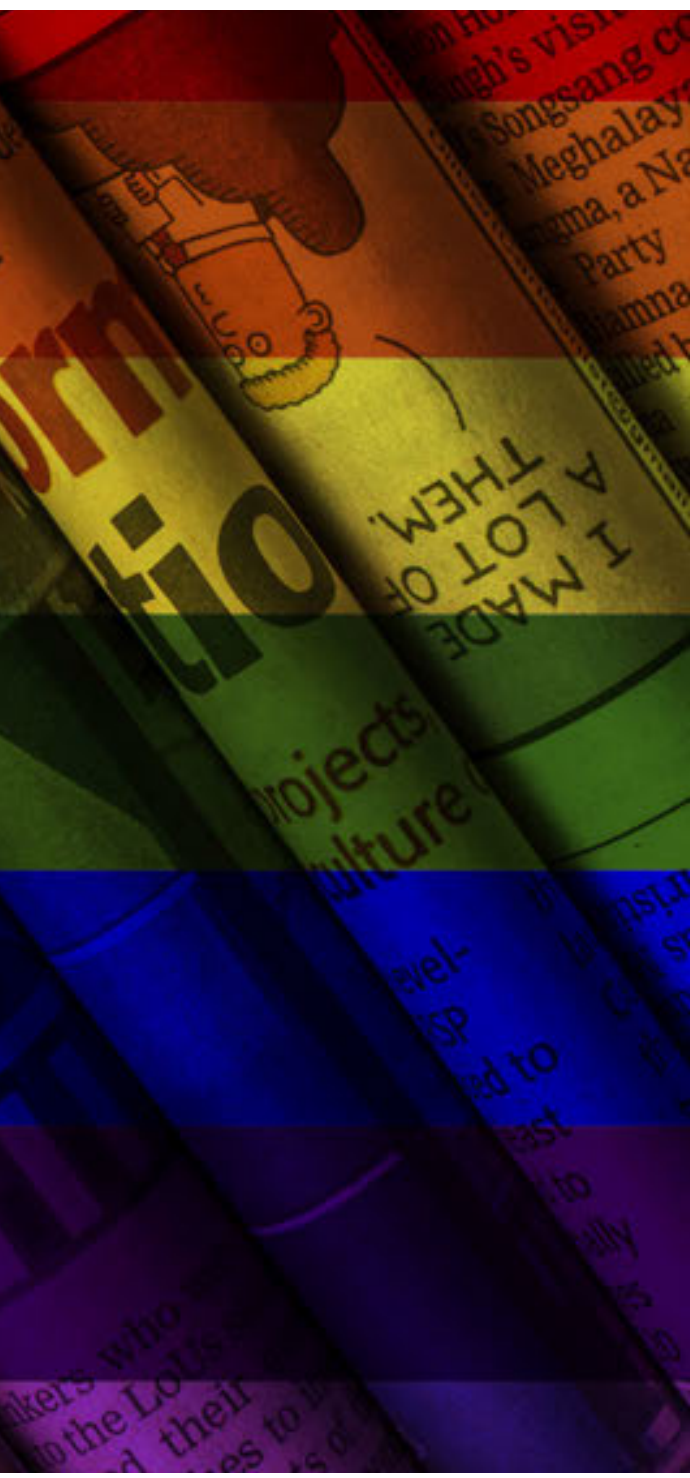

Santiago Castellanos: Betsi has already given us an overview of what is happening in the United States with the investigation with the television presenters and I would like to ask Betsi, if she has seen that in these years we have regressed Or if $\dot{i}$ something has been sexualized that was not before? Even what positive changes have you seen in gender relations in TV presenters, and I also ask ¿how do you see gender in journalism? ¿Can we start with Nydia?

Nydia Pesantez: Well, the general perception coincides with what research has found about gender relations in the media. There are some very interesting research done at international and national level. In fact, I will talk about two investigations that I have followed, one that has been under 14 years of research, called Media Monitoring, carried out by the World Association for Christian Communication and one of the Citizen Communication Observatory of Cuenca. Both make a rigorous investigation of the news, advertising and entertainment programs. In the case of the presence of women in the news, they represent $24 \%$ of the image in the news in a global number. This means that we are $50 \%$ of the population, but our presence in the media is $24 \%$, but when we talk about more specific jobs, women in the media with leadership in academia reach $11 \%$.

Taking that information made in 2015, women have not progressed. In fact, when we speak in our environment, we can say that things have already changed, and that men and women are equal opportunities. But some things have changed, now three women are talking to the dean about gender something unthinkable 30 years ago, but the heart of the problem has not yet changed. If we do the analysis and investigate the sources, we can find the evidence.

Nelly Valbuena: Indeed, I think the change has been very slow. In the field of research, we have some works that in one way or another have talked about gender, but have not 
talked about it substantially, for example, in the field of journalism. We can see some research from Mexico and Argentina on sexual diversity, but it has not become content for the media. I mean, journalists still do not talk about that and instinctively we are reproducing sources such as science, economics and politics that have been determined by $70 \%$ or $80 \%$ in masculine sources, there is more credibility in men on these issues. In the case of women, when they talk about the topics, they are asked for the most trivial things, the least important and end up talking about light topics, clothes, things that are never talked about if the source had been a man.

We are still decreasing the presence of women and the construction of things even from the source. For social and humanistic issues, we prefer to have a female source, because those topics are more about the sensitivity of women. There is a big gap between communication as an interdisciplinary field and journalism.

Betsi Grabe: I totally agree with your observations, there are so many data that support that and what worries me most is that when we see the entry level in journalism we see that many women enter journalism. In universities we see many women in journalism training and that means that something happens in the world when women go out and want to be journalists. My sense is global when women enter professional journalism and eventually disappear. With the emergence of citizen journalism, a more open news environment online, this could change slowly.

Santiago Castellanos: ¿What can be done? We can denounce it, but it seems that the old model of making news was very masculine or needed a male model in the news. So, ¿what are the possibilities of remaking the world of news in one way or another, or changing it to make more women participate and be successful? ¿What are the hopes for all the women who are here today and want to be journalists?
Nydia Pesantez: Human beings are a product of evolution, and our society with us will have to evolve. And this is the evolution of our society, the guarantee of equality. If we do not advance, the species will disappear. The possibilities are all or nothing. I have hope and I trust all possibilities because, for example, language is a product of thought or what we feel, and that language is expressed in the narrative, in art, in the way we make a news. Indeed, the mainstream of it is male, not because journalism or communication are agents of social processes, but because they are part of society.

Everything public has been built on a manly perspective because the masculine was the only thing in the public sphere. These last decades are those in which women began to make themselves public and have begun to incorporate this new perspective. Therefore, we have all the possibilities, but we have to understand that the change will not be quick, it will take time, but it does not mean that we have to overcome the flow waiting for the change to occur naturally, because it won. It will depend on us, on how much we accelerate this transformation, specifically in the media. Therefore, men and women must begin to make the change. You are the base of the change, with patience, but with all the possibilities.

Nelly Valbuena: I'm quite tired of being patient. I think that is enough and I think we still have a very strong patriarchal force in the media. I mean, the media is still obedient to a culture of patriarchy that is very difficult to transform. However, I still have hope because I do not want to be the pessimist of the forum. It is time to incorporate more communication careers with a gender focus and start to see gender violence with a different point of view. Even when we go out to do our work or when we design the topics because there is no more effective way to make the media incorporate 
this topic, I do it as a professional who proposes it. If I do not, my editor who has worked for years as a result of a patriarchy culture will not allow me to speak on the topic.

If I come with these new elements and this new vision of making news, we could start doing it. In Colombia we have this quote of Maturana, the coach of our football team said there were ways to score in some newsrooms. Therefore, I think we should score by making new proposals of topics to our editors. That work is now to be done, it is a job for the academy and the writers to propose new ideas full of knowledge about the gender approach, ethnic diversity, that we can take into account in the media agenda.

Betsi Grabe: Historically, if we follow the history of the news all over the world and I am not a historian, when I read this about how the news arrived, what we see is very persistent, that news was created by men formen. Women were excluded from the beginning. As much as new jobs as news audiences. And that has been happening for a few hundred years all over the world, so my patience is also running out. And yet, I know it will take persistence, resilience, effort to change this. And I want to say that this is not the work of women to make the change. Women need men to help them, not because they are too weak to do so, but because they must be a cross-gender effort.

When I take a look at Indiana University and look at the young people who are enrolled in our programs, I have the enormous hope that your generation will make a big difference. For some reason, you do not see this binary genre as clearly as we do and you are more fluid when you think about things, than some of us, in our generation. Therefore, I believe that, on this gender front, you are the generation that really comes forward and our patience would be worth it.

Santiago Castellanos: The next topic is something that should be there and Belgium has already helped us to mention it. She said, although there are some differences in ethnicity in the media, at least in our country. The big issue now is gender violence, so, as journalists or investigators of journalism, I was left with two important aspects to talk about, first gender violence in the workplace, but also how it is represented in the media ¿What can you tell us about that? Especially now that we have women who denounce gender-based violence in all media such as Hollywood and cinema.

Nydia Pesantez: Indeed, this covers two areas. Violence in the media, in their own work and relations between media and women journalists. This is much less reported because we have so many statistics. For example, at the UN it is much less reported that women journalists reporters men, probably because they are in a media outlet. Now, the focus of the violence has been disastrous. In this last year we have been able to see a change, but this change is not being made with a change of conscience in the work, but because a social and legal pressure and our legal framework although it supports formal equality, I mean the one written, it does not necessarily translate into real equality. One is violence and for decades the media have represented the crime against women as tabloid journalism and there are issues that do not affect public policy. They are the subjects that sell little, they are not the subjects that attack.

It is thanks to this new gender approach that we can see the changes in the media. In addition, this change has been made unfortunately thanks to the large number of victims in our country, which have awakened social and academic curiosity. At the UN, when a journalist comes with questions, they are deeper, more related to the relationships of life and power. Then, we see small changes, important changes that can set trends. Now, it is also a society's duty to demand a change in the trends, not seeing certain programs and newspapers, in the way that the media realize 
who is consuming and who does not agree with the way they represent the violence. The media must be the ones that create mass to review the content that the media offers.

There are changes in the way we approach violence, there are journalists who have begun to question this violence and criticize the system, like Roberto Aguilar, in a very frontal way. But there are some journalists who still address violence as sensational news, naturalizing this problem in the social imaginary. If you continue and ask questions: women can provoke violence and even their own death, people will answer yes, absolutely. We still think that women are owned by men as a couple or family. In our country, incest is a taboo, it is not being treated and societies tolerate it because it is said that if a father can support them and there is a man in the family, he has the right. That kind of thinking is part of the normality of our society and those are the ones that should be investigated and look for the causes of why this is still happening in the 21 st century.

Nelly Valbuena: In 2013-2014, we made abook with Humanas Corporación, Universidad Andina Simón Bolívar and the Salesiana University, as a result of a media observatory, we need observatories of gender media in a violence against women because it is the only way to know how journalism has been done We need to verify the work we are doing, we need to question it and have the elements to transform it and improve it.

In that study we could see that we have made progress in some things, that people are not using the titles of sensational news, that has changed a bit, but at the moment we review the body of the report we still see how these stereotypes are maintained to talk about this violence. And what is more serious is how this violence is justified, I mean that somehow the women were looking for that to happen, since she was the only one responsible for the death at the hands of her husband or partner of love. They made us think that the media has changed thanks to the Communication Law, here in
Ecuador. I believe that the law by itself does not make things change. Changes must be reviewed by us, journalists. For example, I was very concerned about the way the case of Karina del Pozo was discussed in the media. The press made horrors with that content, so we have to go back to the observatories as a way of transformation and change.

Betsi Grabe: There are several things that I find confusing and of great concern around the idea of gender violence and the media. If we observe different crimes in the physical world, we know that women are much less than men to become victims of violence. At the same time, women are disproportionately more vulnerable to sexual violence than men. The media pay close attention to telling stories of women as victims. And I believe that overtime makes women believe that they are weak and that, ultimately, our identity is victimhood. At the same time, I think it's very good that women are taking assault measures and exposing their victimization on social networks, I'm not saying I find a good movement.

There is another thing that also seems disturbing to me and that is if we look at the investigation on this supposed myth of rape. The research says that only a slightly higher percentage of men believe in the myth of rape than women. And the myth of rape is around the idea that when a woman says no, she really means yes. So, it is strange forme to understand how we, as women, have become believers in the myth that when we say that we do not want to say yes, I mean that it is beyond any idea, I do not understand that the research is very clear about. And, of course, I have to look at the country where I live, the United States, and look for a man who is accused of at least three violations and is now president.

And the most disturbing part of this is that if we look at the electoral behavior of women in the last election in the United States, more 
women who traditionally vote as democrats voted for Trump, than women who are traditional Republicans who vote for Clinton. Trump won because the Democratic women voted for him.

Nelly Valbuena: The media gives more importance to the victimizer than the victim. I mean, there is an excessive concern to know the nature of the victimizer as what happened to him in childhood. In Colombia we had the recent case of an architect from a well-known family who kidnapped and sexually abused a young girl and killed her. Counting the headlines that were published around the girl there was not a lot less than the one published in the whole victimizer. In addition, the media covered the identity of the victimizer, initially.

Public: We have a majority of students who are women, almost 60 or $70 \%$ of female students. being educated to be calm always. So, it's not easy.

There is an element that Paulo Freire called "The internalization of the oppressor". Where women who have not been able to open their sensitivity, their emotionality, their conscience to discover why there are differences between men and women and reach a certain point of power or the media. They do not question that, they continue their entire education process to maintain an expected position of women. Because showing a behavior different from what is expected is very difficult and hurtful. People who work in gender know it, because we have to break with family, friends and institutions to take a fight for equality. It generates intellectual and emotional ruptures, it makes us change our way of living. Therefore, it is not easy to arrive and generate changes.

\section{There is an element that Paulo Freire called "The internalization of the oppressor". Where women who have not been able to open their conscience to discover why there are differences between men and women and reach a certain point of power or the media}

That should generate a change over time. Like, for example, what Betsi talked about exaggerated clothes in women and I can barely think of more women following this thought ¿What do we need to stop that? ¿Why does it seem to continue?

Nydia Pesantez: It is not automatic. Being born women does not mean being born with gender consciousness. How to be born poor does not mean being aware of the class. Either being born Afro or indigenous does not mean having an ethnic or racial consciousness. We live in a society that since we are born, determines us. In the case of the urban and western zone, the colors, the games, the forms of upbringing are binary. For example, given that small women are told to feel a certain way or have a low voice, and in the case of sexual harassment, they ask us ¿why you did not scream? After
At one point Betsi mentioned how women need the help of men, but I would add that we, women, are already helping men to have a different way of living in their human relationships when we propose a new way of looking at ourselves, men and women.

We have taken the step to humanity to live in equality. What we ask is not help, but that they take the step for humanity to generate these changes. It is a common duty, but not a favor, a joint duty to maintain the human species. Because the way we are going is leading us to destruction and the basic foundations are the relationships of who makes the procreation of this species possible, men and women. If we do not start seeing things differently, we can not survive. We barely have 130 million years as Homo Sapiens, cosmos is 14 billion years old, Earth is 4 billion years old. We are sigh. 
While it is true that the LGBTI community has had a greater presence in society year after year, it is not surprising that many rights are still violated. That is why the performance of these people in the media is essential for the development and growth of respect and tolerance not only at a communicative level but also in society in general.

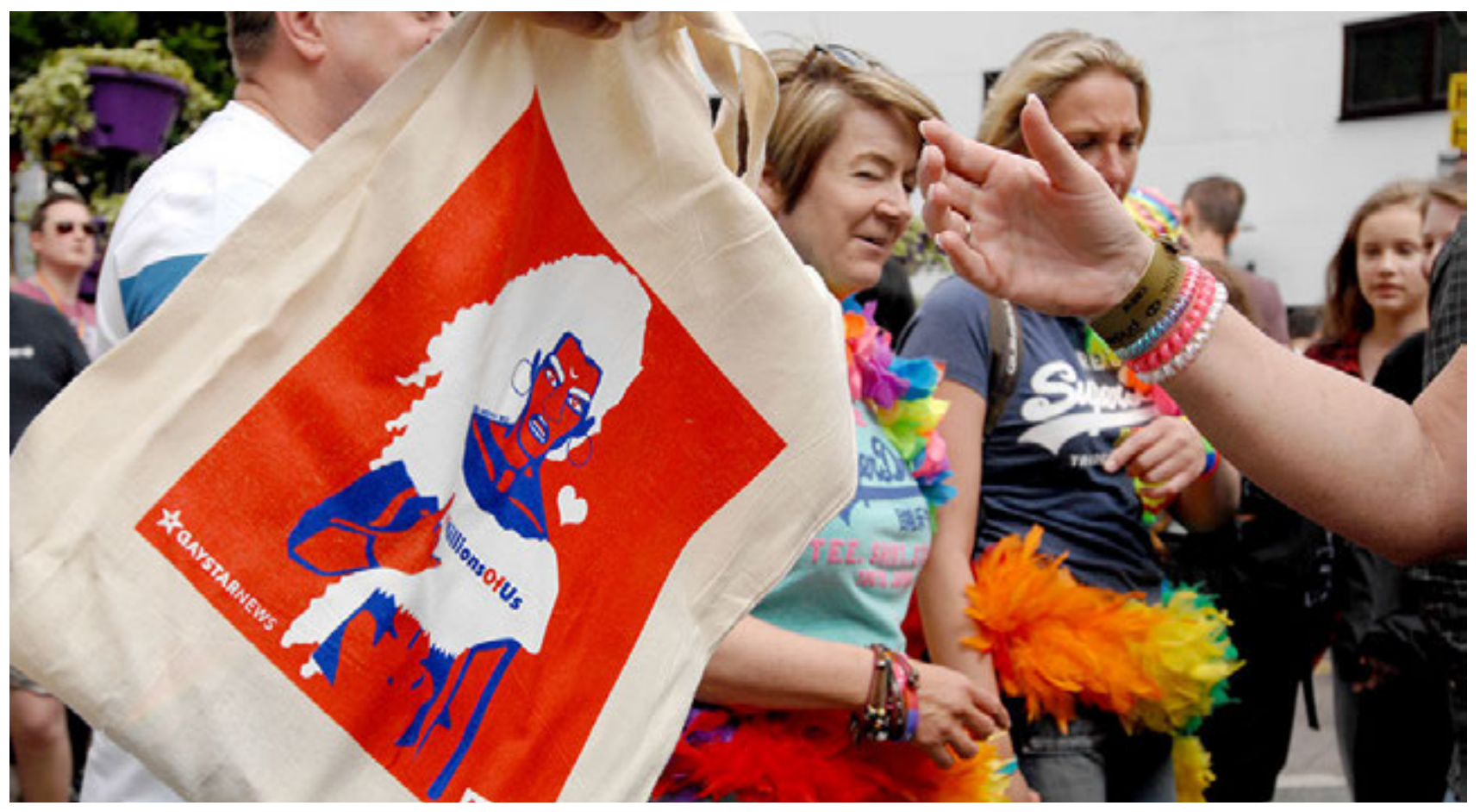

We believe that we are here forever, but it depends on us.

Nelly Valbuena: It is not new that communication careers have more women. I mean, I studied in the 80 s and we were more women than men, and our dean was a man and the academic director was a woman, the logistics positions were women, but the men were always in the positions of decision without focus of genre.

You all have a dean who has a gender focus, Eric is sensitive to gender issues, but we are not. And we did not have this discussion space and I think that's something that has changed in communication careers. And women could have more educational options. But this does not change our working conditions, we do not win like men, we do not have the same access to positions of decision and power and when we do, we are effectively women who do not have the sensitivity or gender focus and continue with these practices of patriarchy.

Therefore, it is very difficult because women have also been transformed by patriarchy and male control. We have been touched in a very complex way, the way he has made us part of this. We have changed, but there is still much to change.

Betsi Grabe: Honestly, it made me think about what you said. There is a study I have done on female political correspondents. These are women who work in the most masculinized journalistic bits. Therefore, this is a very hostile environment and very difficult to work and they are told in their interviews, it is anonymous, so I can tell you who they are, that they have to be more masculine than the guys who were working, they should literally give up being women and women in their identity and be harder and more masculine than the man with whom they worked. That's how they survive, that should not be. \#PerDebate17 
Ariel Dulitzky,

University of Texas

Back to Index - Versión en español

\section{Conference: "Empowerment and Human Rights in Ethnic Minorities"}

Ariel explained that the entire internationalsystem of human protection is based on the rule of egalitarianism and nondiscrimination recognized in the first article on the Declaration of Human Rights. This is what guides the way in which rights are interpreted. What is also important to understand is that discrimination includes all the distinction, exclusion or preference based on certain motives, be it nationality, color, political ideology, sex, sexual orientation or religion, even economic position. This aspect can not only aim to discriminate, but can be done in the search for results that may favor certain groups of people. For example, a neutral rule that can give an advantage to a specific group, such as "an exam for a job in Spanish." This may seem like an innocent rule, but it is really being a discriminating factor against people who do not speak Spanish. This is a type of discrimination that has the effect of differentiating people.

There would be no discrimination when there are not enough legislations that supports that. And the important thing in international law is that this rule of egalitarianism not only asks the State to apply anti-discrimination policies, but must apply positive policies that guarantee real equality in possibilities and opportunities. Once there is an analysis made from this point of view based on human rights, there are other important characteristics to guarantee freedom of expression in minorities, especially.

On the one hand, the entire human rights system was created around the notion of the role of the State in a paradox that influences the way we see equality. We see the State as the discriminator, but at the same time we see it as the defender of these rights. This generates a lot of tension and difficulties, especially when talking about authoritarianism in governments or dictatorships. It was possible to see domestic violence that was not involved in a human rights problem, but gradually it is considered a duty of the State to respond from a human rights perspective. Now the main debate 
between non-state actors and crimes against human rights are the big companies, the transnationals, the terrorist groups like Boko Haram that commit hundreds of human rights abuses, but they are not recognized as a State.

These dynamics have made the meaning of human rights expand through the state and not the state actors, in addition to the media. When analyzing that these private media have a human rights approach. Originally, when the declaration of human rights was drafted, human rights are considered individual rights. Some through human groups. In the case of minority rights, many of these rights are not exercised individually but collectively.

Freedom of expression as you know is recognized in article thirteen of the American Convention as an individual right, without a collective conception. The characteristic of this right is that it can not be subject to prior censorship, either directly or indirectly. Freedom of expression acts as a search to give and receive information as ideas, whether paper, written or otherwise, so all real media (internet or social networks) are also covered by these rights. Following several rules to regulate freedom and content or access to social networks. Freedom of expression is essential in the production of other rights that also have this double dimension, whether individual or social. In addition, freedom of expression is intimately related to other rights.

For example, in my own work experience, I work with people who disappear and give and receive information is an essential aspect of freedom of expression to fight against enforced disappearances. Freedom of speech, even when it is a fundamental right in the declaration of human rights, like the principle of egalitarianism and non-discrimination, must be an absolute right, for that reason impossible to eliminate or diminish. If it is not limited by the secretary or authority, but by a congressional law that follows a legitimate objective taking into account the rights of everyone, including minorities. In addition, it has to be proportional, for example, to guarantee the rights of minorities in the media, for example 23 of the 24 hours of programming of one of the private media has to be directed to minorities. This will not be a permissible goal, it has to be proportional.

In the declaration of human rights, there is a certain definition of what is considered a minority, and why is there no clear definition? Because the type of minorities we find in different parts of the world, we speak of a right that has to be applied and validated in 192 UN countries and the situation of minorities are very different. There are ethnic minorities, national minorities, linguistic, religious and none of them share characteristics. All this generates certain difficulties at the moment of defining this concept. That is why this concept is worked with objective and subjective criteria.

Minorities are defined as a group of people with a smaller number than the majority population. However, this definition has been changing and now minorities are understood as a small number of people without a dominant position in society. This change of conception of the minority occurs after the situation of the black people in South Africa, there the white minority was the one that had the dominant role in the country and the number of majority people was subordinated to white politics. So, the minority has become this term to define a group of people who do nothave predominance in the place where they live. And this in a country like Ecuador, leads us to think if indigenous groups may or may not be considered as minorities. 


\section{Forum,}

Participants: Luis Padilla and Javier Arcentales - Moderator: Bélgica Calderón

\section{"Challenges of Ethnic Diversity in the World of Journalism"}

Bélgica Calderón: We want to know what are the challenges of ethnic diversity in the world of journalism. The challenges that are to come, the challenges we now have with minorities ¿Do ethnic minorities feel represented in the traditional media or they do not?

Luis Padilla: The question is whether we feel represented in the media and speaking from the proportional point of view of the Ecuadorian population and the AfroEcuadorian populations, we are approximately $7.5 \%$ of the total Ecuadorian population. It is evident that in the media there is no representation, at least in that proportion of the Afro-Ecuadorian culture, or any other minority. There is no approach to visualize these minorities, but it is visible the exclusion of the extent to which the information of these minorities is sold, or how attractive this information is to the audience.

Bélgica Calderón: ¿How do these minorities feel represented in the traditional media or not?

Javier Arcentales: The first thing I will propose is a difficult questioning about what minority means. I think that, in this panel, it isimportant to talkaboutwhat is the meaning of minorities, because these terms give the idea of a favor, of doing a favor to a small group, for what the great group gives and takes advantage of. I think it's time to talk about different ethnic groups because I think the challenge there is to question our country as diverse, it can be ethnic, cultural. I think it's time to question this minority term. Because it is not a thing about the majority or minority, it is about rights and things change completely since that.

Speaking of representation, there is no access in the representation, but also of the visual, the way in which the diversities of image are being represented. I think that a key point in the representations of diversities is that it continues to focus on prejudice. I mean that the media often reproduces the prejudice of what is considered an Afro-Ecuadorian culture. Then, talk about representation not only in terms of democracy but also about the image of how they are being represented. Either way, from prejudice or folklore, or even from a tourist point of view how beautiful and diverse Ecuador is. So these are also wanting to reproduce stereotypes. Those are images that work to sell, but are not real. Its something that we need to get clear in order to be partials.

Bélgica Calderón: ¿Should the media produce news in ancestral languages, such as the Kichwa, or even keep the way they speak or express?

Javier Arcentales: I think so. I think the challenge of diversity because when we talk about diversity, we are not only talking about rights that are specific to each community and culture, we are talking about other groups that have their own rights. Like what happens with deaf people. 
They also need their own language to communicate ¿How to respond to the needs of all the diversities of communication? I think one of those terms is to use your own language from a very particular point of view. That is the challenge because it is not only language as an idiom, but as a cultural expression.

Luis Padilla: As Bélgica said about the need. It will be possible at least in social networks, as part of this intercultural construction of what information and ideas create. Besides the language, I will also include the dialect because, for example, in the Afro-Ecuadorian culture it is not necessary to have a language as a distinction, but there are dialects that can identify and differentiate our culture. It is not the meaning of differentiating as something bad, but as the factor that makes people understand that there are certain ways of expressing it. From them. Therefore, the challenge must also be in community radios and television channels and to what extent people of these diversities can use their own language and dialect.

A few months ago, the group "Afrodescendant Thought" presented a dictionary with AfroEcuadorian terms that shows the importance of appropriating this dialect and stop seeing it as a folklore, without speaking of it as an important form of expression and art, but as a form to exoticize our own society and its culture.

Bélgica Calderón: If I'm not wrong, a few years ago there was already news made in Kichwa at $5 \mathrm{am}$, this was suspended due to the universal language in the media. After that, the sign language also became known. Each news had its own sign translator. And another thing, let's talk about the term minorities. This group of people says that news of Kichwa was not broadcast at $7 \mathrm{pm}$ when everyone could see it. These are also a great challenge for diversity in the world of journalism. Now, ¿how can we talk about intercultural news without falling into folklore?

Luis Padilla: We have to understand that folklore is not a bad thing. But by answering the question, we can fall into some stereotypes. First, the importance is minimal in the agenda, ¿what is the importance of that content for the sponsors or the audience? ¿How profitable is that news? The challenge remembers that again and does not stigmatize culture and understand intercultural knowledge and information. We have to educate our media and the media have to educate themselves through the Internet, books, through the academy. The media must first educate themselves to educate the audience and not reproduce the stereotypes.

Javier Arcentales: Yes I agree. He will answer these questions from the lawyer's perspective and as someone who watches television every day. What really bothers me is the lack of understanding of the people who generate content about interculturality. You can listen to the "Intercultural Segment", but it is strange how interculturality is spoken there. As most of the time, this type of programs show the beautiful landscape of our country or speak about history and ancient cultures, that is shown as interculturality. I think it goesbeyond that because our institution says that interculturality is this egalitarianism and dialogue between different cultures and that supposedly aims for change. Who defines what interculturality means? The real idea of interculturality is not working yet. The media still reproduces stereotypes and reproduces those in the audience who listen and watch these programs.

Eric Samson: I just received a question. A year ago, one of my students did an intercultural research. He asked Supercom the meaning of interculturality, but no one gave him an answer. Maybe one of the problems is that there is no exact meaning of that.

Javier Arcentales: Yes, and when Supercom itself is giving criteria to sanction programs that do not find enough intercultural, it works more as an excuse to sanction. And that is one 


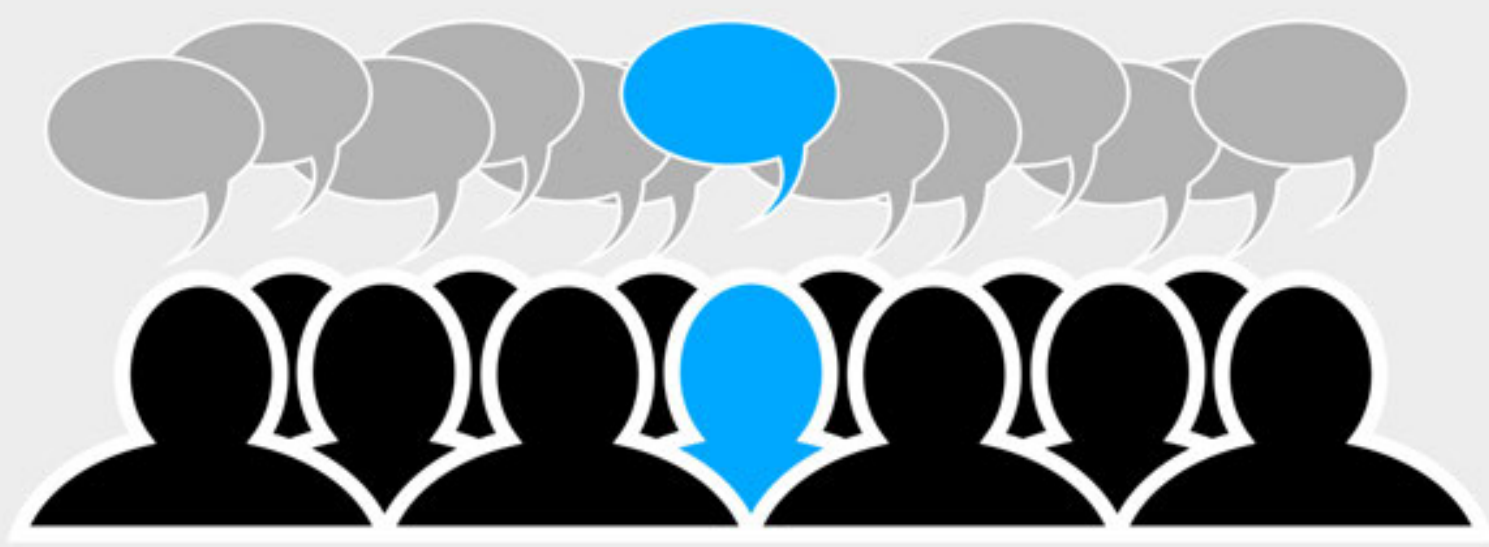

\section{Racism Blind Us}

It is important to work in a society that seeks equality through listening to people regardless of where they come from.

of the points, the problem not only in the people who generate content in the media but also in the people who create public policies to regulate this. There has not been a process to define this term, it has become a process of someone who takes a definition out of a book and applies it. The real process must be made from the reality of what people are living and from them begin to build the definition.

Eric Samson: ¿Who decides the terminology? Some of my students do not mind the word "black", others are upset and many people ask themselves. It is clear that there are some words that are pejorative, but ¿how should that process be done? What words are correct or incorrect to use? ¿Are there acceptable terms for everyone?

Luis Padilla: On that, the debate is continuous, even among Afro-Ecuadorians. The debate is whether I define myself as a black person or an Afro-Ecuadorian. The
Afro-Ecuadorian term is a builder and a word that reaffirms our society in a political way. Why political? Because it is in the constitution and in the accompanying history. Now, working with the term black and everything that goes on throughout history and the stigma that most of society has with it, means that if we want to reaffirm ourselves as blacks, a complete change in the constitution is needed. As I said before, a journalist, a communication expert who provides information, expresses concepts and analysis, must self-recognize and educate himself on these terms.

Bélgica Calderón: I think it is necessary to sit down at a work table and redesign the terms used. Because, it is not possible for some authorities to define what interculturality means without an indigenous or an AfroEcuadorian sitting at that table. That is something unthinkable that really happens. 
Like the example of the Supercom where they send their intercultural definition when there was no agreement with the intercultural societies. The same with the use of terms, it is about sitting down to decide that. I can not go to these universities and talk about how I am the first Ecuadorian black woman to speak at the UN without deciding with everyone in my own culture that black is the world with which we want to define ourselves ¿Does that term say who we are? The term black was with which history defined us, the Afro-Ecuadorian term appears in 2011.

Eric Samson: While there is this debate about the use of terms ¿What term would the media use?

Bélgica Calderón: The debate continues, but I personally consider that this duty is ours, not that of the media. If the media already opens its spaces, we have to define interculturality and how we want to be defined, appointed and even with what concepts we want to work. In addition, in the media when talking about the intercultural segment it is not necessary that it be handled by an indigenous or an AfroEcuadorian. As an example, in my case, I was hired to work in the intercultural segment because I could not be in the news since there was no news for blacks. Therefore, since it is not a novelty for black people, they told me to investigate or take something from the Internet to fill the intercultural space. But no, we Afro-Ecuadorians can generate new content and be able to be in prime time. Its all about the direction we give to it.

Javier Arcentales: In the media there is a normative framework on rights that is the Constitution, which defines these terms on Afro-Ecuadorians. That is a term that is constitutionalized and is capable of using. I think the other debate goes from the identities that each culture constructs. Some people decide to call themselves black and others do not. But in the media, I think it is necessary to verify this framework and speak with those terms.

Bélgica Calderón: Also, I think it depends a lot on the context in which the term is used. If we say black as a pejorative word, change the meaning. Continuing, ¿do you think that the media is a tool to eliminate racism?

Javier Arcentales: Surely, the construction of public opinion by the media is something real. The media works to change stereotypes, reproduce them and even create new ones. I believe that interculturality is this principle of egalitarianism that seeks to change the differences and the unfair relationships that have existed. The call of the media is how to change and put this equality in its contents. Because by reproducing these stereotypes, the public continues to believe and reproduce it as well. It is a game between the media and the public, as one that makes these contents that reproduce stereotypes and the other accepts them.

Luis Padilla: Let's not forget that we are the fourth power, so we define and build stereotypes and constructions in the audience. The media is a tool that correctly used can become tools to promote equality and interculturality, because the intercultural term eliminates racism. And there are tons of programs that only create stereotypes about the rich cultures of our Ecuador. The stereotypes that remain in us and then reproduce as hatred.

Public: ¿How or what strategies could be taken to make these intercultural programs broadcast on television? Because we know that the media tries to sell, so if the program is not sold, it will not be issued. So, ¿what strategies, we as communicators, can we use to change these?

Luis Padilla: There is something key in what you talk about economic interests. To what extent is the information being sold by the media? It is necessary that, not because it is an Afro-Ecuadorian or indigenous program, it must be of poor quality compared to the majority programs. Today, the Internet gives 
us hundreds of tools that can help us create and edit high quality videos. With a simple viral video, we can start a revolution, so about what you talked about a Kichwa program that does not sell and has to be broadcast at an inconvenient time, then that means we have to start putting these programs in other media like Facebook or Instagram.

Public: Yes, but from our point of view as a communicator ¿What strategies should we use with the media to transmit our intercultural program?

Bélgica Calderón: The environment that we find in the media is sometimes the owner of the channel that decides what or what was not issued. Now, it is important that you, as communicators, have the challenge of designing quality programs and know how to sell that idea to the owner, the news director, and convince them. Because the majority is not about the interests of the owner, but about the interests of the public. Who is watching? Who is listening? Because if we have an educated society, they will see my program, but right now, we do not have an educated society and prefer to see the best programs that we, as academic communicators, do not like. And people prefer these programs, so our challenge is not in the interests of the owner or to sell a program in Kichwa or AfroEcuadorian values, the important thing is to have a quality program and educate society to consume the good.

Javier Arcentales: Society sees these languages and dialects as an obligation, so only the media are placed in the position that just because the law obliges me, I do. And in that "I do", the media decide to do the minimum to be out of sight of the law and have no problems, which is why the media see it annoying and that is why putting news kichwa on $5 \mathrm{am}$, and that is the best example of what we do as a society. Personally, I believe that these contents should not only be made for the Kichwa or Afro-Ecuadorians, but also for those who do not belong to these cultures and who maybe interested in these programs. How a good quality program gives the call to all to be interested in Ecuador and our history.

Public: My question focuses on organizations or assemblies where there are people who represent these different cultures, but, nevertheless, these people are never interested in what is happening in their community or the problems that need to be solved. They do not know anything, but they still represent Afro-Ecuadorians or indigenous people ¿How can we deal with that?

Bélgica Calderón: At the moment there is an Afro-Ecuadorian in the Assembly, they completely forget that they are AfroEcuadorians, and that is a very sad reality. That kind of people should be responsible for the change and we, as citizens, should stop voting for people because of their appearance.

Luis Padilla: In most of the times, they know the problem, but the problem here is that their individuality affects a whole group. We are the ones who choose these people, and we have to be able to decide which people will make a real change and not forget the group behind their success. 


\section{Forum,}

Participants: Juan Pablo Rojas, Emilio Granja and Santiago Acosta

Moderator: Karina Marín

Back to Index - Versión en español

\section{"Are the Media Inclusive?"}

Karina Marín: ¿Has there been representation of marginal groups thanks to the Communication Law?

Santiago Acosta: The subject of the Communication Law is very complex. I think it has a very good part that allows you to reach new topics, especially intercultural, but making it a reality in the media is the most difficult part. This implies how reflection is created in the media, be it a television or radio channel, to include different groups. And it is a step that we are still taking and that will surely take a long time to change all those who work in the media.

Emilio Granja: It is very complex to include minorities in the media because they are all different. For example, with disabilities, it is necessary to change the environment for them and adapt it and have a little patience since not everyone has the same rhythm. It is much more than laboriously including them or giving them a job because of their disability, so I agree with you, since I believe that there is still a lot to do and we have to continue giving spaces to continue growing.

Juan Pablo Rojas: It is important to recognize the context, before this law there was only a very ambiguous regulation that, basically, was the National Telecommunications Council that controls the contents, so basically there was no regulator, since there was no content control. However, I believe that this Law of Organic Communication came to establish some rules in the world of communication, but the issue there is that the provision of the law that required the inclusion of certain groups was too difficult. I do not mean that they were forced, but they did it quickly when the media was not ready for something like that. That makes me share the same criteria with my colleagues because in reality it has been very complex to equate the Communication Law, its provisions with the media.

There is indeed a before and after, and for now, I think that, from my experience, there is a great attempt to reach those provisions and there are many ways in which the media have become inclusive, maybe later we can talk about Ecuavisa, experience that is very interesting.

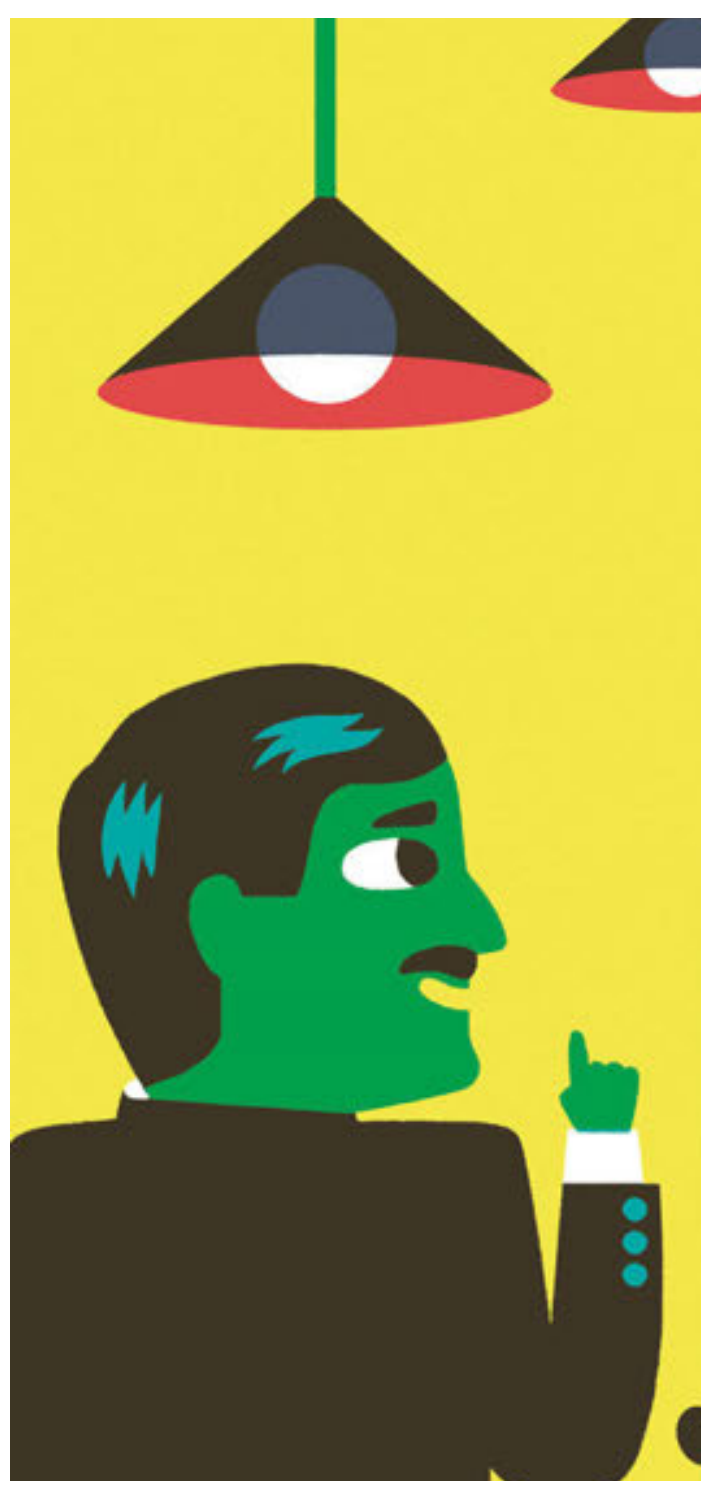




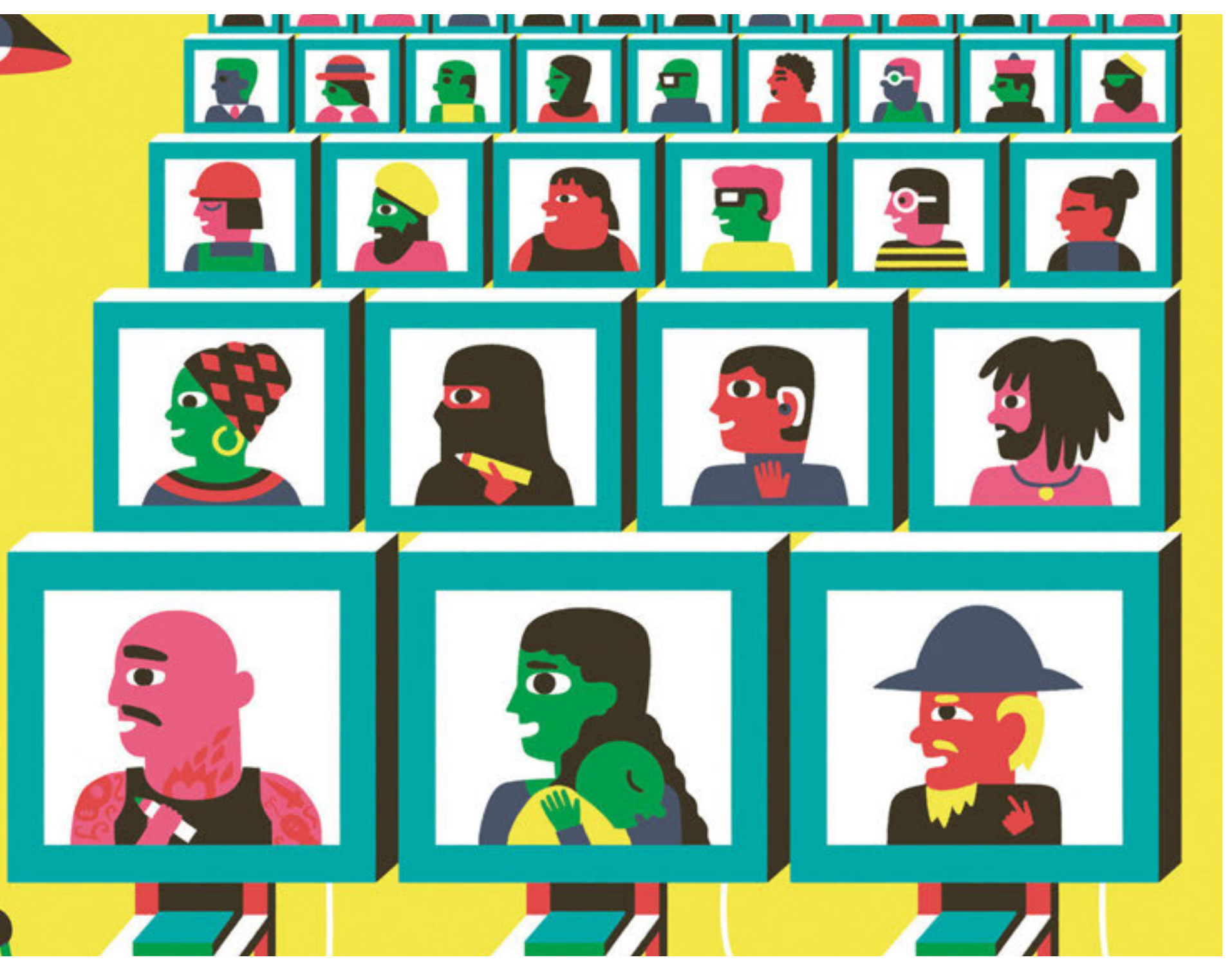


Karina Marín: The inclusion, this concept has been much questioned since it is considered a minority necessarily included in the institution, we can call it media. And the real ideas are that movement to be mutual, then that is already a problem. We talk about inclusion, we idealize and that ends up being an empty concept. But the concept, I care more in this question, is the representation. Because thanks to the Communication Law we have been able to represent some group. I think disabilities have always been represented, not that this has started now, it has always been there. Now, the problem is ¿how has it been represented? That is my question, so we have to ask ourselves if the Communication Law has questioned this representation of disability.

¿Where are we representing disability? ¿What discourses continue, which are questioned? And the next question is whether the media is exist. And it is very sad when you want to invite the best journalists to workshops to reflect on disabilities or interculturality, journalists simply do not go, do not want to go. We have to generate spaces where the media, society, universities and communities continually talk about this. I think that is the best exercise we can do.

Emilio Granja: I would like to talk about an example of your blog Karina. In an episode of "Castigo Divino", Jorge Ortiz spoke of Lenin Moreno using aggressive terms. I think that represents our society, how we treat people with disabilities. And if you think about this journalist in the position of power he is in and has been seen by so many people on television, everyone would think that it is right to treat people like that and that says a lot about our society. When we represent people with disabilities, we stay up to the positive image and do not talk about more problems

\section{There are works that Ecuavisa has done in 2014 and 2015 in respect to putting authority, vulnerable groups and journalists on the table and jointly talking about this issue}

a reflection of society for vulnerable groups of people.

Santiago Acosta: Not necessarily, I think it's a very strong idealization to say that. Each medium has its own differences, and I would talk about the example of Ecuavisa. Two years ago, we did some work to talk about these issues and it was a very positive experience in Quito and Guayaquil. With the Ombudsman's Office we have done in the last 4 years a lot of workshops with more than 800 journalists from all over the country talking about these issues, and we use the Ecuavisa example.

The media sometimes have very difficult economic situations. The discussion space where we can talk about this issue does not they may have, even though people with disabilities have problems like any other person. I do not think that is enough when talking about disabilities.

Juan Pablo Rojas: I think that answering that question positively is presenting some criteria that may not be what we are looking for because there is a wide variety of media and that may not mean that they are the reflection of your audience. Infact, the work that Ecuavisa has done in 2014 and 2015 with respect to putting authority, vulnerable groups and journalists on the table and jointly talking about this issue. We had the channel owner sitting next to the producer, the editors, activists and even children in many rounds of workshops that practically lasted two years. 
And why? Because we needed to collect the information and educate the people.

I invite everyone to access this document that we publish after this work, it is a public document and, at the beginning, we invite all the media to be part of this. I clearly remember that the state channel was there, but it did not finish the job. Finally, after having made this document we share it with more channels and even some organizations. Therefore, our reference is the Communication Law, but our foundation has been made by ourselves, the construction of dialogues, in the forum with citizen participation, which left us with very enriching thoughts and experiences, like what to say, what that does not mean, how to represent or how not to represent.

Karina Marín: I just remembered that text that I wrote about "Castigo Divino" and I want to say something that in that case I specifically mentioned. At that time, two emblematic journalists in Ecuador, Janet Hinostrosa and Jorge Ortiz, used aggressive terms to diminish the current president. What was worth noting was the paradox and it was that ten years after announcing that this country is living inclusion, our own presidential candidate was excluded from the language and that can only be the demonstration that ambiguous public policies do not go beyond the superficial and I think that, in part, that is what the media represents in the rest of society ¿Are the media key to transmit a message that can change the perception that society has about marginal groups?

Santiago Acosta: Obviously we are the multipliers of opinion. For us it is vital which means we always use, a very practical example, if you are a mother and listen to some news that you share with your family. If you have a store, you would talk to your customers. If you are a priest, you will talk to the number of people who go to church. A means of communication can reach thousands. We had a case in Puyo, how a journalist talked about false news on the Internet, took the news and published and it turned out that in Puyo everyone believes it to be true. The media have a key role in this and in the person who works in it, the people who generate this information and programs are the people who need the most continuous training. The example he used of "Divine Punishment" and the terminology used. A journalist and scriptwriter must know how to use words respecting rights.

Emilio Granja: The media is important at the moment of transmitting a message, like speaking in terminology and it is common to hear the word "special abilities" and it is not true because people with special abilities are superheroes and I do not consider myself a Batman who would solve crimes tomorrow, so I do not think they are correct terms. Not even different skills. That person is someone who does the same thing to you in a different way and there is nothing different with someone who has a disability.

I believe that many people are wrong at the moment of transmitting the message or trying to label someone so as not to hurt them. In that way we victimize the person that the media wants to avoid. But yes, I believe that the media is the key to transmit messages. We need to include more people with disabilities and make more content to help them.

Juan Pablo Rojas:The media educate, of course, but they also inform and entertain. How to do it? It is the basic information that we have to keep in mind at the moment to prepare a report or transmit a content that will educate the audience and will surely be entertained, because to entertain oneself as such, anyone can do it. That's why we have parameters and codes to do it. We have to consider that as the dynamics of the media, because they exist, and they do it for 24 hours. There are other media that have content to entertain, information and the important thing is that the audience chooses what to watch. The important thing is that a State does not tell you what to look at. In any case, I think 
the media has a very important role in the function, whether traditional or digital.

Karina Marín: First, the terminology, one listens to certain journalists talking and they go around to say the obvious, how to try to be politically correct, and this can end up in very bad situations. I do not know if you know that last year was 10 years of the UN declaration for the rights of persons with disabilities, Ecuador signed that declaration in 2008, so next year, it will be 10 years since Ecuador committed to this declaration .

The whole statement is outside of some basic principles of disability, it has nothing to do with the human being itself. The disability is a concept that speaks of the circumstance of a particular person, whether physical, biological, mental, sensitive or spoken, when seen in a society that does not allow access to the egalitarian conditions. That is a disability. So, l, who am the mother of a child with a disability, say that I also have a disability, because society does not allow me to have the same conditions with my son in those places. And you (Emilio) is a person with disabilities to the extent that you can always find obstacles to access the conditions of egalitarianism.

This is very evident that at least the media ignore that it is a triumph a fight that began in the $60 \mathrm{~s}$ in the United States and Europe, specifically in England, which promoted the social model of disabilities. And what this model does is react against the medical model of disability, I mean that we are not subject to the disease of piety. We are subjects of rights and that vision, the discussion has to change. Apparently, we know nothing of this revolution that began in the $60 \mathrm{~s}$ in this world with the slogan "Nothing about us, withoutus".

I invite you to know, because I believe that any communicator can do their work without knowing the declaration of the human rights of people with disabilities, as well as the declaration of LGBTI rights, etc. It is very important because that is the center of important debates around these issues
¿Would any of you want to talk about this?

Santiago Acosta: The issue of disability, I think, is a good way to talk about human rights. There is one thing we always talk to anyone who receives training or education about rights across the country. When you put on the glasses of human rights, you begin to see the word in a different way. You start to see the contents of the media in a different way. I will remember a meeting with the people of Vivos before it stopped broadcasting. One of the writers told us that he has many gay friends and we ask him why he is stereotyping them. It was a very long meeting, approximately 6 hours. And in the end, we had the problem that they had not had the opportunity to use these human rights lenses, which is one of the vital things to be able to understand this.

We remember some occasions in which people begin to see new things and can understand what happens in the media. This works for journalists, producers, musicians, lawyers and this changes the life. It is essential

Emilio Granja: I think the media has failed to show these rights when they represent a person with a disability because, as I said, we are still the image of compassion. I have not seen how difficult it is to take my card here, how difficult it is to go to the doctor or wait for the teacher to place it in a higher or lower grade. Even, how Aneta does not have a car for people with disabilities to learn to drive and I do not see journalists talking about this. So, yes, I think we need spaces, but we also need more. For example, in labor inclusion. Most companies give work to a person with a disability because they have that space, not because the CV has impressed them. I think the media has failed and is still failing to explain that part of the disability.

Juan Pablo Rojas: Breaking structures is very complicated, but not impossible. We have 
held workshops and conferences, but he has not stayed there. We have a very close relationship between the CONADIS that have taught us about terminology, what to say or not. And I have to say that in that practice people were starting to know about this, so that worried us a lot because basically they are the ones who share content, but without a filter or knowledge. We realize that we make big mistakes. We have had many CONADIS workshops in the channel because we consider it important, because we believe that Ecuavisa has a very important social responsibility with its public.

We have a law that verifies everything we do, but we do not have the need to change things. If you now look at Ecuavisa, you will see a very responsible, more inclusive programming and visualizing things that we did not have before and some filters. All our content before being issued is approved by a jurisdiction.

Public: I want to ask you what conclusions you have about working with the channel and the workshops within your work team.

Juan Pablo Rojas: Two things, unlearning and then realizing that the wrong people about communication were happening, was one of the most important conclusions for us and for that we did everything possible for this workshop and then we received the internal comments we had. And it has not stopped from there, we continue learning, giving lectures. This experience leads us to have a more responsible programming and to be more human.

Karina Marín: This tendency to speak like the superhero and do admirable things and talk about the poor who live in the worst situations. There is also the place of the superhuman or subhuman for people with disabilities, but we never leave them in between. Within the themes, activists have been talking, it is the right for sexual assistance for people with disabilities, and here people die with that, it is a taboo subject. However, it is time to talk about it because if we do not keep looking at people with disabilities, like angels and angels, they are asexual, and it is very wrong to think like that.

Public: Within what public media works in inclusive communication. Santiago spoke about communication with rights. I would like to know, from Santiago's own experience, what are the negative things and how do you get people to see things not as a taboo but as a topic of debate.

Santiago Acosta: Reflecting on communication with a rights-based approach is not a priority in the budget. Not from the institution, but when it can make a big rapprochement in the national interest, it can not, economically. My experience during these years is that it has created some other alternatives. These issues begin with activism and the effort made by government authorities, civil society or universities. Talking about this in universities is vital because the professional that would be in the next 10 or 20 years, the content that your children would consume would do it.

There is the possibility of a historical rupture of Facebook and Twitter that appeared 10 years ago, this development of new media can improve our society with a new wave of thinking about rights, not only about disabilities, but also about women, people elderly and LGBT communities. They are reflection groups that go around these new means of communication and can help us to develop a new society and if we do not take advantage of these years, it could even get worse.

Emilio Granja: Part of this is also important to highlight the work of journalists with disabilities. There is the case of a journalist who has a visual disability who for twelve years has worked selling candy on buses and with the labor law found a job in state media. Then, there are positive things that will begin to develop more and more in all media 
And that's important because I'm not the one who goes out looking for a job, I think there will be more and more people with disabilities who want to have a job, not only in journalism, but in other careers. It is also part of the inclusion because we still think that people with disabilities can not do the job of a journalist, but we can, there is no proof that it can not be done. That's why I think it's necessary to have a visible face since a disabled TV presenter would help encourage other people with disabilities to do the same.

Public: I had the opportunity to work with Maria in El Comercio, who is a journalist with a disability and, in a talk, she told us that she does not want people to pity her, that she is a good journalist, however, I met other people. This speaks of the lack of opportunities and of not having physical justice. For me it is very complicated to talk about this topic because it depends on each person. So, I ask you, does it depend on each person or is it a standardized topic and ¿how to talk about and deal with this issue?

Karina Marín: ¿Do you mean more to the terminology? It is interesting because at this moment l am in a personal debate on this topic, because for a while l adopted the terminology used in Spain that speaks of people with functional diversity or people of the diversity function because it shows that we all work in different ways. Some see, others do not, some communicate differently. But lately with some readings I've been doing, I started to question whether this terminology is not like I say you're different, different. And we come back from a world of power to diminish someone. Then, the diverse topic begins to rebel in my head and, sometimes, I prefer to use, even in a political way, the disabilities ¿Why? Because when you say that a person has a skill from the beginning of his life, you say he is capable. And did a person with a disability call them incapable? No ¿What would be the opposite of people with disabilities? And if you are a capable person, it means that someone qualifies you for that.

Then, when I am disabled, someone else is sorting. A society that does not give me enough opportunities for equality. This discussion, we will continue having it, but the important thing is to discuss and create spaces to talk about these things, we need the debate, we need the discussion. We need to hear them tell us how they would like to be called and explain themselves. It is them we must listen to.

Santiago Acosta: The virtue that language has is that it continues to change through time. Activism from the 60s until now, has allowed us to evolve in a series of terminologies and words that are valuable to us. These opportunities offered by history, at least since 2000 in Ecuador, have allowed the search for new words and meanings for the terminologies that define different groups of people. You mentioned the case of Afro-Ecuadorians. In the office we work with an Afro-Ecuadorian and it is a pleasure to work with her, as a pride for the office. Making this topic attractive to the news is practically impossible.I remember that the first year we celebrated this was in 2012 and we held a press conference in which two media attended.

The language has to go along with the actions and actions throughout the reflections. That is why it is necessary that at the moment we work with the media or the universities that prepare the journalists of the future, know how important these things are. In 5 years maybe, we could see these new journalists promoting inclusive news. These are some issues. I would use an example that we had with a collective with whom we work. The short people, if we have an association, one of them told us that they want to get on the bus. It is still talking about this in the government or the authorities, but nobody has dared to give a solution as a public policy for buses to have an extra step, or look for new regulations.

Language, action and reflection must be taken by the hand. If we only look for the language, 
things will not work. The multiplying role that the media have is to hang a massive reflection for people. A blog, a Facebook page has thousands of followers, could we have a page talking about these topics with the same number of followers? That is a communication challenge. How we bring these issues to mass communication.

Public: I just wanted to ask about parody, because entertainment is also an important part of the media. My question is ¿what standard is there to make satire or parody on these issues? What is good, what is wrong?

Karina Marín: Once I wrote an article on my blog about a joke made by former President Correa because he referred to the player of the Barcelona football team as disabled. So, I talked about this use of humor, a mood spoiled by our current president. And I was waiting for Moreno to react, and he just laughed. So, all I can say about this is that the satire and parody in the world we live in make sense if they have a strong political content and if the purpose of using sarcasm is to provoke even violent, even aggressive, reflections in society. If it's about diminishing someone, it does not work.

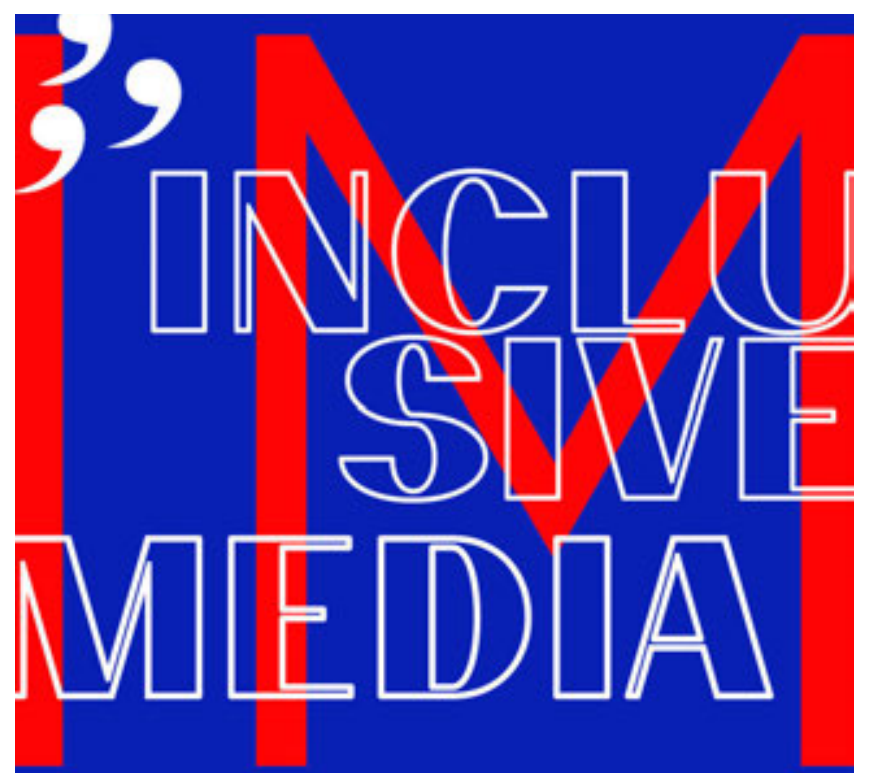

Emilio Granja: I think the problem is society. Because, for example, if you go to a food court and see a person with a disability to walk and the tables that are closest to where you buy food are being used and nobody intends to stand up and give space. You can not be aware that way, society does not do it. And I already talked about this when saying that the media has failed to find and say that there are more problems for people with disabilities. We do not talk about that because, as Karina says, we can not be politically correct. In addition, the news is $90 \%$ bad news and the media prefer to have what is left to give a positive message to people with disabilities. And I hope that in the future there will be spaces specialized in this topic because I do not believe that traditional means suppose it.

Eric Samson: And I hope those spaces are built by people like you. We hope that the web page of your thesis can continue working with Ecuavisa and that all teachers are concerned that people do not allow this to happen. He will graduate in a few months, having taken the same courses as his colleagues, doing the same job and hopefully find a job as fast as everyone else. Because you deserve it.

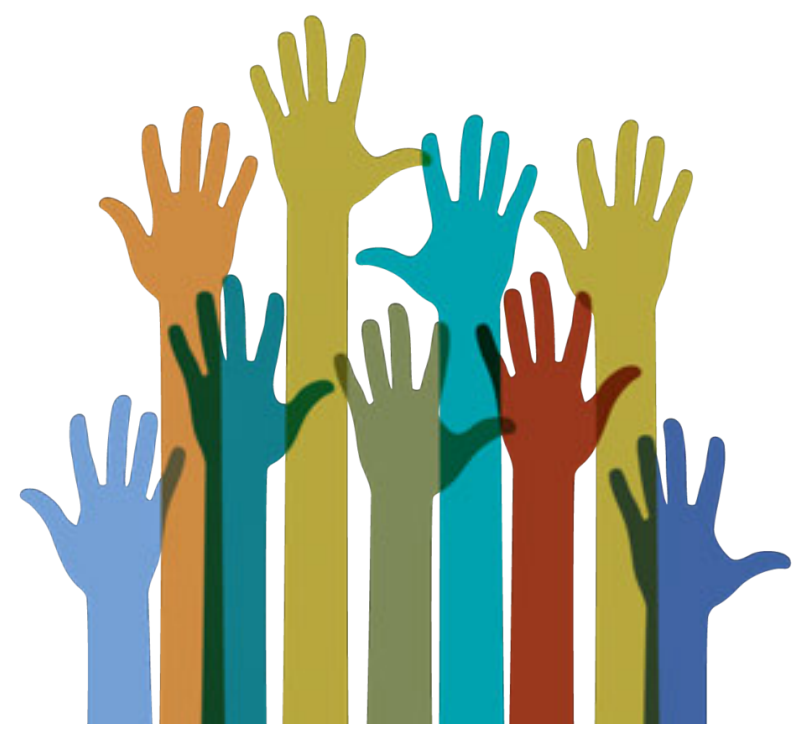




\section{Day03}

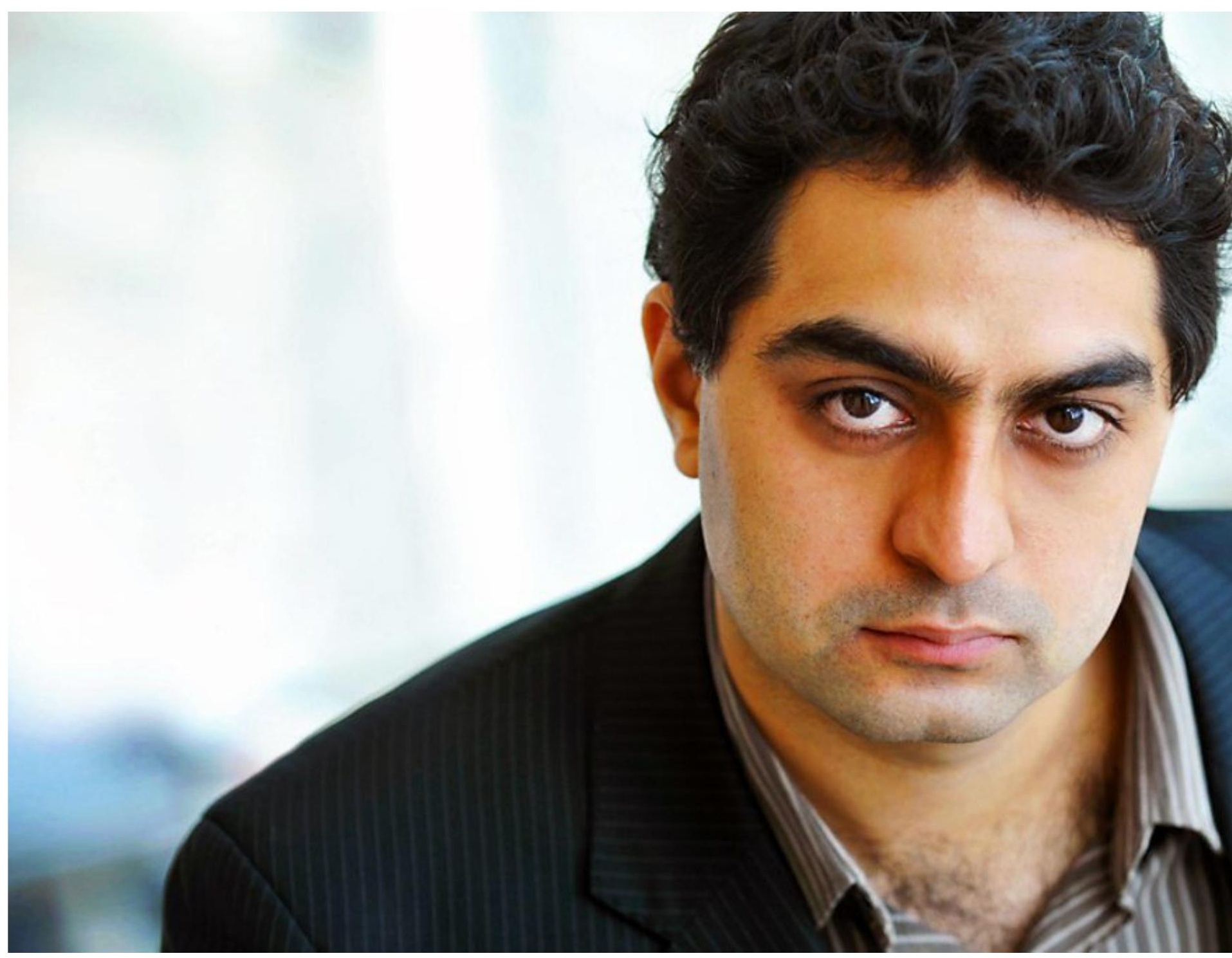




\section{Keynote Conference: "From Social Networks to News"}

Mukul Devichand told us two stories and both stories of new units he has created on the BBC. Each story symbolizes different stories of how journalism responds to one of the greatest challenges of our time, which is the domain of social networks. Then, first he asked who in the audience receives the news not from the newspaper, but from the social networks. All over the world, the statistic is that many countries, their proportions of adults who receive their news through Facebook are now 50\%. He showed us a frog and an emoji.

$¿$ Do you think newspaper editors think it's a light place and do not give them enough resources to cover it? Traditional publishers ruled out the amount of quality journalism they

\section{The night of the elections, France had an immediate blackout in the media and this was precisely the moment when Macron's leaks began.}

can do on social media. He started with the frog. The frog symbolizes how BBC Trending reports. He showed an image of Emmanuel Macron, president of France, won against his competitor and it was a very closed race due to social networks. A hashtag marked a trend with the name \#MacronLeaks, which was a number of leaks from your email. There was nothing really bad about these leaks, but I had a tendency like crazy, seemed angry and bad, and did not do well. Publishers struggle to report this for many reasons. This is how BBC Trending reported that story.

Thenight of the elections, France had an immediate blackout in the media and this was precisely the moment when Macron's leaks began. His team of jorunalist 
investigated how itbegan. Because that's what they do, they research the internet. Then, they discovered that those leaks started at 7 p.m., they really do not know who put them there, some security experts blamed the hackers related to the Kremlin, others thought it was a lone wolf. But the frog appears in a crucial question. What is the way in which this news was disseminated? His journalist posted on the Internet and discovered that in one unit there were right-wing groups that identified themselves in the four channels. These guys were not in France, but in the USA. UU., But they spread these leaks. And you can say it because of the frog. They use the frog as their avatar in social networks. Pepe is a very pretty frog, but now it has become a symbol of global fascism. The hashtag itself started at 8 p.m. by another person who was not in France. It also needs to be said that Wikileaks helped amplify this trend online. So, the point that Devichand tries to make here is that each hashtag, each video on YouTube, on Facebook represents and agenda. If you are a good journalist, you are always looking for agendas. The agendas of social networks could be good, bad or you would not like them. The point is that they are properly investigated, the full force of the BBC's journalism, so this was for the extreme right in the United States and this is what they achieve. By working together in this coordinated way, hackers and the American right manage to break the immediate blackout in France.

Macron Leaks had a worldwide trend and in France, and French newspapers, radio and television stations had to report in some way. The moral of the story for journalists. Social networks are a place we must understand, we have to inform with all the strength of our journalism and, when we do, the social networks themselves reward us by sending us clicks. That's the trending story of BBC.

He showed us another example of how they help the public understand memes. So, the way we tell stories is also different. When you inform on social networks, you can not do it as if it were the news of the night. Their videos reflect a new tone, they are not like the normal reports of the $B B C$, they are for the online audience. It's all about tone, if you spend enough time on social networks you can say that the way you tell the story and the interest are different. They must be deeper or richer or more significant from the editorial point of view.

Social networks are interesting because they show us how much people value emotion as a starting point to tell stories. Then, he told us the second story about a unit he created called $B B C$ Hacks. There is strong evidence that we are receiving wrong emotions on the internet. He spoke about the investigation of Betsi Grabe, who said that negative news discourages women. The research shows that the $B B C$ is seen as a very negative station by the global public and especially in our global audiences in developing countries. People think that the $\mathrm{BBC}$ has to do with problems and never with solutions. So that's why they created BBC World Hacks. You make short videos and detail half-hour radio stories. They cover everything about food waste, how to talk with children about sex, even applications that can help blind people to see.

The point here is that it's not superficial stories or inspirational porn, I think it's a significant journalistic story, the project is called Solutions focused on journalism. This type of journalism goes hand in hand with investigative journalism telling people what other people have found as a solution and asking if this solution works and journalism goes further. They really want to know that someone is doing something good, but is it really going to work? Then, they make videos and also a radio station like podcasts where the story is written. Mukul Devichand says it's easy to prove that people like it better thanks to statistics, likes, visits and participations. He says that they publish two videos each week and have an average of 5 to 10 million "likes". People really want this kind of journalism, especially on social networks and Facebook. 


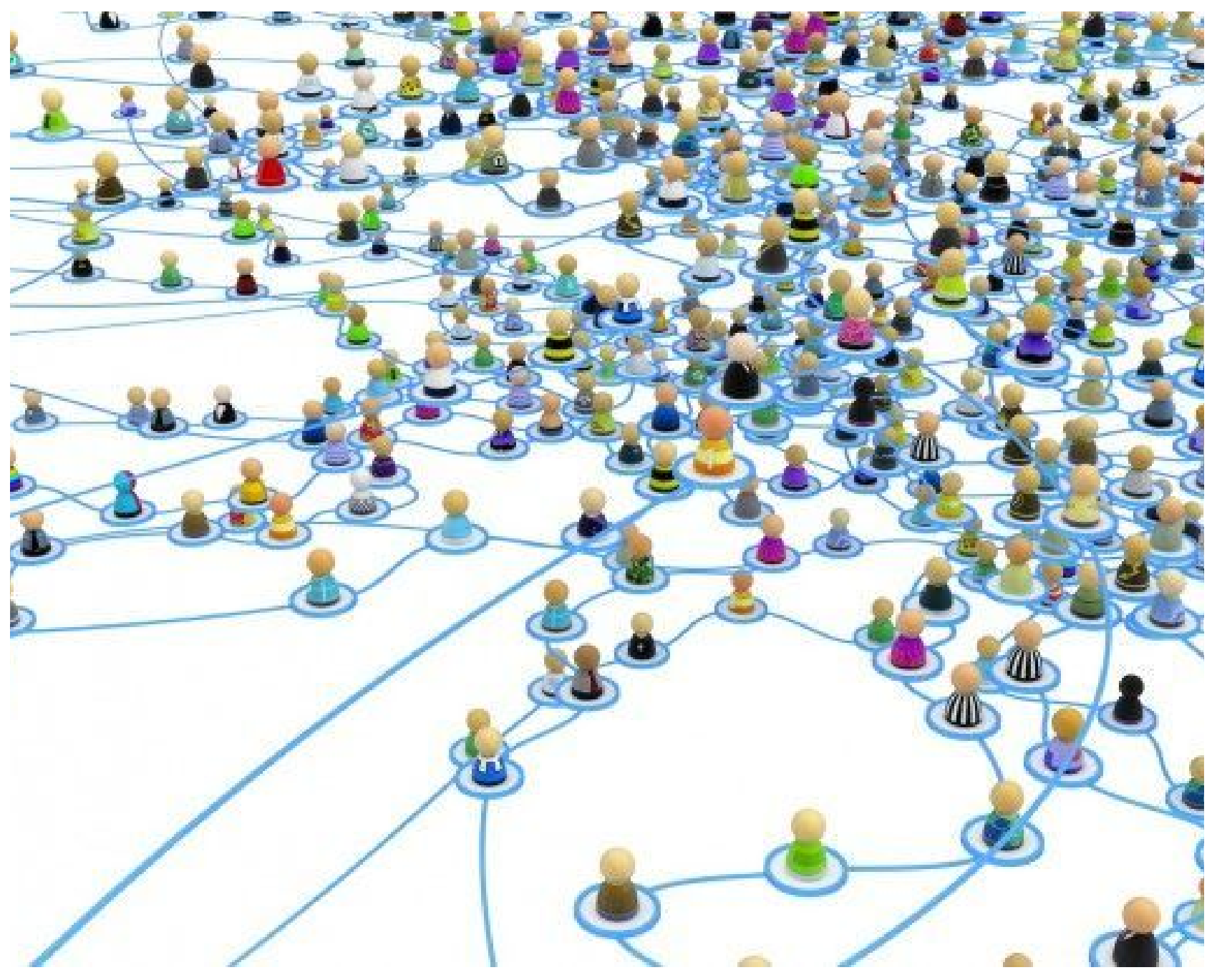

Audiences Grow

It is essential to consider social networks as the new sources of information, always considering the analysis of sources and their ethical redistribution.

There is something important in these stories, how much the story of this person from memory because that goes very well, but eliminates the analysis and research of the solution. They also realized the importance of telling a story, even if there is not as much evidence as a journalism of ideas. So, they created this thread called Think Again.

Mukul Devichand believes that we should not fear social networks. As a journalist, it is useful to remember the principles of our work and then adapt to the media the best we can do. It can not be an extra in social networks, since these are about the algorithms generated by users. They are very difficult for the media because they take away control, but to start we must understand and move forward. So what's next? Artificial intelligence begins to replace the algorithm. Therefore, we need to find a way to attack that too. 
Nelly Valbuena,

Digital Radio "Mujeres Contando" (Colombia)

Back to Index - Versión en español

\section{Conference: "Talk with / about Women: an Urgent Need"}

There are many initiatives of women that try to developin media, whether traditional or digitized. I was going to talk about an initiative born on the radio. It started as a program in NCR, in an alliance of social responsibility of the media. That has a lot of responsibility on the part of the media, I mean they make us believe that they are giving us a space when they only do it as part of their responsibilities, at least in Colombia, Nelly clarified.

This is how the purpose of "Women Counting" began under the dynamic that NCR allowed them. Then, they say that it became a very important space for dialogue, especially when it comes to gender and women's rights throughout the armed conflict in Colombia. This program began in a state medium, but President Uribe, in his first term, closed the radio. Then, they ran out of space, that is, when they decided to go to NCR, but then quickly realized that they had a very good audience, the programs lasted one hour after $5 \mathrm{a}$. M. But on Sundays no one was heard. and the

...This space is made by men and women, men sensibilized and committed to the rights of women and the eradication of violence against women.

question of the public was always, if they are going to do it again at another time. It was then that they decided it was time to have a different space and then they started a digital radio. At first, they started with a program once a week, but finally now they have a 24-hour programming and an online page dedicated to gender and women's rights, problems and discussion.

It is not a space only made by my women because for them in the foundation it is a requirement to include men in the themes of women's rights and prevention of violence against women. This space is made by men and women, men sensitized and committed to the rights of women and the eradication of violence against women. Men who contribute a lot if this struggle for egalitarianism between men and women.

Only as a matter of initiative, Nelly is the director, but it is not something that remains forever, they are always trying to rotate and put different women 
have a woman in charge, because they ask for it, so that, if they have a man in charge, they have to change. It is more, a financing opportunity than a condition. The foundations and the radio try to have a more horizontal relationship.

Nelly stressed that for them it was very important to give a theoretical framework to this project, so it would not only be an exercise in activism, but also journalism, activism and social project to improve the lives of women. they realize that they need theory. They set out to do some research on the meaning of the use of organs, especially the female body. When we talk about female bodies we do not only refer to the body of heterosexual women, but also to these new forms of body intervention to develop a sexual orientation that builds on the stories we hear and the media and are very difficult to understand the body of these other women, since they also have problems to be recognized and accepted in the feminist movement. That is why we work under the gender approach that involves recognizing violence against women produced by the construction of imaginaries and the perpetuation of gender roles in society. That means recognizing other ways of taking on women. They work under some concepts of Foucault, Judith Butler of the bodies of women.

From there, some research has been conducted that allows them to understand and recognize the importance of media that speak about women's problems under a gender approach. The first thing we saw, is that there are some stereotypes that have made the female figure is conditioned by the market. The bodies of women are bodies that the market consumes for their own benefit, they are sold and modified by the means and the needs of the market, they are consumed and discarded. Exactly like what is happening with women's lives. They have discovered that media determines concepts of beauty in women. This beauty scheme is what determines if you can work in media or not.
Journalism has used the body of the woman as a sexualized object to attract more audience. This type of stereotypes are those that normalize violence against women. Either we, the women, are sexist or we are seen as the homelike person. The one that stays in the private life, in the house, the one that does the tasks. They have discovered that women are not a source of journalism, even if there are women more prepared for some issues, men are always chosen as a more reliable source. Another thing they found was how little girls are represented in the media. Girls who are actually represented as women, who wear high heels and dresses, that's what girls grow up watching. In addition, there are no investigations or reports on women's news, they can be about violence or success. Women are not a common content seen in journalism. Not only are women excluded but also other genders and sexual orientations, who are never talked about in the media. Another way to represent violence against women is to justify harassment and criticize women, such as the motive of being a victim.

¿How to talk about violence in the media with a gender approach?

1. Speak from a human point of view.

2. Include women, homosexuals, bisexuals, trans and intersex in their sources.

3. Inform yourself to inform (learn about history, social theory, economics, politics and gender)

4. Check the information that the case and the source give you.

5. Interpret the new sexual realities by looking away from their limitations, morals, religions and politics.

6. Go back to your journalism principles.

7. Opt for the victims. Be careful with revictimization. Do not promise help.

8. Do not blame or questions the victim.

9. Remember the contextualization.

10. Verify the risks and impacts of writing a report.

\#PerDebate17 
Lara Whyte,

Producer and investigative journalist of Vice and Open Democracy (UK)

Back to Index - Versión en español

\section{Keynote Conference: "Challenges in the Coverage of Reproductive Rights and LGBTI Communities"}

Member of Belfast in Northern Ireland, he has had many jobs. Her independent work and her work as editor of commissioner. He showed some of his most important stories as an independent journalist until the moment.

As an independent journalist it is essential to find stories that no one else is covering and this is what led her to work in the research. He spent 7 years working for a commercial news broadcaster in the UK and made many stories in which he had no interest. His first big story was about the girls kidnapped by ISIS in northern Iraq and Syria. All the stories shown on the screen were from people he met on Facebook. First she began to register the testimonies of the girls who were kidnapped by ISIS shortly after it happened in 2014 and 2015. Therefore, she was quite frustrated because the story was not getting the attention it deserved and in 2015 in Europe it was the crisis of refugees and every day there were images of families entering by sea and that is where most of the press concentrated their attention at least for a certain amount of time.

Using open source information collected by the UN, he managed to get only $13 \%$ of people in northern Iraq who entered Europe to be women. And at the moment when that was not really reflected, he decided to make the trip back to Norther Iraq to find out where these women were, where they were going and the conditions they suffered. He did not go to the front in the north of Iraq, he was quite close, but all the other journalists in the region did so, so it is worthless to be an independent professional to offer a story to a newspaper or an announcer, something that can be Get for themselves. If the world's media focuses on one place, it is necessary to look in the opposite direction. Then, he met Nadia and interviewed her and many other women anonymously and when he interviewed her, he quickly realized that he was registering testimonies of war crimes and there was no official body at the time of recording these stories, so He had to have received many advice from psychologists, groups that defend women's rights, so as not to traumatize the victim again.

In particular, many of the girls in this community in the first days that the ISIS captivity was released committed suicide, and that is due to the culture of shame within their own community. Then, at the center of her story, she was very careful to call the survivors and focused her interviews on the story of escaping instead of victimizing them and seeing them as victims in opposition to the survivors. Nadia, for example, her story is that she jumped from one building to another and climbed through a window and over a fence and her survivor story her escape story is actually much more positive for her to tell and detail the methods of torture she experienced. That framing through gender lenses really seemed to have an impact particularly on social networks and it went viral, which is great when you're an independent professional because it's good for your ego and if you translate it you can get more money. 
Then, Nadia is now a UN ambassador, after that article was published she was offered a book that has just been released and she really has a book editor in Ecuador. That is an example of how a story that started on Facebook and if it is a good story can be translated to all media. Through this story, he discovered that there were armies of women who had been captured by ISIS and then joined the fight against ISIS. Therefore, these girls were fighting for revenge and she had a lot of respect, for her motivation and some of these armies also recruited from Europe, so the story "the girl who fled to fight against ISIS" was another story that made very well and now this girl is also writing a book with me.

There is another story of Ebola, which Lara wanted to talk about, about the long-term impact of the disaster seen through gender lenses. During the crisis much predatory behavior was reported. Then, she went to Sierra Leone and discovered an expression "water for water". What that meant was that the girls had to fetch water every day and there was a big public campaign, they had to wash, they had to stay clean, so they were going to get water, but around the water, the men would be there, and they will not be allowed to collect water unless they meet to be raped. Then, these young women were placed in absolutely impossible elections, whether they comply with sexual assault or risk their family against Ebola. When you spoke with them, that was literally the choice they made and, of course, to comply with the sexual assault.

He interviewed a dozen girls who were teenage mothers and that was the true story he got about teen pregnancy, but by the time he got there, he got this other story of why they were pregnant because these predatory sexual assaults They had to endure. In Sierra Leone, according to the law, once she becomes pregnant, she must leave school. Being a teenage mother is an absolute disaster since the school believes that you will be a bad influence for the rest of the students. So, the NGOs that were working in this country, got the government to end this law, so once it gets pregnant, it does not have to leave the school and this piece and another 5 that it did there, were used as part of that . Bell. She would love to say now that the law has changed but it is not, it is only part of a campaign and hopefully it will.

Much of their work is about challenging laws that are patriarchal in their definition and practice. A video is projected that he made for abortion rights in Ireland. Not by the constitution, which is called the 8th Amendment, the life of women is the same value as their unborn child, so abortion is illegal. The presenter is young, and Vice's style is to involve a presenter in a protection, not outside, denouncing him. In social networks, this worked very well with your audience, which is usually under 35 , so we took the audience through the trip through the presenter.

Lara Whyte's work in general talks about women's rights and she has no apology for that. And the reason he can do that is because he traveled very well on social networks. Then, from the point of view of an editor, it receives many clicks and there is an active audience that likes to listen to this kind of stories. She has this kind of young audience that advertisers want, and everyone wants.

Then, Whyte started talking about 50.50. The gender section of Open Democracy, a global platform of independent media that covers gender, sexuality and social justice. She is feminist and feminist believes that men and women should be equal and 50.50 believes in equal participation of men and women in all aspects of public life and the same responsibility with men in our private lives.

This year's research is to track the worldwide backlash against women's rights. The rights of women and the rights of LGBTI people are under threat due to the growing and globalized networks of religious groups, 
and they do so under the guidance of being "pro-family". Whyte showed part of the work he is doing, looking at how these groups are working, and he is looking at them from a global perspective, but his very delicate work is very complicated because these groups are interconnected, and the first line of his battle is in social networks. They have long-term strategic plans offline and often set up this infrastructure of religious organizations.

They started this year in Hungary, attended the world congress of the family summit where hundreds of anti-abortion and anti-LGBT people met to talk about the rights of families and how to protect their rights. When they say family rights, they were very explicit, they meant mother, father and children, so this is the only definition of family they accept. Therefore, they are against sex education, against abortion, against marriage between people of the same sex. They saw their communication strategies and how active they are. They have had some success in organizing and linking with other international groups and that is having a great impact on the ground. And they are making many connections, particularly in Africa, where the UN's attempts to colonize Africa and impose imperialism through the education of women stand up. So, the impact on the ground is very serious, even though the UN's high level seems somewhat distant from what they are really seeing on the ground is what they are investigating. The tone is all about privacy, the right to family and everything sounds very good little is actually very sinister. These are women who die in an unsafe abortion or a birth and it is about having child marriages and child mothers. And then, when they say that it is a war against women, it is a war against progress, it is a war against rights and it is a war against rights.

Lara Whyte showed us an image of one of the main groups they are getting into, it's called Hazte Oir. They have a great impact in the United Kingdom this year, there was a very sad case in which a baby was dying and his family went to the hospital to treat him. This baby was called Charlie and there was a great campaign, mobilizing everything in the United
Kingdom to protect the rights of the family against the State that tries to kill Charlie, which was absolutely false. They started many petitions and obtained millions of signatures, which reviewed these petitions and there were a lot of false signatures. They have many campaigns on social networks where they are mostly very active and what they did was to evaluate some of the hashtags and find out where they were from, so they claimed it was a UK campaign when in fact most of the hashtags came of the United States and strangely Brazil. So, in reality, the minority of them was from the United Kingdom. They continue this struggle and try to change the law, but she believes that it shows the cynicism of this group to take advantage of the pain of a family to express a legal point.

They call themselves the largest social group in LatinAmerica and have been in Ecuador since 2013, and in Peru at this time they are trying to accuse two parliamentarians because they retweeted about rape in the country and considered it offensive. Here in Ecuador they were part of the protest for "do not mess with my children." And they are trying to bring before the courts a gay rights activist who claims that this protection was a hate speech. Therefore, the irony is that they are using design laws to protect the rights to fight against them.

In the United States, similar groups like these are African-American women and what they are doing is using the language of the Black Lives Matter movement to attract AfricanAmerican women who want to exercise their reproductive choices. They are doing that through Facebook, in particular, and through active targeting in a very smart way that will be used mainly by marketing companies. Then, just to say that the piece she showed us was a piece of commentary, they still did a search on Facebook and got an African-American journalist to write the piece. Because they realized that their perspective is 
European, and they want to work on a global and intersectional content. Then, Whyte as an Irish woman will experience a patriarchy different from that of Ecuadorian women.

She just wanted to look for different points of sale where women's problems were being discussed. Therefore, these outlets have been growing in the last 5 years, for the same reasons that stories about women, stories that she showed, are popular, simply because there is an audience that wants them. But, although it is good to have these points of sale, some of them reproduce the same problematic attitude towards women.

There is some good research on who is writing stories, even on women's issues, and it was an interesting statistic that they discovered, so women only write $37 \%$ of reproductive histories, while men write $52 \%$. So that was the coverage of the mainstream media and what they believe shows that half of the pregnancy coverage and reproductive choice has been written by a part of the population that can not get pregnant. And then, they believe that it shows the irony of the media to change and for men to return to their lane and make us ours and reduce speed a little.

There are many news pages about women, but where are the real feminist researches? Therefore, they have identified this need that is what they are trying to do at the moment. Often, women are in the forefront throughout the world, but their voices are lacking in many investigations. Women's human rights defenders are being murdered around the world, yet very little research analyzing why human rights defenders are being killed is seen from a gender perspective. And so, an example of this is that we examine land rights, women who protest are often attacked twice, once because they are there and, secondly, as a way of attacking men, so that they can be object of sexual assault as a way to get it.

An article about women on the front lines of the front of the environment is a very simple article, but your audience loved what they are looking for doing a job more like that. Since they began this follow-up in the campaign of violent reactions, they had a very good response from their audience, which fell and shows interest in this type of feminist research.

Therefore, your page has been active since May, the page has risen by $37 \%$ and, nevertheless, they have maintained a very long time that people are spending on the page. They are a model of independentmedia, which means that all information is open, so it can be reused in your own research and can also be translated into different languages.

Finally, Lara Whyte notes that the groups that are investigating representa threat to the rights of all women and many men, but in places where reproductive rights are not protected, the risks are much greater, so as a feminist, journalist of Research, your goal in this project is to investigate how this happens on the ground and realize that you do not have enough links throughout Latin America. Therefore, they want to explain how these groups work at local, regional and national level and the impact they are having; They want to pierce the false narrative and use this information to help women resist despite these threats. He invited to visit his page, use the information and join investigation.

\#PerDebate17

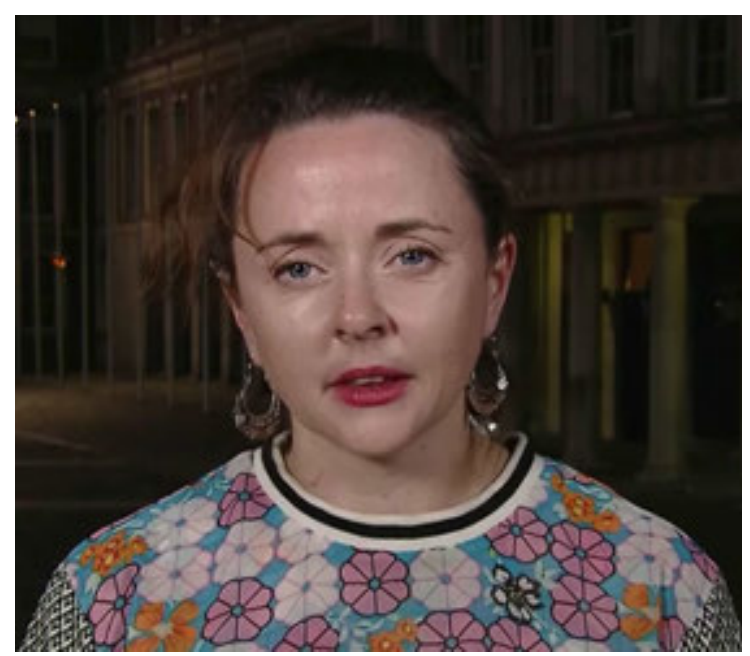




\section{Forum,}

Participants: Cécile Mégie, Lara Whyte, Verónica Larrea, María Dolores Miño

Moderator: Ivonne Gaibor

Back to Index - Versión en español

\section{"Female Leadership in the Media"}

Ivonne Gaibor: This is a great issue in Ecuador. Rvisé a tweet published by the new head of the public media, Andrés Michelena, made reference to a meeting he had with the Minister of Industries. The relevant thing about that tweet was the image with only one woman there, who was Minister of Industries. It called my attention. Later, I thought that in the newspapers where I worked years ago, there are two women editors of section. And it's the same in other media. In El Comercio only $20 \%$ of publishers are women. And I even think that it is a problem that is repeated throughout the world, but the important thing here, in Ecuador, is to start talking about this. I did not find too much information about the situation of women in chief media in Ecuador, so I think it is time to start talking about this topic here. The first question is, ¿what are the difficulties encountered by women journalists in accessing the main positions and leadership in the media?

Lara Whyte: There are many reasons. Sexism is key. There are many women of my age in the media that when we are a little older it is difficult to look at the directors because of the responsibilities. They gave up, you know, family responsibilities take over and change, and they give up.

Verónica Larrea: Yes I agree. Unfortunately, and this is not only in the media but in many other businesses, public and private. I feel there is something wrong with the meaning of gender egalitarianism. Many people say that "women have the same rights as men because now they can work, so any woman has the same possibility of occupying a job as a man".

When a woman wants to get a job, we can see that it is not true. Is there a real possibility for women to take aleadership position? Many times when women are 30 years old, our lives change, we have to divide our responsabilities.

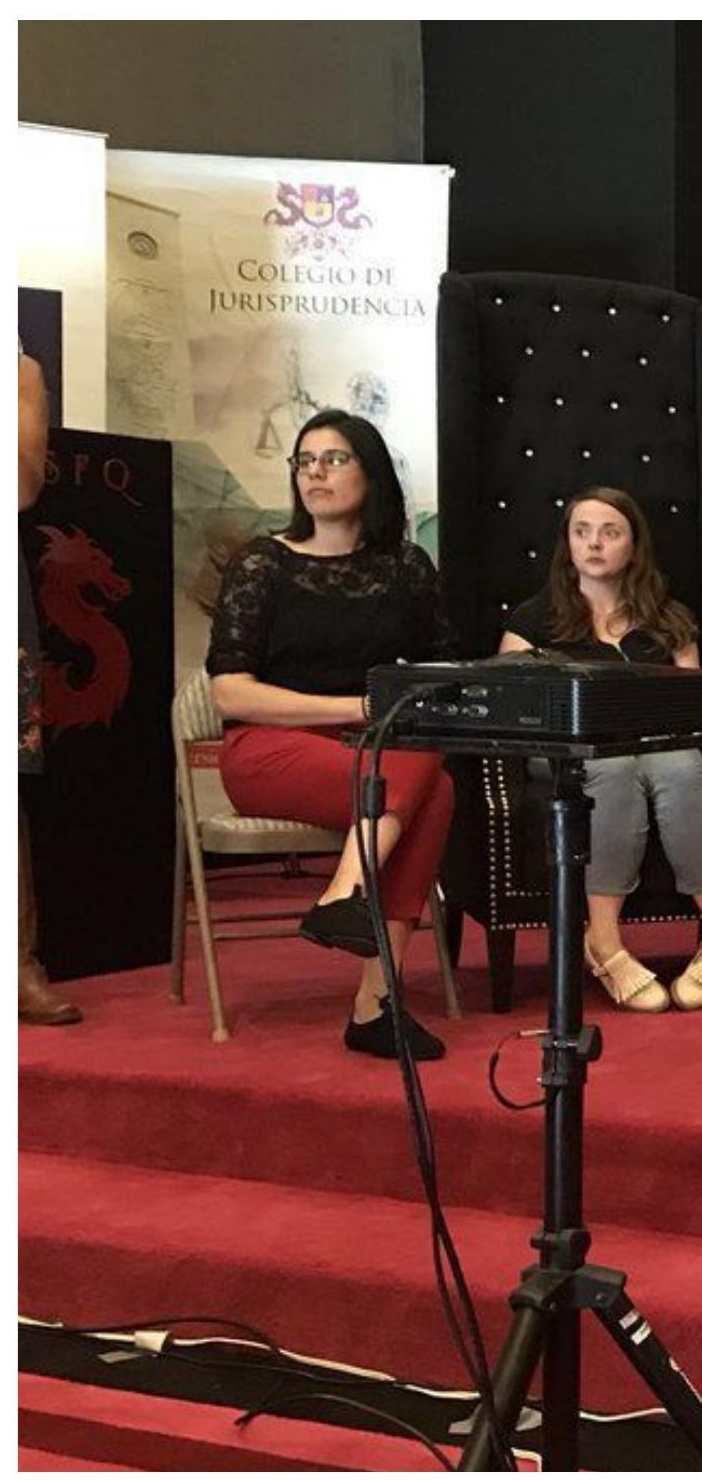




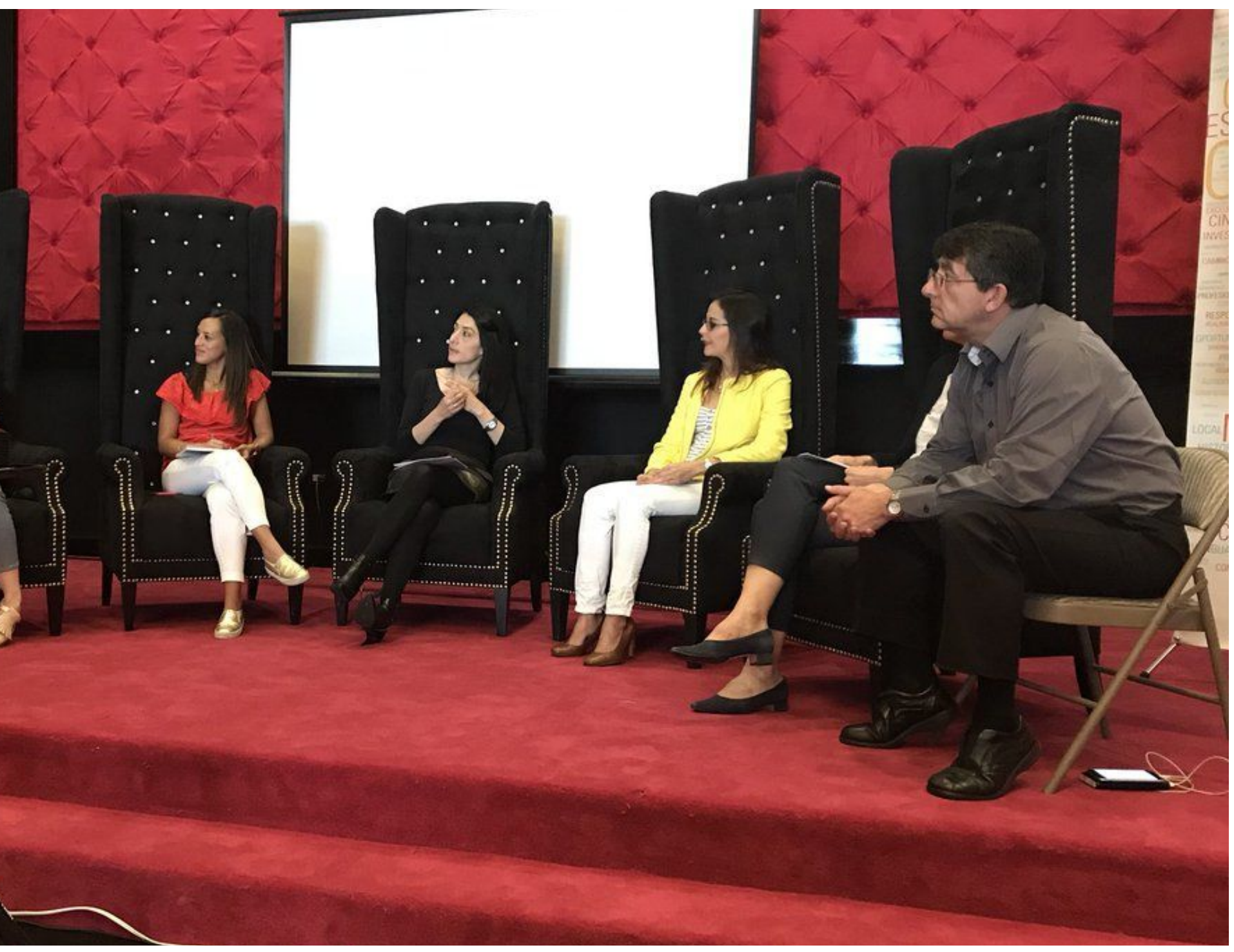


They are crucial moments for equality in every way. Female leadership continues to expand to different circles and social work, so its performance in current media is essential for the construction of a more just society.

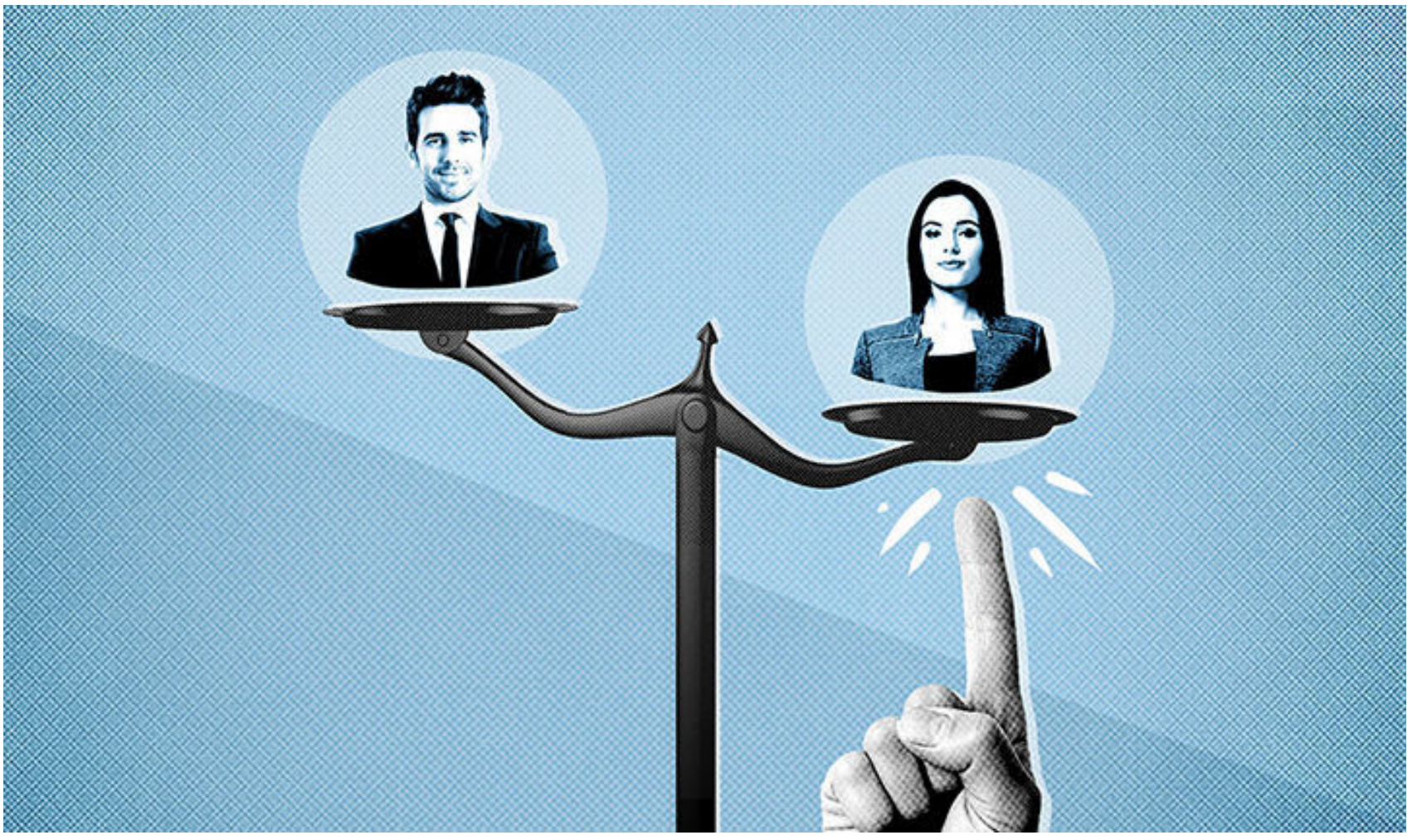

and if these means do not adapt the way of working to allow women to have their own responsibilities, there is no other way than to leave a job. So, for me, the question is how do we adapt the jobs so that they are compatible with the responsibilities of the women, since it is the family, the couple and, ¿why not the recreation time as well?

María Dolores Miño: Well, Ivonne already exposed a reality. Women do not occupy the main positions. The initiative in which I work, Chicas Poderosas, is looking for this to happen. There are many difficulties and I believe that all part of society. This patriarchal society that has put the work of women in the background. Men are the provider and women have to be on the side. I think that premise has to change and has begun to change. Because women are as capable as men, however, we have not given ourselves the opportunity.
It is necessary to have the mentality that we can do it and we can value ourselves to make society understand that this can be changed. So, the difficulties are many. A lot of male domain problems. Men do not respect women in charge. So, the change comes from valuing ourselves to change our reality.

Cécile Mégie: I'm very fortunate. I work in a country and in a medium where women arrived very high. We still have to make progress, but there are already things done. I spoke with Betsi and I told her that the French are good figures in that plan. Women must have confidence in the fact that they can do this in the administration of a press room with some 415 people and, sometimes, when I want to promote a woman, not because she is a woman, but because she has good skills and the good profile to a new position. I have to convince her that it is possible for her and make her trust that she will achieve it, even 
if she has small children, even if she has a family life that she wants to support, it is normal, so I think women have to say, okay, I tried. And we as a manager, we have to manage it in the way it does the work. But as a manager I am very careful about how the woman develops.

Nowadays, nobody can accept that, in an image, whatever the subject, there are only men. When you go to social networks you see sometimes, and you have to be very sensitive to this fact. $51 \%$ of humanity are women, so they have to appear everywhere, whatever the subject.

Cécile Mégie: I'm in this newsroom for 25 years and it was not that difficult. I know that the CEO of FRI is a feminist, is a militant and has three directors to name and wishes to appoint women and men. Therefore, it is an entrance from children and for years only continue to happen. In addition, I also felt that, from the point of view of other women, I felt the same rivalry. Is awesome. We have to change that, and we are here to change it. It's time to do it and being here debating about these problems is already a step.

María Dolores Miño: Yes. I am not a journalist, I am a lawyer, but I have worked very closely with the media and I really enjoy writing some opinion columns for some newspapers. My feeling has been that women have a place as long as our opinions do not conflict with what men in chief think. In Ecuador, I see that many organizations, media and foundations have a very strong link between the boss and the organizations, so when you question an institution it is the same as questioning the boss and that generates conflicts.

\section{...I am not a journalist, I am a lawyer, but I have worked very closely with the media and I really enjoy writing some opinion columns for some newspapers. My feeling has been that women have a place as long as our opinions do not conflict with what men in chief think.}

that they impose, there are women at the top of the radio FP. Before being the director of FRI, I managed the economy service, and one day I realized that I only had women in my service, I communicate with the director, I say "please, give me men in the service, it is not suitable work like that. "I'm sure we have to work together. We have to live together, and we have to work together. Balance is necessary.

Verónica Larrea: The case that Cécile exhibited is very rare in Ecuador. We can never imagine that something like this will happen, but it is good to know that in European countries these things are already happening. In the personal case, for many years I worked in a newsroom where it was easy to notice the differences between men and women. I felt this relationship of power that comes over society and a social imaginary. The things we learn
It has been almostayear since Istopped writing a column in a newspaper because I was living a situation like that. Women journalists, about 32 and 36 years old, fought with me against this newspaper because we did not agree on an editorial decision. They treated us like little girls that did not make sense. So, after that, my perception is that there is no habit of questioning male leadership. After this, all I asked with my other colleagues is to what extent the gender difference is still present and the fear that some women sometimes have when questioning male dominance.

It is common to think that women feel that they are not prepared to assume some leadership roles in society. I feel that I question my work and my abilities and then I see men with less knowledge than $I$ do the 
work because they have a complete society that supports them. And sometimes even, the women themselves are in charge of diminishing their own sex. If you, as a woman, begin to have a public profile, you can not immediately do other things or you will not take care of others, and the guilt that some women feel is that which causes women to abandon important leadership positions. Male domination is not only that men take control but women who repeat these patterns of domination.

Ivonne Gaibor: Lara please, ¿how was your working relationship with men?

Lara Whyte: Fairly good in general, to be honest. I think the sexism that you get in the media in the United Kingdom is much more subtle. And there are some problems in particular as a young journalist to do many more things about celebrities or silly things of royalty, but I think it's much more subtle to be honest. Within the organizations with which I worked, there has been at least one woman in top management who is a nice thing to see as a mentor. And the best thing about being autonomous is that you do not have to deal with the internal drama, so you just have to write your story and that's it.

Ivonne Gaibor: Lara, ¿have you felt that in a leadership position you have had to highlight your skills and have you felt questioned in any of these roles?

Lara Whyte:Yes, absolutely, but I think the first person is usually me. Am I good enough to do this? I also found that when I am an editor, I would never like to talk, when I was writing, I would never have spoken to an editor in the same way that people have spoken to me. You are editing my editions. And I do not know if it's because I'm paranoid, because I'm a woman, but I would never have treated someone that way.

María Dolores Miño: Yes, I feel that as women we assume we can not. And l've also found myself in many spaces where they have not noticed me. I feel that in Latin societies we have this presumption of being less capable, which also helps us to be more precise in what we speak, be more willing to do anything, so that our work becomes richer and finally this quality is seen and it has a positive effect on our experience.

Verónica Larrea:I have feltit. Starting inoneself to convince ourselves that we are capable of doing it and to convince the rest of the people that we can do it. Sometimes, we are confronted in situations where we have a dominant male figure that does not allow you to question. It is a great struggle to convince yourself and then convince your team and the people that you are capable and, in general, everyone that is important.

Cécile Mégie: Yes, I said that not everything is made in France and this type of question is immobile, and even in my company. I should point out that perhaps in a meeting with women and men it is very common for men to take the speech more easily than we, even I, and when you lead this meeting you have to be very aware of who is taking the speech and who is talking and when, and sometimes there are women who have a good idea but who say very quietly. And the men right behind her take the idea and say it stronger, so you must recognize who said the good idea and say "thank you, miss."

And the second is maybe in salaries, income. I think the studies are about 20 or $30 \%$ in the same job between men and women on average. In RFI it's not that high, it's better than average, but a few weeks ago I named a woman right behind me, the assistant director, and I had to fight with the CEO to tell her that I wanted her to be paid as the man she I was replacing. And it was not so easy, so I still think we have so much progress to make and we still have to convince women maybe in the work I'm doing now, my responsibility is to look at this all the time and not let any inequality define them. 
Ivonne Gaibor: Yes, exactly the issue of the nest I wanted to talk about, wages. We have a big difference in salaries and we can talk about what is happening in France and Ecuador. We are living a great salary difference.

Verónica Larrea: Exactly what is being said, Cécile, about reproducing in the country, would like to understand why women are capable of doing the same work and receiving a lower salary. Maybe because women can be mothers and I lack many. It's something that I've really tried to understand, but there's simply no answer or reason.

María Dolores Miño: Women still see themselves as a commercial weakness. Something that is not worth investing since in the end it will go away. If you are a weakness for the business because eventually you will be a mother. The next action is not to hire women and for the expulsion, media, would lose this feminine voice and the point of view that enriches its multimedia content. So, the question is really, how do l adapt my structure in order to work with the new roles of men and women, because women are not only the ones who care and men are not only the guardians. This calls us to ask ourselves what to do to change this structure and adopt it for the 21 st century.

Lara Whyte: I think it's a bit different when you work on your own, but not because of the key things that keep women from asking for more money. And also, as an editor when someone sends me a message, they do not ask for a lot of money, I have a budget and I think "yes, yes, I can use that money elsewhere". So, in terms of getting more than my salary, I almost dare to ask for it and I give double the salary and I did it because I did not need the job, so it's a really good exercise, and now I only increase my salary.

Ivonne Gaibor: We have to start to finish, but I really do not want to leave behind a question we had there, that is, well, Lara, Cécile and Vero have more experience in content production ¿How do you think the production of content in the news changes with a woman in charge?

Lara Whyte: I think it makes it easier for a woman who wants to see. We are thinking about audience participation, women are bored seeing the old representations of themselves. Therefore, it really improves your ability to tell stories when a woman participates in each stage, working with men. I do not think it changes completely but I think it only adds more texture and a lot more depth in the story.

Verónica Larrea: Speaking of the news content would not have to change much if we are responsible and make the report. But as women, who are a bit more retailer, we can have different points of view and we can give that report a fresh air. In terms of opinion, I think it's a bit difficult in the case because women have a different view of the world. That creates diversity and debate. But, what I really think changes in the content are the people that are reflected in the news. And I was looking at some very interesting statistics from UN women and I see that women who appear on television are victims or celebrities. But women political leaders are not being part of that content. And that, in fact, is an interesting topic and that leads us to ask ourselves if we are part of society, ¿why are we not other things than victims or victims?

Cécile Mégie: We must take care, women and men, that the discourse is not a sexual discourse. Women should not be just victims or witnesses and in the French media the media authorities, the regulators, require us to record the statistics of when the women spoke. And we have to have special skills to look for female experts. In RFI, I have to give twice a year the statistics of how much the experts in my programs spoke. And I have been given objectives and if I do not fulfill this objective I will earn less. Therefore, this is a political company and I, and the Man Director 
of RFI 24 hours has to do his job too. But it is not just about money, but we have to give a great impact and information to our collaborator, the discourse of women as well as the discourse of experts and not just as a victim or witness.

But to be honest, what is quite difficult is that it has to do something to do with the way in which our society is hoisted of organs, just an example. I have a health program that was attended by many doctors and specialists, and the producer of this program who is a woman. I was sure I would have good statistics on this program and then I counted them and had very bad statistics. And that was not his fault, I mean that all the responsible people in hospitals and health teachers are men. So, if she wants $s$ to have women as experts she has to understand this problem and try to have younger women maybe, not so big in responsibility, but she has to be very willing in this. And I think it's not just a statistical problem, it's a logistics problem of what we're doing and how we can do better first.

Public: My questions range from ¿how gender affects when writing opinion columns on certain topics, such as abortion? Sometimes society thinks that as women we have to be against abortion and many times we see confronting this society ¿How to write this being women? And ¿how, as women, do you face this?

María Dolores Miño: In the newspaper I used to work, something very funny happened to me. When I started writing or my columns began to read more, I wrote a lot about issues such as freedom of expression or democracy, etc. and the response from the audience, men in particular, was very positive and he wrote me about how well he was doing. After that, when I wrote some columns on gender issues such as abortion, equality and violence against women. The response of everyone was negative. Writing about gender equality issues is sometimes seen as hysteria.

¿What can we do? I think the only thing we can do is keep writing. Write from a legal point of view and make the audience and the opinion of readers get used to this topic because most of the time they are not used to reading things like this, that is why they react. If we continue writing about this, we can make the public get used to it and understand it as a public discourse.

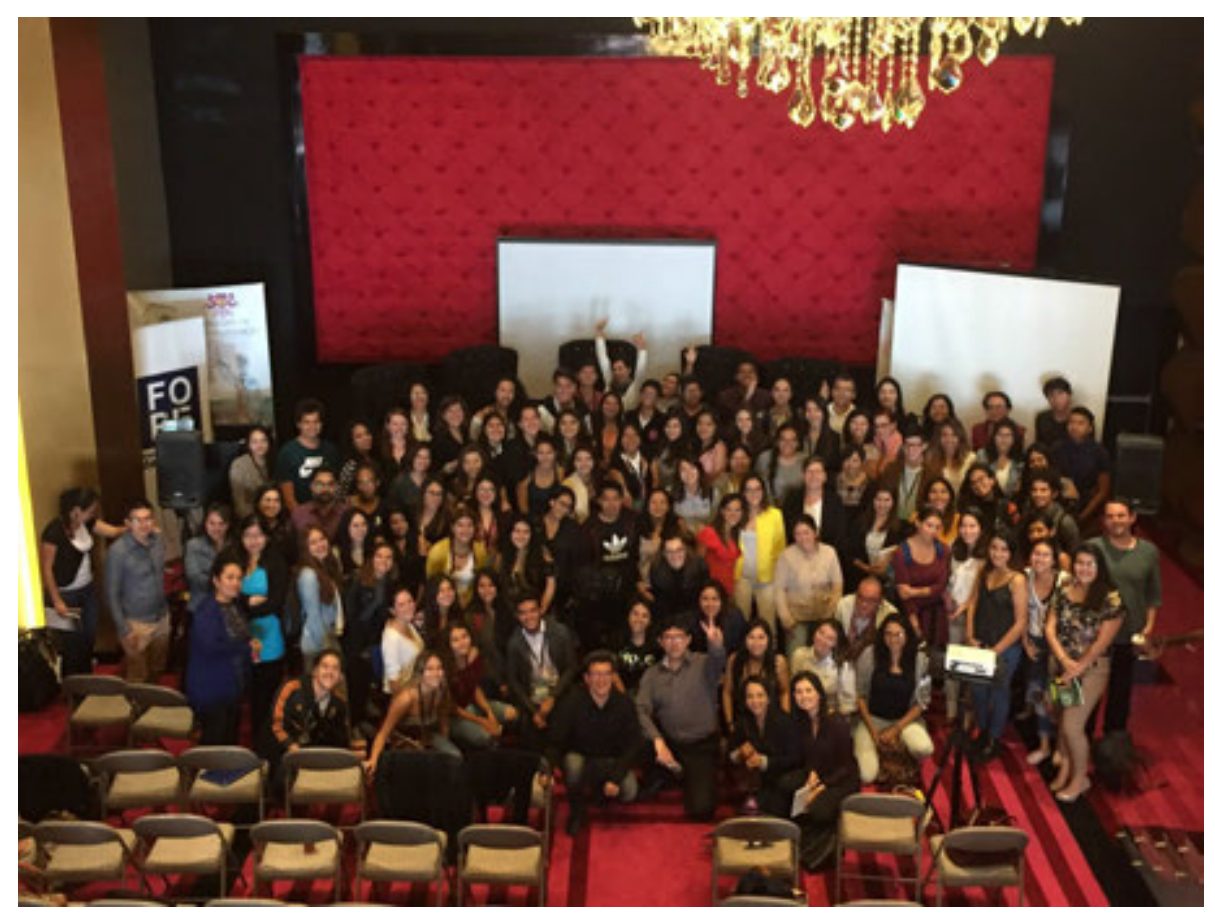


( Universidad San Francisco de Quito - Diego de Robles y Vía Interoceánica

@ https://usfqperiodismo.com/perdebate

f /PeriodismoMultimedios

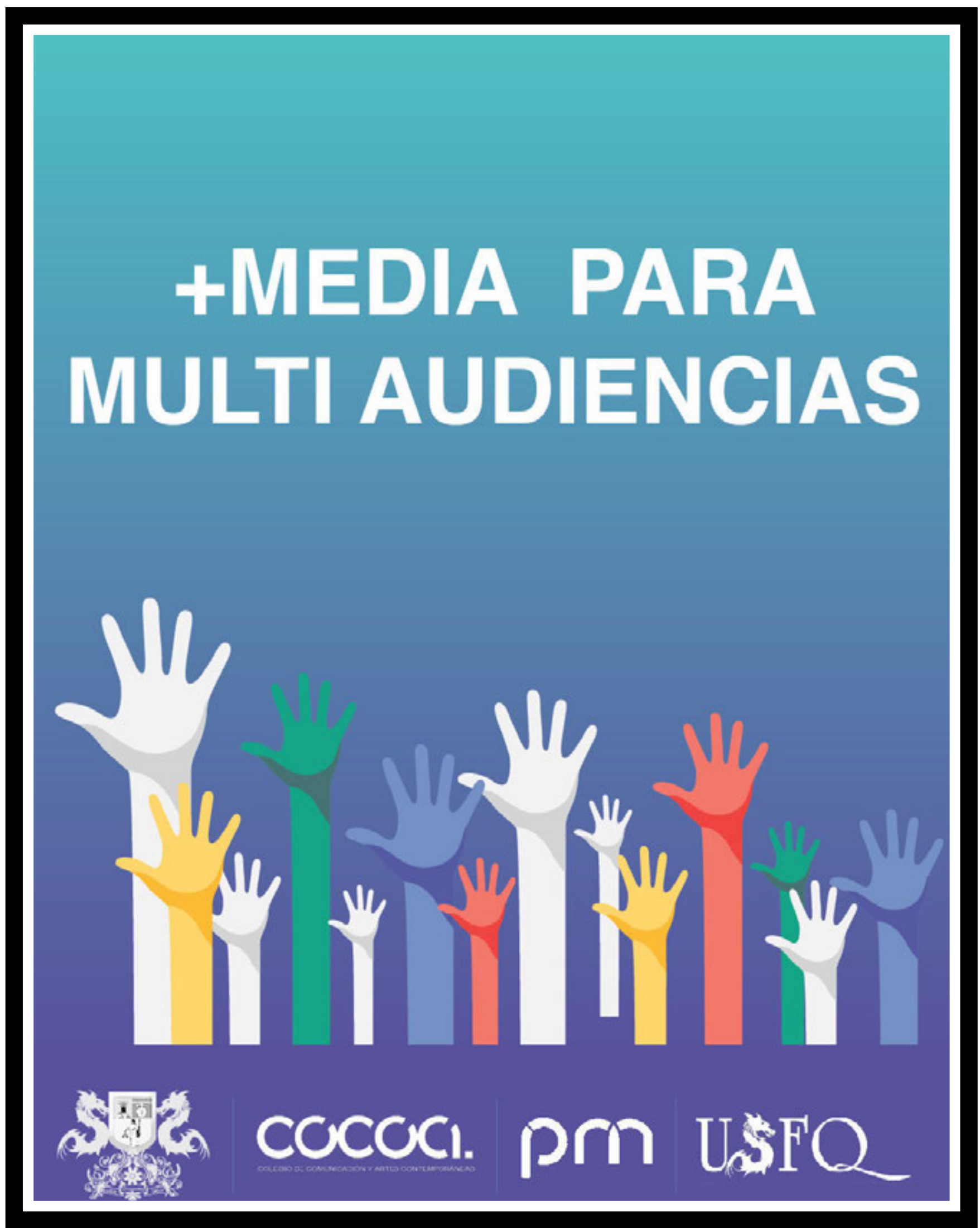

